DOE/EIA-0573(87-94)

Distribution Category UC-950

\title{
Emissions of Greenhouse Gases in the United States \\ 1987-1994
}

\section{October 1995}

\author{
Energy Information Administration \\ Office of Integrated Analysis and Forecasting \\ U.S. Department of Energy \\ Washington, DC 20585
}

This report was prepared by the Energy Information Administration, the independent statistical and analytical agency within the Department of Energy. The information contained herein should not be construed as advocating or reflecting any policy position of the Department of Energy or of any other organization.

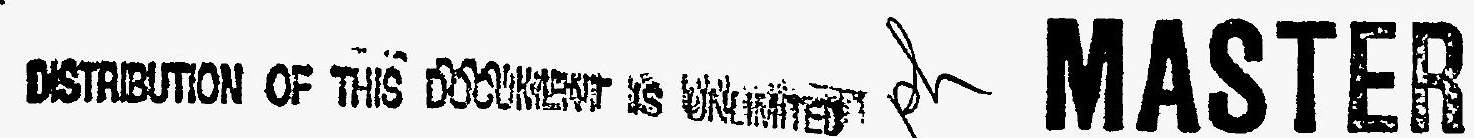




\section{Contacts}

This report, Emissions of Greenhouse Gases in the United States 1987-1994, was prepared under the general direction of Mary J. Hutzler, Director of the Office of Integrated Analysis and Forecasting, Energy Information Administration. General questions concerning the content of this report may be referred to Arthur $\mathrm{T}$. Andersen, Director of the Energy Demand and Integration Division (202/586-1441).
Specific technical information concerning the content of the report may be obtained from Arthur Rypinski (202/ 586-8425, e-mail arypinsk@eia.doe.gov). This report was written by Arthur Rypinski (Executive Summary and Chapter 1), Louise Guey-Lee (Chapter 2), Michael Mondshine (Chapter 3), Karen Bauer (Chapters 4 and 6), Neal Miller (Chapter 5), and Kenneth Pruitt (Chapter 7). 


\section{DISCLAIMER}

This report was prepared as an account of work sponsored by an agency of the United States Government. Neither the United States Government nor any agency thereof, nor any of their employees, make any warranty, express or implied, or assumes any legal liability or responsibility for the accuracy, completeness, or usefulness of any information, apparatus, product, or process disclosed, or represents that its use would not infringe privately owned rights. Reference herein to any specific commercial product, process, or service by trade name, trademark, manufacturer, or otherwise does not necessarily constitute or imply its endorsement, recommendation, or favoring by the United States Government or any agency thereof. The views and opinions of authors expressed herein do not necessarily state or reflect those of the United States Government or any agency thereof. 


\section{DISCLAIMER}

Portions of this document may be illegible in electronic image products. Images are produced from the best available original document. 


\section{Preface}

Title XVI, Section 1605(a) of the Energy Policy Act of 1992 (enacted October 24, 1992) provides:

Not later than one year after the date of the enactment of this Act, the Secretary, through the Energy Information Administration, shall develop, based on data available to, and obtained by, the Energy Information Administration, an inventory of the national aggregate emissions of each greenhouse gas for each calendar year of the baseline period of 1987 through 1990. The Administrator of the Energy Information
Administration shall annually update and analyze such inventory using available data. This subsection does not provide any new data collection authority.

The first report in this series, Emissions of Greenhouse Gases 1985-1990, was published in September 1993. This report-the third annual report, as required by lawpresents the Energy Information Administration's latest estimates of emissions for carbon dioxide, methane, nitrous oxide, and other greenhouse gases. 


\section{Contents}

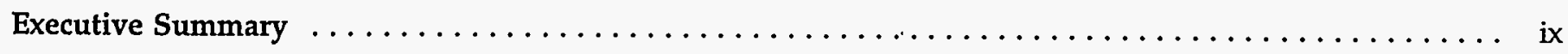

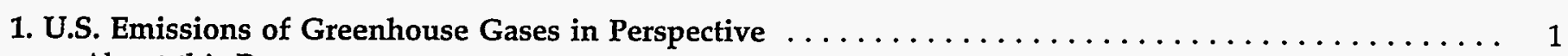

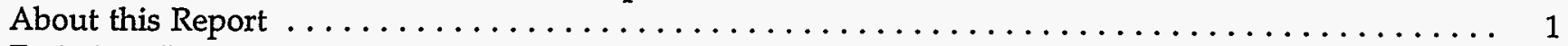

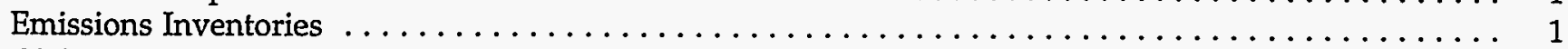

Global Climate Change and the Greenhouse Effect $\ldots \ldots \ldots \ldots \ldots \ldots \ldots \ldots \ldots \ldots \ldots \ldots \ldots \ldots \ldots$

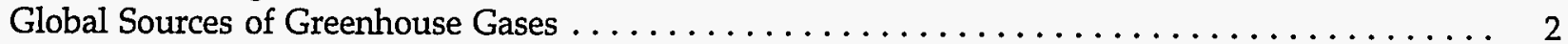

Relative Forcing Effects of Various Gases $\ldots \ldots \ldots \ldots \ldots \ldots \ldots \ldots \ldots \ldots \ldots \ldots \ldots \ldots \ldots$

Recent Developments $\ldots \ldots \ldots \ldots \ldots \ldots \ldots \ldots \ldots \ldots \ldots \ldots \ldots \ldots \ldots \ldots \ldots \ldots 6$

Changing Growth in Atmospheric Concentrations $\ldots \ldots \ldots \ldots \ldots \ldots \ldots \ldots \ldots \ldots \ldots$

Global Climate Change Policy Developments $\ldots \ldots \ldots \ldots \ldots \ldots \ldots \ldots \ldots \ldots \ldots \ldots$

U.S. Emissions in an International Perspective $\ldots \ldots \ldots \ldots \ldots \ldots \ldots \ldots \ldots \ldots \ldots \ldots$

2. Carbon Dioxide Emissions $\ldots \ldots \ldots \ldots \ldots \ldots \ldots \ldots \ldots \ldots \ldots \ldots \ldots \ldots \ldots \ldots \ldots \ldots \ldots \ldots \ldots \ldots$

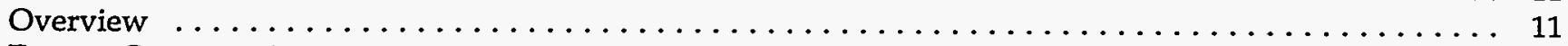

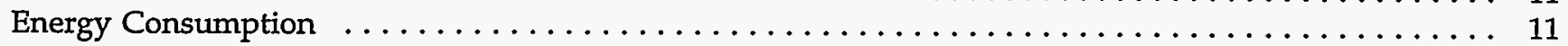

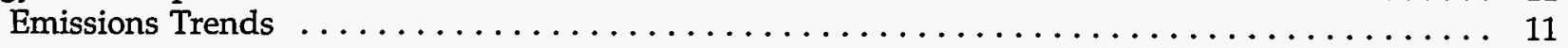

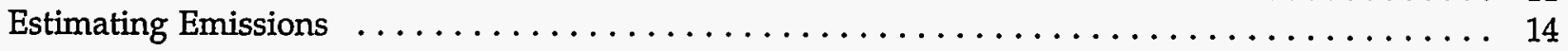

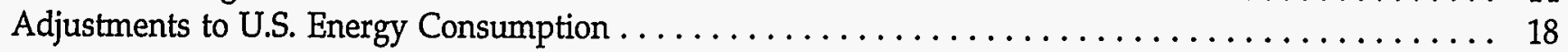

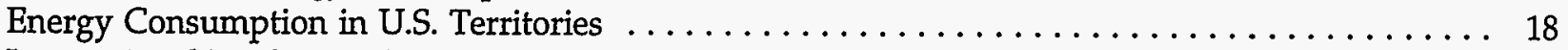

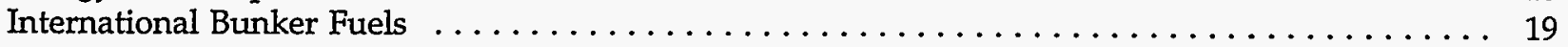

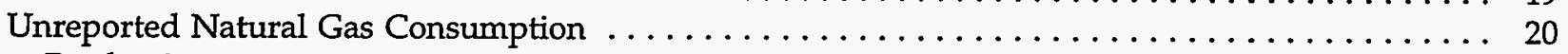

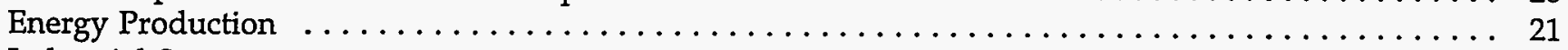

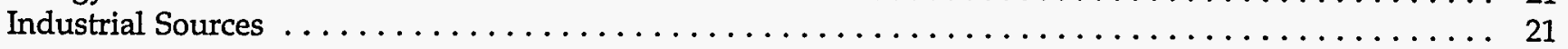

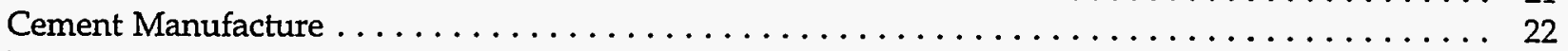

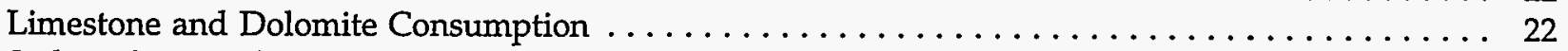

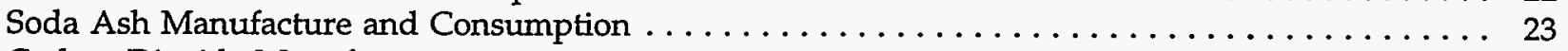

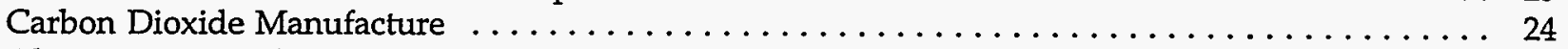

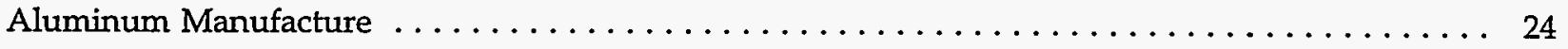

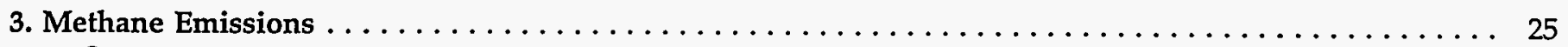

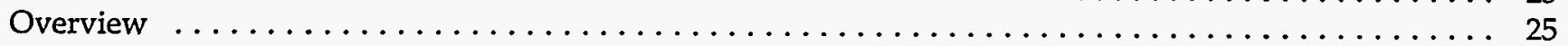

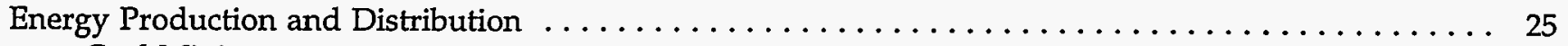

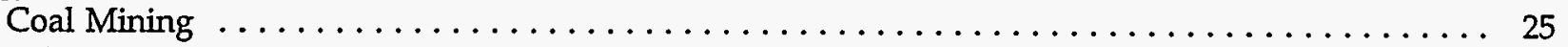

Oil and Gas Production, Processing, and Distribution . . . . . . . . . . . . . . . 29

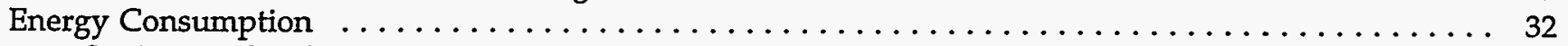

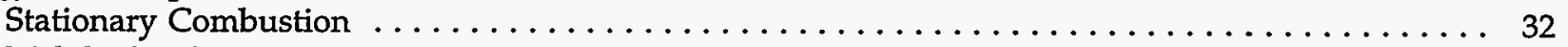

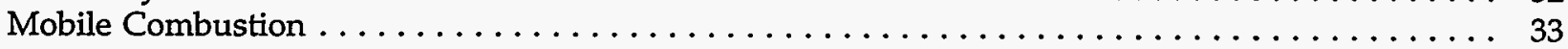

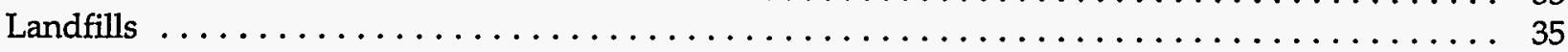

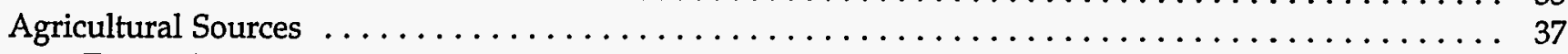

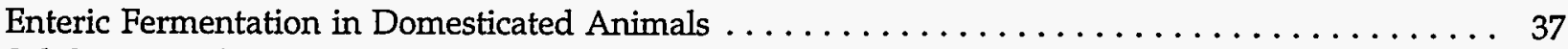

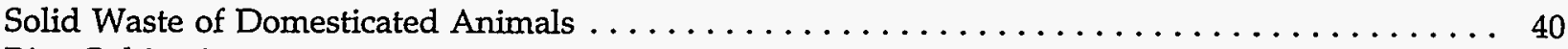

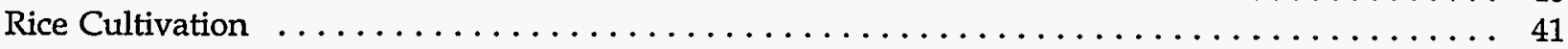

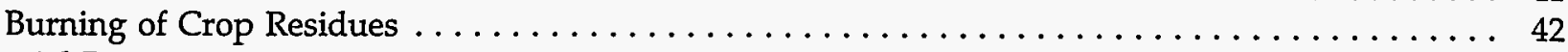

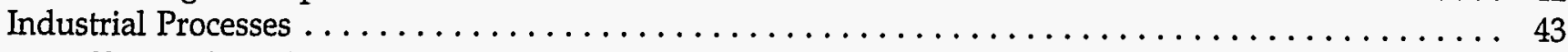

Chemical Production $\ldots \ldots \ldots \ldots \ldots \ldots \ldots \ldots \ldots \ldots \ldots \ldots \ldots \ldots \ldots \ldots \ldots \ldots \ldots \ldots \ldots$

Iron and Steel Production $\ldots \ldots \ldots \ldots \ldots \ldots \ldots \ldots \ldots \ldots \ldots \ldots \ldots \ldots \ldots \ldots \ldots \ldots$ 


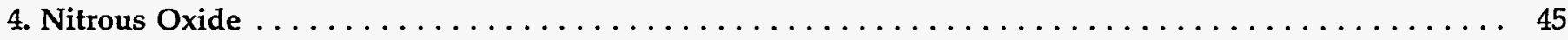

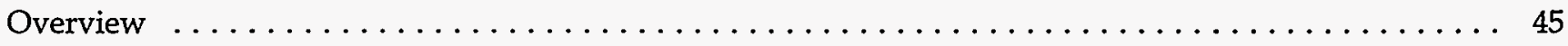

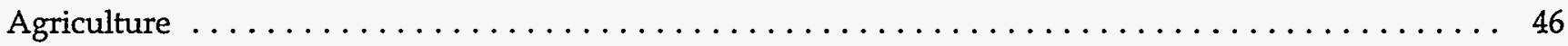

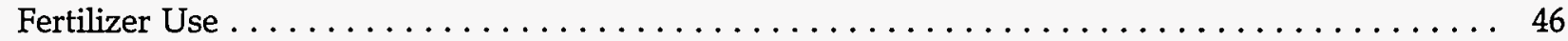

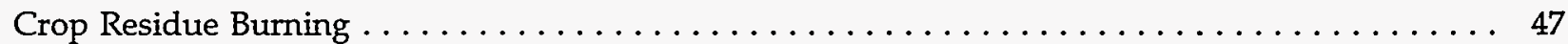

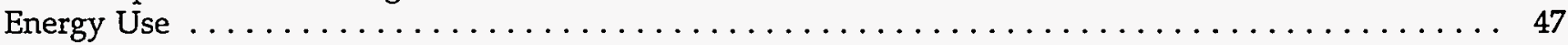

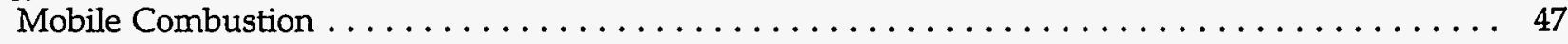

Stationary Combustion $\ldots \ldots \ldots \ldots \ldots \ldots \ldots \ldots \ldots \ldots \ldots \ldots \ldots \ldots \ldots \ldots \ldots \ldots \ldots$

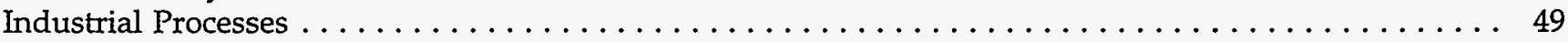

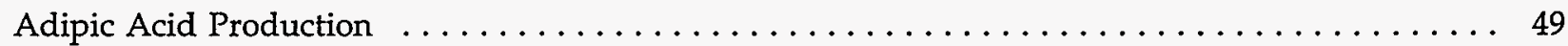

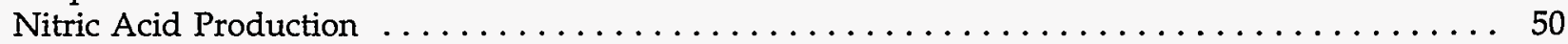

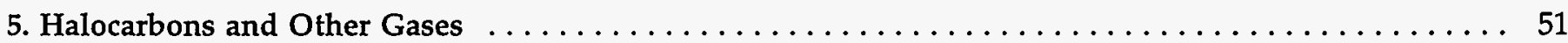

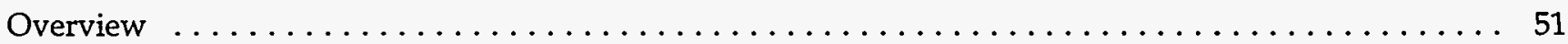

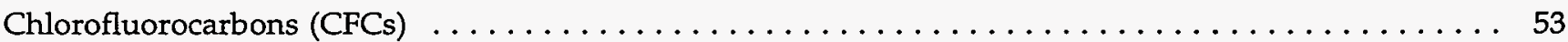

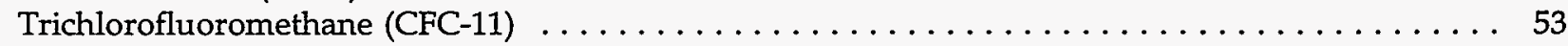

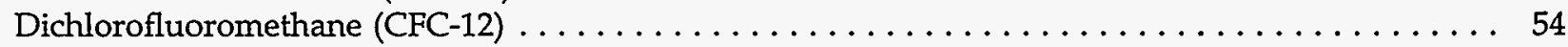

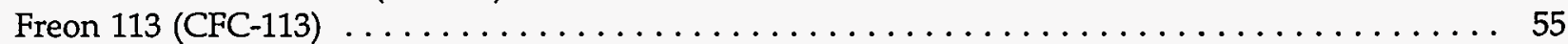

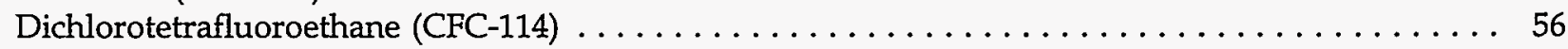

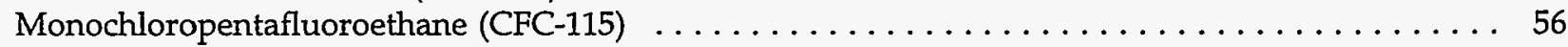

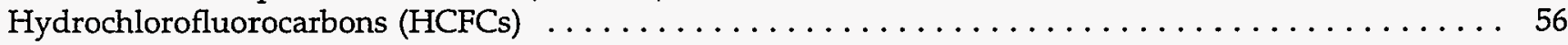

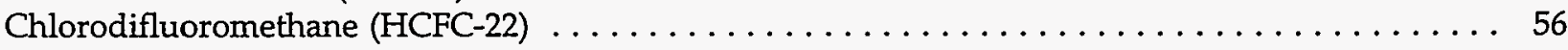

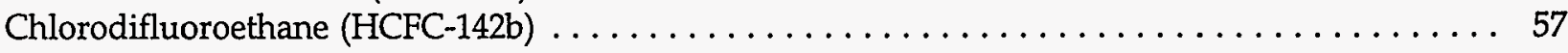

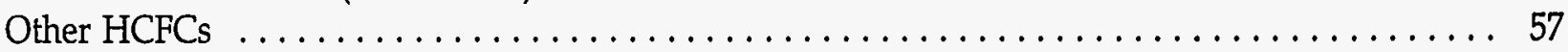

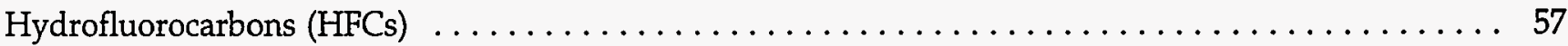

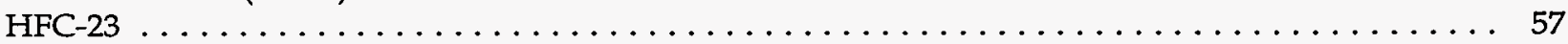

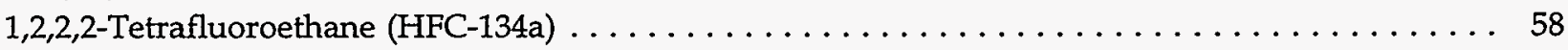

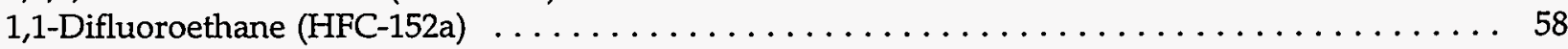

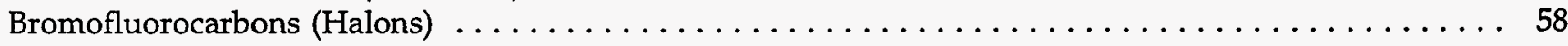

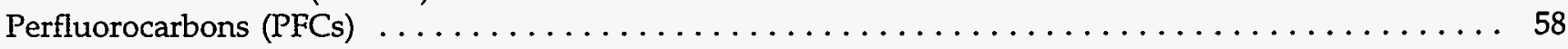

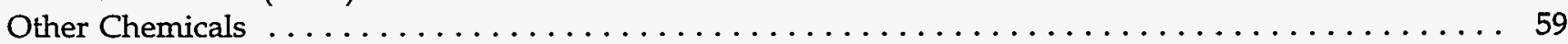

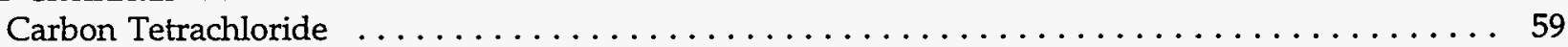

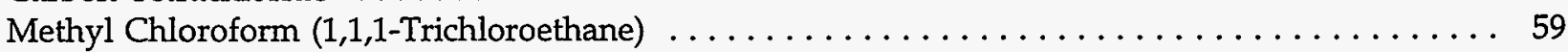

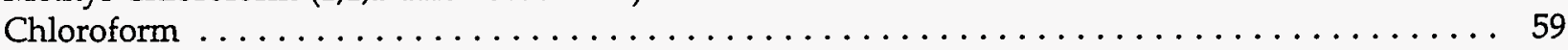

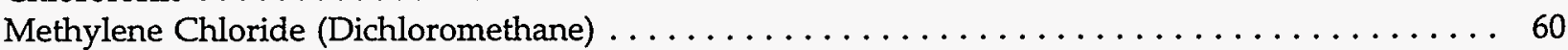

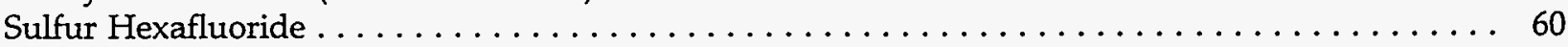

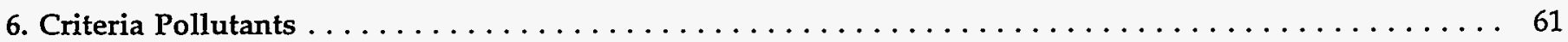

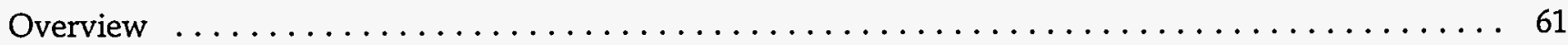

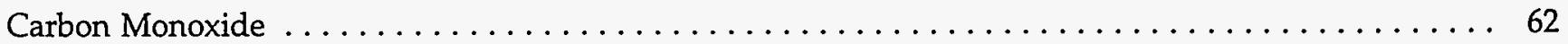

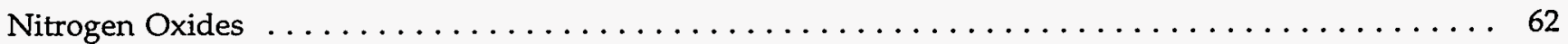

Nonmethane Volatile Organic Compounds . . . . . . . . . . . . . . . . . . . 62

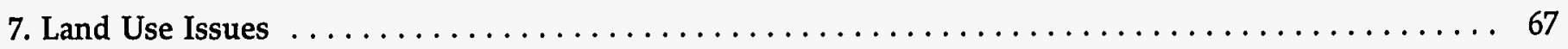

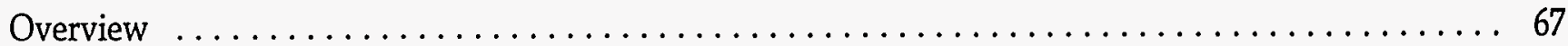

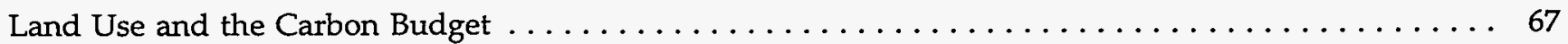

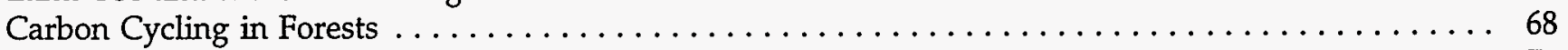

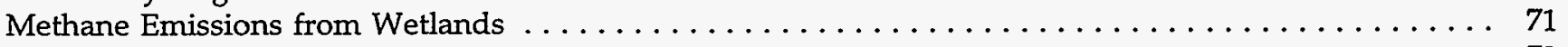

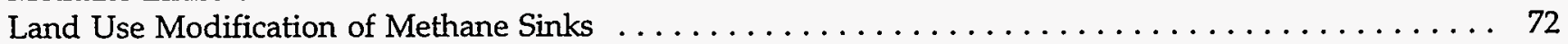

Nitrous Oxide Emissions from Land Use Changes $\ldots \ldots \ldots \ldots \ldots \ldots \ldots \ldots \ldots \ldots \ldots \ldots \ldots$ 
Appendices

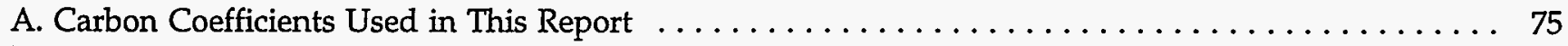

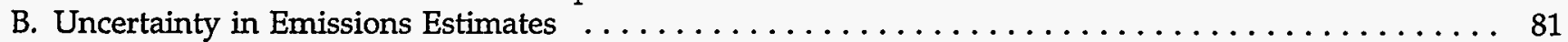

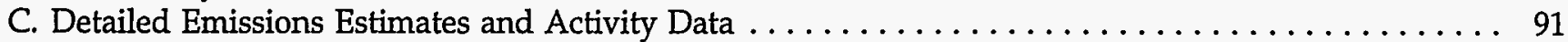

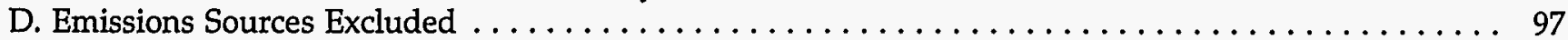

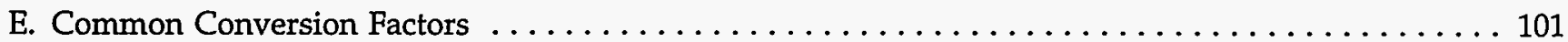

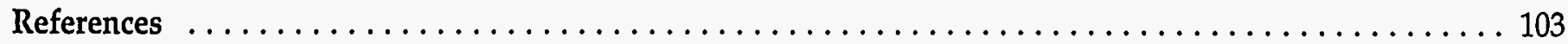

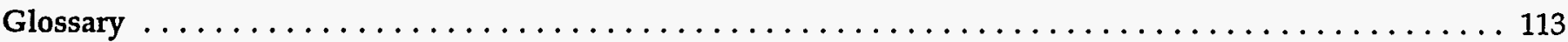

\section{Tables}

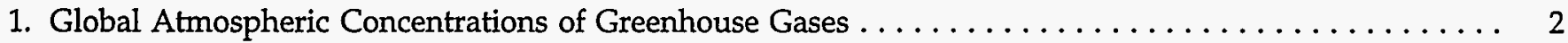

2. Global Natural and Anthropogenic Sources and Absorption of Greenhouse Gases .......... 3

3. Numerical Estimates of Global Warming Potentials Relative to Carbon Dioxide . . . . . . . . . . 6

4. U.S. Carbon Dioxide Emissions from Energy and Industry, $1987-1994 \ldots \ldots \ldots \ldots \ldots \ldots \ldots \ldots$

5. U.S. Carbon Dioxide Emissions from Fossil Energy Consumption by End-Use Sector, 1987-1994 … . 12

6. Comparison of EIA Estimates of Carbon Emissions Coefficients at Full Combustion, 1987-1994 . . . . . 16

7. U.S. Fossil Fuel Consumption for Nonfuel Use, $1987-1994 \ldots \ldots \ldots \ldots \ldots \ldots \ldots \ldots \ldots \ldots \ldots \ldots \ldots$

8. Rates of Sequestration for U.S. Fossil Fuel Consumption $\ldots \ldots \ldots \ldots \ldots \ldots \ldots \ldots \ldots \ldots \ldots \ldots \ldots$

9. U.S. Carbon Sequestered by Nonfuel Use of Energy, $1987-1994 \ldots \ldots \ldots \ldots \ldots \ldots \ldots \ldots \ldots \ldots$. . . . . . . . 19

10. Energy Consumption in U.S. Territories and International Bunkers, $1987-1994 \ldots \ldots \ldots \ldots \ldots$

11. Carbon Emissions from U.S. Territories, International Bunkers, and Unmetered Gas Consumption,

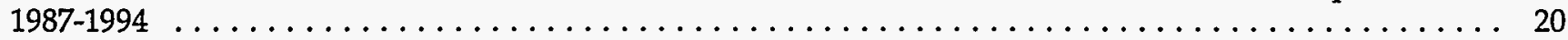

12. U.S. Natural Gas Consumption and Balancing Item, $1987-1994 \ldots \ldots \ldots \ldots \ldots \ldots \ldots \ldots \ldots \ldots \ldots$

13. U.S. Carbon Dioxide Emissions from Gas Flaring, 1987-1994 . . . . . . . . . . . . . . . . . . . . . 22

14. U.S. Carbon Dioxide Emissions from Industrial Sources, $1987-1994 \ldots \ldots \ldots \ldots \ldots \ldots \ldots \ldots \ldots \ldots$

15. U.S. Methane Emissions from Anthropogenic Sources, $1987-1994 \ldots \ldots \ldots \ldots \ldots \ldots \ldots \ldots \ldots . \ldots .25$

16. U.S. Methane Emissions from Coal Mining and Post-Mining Activities, 1987-1994 . . . . . . . . . 26

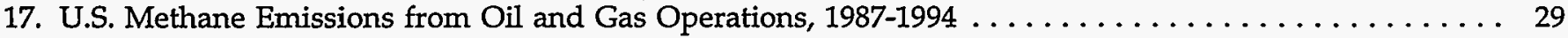

18. U.S. Methane Emissions from Natural Gas Transmission and Distribution, 1987-1994 . . . . . . . . . . 32

19. U.S. Methane Emissions from Oil Refining and Transportation, $1987-1994 \ldots \ldots \ldots \ldots \ldots \ldots \ldots$

20. U.S. Methane Emissions from Stationary Combustion Sources, $1987-1994 \ldots \ldots \ldots \ldots \ldots \ldots \ldots \ldots$. . . . . 34

21. U.S. Methane Emissions from Mobile Sources, $1987-1994 \ldots \ldots \ldots \ldots \ldots \ldots \ldots \ldots \ldots \ldots \ldots \ldots$

22. U.S. Methane Emissions from Anaerobic Decomposition in Landfills, $1987-1994 \ldots \ldots \ldots \ldots$. . . . . . . 36

23. EMCON Methane Generation Model Parameters . . . . . . . . . . . . . . . . . . . 38

24. U.S. Methane Emissions from Enteric Fermentation in Domesticated Animals, 1987-1994 . . . . . . . . 38

25. U.S. Methane Emissions from the Solid Waste of Domesticated Animals, 1987-1994 . . . . . . . . . . . . 40

26. Area of Land Harvested for Rice and Estimated U.S. Methane Emissions from Flooded Rice Fields,

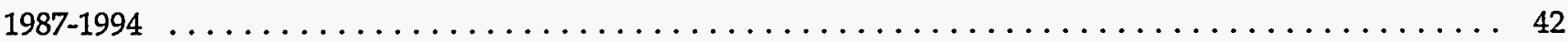

27. U.S. Methane Emissions from Industrial Processes, $1987-1994 \ldots \ldots \ldots \ldots \ldots \ldots \ldots \ldots \ldots \ldots \ldots \ldots$. . . . . . . . . . . . .

28. Estimated U.S. Emissions of Nitrous Oxide, $1987-1994 \ldots \ldots \ldots \ldots \ldots \ldots \ldots \ldots \ldots \ldots \ldots \ldots \ldots$

29. U.S. Nitrous Oxide Emissions from Nitrogen Fertilizer Use, $1987-1994 \ldots \ldots \ldots \ldots \ldots \ldots \ldots \ldots \ldots$. . . . . 47

30. U.S. Nitrous Oxide Emissions from Mobile Sources, $1987-1994 \ldots \ldots \ldots \ldots \ldots \ldots \ldots \ldots \ldots$. . . . . 48

31. U.S. Nitrous Oxide Emissions from Stationary Combustion Sources, 1987-1994 . . . . . . . . . . . . . 49

32. U.S. Nitrous Oxide Emissions from Industrial Processes, $1987-1994 \ldots \ldots \ldots \ldots \ldots \ldots \ldots \ldots \ldots$

33. Estimated 1990 Production, Sales, and Emissions of CFCs and Other Greenhouse Gases . . . . . ... 52

34. Estimated U.S. Emissions of Halocarbons and Miscellaneous Greenhouse Gases, 1987-1994 . . . . . . . 54

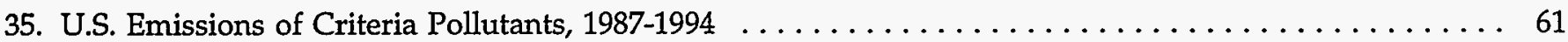

36. U.S. Carbon Monoxide Emissions, $1987-1994 \ldots \ldots \ldots \ldots \ldots \ldots \ldots \ldots \ldots \ldots \ldots \ldots \ldots \ldots \ldots \ldots$

37. U.S. Nitrogen Oxide Emissions, $1987-1994 \ldots \ldots \ldots \ldots \ldots \ldots \ldots \ldots \ldots \ldots \ldots \ldots \ldots \ldots \ldots . \ldots \ldots$

38. U.S. Emissions of Nonmethane Volatile Organic Compounds, $1987-1994 \ldots \ldots \ldots \ldots \ldots \ldots \ldots \ldots$

39. Major Uses of Land in the United States . . . . . . . . . . . . . . . . . . . . 69 


\section{Tables (Continued)}

A1. Carbon Emissions Coefficients at Full Combustion, $1984-1994 \ldots \ldots \ldots \ldots \ldots \ldots \ldots \ldots \ldots \ldots \ldots$

A2. Trends in Motor Gasoline Density, All Grades, $1984-1994 \ldots \ldots \ldots \ldots \ldots \ldots \ldots \ldots \ldots \ldots \ldots \ldots$

A3. Consumption Shares for Liquid Petroleum Gases by Energy Content, 1984-1994 . . . . . . . . . . . . 80

A4. Composition, Energy Content, and Emissions Coefficient for Four Samples of Still Gas . . . . . . . . 80

C1. U.S. Carbon Dioxide Emissions from Energy Use in the Residential Sector, 1983-1994 . . . . . . . . . . 91

C2. U.S. Carbon Dioxide Emissions from Energy Use in the Commercial Sector, 1983-1994 . . . . . . . . . . 91

C3. U.S. Carbon Dioxide Emissions from Energy Use in the Industrial Sector, 1983-1994 . . . . . . . . . . 92

C4. U.S. Carbon Dioxide Emissions from Energy Use in the Transportation Sector, 1983-1994 . . . . . . . . 92

C5. U.S. Carbon Dioxide Emissions from Electric Utilities, $1983-1994 \ldots \ldots \ldots \ldots \ldots \ldots \ldots \ldots \ldots \ldots . \ldots$.

C6. Production Data for Industrial Sources of Carbon Dioxide, $1983-1994 \ldots \ldots \ldots \ldots \ldots \ldots \ldots \ldots \ldots . . . \ldots 3$

C7. U.S. Coal Production, $1983-1994 \ldots \ldots \ldots \ldots \ldots \ldots \ldots \ldots \ldots \ldots \ldots \ldots \ldots \ldots \ldots$

C8. Activity Data for Methane Emissions from Oil and Gas Production, Processing, and Distribution,

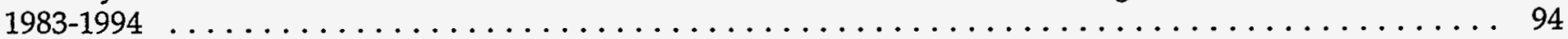

C9. Methane Emissions Factors for Oil and Gas Production, Processing, and Distribution . . . . . . . . . 94

C10. U.S. Municipal Solid Waste Landfilled, $1983-1994 \ldots \ldots \ldots \ldots \ldots \ldots \ldots \ldots \ldots \ldots \ldots \ldots \ldots \ldots . . \ldots 5$

C11. Factors Used To Estimate Methane and Nitrous Oxide Emissions from Burning of Crop Residues . . . . 95

C12. Average Pre-Slaughter Live Weights for U.S. Cattle and Calves, 1984-1994 . . . . . . . . . . . . . . 95

D1. Estimated U.S. Carbon Dioxide Emissions from Biofuels, $1987-1994 \ldots \ldots \ldots \ldots \ldots \ldots \ldots \ldots$. . . . . 97

D2. Estimated Carbon Emissions from U.S. Military Operations Abroad, 1987-1994 . . . . . . . . . . . 98

D3. Estimated U.S. Carbon Dioxide Emissions from Natural Gas Plants, 1987-1994 . . . . . . . . . . . . . 99

\section{Figures}

1. Annual Percentage Change in Atmospheric Concentrations of Carbon Dioxide, Methane,

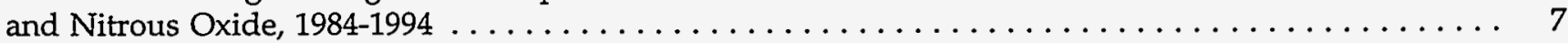

2. Energy-Related Carbon Emissions by Region, $1950-1994 \ldots \ldots \ldots \ldots \ldots \ldots \ldots \ldots \ldots \ldots \ldots \ldots \ldots$

3. Indices of U.S. Gross Domestic Product, Population, Energy Consumption, and Carbon Dioxide Emissions, $1980-1994 \ldots \ldots \ldots \ldots \ldots \ldots \ldots \ldots \ldots \ldots \ldots \ldots \ldots \ldots \ldots$

4. U.S. Energy-Related Carbon Dioxide Emissions by Fuel, $1980-1994 \ldots \ldots \ldots \ldots \ldots \ldots \ldots \ldots \ldots \ldots$. . . . . 14

5. U.S. Energy-Related Carbon Emissions by Sector, $1980-1994 \ldots \ldots \ldots \ldots \ldots \ldots \ldots \ldots \ldots \ldots \ldots \ldots$

6. U.S. Emissions of Nitrous Oxide by Source, $1980-1994 \ldots \ldots \ldots \ldots \ldots \ldots \ldots \ldots \ldots \ldots \ldots$

7. Production, Sales, End Use, and Estimated Emissions of CFC-12, 1980-1994 . . . . . . . . . . . . 55 


\section{Executive Summary}

This is the third annual Energy Information Administration (EIA) report on U.S. emissions of greenhouse gases. This report presents estimates of U.S. anthropogenic (human-caused) emissions of carbon dioxide, methane, nitrous oxide, and several other greenhouse gases for the period 1987 to 1993 . Estimates of 1994 carbon dioxide and halocarbon emissions are also provided, although complete 1994 estimates for other gases are not yet available (Table ES1).

Emissions of carbon dioxide increased by 2 percent in 1993 and by an additional 1.7 percent in 1994. Most carbon dioxide emissions are caused by the burning of fossil fuels for energy consumption, which is strongly related to economic growth, energy prices, and weather. During 1993 and 1994, the U.S. economy grew rapidly.

Estimated emissions of methane declined by 4.8 percent in 1993, largely as a result of a decrease in coal produc- tion from gassy mines due to a strike by the United Mine Workers of America.

Estimated nitrous oxide emissions increased by 3.2 percent in 1993, primarily due to increased use of nitrogen fertilizers and higher output of chemicals linked to nitrous oxide emissions.

Estimated emissions of hydrofluorocarbons (HFCs) and perfluorocarbons (PFCs), which are known to contribute to global warming, increased by 20 percent in 1994, primarily as a result of increasing substitution for chlorofluorocarbons (CFCs).

Only relatively minor revisions have been made in the historical estimates presented in this year's report (see the box on page $x$, "What's New in This Report"). Estimates of carbon dioxide emissions were revised downward by 0.04 to 0.11 percent, with the smallest

Table ES1. Estimated U.S. Emissions of Greenhouse Gases by Gas, 1987-1994 (Million Metric Tons of Gas)

\begin{tabular}{|c|c|c|c|c|c|c|c|c|}
\hline Gas & 1987 & 1988 & 1989 & 1990 & 1991 & 1992 & 1993 & P1994 \\
\hline Carbon Dioxide .......... & $4,820.6$ & $5,046.1$ & $5,080.7$ & $5,035.5$ & $4,988.1$ & $5,062.9$ & $5,156.0$ & $5,243.4$ \\
\hline Methane & 27.0 & 27.6 & 27.6 & 27.9 & 27.9 & 28.0 & 26.6 & NA \\
\hline Nitrous Oxide $\ldots \ldots \ldots \ldots$ & 0.4 & 0.4 & 0.4 & 0.4 & 0.4 & 0.4 & 0.5 & NA \\
\hline \multicolumn{9}{|l|}{ Halocarbons and Minor Gases } \\
\hline CFC- 11, CFC-12, CFC-113 & 0.3 & 0.3 & 0.3 & 0.2 & 0.2 & 0.2 & 0.2 & 0.1 \\
\hline HCFC-22 $\ldots \ldots \ldots \ldots \ldots$ & 0.1 & 0.1 & 0.1 & 0.1 & 0.1 & 0.1 & 0.1 & 0.1 \\
\hline HFCs and PFCs ..... & * & * & * & * & - & * & * & * \\
\hline Methyl Chloroform ....... & 0.3 & 0.3 & 0.3 & 0.3 & 0.2 & 0.2 & 0.2 & 0.1 \\
\hline \multicolumn{9}{|l|}{ Criteria Pollutants } \\
\hline Carbon Monoxide & 95.3 & 96.2 & 91.4 & 94.1 & 90.6 & 87.4 & 88.1 & NA \\
\hline Nitrogen Oxides & 20.3 & 21.1 & 21.1 & 21.0 & 20.8 & 20.8 & 21.2 & NA \\
\hline Nonmethane VOCs . . . . . . . & 22.1 & 22.6 & 21.5 & 22.0 & 21.3 & 20.9 & 21.1 & NA \\
\hline
\end{tabular}

"Less than 50,000 tons of gas. Estimated hydrofluorocarbon and perfluorocarbon emissions combined totaled 0.006 million metric tons in 1987, rising to 0.020 million metric tons in 1994.

$P=$ preliminary data. $N A=$ not available.

Note: Data in this table are revised from the data contained in the previous EIA report, Emissions of Greenhouse Gases in the United States 1987-1992, DOE/EIA-0573 (Washington, DC, November 1994).

Sources: Carbon dioxide, methane, nitrous oxide emissions: EIA estimates described in Chapters 2, 3, and 4 of this report. Halocarbons and minor gases: 1990 estimates from the U.S. Environmental Protection Agency, Office of Air and Radiation, unpublished estimates. Other years: EIA estimates described in Chapter 5 of this report. Criteria pollutants: U.S. Environmental Protection Agency, Office of Air Quality Planning and Standards, National Air Pollutant Emission Trends, 1900-1993, EPA-454/R-94027 (Research Triangle Park, NC, October 1994), Tables A-1-A-3, pp. A-2-A-16. 
revision in 1990 and larger revisions for other years, as a result of revised emissions coefficients and updated 1993 energy data. Methane emissions estimates were revised upward by about 0.8 million metric tons ( 2.9 percent) for each year, primarily as a result of changes in estimation methods.
In Table ES2, the emissions of each gas are weighted by its global warming potential (GWP), which is taken as a measure of radiative forcing. ${ }^{1}$ This concept provides a measure of the comparative impacts of different greenhouse gases on global warming, with the effect of carbon dioxide being equal to 1 . This year, the Inter-

\section{What's New in This Report}

- New global warming potentials. This year's Executive Summary incorporates the new consensus global warming potentials for greenhouse gases published in the latest report by the Intergovernmental Panel on Climate Change, Climate Change 1994. As shown in Table ES2, the new coefficients indicate a somewhat greater effect of methane and nitrous oxide relative to that of carbon dioxide.

- Revised annual emissions coefficients for gasoline, liquefied petroleum gas, jet fuel, and crude oil. The composition of certain petroleum fuels has gradually shifted over time, and the EIA has adopted annual coefficients for several fuels to reflect these shifts. In the United States, changes in gasoline composition have been caused by the phasing out of leaded gasoline, the growing popularity of premium gasoline, and the advent of oxygenated and reformulated gasoline in 1994-1995. The composition of U.S. jet fuel changed in 1994 as the U.S. military began to phase out naphtha-based jet fuels in favor of kerosene-based fuels. The jet fuel coefficient has been revised downward by several percent to reflect more recent information, provided by the Boeing Corporation, on the average density and composition of jet fuel. The net result of these changes has been to reduce estimated carbon emissions by 0.4 to 1.5 million metric tons of carbon ( 0.03 to 0.10 percent) in all years, with the smallest decline in 1990 . The annualized coefficients have caused emissions in the 1980s to be revised downward by greater amounts than emissions in 1990, resulting in a slightly higher historical growth rate for U.S. carbon emissions.

- Revised flare gas estimation methods. EIA's natural gas "venting and flaring" data are used to estimate both carbon dioxide and methane emissions from flare gas. For this year's report, the division between venting and flaring was recalculated on a State-by-State basis, rather than on a national basis. These revisions increased annual methane emissions by about 0.2 million metric tons ( 0.6 percent of total methane emissions).

- Revised historical estimates for methane emissions from coal mines and landfills. The EIA extended the method used to account for methane emissions resulting from coal mine ventilation to provide estimates from the early 1980s. The coal mine estimates were used to generate time series estimates for coal mine methane back to 1980. In addition, methane emissions from municipal solid waste landfilled during the period 1940-1960 have been estimated, slightly increasing the estimates for landfill emissions in the 1990s, with larger increases for estimates in earlier years.

- Expanded coverage of nitrous oxide combustion emissions. Following the method outlined in the final report of the Intergovernmental Panel on Climate Change, the EIA expanded coverage of nitrous oxide emissions from combustion of fossil fuels to cover all combustion, rather than just some sources. This change, however, did not materially affect total nitrous oxide emissions estimates.

- New data on methane and nitrous oxide emissions from agricultural burning. Estimates of this minor emissions source have been added in this year's report, raising estimated methane emissions by 0.1 million metric tons ( 0.3 percent of total methane emissions) and nitrous oxide emissions by 0.005 million metric tons (1 percent of total nitrous oxide emissions).

- Revised 1993 energy data. Last year's report included estimated carbon dioxide emissions based on preliminary 1993 energy data. Final energy consumption data for 1993 were released in early 1995, leading to a small downward revision in estimated 1993 carbon dioxide emissions. This year's report includes preliminary 1994 carbon dioxide emissions estimates, which will be revised next year. 
Table ES2. U.S. Emissions of Greenhouse Gases, Based on Global Warming Potential, 1987-1994 (Million Metric Tons of Carbon or Carbon Equivalent)

\begin{tabular}{|c|c|c|c|c|c|c|c|c|}
\hline Gas & 1987 & 1988 & 1989 & 1990 & 1991 & 1992 & 1993 & P1994 \\
\hline Carbon Dioxide ..... & 1,315 & 1,376 & 1,386 & 1,373 & 1,360 & 1,381 & 1,406 & 1,430 \\
\hline Methane ........ & 181 & 184 & 184 & 187 & 187 & 187 & 178 & NA \\
\hline Nitrous Oxide & 34 & 36 & 38 & 38 & 39 & 39 & 40 & NA \\
\hline HFCs and PFCs & 16 & 20 & 20 & 19 & 20 & 21 & 20 & 24 \\
\hline Total $\ldots \ldots \ldots \ldots \ldots \ldots$ & 1,546 & 1,616 & 1,628 & 1,617 & 1,606 & 1,627 & 1,644 & NA \\
\hline
\end{tabular}

$P=$ preliminary data. $N A=$ not available.

Note: Data in this table are revised from the data contained in the previous EIA report, Emissions of Greenhouse Gases in the United States 1987-1992, DOE/EIA-0573 (Washington, DC, November 1994).

Source: ElA estimates documented in this report.

governmental Panel on Climate Change (IPCC) released new global warming potentials for most greenhouse gases. The GWP of methane was increased from 22 to 24.5 and the GWP of nitrous oxide from 270 to 320 . With the old GWPs, carbon dioxide accounted for about 87 percent of GWP-weighted emissions. With the new GWPs, carbon dioxide accounts for 85 percent of U.S. GWP-weighted emissions.

GWP-weighted emissions rose by 1.7 percent between 1990 and 1993. Declining emissions of methane and halocarbons have not been sufficient to offset rising emissions of carbon dioxide, even with the increased GWPs. Table ES2 excludes CFCs and HCFCs. These gases have ambiguous global warming consequences because of their indirect cooling effects.

In Table ES1, carbon dioxide emissions are shown at full molecular weight. In Table ES2 they are shown in carbon equivalent units (see "Units for Measuring Greenhouse Gases" on page xiii). Trends in the growth of emissions of the major greenhouse gases (Figure ES1) are described below.

\section{Carbon Dioxide}

Some 98.5 percent of U.S. anthropogenic carbon dioxide emissions are caused by the combustion of fossil fuels. The causes of changing carbon dioxide emissions can be found in energy consumption trends and changes in the composition of fossil fuels burned to provide energy services. During the late 1980 s, with rising hydroelectric power generation, the completion of nuclear power plants commissioned in the early 1970s, and increased natural gas use, U.S. anthropogenic emissions of carbon dioxide flattened out, despite rising energy consumption. In 1990 and 1991, with the onset of economic recession and rising oil prices, both energy consumption and carbon emissions declined. The past 3 years, however, have seen economic recovery, falling oil prices, rising energy consumption, and higher levels of carbon dioxide emissions. Emissions rose by 2.0 percent in 1993 and by a further 1.7 percent in 1994, and they are now some 4.1 percent ( 57 million metric tons of carbon) higher than in 1990.

\section{Methane}

U.S. anthropogenic methane emissions have three principal sources: production and transportation of coal, natural gas, and oil; anaerobic decomposition of municipal waste in landfills; and raising livestock. Smaller sources include combustion of fossil fuels, rice cultivation, and industrial processes.

Methane emissions rose during the late 1980s. The principal cause of this trend appears to have been increasing production from a group of underground coal mines with very high rates of methane emissions. Emissions from municipal landfills appear to have been stable, because growth in the volumes of solid waste generated was offset by growing volumes of waste burned for energy recovery and by increased recovery of methane.

In the early 1990s, two factors have tended to reduce estimated methane emissions:

- Underground coal mine production has been declining in the 1990s, and the United Mine Workers strike of 1993 drastically reduced coal production from a number of underground mines known to be very gassy. With the end of the strike, overall coal production rebounded, but production in the gassiest coal mining regions of the United States continued to decline.

- The increasing proliferation of recycling and "waste-to-energy" projects has reduced the apparent volume of trash being put into landfills, and hence, estimated methane emissions from this source. 
Figure ES1. Indices of U.S. Emissions of Greenhouse Gases, 1980-1994

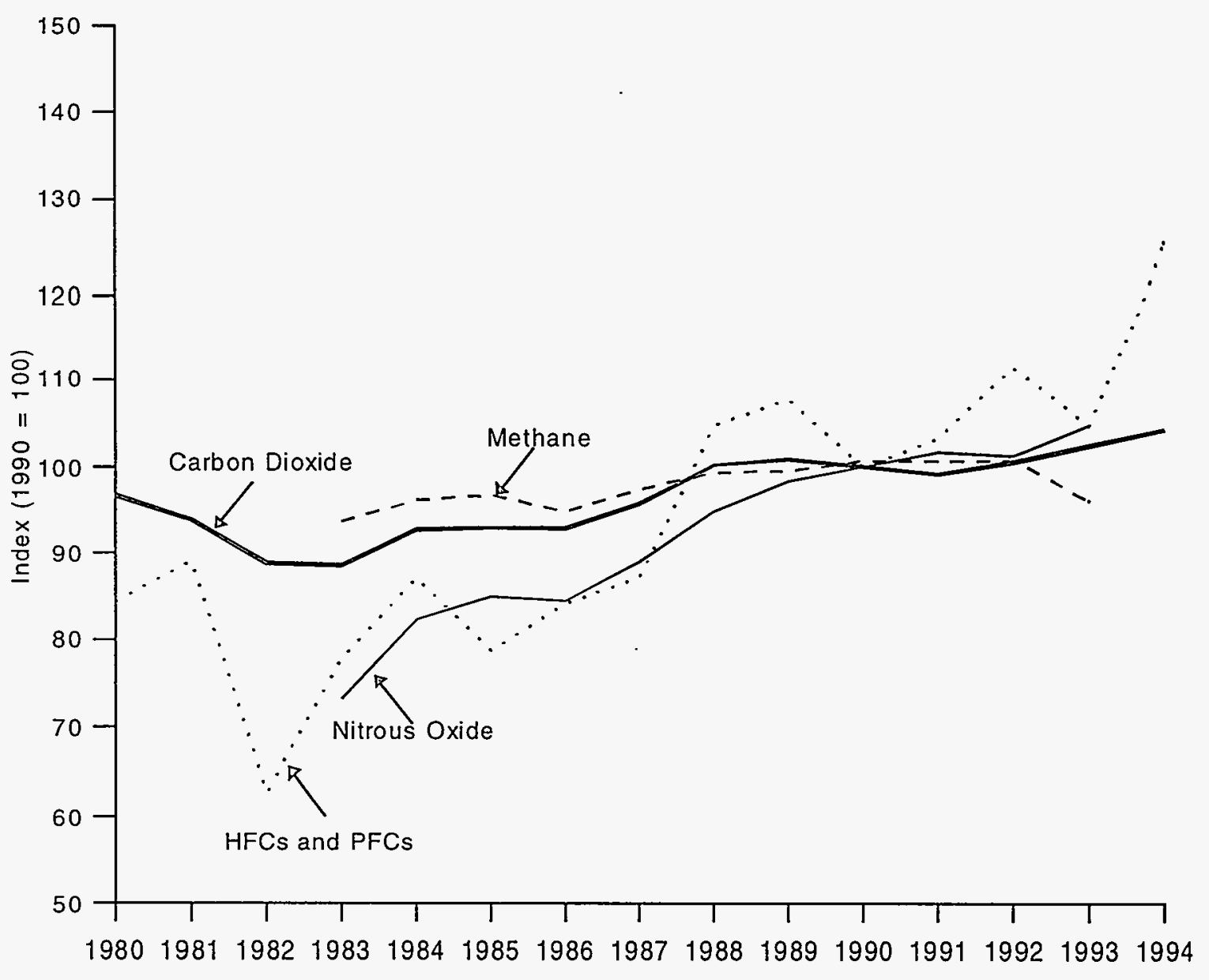

Source: ElA estimates documented in this report.

These factors kept estimated U.S. methane emissions flat from 1990 through 1992 and reduced estimated 1993 emissions by $1: 3$ million metric tons (on a GWPweighted basis, 9 million tons of carbon equivalent).

\section{Nitrous Oxide}

Nitrous oxide emissions are more uncertain than methane emissions: the principal sources are believed to be "excess" emissions from agricultural soils after the application of nitrogen fertilizers, industrial process emissions, and emissions from combustion of fossil fuels. Nitrous oxide emissions, estimated at 0.44 million metric tons in 1990, were roughly stable in 1991 and 1992 but grew by 3.2 percent to 0.46 million metric tons in 1993. The main source of growth was increased use of nitrogen fertilizers and greater industrial process emissions. However, the uncertainty of the estimation methods makes it difficult to be confident of apparent trends.

\section{Halocarbons and Related Compounds}

Halocarbons and related compounds include chlorofluorocarbons (CFCs), hydrochlorofluorocarbons (HCFCs), hydrofluorocarbons (HFCs), perfluorocarbons (PFCs), and some other halogenated compounds that defy simple categorization. All are powerful greenhouse gases with global warming potentials many times that of carbon. 


\section{Units for Measuring Greenhouse Gases}

In this report, the EIA has elected to report information in forms that are most likely to be intuitively familiar to users of the document. Therefore, energy and industrial data are reported in their native units (usually international units). Oil production is reported in thousand barrels per day, and energy production and sales in (higher heating value) quadrillion British thermal units (Btu).

Emissions data are reported in metric units. We have attempted to bridge the gap between users of metric units and international units by using the familiar "million metric tons" common in European industry instead of the "gigagrams" favored by the scientific community.

Emissions of most greenhouse gases are reported here in terms of the full molecular weight of the gas (as in Table ES1). In Table ES2, however, and subsequently throughout the report, carbon dioxide is measured in carbon units, defined as the weight of the carbon content of carbon dioxide (i.e., just the " $\mathrm{C}$ " in $\mathrm{CO}_{2}$ ). Carbon dioxide units at full molecular weight can be converted into carbon units by dividing by $44 / 12$, or 3.67. This approach has been adopted for two reasons:

- Carbon dioxide is most commonly measured in carbon units in the scientific community. Scientists argue that not all carbon from combustion is, in fact, emitted in the form of carbon dioxide. Because combustion is never perfect, some portion of the gases emitted are carbon monoxide, methane, other volatile organic compounds, and particulates. These other gases (particularly carbon monoxide) eventually decay into carbon dioxide, but it is not strictly accurate to talk about "tons of carbon dioxide" emitted.

- Carbon units are more convenient for comparisons with data on fuel consumption and carbon sequestration. Since most fossil fuels are 75 to 90 percent carbon by weight, it is easy and convenient to compare the weight of carbon emissions (in carbon units) with the weight of the fuel burned. Similarly, carbon sequestration in forests and soils is always measured in tons of carbon, so that using carbon units makes it simple to compare sequestration with emissions.

While carbon dioxide emissions can be measured in tons of carbon, emissions of other gases (such as methane) can also be measured in "carbon equivalent" units by multiplying their emissions (in metric tons) by their global warming potential, and then multiplying by 12/44 (as in Table ES2). This method provides a measure of the relative effects of various gases on climate. Because scientific estimates of global warming potential are still evolving, however, this report gives emissions in carbon equivalent units for other gases only in Table ES2. No other data in the report are given in carbon equivalent units.

CFCs are currently being phased out because they damage the stratospheric ozone layer. Ozone, however, is also a greenhouse gas, and gases that destroy tropospheric ozone thus have indirect cooling effects that may offset their direct warming effects as greenhouse gases. Chlorine-containing chemicals (including CFCs and HCFCs) tend to react with ozone; therefore, they have ambiguous effects as greenhouse gases. HFCs and PFCs, which contain no chlorine, have no effect on ozone and thus are unambiguously powerful greenhouse gases.

Figure ES2 illustrates emissions trends for those gases for which sufficient information is available to estimate time series. At present, available data suggest that emissions of CFCs-about 0.2 million metric tons in 1990are declining. Estimated HCFC emissions (almost entirely composed of HCFC-22, a popular refrigerant for home air conditioners) rose in 1994. There is little information about emissions of "new" HCFCs such as HCFC-141b and HCFC-142b, which are CFC substitutes. HFC emissions were very low-perhaps 0.006 million metric tons-in 1990. Emissions of HFC-23, a byproduct of HCFC-22 production, appear to have risen in 1994 with rising HCFC-22 production. Emissions of the CFC substitutes HFC-134a and HFC-152 probably have risen substantially in the past 2 years, from a base of less than 0.001 million metric tons in 1990. HFC-134a became the standard automobile air conditioner refrigerant in 1994, and emissions will grow rapidly as CFCs gradually disappear from the automobile fleet. HFC-152 consumption is growing rapidly, but it has a relatively low global warming potential of 140 . The only quantifiable source of perfluorocarbons is as a fugitive emission from aluminum smelting. Primary aluminum production declined sharply between 1992 and 1994, reducing estimated emissions. 
Figure ES2. Estimated U.S. Emissions of Halocarbons and Related Compounds, 1980-1994

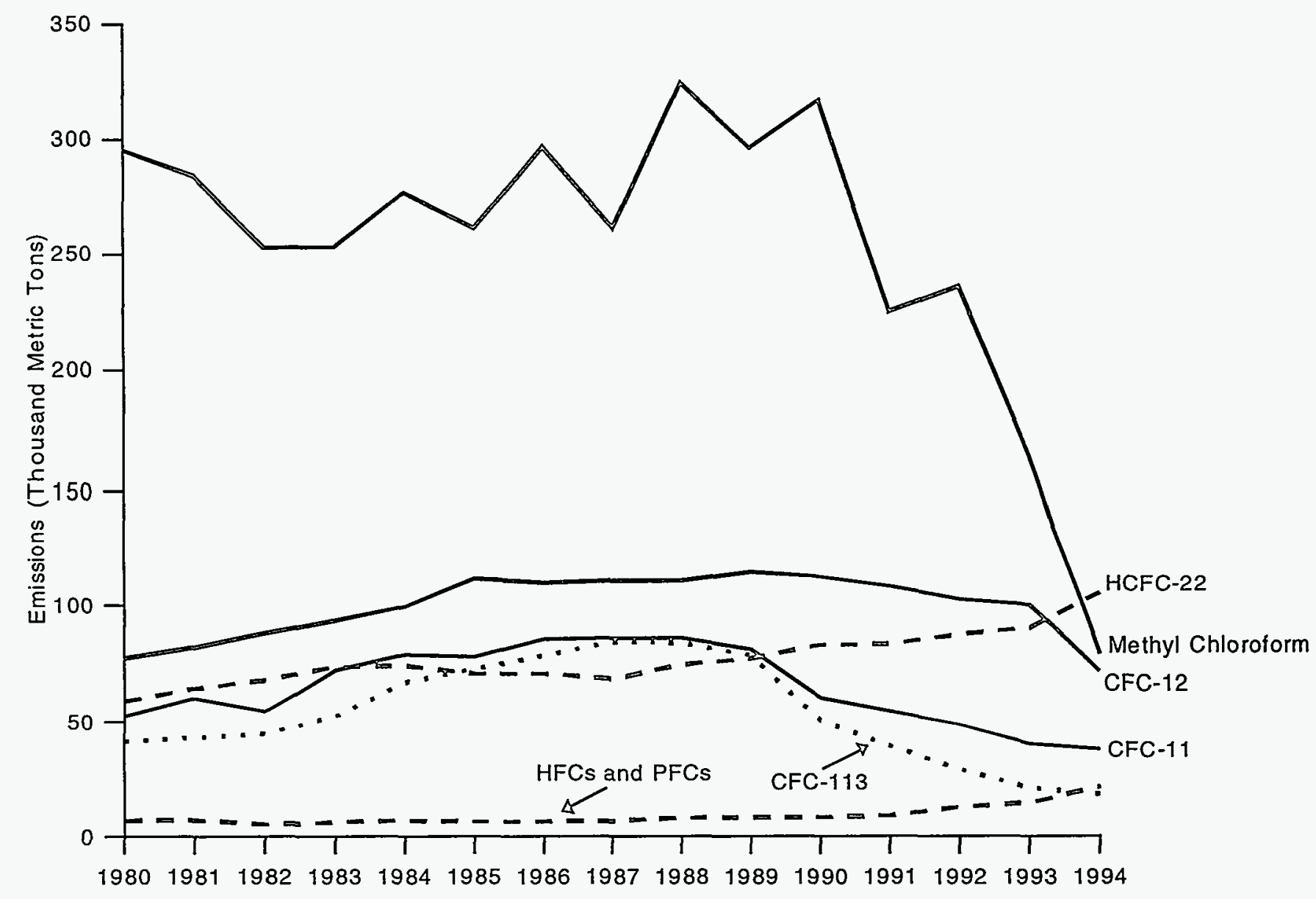

Source: EIA estimates presented in Chapter 5 of this report.

\section{Criteria Pollutants}

Criteria pollutants (carbon monoxide, nitrogen oxides, and nonmethane volatile organic compounds) are shortlived gases, which usually decay quickly in the atmosphere. They are not necessarily greenhouse gases in themselves, but they can promote atmospheric chemical reactions that create tropospheric ozone, which is a potent greenhouse gas. Because the precise ozonecreating effect of these gases varies with local atmospheric conditions, it is not possible to compute their impact directly. As they are precursors to urban "smog," their emissions are regulated under the Clean Air Act. The principal source of emissions of criteria pollutants is the combustion of fossil fuels, particularly in motor vehicles.

According to estimates from the U.S. Environmental Protection Agency (EPA), national-level emissions of carbon monoxide have been declining steadily since the late 1970s (Figure ES3). Emissions of nonmethane volatile organic compounds have also declined, but at a much slower rate. Emissions of nitrogen oxides have been essentially unchanged in recent years. 
Figure ES3. Estimated U.S. Emissions of Criteria Pollutants, 1980-1993

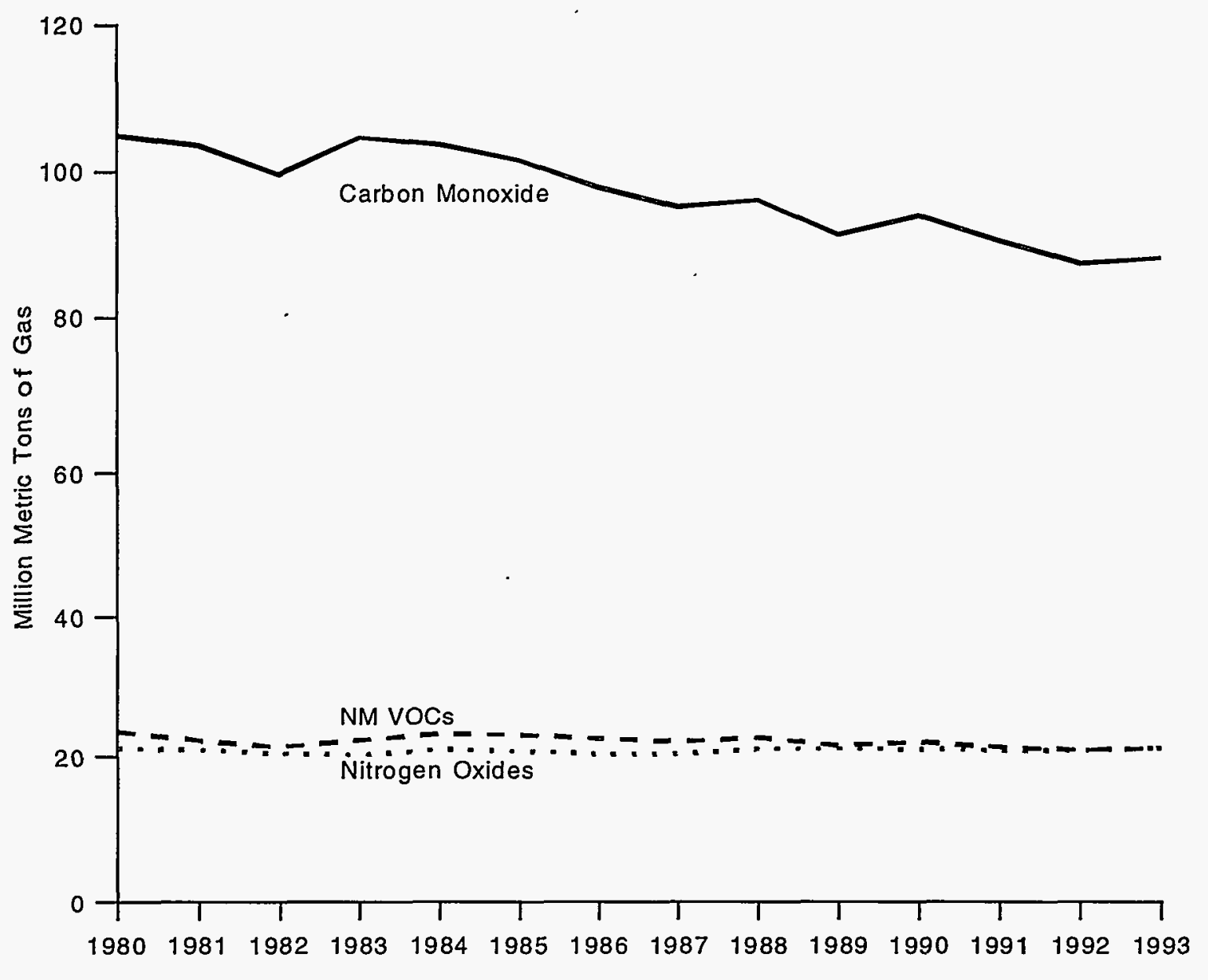

Source: U.S. Environmental Protection Agency, Office of Air Quality Planning and Standards, National Air Pollutant Emission Trends, 1900-1993, EPA-454/R-94-027 (Research Triangle Park, NC, October 1994), Tables A-1-A-3, pp. A-2-A-16.

\section{Land Use Issues}

While the combustion of fossil fuels accounts for most of the anthropogenic emissions of greenhouse gases in the United States, changes in land use can also have large, though difficult to quantify, effects on atmospheric concentrations. In the United States, the expansion of forest land and the growth of existing forests are responsible for removing large amounts of carbon from the atmosphere. Several studies of carbon seques- tration by U.S. forests suggest that in the late 1980s and early 1990s, some 100 to 130 million metric tons of carbon was sequestered annually, equivalent to about 7 to 10 percent of U.S. anthropogenic carbon emissions. ${ }^{2}$ However, considerable uncertainty is associated with this estimate-particularly, the amount of carbon sequestered in forest soils.

The IPCC recommends including emissions and sequestration from land use changes in national inventories,

${ }^{2}$ R. Birdsey, U.S. Department of Agriculture, Carbon Storage and Accumulation in United States Forest Ecosystems (Washington, DC, August 1992), p. 3; U.S. Environmental Protection Agency, The Forest Sector Carbon Budget of the United States: Carbon Pools and Flux Under Alternative Policy Options, EPA/600/3-93/093 (Washington, DC, May 1993), p. xiii; and U.S. Department of Energy, The Climate Change Action Plan: Technical Supplement, DOE/PO-0011 (Washington, DC, March 1994), p. 30. 
and the U.S. "National Communication" for the Framework Convention follows this practice. ${ }^{3}$ However, the EIA has elected not to include land use changes in its "total" estimate of U.S. emissions, due to difficulties in definition, completeness of coverage, and developing credible sequestration time series. This report does describe the elements of a comprehensive estimate of emissions and sequestration from land use changes, discusses estimates made by others for most of the elements studied, and describes some of the conceptual and data problems involved in preparing estimates. 


\section{U.S. Emissions of Greenhouse Gases in Perspective}

\section{About this Report}

The Energy Information Administration (EIA) is required by the Energy Policy Act of 1992 to prepare a report on aggregate U.S. national emissions of greenhouse gases for the period 1987-1992, with annual updates thereafter. This is the third annual update report, covering national emissions over the period 1987-1993, with preliminary estimates of U.S. carbon dioxide and halocarbon emissions for 1994.

Calculating national aggregate emissions (or "national inventories") of greenhouse gases is a recently developed form of intellectual endeavor. Greenhouse gas emissions are rarely measured directly or reported to statistical agencies. Thus, to prepare emissions inventories usually requires inferring emissions indirectly from information collected for other purposes. Both the available information and the inferences drawn may be of varying reliability.

Chapter 1 of this report briefly recapitulates some background information about global climate change and the greenhouse effect and discusses important recent developments in global climate change activities. Chapters 2 through 6 cover emissions of carbon dioxide, methane, nitrous oxide, halocarbons, and criteria pollutants, respectively. Chapter 7 describes potential sequestration and emissions of greenhouse gases as a result of land use changes.

Five appendices are included with this report. Appendix $\mathrm{A}$ describes the derivation of the carbon emissions coefficients used for the inventory. Appendix B describes uncertainties in emissions estimates. Appendix $C$ contains tables extending some of the principal emissions estimates back to 1983, as well as some of the background data used to derive emissions estimates. Appendix $D$ describes known emissions sources omitted from the main report due to definitions of "anthropogenic" or due to excessive uncertainty. Appendix E provides some convenient conversion factors.

\section{Emissions Inventories}

Greenhouse gas emissions inventories were first prepared in the late 1970 s by or for atmospheric scientists, who sought to determine and analyze the human contribution to rising atmospheric concentrations of greenhouse gases. Emissions were assigned to particular countries primarily as a matter of convenience, because underlying energy and industrial production data were organized at the national level. The accuracy of early estimates did not need to be particularly high, nor was there any requirement for detail. However, as climate change has shifted from being a matter of scientific debate to a topic of policy concern, both the methods of computing inventories and the level of detail that is desirable have changed.

The United Nations' Intergovernmental Panel on Climate Change (IPCC) has been asked to develop a methodology for national inventories that will provide comparable estimates across nations. The IPCC developed an initial draft methodology for preparing national inventories in 1991: a final document was published this year. ${ }^{1}$ The IPCC document itself is aimed at a range of countries with widely differing national statistical systems and widely varying capacities: consequently, the IPCC methods are designed to be applicable to countries with varying levels of sophistication. This report follows the IPCC guidelines to the extent that they are consistent with available U.S. data and national emissions sources.

All emissions inventories have inherent limitations in their accuracy and comparability. The first problem is the absence of any directly measured or reported information on greenhouse gas emissions, and the consequent necessity to infer emissions from available information. In the case of carbon dioxide, emissions are calculated by multiplying reported energy consumption by the estimated carbon content of fossil fuels. This is a fairly reliable estimate; both energy statistics and estimates of carbon content are probably

\footnotetext{
'Intergovernmental Panel on Climate Change, IPCC Guidelines for National Greenhouse Gas Inventories, Vols. 1-3 (Paris, France, 1995).
} 
accurate within a few percent. For methane and nitrous oxide, however, emissions are generally inferred by extrapolating experiments conducted on small number of samples across a large, national, sometimes heterogenous population. As a result, methane and nitrous oxide emissions estimates are much more uncertain than carbon dioxide emissions estimates, and they are more prone to large revisions as additional information becomes available. The reliability of emissions estimates for halocarbons and other gases varies considerably, depending in part on the degree of commercial and regulatory importance of each gas.

A second source of difficulty in preparing national emissions estimates lies in definitional questions. The international community has devoted considerable resources to developing common definitions and rules for the computation of economic statistics (particularly, trade and national accounts statistics), but the definition of common rules for emissions inventories has only just begun. In this report, emissions estimates that are affected by definitional questions include the following:

- Emissions associated with bunker fuels and U.S. territories are included in the U.S. totals, but emissions associated with U.S. military operations abroad are excluded.

- Carbon emissions associated with biomass combustion, including intentional burning of wood and alcohol as well as forest fires and crop burning, are excluded.

- Emissions and sequestration associated with land use changes are dealt with separately, both because of definitional problems and because of the sparsity and uncertainty of available information.

\section{Global Climate Change and the Greenhouse Effect}

The composition of the Earth's atmosphere is a primary determinant of the planet's temperature, which in turn establishes the conditions and limits for all life on
Earth. Without the heat-trapping properties of so-called "greenhouse gases," which make up no more than 1 or 2 percent of the Earth's atmosphere, the average surface temperature of the Earth would be similar to that of Mars: -60 degrees Fahrenheit (-16 degrees Celsius).

The main greenhouse gases are water vapor $\left(\mathrm{H}_{2} \mathrm{O}\right)$, carbon dioxide $\left(\mathrm{CO}_{2}\right)$, methane $\left(\mathrm{CH}_{4}\right)$, nitrous oxide $\left(\mathrm{N}_{2} \mathrm{O}\right)$, and halocarbons (such as CFC-11 and CFC-12). With the exception of halocarbons, most greenhouse gases occur naturally. Water vapor is by far the most common, with an atmospheric concentration of nearly 1 percent, compared with less than 0.04 percent for carbon dioxide. Concentrations of other greenhouse gases are a fraction of that for carbon dioxide (Table 1).

In computer-based simulation models, rising concentrations of greenhouse gases nearly always produce an increase in the average temperature of the Earth. Rising temperatures may, in turn, produce changes in weather and in the level of the oceans that might prove disruptive to current patterns of land use and human settlement, as well as to existing ecosystems. To date, it has proven difficult to detect hard evidence of actual temperature changes, in part, because normal temporal and spatial variations in temperature are far larger than the predicted change in the global average temperature. Even when temperature changes are identified, it is not possible to be certain whether they are random fluctuations that will reverse themselves or the beginning of a trend. The possible effects of rising temperatures on weather patterns are even more uncertain.

\section{Global Sources of Greenhouse Gases}

Most greenhouse gases have substantial natural sources in addition to human-made sources, and there are powerful natural mechanisms for removing them from the atmosphere. However, the continuing growth in atmospheric concentrations establishes that for each of the major greenhouse gases, more gas is being emitted than is being absorbed each year: that is, the natural absorption mechanisms are lagging behind. Table 2 illustrates the relationship between anthropogenic and

Table 1. Global Atmospheric Concentrations of Greenhouse Gases

\begin{tabular}{|c|c|c|c|c|c|}
\hline \multirow[b]{2}{*}{ Item } & Carbon Dioxide & Methane & Nitrous Oxide & CFC-11 & CFC-12 \\
\hline & \multicolumn{3}{|c|}{ (parts per million) } & \multicolumn{2}{|c|}{ (parts per trillion) } \\
\hline Preindustrial Atmospheric Concentration. . & 278 & 0.700 & 0.275 & 0 & 0 \\
\hline 1990 Atmospheric Concentration & 356 & 1.714 & 0.311 & 268 & 503 \\
\hline Average Change (PPM or PPT per year). & 1.0 & 0.007 & 0.0007 & 2 & 13 \\
\hline
\end{tabular}

Source: M. Prather et al., "Other Trace Gases and Atmospheric Chemistry," in Intergovernmental Panel on Climate Change, Climate Change 1994: Radiative Forcing of Climate Change (Cambridge, UK: Cambridge University Press, 1995), p. 80. 
Table 2. Global Natural and Anthropogenic Sources and Absorption of Greenhouse Gases

\begin{tabular}{c|r|r|r|c}
\hline \multirow{2}{*}{ Gas } & \multicolumn{2}{|c|}{ Sources } & & Annual Increase in Gas \\
\cline { 2 - 3 } in the Atmosphere
\end{tabular}

Source: Summarized from ranges appearing in Intergovernmental Panel on Climate Change, Climate Change 1994: Radiative Forcing of Climate Change (Cambridge, UK: Cambridge University Press, 1995), pp. 41, 51, 86, and 90.

natural emissions and absorption of the principal greenhouse gases.

Carbon Dioxide. Carbon is an extremely common element on the planet, and immense quantities can be found in the atmosphere, in soils, in carbonate rocks, and dissolved in ocean water. All life on earth participates in the "carbon cycle," by which carbon dioxide $\left(\mathrm{CO}_{2}\right)$ is extracted from the air by plants and decomposed into carbon and oxygen, the carbon is incorporated into plant biomass, and the oxygen is released to the atmosphere. Plant biomass, in turn, ultimately decays (oxidizes), releasing carbon dioxide back into the atmosphere, or storing organic carbon in soil or rock. There are vast exchanges of carbon dioxide between the ocean and the atmosphere, with the ocean absorbing carbon from the atmosphere and plant life in the ocean absorbing carbon from water, dying, and raining organic carbon on the sea bottom, where it is eventually incorporated into carbonate rocks such as limestone. Records from Antarctic ice cores indicate that the carbon cycle has been in a state of imbalance for the past 200 years, with emissions of carbon dioxide to the atmosphere exceeding absorption. Consequently, carbon dioxide concentrations in the atmosphere have been steadily rising.

The most important natural sources of carbon dioxide are releases from the oceans ( 100 billion metric tons per year), aerobic decay of vegetation (30 billion metric tons), and plant and animal respiration ( 30 billion metric tons). Known anthropogenic sources account for 7 billion metric tons of carbon per year. The principal anthropogenic source is the combustion of fossil fuels, which accounts for about three-quarters of total anthropogenic emissions of carbon worldwide. Natural processes, known and unknown, absorb substantially all of the naturally produced carbon dioxide and some of the anthropogenic carbon dioxide, leading to an annual net increase in carbon dioxide in the atmosphere of 3.2 to 3.6 billion metric tons.
Methane. Methane $\left(\mathrm{CH}_{4}\right)$ is also a common compound. The methane cycle is understood less well than is the carbon cycle. Methane is released primarily by anaerobic decay of vegetation, by the digestive tracts of termites in the tropics, and by several other lesser sources. The principal anthropogenic sources are leakages from the production of fossil fuels, humanpromoted anaerobic decay in landfills, and the digestive tracts of domestic animals. The main sources of absorption are thought to be decomposition (into carbon dioxide) in the atmosphere and decomposition by bacteria in soil. Known sources and sinks of methane are estimated to total about 500 million metric tons each. The annual increase in methane concentrations in the atmosphere is estimated at 35 to 40 million metric tons.

Nitrous Oxide. The sources and absorption of nitrous oxide $\left(\mathrm{N}_{2} \mathrm{O}\right)$ are much more speculative than those for other greenhouse gases. The principal sources are thought to be bacterial breakdown of nitrogen in soils, particularly forest soils, and fluxes from ocean upwellings. The primary human-made sources are enhancement of natural processes through application of nitrogen fertilizers, combustion of fuels, and certain industrial processes. The most important sink is thought to be decomposition in the stratosphere. Worldwide estimated known sources of nitrous oxide total 13 to 20 million metric tons, and known sinks total 10 to 17 million metric tons. The annual increase in concentrations in the atmosphere is thought to total about 4 million metric tons.

Halocarbons and Other Miscellaneous Chemicals. In the twentieth century, human ingenuity has produced an array of "engineered" chemicals not normally found in nature, whose special characteristics render them particularly useful. Some engineered chemicals are also greenhouse gases. The best known class of greenhouse chemicals are the chlorofluorocarbons (CFCs), particularly CFC-12, often known by its trade name, "freon." CFCs have many desirable features: they are relatively 
simple to manufacture, inert, nontoxic, and nonflammable. Because CFCs are chemically stable, once emitted, they remain in the atmosphere for hundreds or thousands of years. Because they are not found in nature, these molecules occupy an infrared "window" that would otherwise be largely unoccupied, and they are potent greenhouse gases, with a direct radiative forcing effect hundreds or thousands of times that of carbon dioxide.

CFCs can be destroyed by sunlight. This reaction, however, releases free chlorine into the stratosphere, and the free chlorine tends to destroy stratospheric ozone, which protects the surface of the earth from solar ultraviolet radiation at wavelengths that are potentially damaging to plant and animal life (ultraviolet radiation, for example, is one cause of human and animal skin cancers). The destruction of stratospheric ozone, notwithstanding its potential damage to living organisms, exerts a net cooling effect on the surface of the planet, making the net effects of CFCs on radiative forcing ambiguous. Recent research suggests that the negative indirect effects of CFCs during the 1980s may have been relatively small, and that the positive direct effect may have predominated. ${ }^{2}$

The threat posed by CFCs to the ozone layer has caused the United States and many other countries to commit themselves to phasing out the production of CFCs pursuant to an international treaty, the 1987 Montreal Protocol. As emissions of CFCs have declined, many related chemicals have emerged as alternatives, including hydrochlorofluorocarbons (HCFCs) and hydrofluorocarbons (HFCs). HCFCs are similar to CFCs, but they are more reactive and consequently have shorter atmospheric lives, with less effect on the ozone layer and smaller direct global warming effects. HFCs have no chlorine, and consequently have no effect on the ozone layer, but they have potentially powerful direct effects on climate. HFCs were rare before 1990, but in 1994 HFC-134a was adopted as the standard motor vehicle air conditioning refrigerant in virtually all new cars made in America. Consequently, HFC emissions are now rising rapidly, though from a negligible base.

Beyond the halocarbons (CFCs, HFCs, HCFCs, and HFCs) there are a range of engineered chemicals, produced in relatively small quantities, which also have direct radiative forcing effects. These include the perfluorocarbons $\left(\mathrm{CF}_{4}\right.$ and $\left.\mathrm{C}_{2} \mathrm{~F}_{6}\right)$ emitted as byproducts of aluminum smelting, some industrial solvents such as carbon tetrachloride, methyl chloroform, methylene chloride, and other more obscure chemicals such as sulfur hexafluoride $\left(\mathrm{SF}_{6}\right)$ and, possibly, other chemicals not yet identified. Some of these compounds are regulated in the United States as ozone depleters, or for toxicity, or both. Recent research suggests that some of the ozone-depleting solvents with low global warming potentials (such as methyl chloroform) may have had a net cooling effect on the global climate during the $1980 s^{3}$

Criteria Pollutants. Finally, there are three gases, emitted primarily as a side effect of combustion (both of fossil fuels and of biomass), which have an indirect effect on global warming: carbon monoxide, nitrogen oxides, and nonmethane volatile organic compounds (NMVOCs). These compounds are regulated in the United Sates pursuant to the Clean Air Act, and are often referred to (along with particulates, lead, and sulfur dioxide) as "criteria pollutants." The criteria pollutants are highly reactive compounds, and they tend to remain in the atmosphere for only hours or days. The sequence of reactions that removes them from the atmosphere, however, tends to promote the formation of ozone $\left(\mathrm{O}_{3}\right)$, a reactive and unstable molecular form of oxygen. While ozone in the stratosphere protects life on Earth from ultraviolet radiation, ozone at ground level at high concentrations causes respiratory distress in people and animals and also is, itself, a potent (though short-lived) greenhouse gas.

It has not proven possible to make a general determination of the contribution of criteria pollutants to global warming. The reactions that produce ozone are strongly affected by the relative concentrations of various pollutants, the ambient temperature, and local weather. Emissions of criteria pollutants can create very high, though localized, ozone concentrations under favorable conditions (for example, a warm, sunny day combined with still air and low humidity) and negligible concentrations under unfavorable conditions. The criteria pollutants are included in this report for completeness.

\section{Relative Forcing Effects of Various Gases}

Some greenhouse gases are more potent at affecting global temperatures than are others. As a result, comparable increases in the concentrations of different greenhouse gases can have vastly different heattrapping effects. Among those identified, carbon dioxide is least effective as a greenhouse gas. Considering only heat-absorption potential, one molecule of

\footnotetext{
2Intergovernmental Panel on Climate Change, Climate Change 1994: Radiative Forcing of Climate Change (Cambridge, UK: Cambridge University Press, 1995), pp. 173-177.

${ }^{3}$ Intergovernmental Panel on Climate Change, Climate Change 1994: Radiative Forcing of Climate Change (Cambridge, UK: Cambridge University Press, 1995), p. 177.
} 
methane can have 24 times the effect on climate that one molecule of carbon dioxide has. ${ }^{4}$

It would be useful to determine the precise relative effectiveness of various greenhouse gases in affecting the Earth's climate. This information would help policymakers know whether it would be more effective to concentrate effort on reducing the very small emissions of powerful greenhouse gases, such as carbon tetrafluoride, or whether they should bend their efforts to controlling the very large emissions of relatively ineffective gases, such as carbon dioxide.

There has been extensive study of the relative effectiveness of various greenhouse gases in trapping the Earth's heat. This research has led to the development of the concept of a "global warming potential," or GWP. The GWP is intended to demonstrate the relative impacts on global warming of various gases, compared with carbon dioxide. Over the past few years, the IPCC has conducted an extensive research program aimed at summarizing the effects of various greenhouse gases through a set of GWPs. The results of that work were released this year in a new IPCC report, Climate Change 1994.5

The IPCC's work has established that the effects of various gases on global warming are too complex to permit them to be easily summarized as a single number. The complexity takes three forms:

- Each gas absorbs radiation in a particular set of wavelengths or "window," in the spectrum. In some cases, where concentrations of the gas are low and no other gases block radiation in the same window, small emissions of the gas will have a disproportionate absorptive effect. However, if concentrations of the gas rise over time, a larger and larger portion of the total light passing through the "window" will already have been captured, and the effects of additional emissions will decline. Therefore, the effect of an additional unit of emissions of a gas that is relatively plentiful in the atmosphere, such as carbon dioxide, tends to be less than that of a rare gas, such as sulfur hexafluoride.

- Various natural processes cause many greenhouse gases to decompose into other gases, or to be absorbed into the ocean or ground. These processes can be summarized in terms of the "atmospheric lifetime" of a particular gas, or the period of time it would take for natural processes to remove a unit of emissions from the atmosphere. Some gases, such as CFCs, have very long atmospheric lifetimes, in the hundreds of years, while others, such as carbon monoxide, have lives measured in hours or days. Methane, which decays into carbon dioxide over a period of a few years, has a much larger short-run effect on global warming than does an equivalent amount of carbon dioxide. However, over longer and longer periods-from 10 years to 100 years to 500 years, for example-the differences between the GWPs of methane and carbon dioxide become less significant.

- Many gases are chemically active, and they may react in the atmosphere in ways that promote or hinder the formation of other greenhouse gases. For example, nitrogen oxides and carbon monoxide combine to promote the formation of ozone, which is a potent greenhouse gas, while CFCs tend to destroy atmospheric ozone, thus promoting global cooling. These indirect effects have proven impossible to summarize in terms of global warming potentials. In some cases, such as CFCs, it is unclear whether they contribute to a net warming or cooling of the Earth's atmosphere. In other cases, it is clear that they contribute to a net warming, but the magnitude of the indirect effect is unclear.

Despite such complexity, the needs of policymakers have kept the scientific community at work. Table 3 summarizes the consensus results of the most recent studies by scientists working on behalf of the IPCC, showing estimates of atmospheric lifetimes and global warming potentials across various time scales. The new global warming potentials are generally comparable to those published in the IPCC's previous report, Climate Change $1992 .{ }^{6}$ However, there have been two changes, which, while not large, can affect the estimates presented in this report: (1) the point estimate of the GWP (for 100-year integration) of methane has been raised from 22 to 24.5, and (2) the GWP of nitrous oxide has been raised from 270 to 320 . The GWPs of several minor gases-notably, HFC-23, perfluoromethane $\left(\mathrm{CF}_{4}\right)$, and perfluoroethane $\left(\mathrm{C}_{2} \mathrm{~F}_{6}\right)$-included in this report have also been raised. Consequently, the apparent contribution (and hence, relative importance) of methane, nitrous oxide, and other gases to climate change has increased slightly compared with carbon dioxide.

${ }^{4}$ D. Wuebbles and J.A. Edmonds, Primer on Greenhouse Gases (Chelsea, MI: Lewis Publisher, Inc., 1991 ), p. 15.

Intergovernmental Panel on Climate Change, Climate Change 1994: Radiative Forcing of Climate Change (Cambridge, UK: Cambridge University Press, 1995).

'T.S.K. Isakson et al., "Radiative Forcing of Climate," in Intergovernmental Panel on Climate Change, Climate Change 1992: The Supplementary Report to the IPCC Assessment (Cambridge, UK: Cambridge University Press, 1992), p. 56. 
Table 3. Numerical Estimates of Global Warming Potentials Relative to Carbon Dioxide (Carbon Dioxide $=1$ )

\begin{tabular}{|c|c|c|c|c|}
\hline \multirow[b]{2}{*}{ Gas } & \multirow{2}{*}{$\begin{array}{l}\text { Lifetime } \\
\text { (Years) }\end{array}$} & \multicolumn{3}{|c|}{ Direct Effect for Time Horizons of } \\
\hline & & 20 Years & 100 Years & 500 Years \\
\hline Carbon Dioxide & 120 & 1 & 1 & 1 \\
\hline Methane $\ldots \ldots \ldots \ldots$ & 14.5 & 62 & 24.5 & 7.5 \\
\hline Nitrous Oxide $\ldots \ldots \ldots \ldots$ & 120 & 290 & 320 & 180 \\
\hline \multicolumn{5}{|l|}{ Halocarbons } \\
\hline CFC-11 & 50 & 5,000 & 4,000 & 1,400 \\
\hline CFC-12 & 102 & 7,900 & 8,500 & 4,200 \\
\hline CFC-113 & 85 & 5,000 & 5,000 & 2,300 \\
\hline CFC-114 $\ldots \ldots \ldots \ldots$ & 300 & 6,900 & 9,300 & 8,300 \\
\hline CFC-115 $\ldots \ldots \ldots \ldots$ & 1,700 & 6,200 & 9,300 & 13,700 \\
\hline Halon $1301 \ldots \ldots \ldots \ldots$ & 65 & 6,500 & 5,600 & 2,200 \\
\hline HCFC-22 $\ldots \ldots \ldots \ldots$ & 13.3 & 4,300 & 1,700 & 520 \\
\hline HCFC-123 $\ldots \ldots \ldots \ldots$ & 1.4 & 300 & 93 & 29 \\
\hline HCFC-124 & 5.9 & 1,500 & 480 & 150 \\
\hline HCFC-141b & 9.4 & 1,800 & 630 & 200 \\
\hline HCFC-142b & 19.5 & 4,200 & 2,000 & 630 \\
\hline HFC-23 & 250 & 9,200 & 12,100 & 9,900 \\
\hline HFC-125 & 36 & 4,800 & 3,200 & 11 \\
\hline HFC-134a & 14 & 3,300 & 1,300 & 420 \\
\hline HFC-152a & 1.5 & 460 & 140 & 44 \\
\hline$\ldots \ldots \ldots \ldots$ & 41 & 4,500 & 3,300 & 1,100 \\
\hline Perfluoromethane $\ldots \ldots \ldots$ & 50,000 & 4,100 & 6,300 & 9,800 \\
\hline Perfluoroethane & 10,000 & 8,200 & 12,500 & 19,100 \\
\hline \multicolumn{5}{|l|}{ Other Chemicals } \\
\hline Carbon Tetrachloride & 42 & 2,000 & 1,400 & 500 \\
\hline Methyl Chloroform .. & 5.4 & 360 & 110 & 35 \\
\hline Methylene Chloride . . . . . . & 0.41 & 28 & 9 & 3 \\
\hline Chloroform . . . . . . . . & 0.55 & 15 & 5 & 1 \\
\hline Sulfur Hexafluoride & 3,200 & 16,500 & 24,900 & 36,500 \\
\hline
\end{tabular}

Source: D.L. Albritton et al., "Trace Gas Radiative Forcing Indices," in J.T. Houghton et al., Climate Change 1994 (Cambridge, UK: Cambridge University Press, 1995), p. 222.

\section{Recent Developments}

\section{Changing Growth in Atmospheric Concentrations}

It is exceptionally difficult to determine unambiguously whether or not global warming is actually taking place, and it is even more difficult to determine the consequences of global warming for the Earth's climate. Finally, it is yet more difficult to determine how changes in climate may affect natural ecosystems and the human economy. The incontrovertible empirical observation is that global atmospheric concentrations of greenhouse gases are rising steadily, and have been for decades. Carbon dioxide concentrations in the atmosphere have been directly recorded, using consistent methods, since 1958, and concentrations of methane and nitrous oxide have been recorded for the past 15 years. Since the initial discovery that carbon dioxide concentrations in the atmosphere were increasing, scientists have exercised enormous ingenuity in pushing the record of atmospheric concentrations backward, using samples of "fossil air" trapped in ice cores from Greenland and the antarctic.

The long-run records indicate that both carbon dioxide and methane concentrations in the Earth's atmosphere stand at levels not previously attained (at least for any prolonged period) over the past 160,000 years. The growth in concentrations has occurred largely in the past 200 years, and especially since 1940 .

Both the timing of the growth in concentrations, anomalous variations in observations between the 
northern and southern hemispheres, and observations of relative concentrations of isotopes in atmospheric carbon dioxide (fossil carbon has a different distribution of isotopes than carbon of contemporary biologic origin) all imply that the prime source for the growth in carbon dioxide concentrations is the combustion of fossil fuels in the northern hemisphere.

Thus, it was particularly striking when, as noted in last year's report, there was a sudden slowing in the growth rate of atmospheric concentrations of both carbon dioxide and methane over the period 1990-1993 (Figure 1). This slowing first began to appear in 1990 and has continued through 1993. In the early 1980s, carbon dioxide concentrations were growing by 0.4 percent per year (Figure 1). During the period 1990-1993, the growth of atmospheric concentrations slowed to less than 0.2 percent annually. While the level of energyrelated carbon dioxide emissions dropped slightly (due to sharply reduced energy consumption in the former

Figure 1. Annual Percentage Change in Atmospheric Concentrations of Carbon Dioxide, Methane, and Nitrous Oxide, 1984-1994

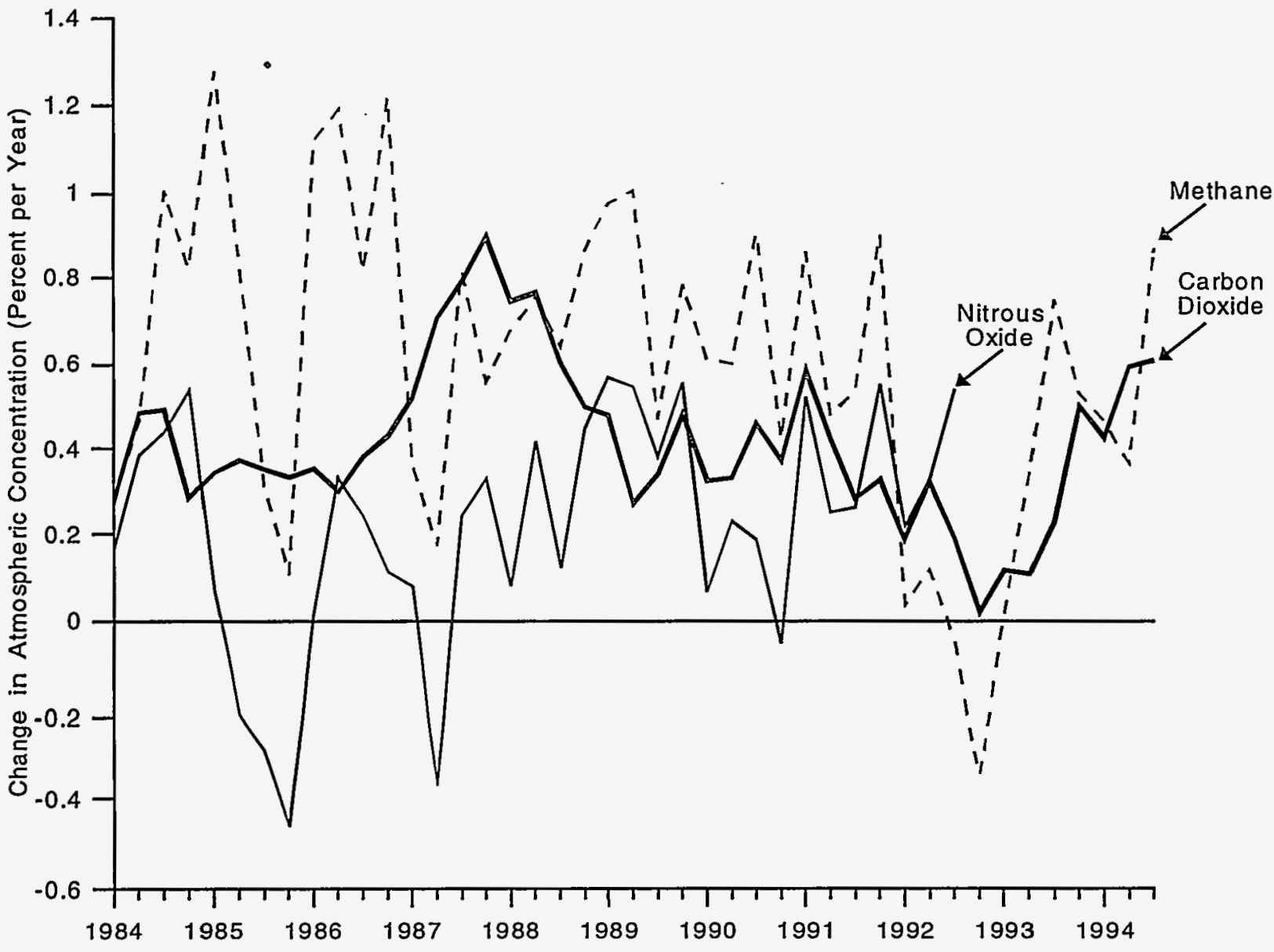

Source: C.D. Keeling and T.P. Whorf (1993), "Atmospheric $\mathrm{CO}_{2}$ Records from Sites in the SIO Air Sampling Network," pp. 18-28, and E.J. Dlugokencky, P.M. Lang, K.A. Massarie, and L.P. Steel (1994), "Atmospheric $\mathrm{CH}_{4}$ Records from Sites in the NOAACMDL Air Sampling Network," pp. 50-126, in T.A. Boden, D.P. Kaiser, R.J. Stepanski, and F.W. Stoss (eds.), Trends '93: A Compendium of Data on Global Change, ORNLCDIAC-65 (Oak Ridge, TN: Carbon Dioxide Information Analysis Center, Oak Ridge National Laboratory, in press, 1994).

${ }^{7}$ Energy Information Administration, Emissions of Greenhouse Gases 1987-1992, DOE/EIA-0573 (Washington, DC, November 1994 ), p. 3. 
Soviet Union and Eastern Europe), the decline is far too small to account for the observed sharp drop in the growth of atmospheric concentrations. Consequently, either natural sources of emissions have also declined, or natural absorption has increased.

In 1994, the growth in carbon dioxide concentrations resumed its previous trend. The growth rate of methane concentrations continued to be depressed, however, leaving behind a scientific puzzle. Some scientists theorize that global cooling from the vast quantities of sulfate aerosols deposited in the atmosphere by the eruption of Mount Pinatubo, in the Philippines, has stimulated absorption mechanisms. ${ }^{8}$ However, this remains at best an educated guess, and the most that can be said is that the carbon cycle contains forces that are as yet poorly understood.

In the case of methane, recent isotope studies suggest that the reduction is more likely to have been caused by a reduction in emissions than by an increase in absorption. Declining methane concentrations observed at stations in the high arctic suggest that a sharp reduction in methane leakage from pipeline systems in the former Soviet Union may be a contributing cause. ${ }^{9}$

\section{Global Climate Change Policy Developments}

Rising concentrations of carbon dioxide in the atmosphere were first detected in the late 1950s. Observations of atmospheric concentrations of methane, nitrous oxide, and other gases began in the late 1970s. However, concern about the effects of rising atmospheric concentrations of greenhouse gases remained largely the province of atmospheric scientists and climatologists until the mid-1980s, when a series of international scientific workshops and conferences began to move the topic onto the agenda of United Nations specialized agencies, particularly, the World Meteorological Office. When the Montreal Protocol to control ozone-depleting substances was signed, in late 1987, a large cadre of scientists, diplomats, policymakers, and members of environmental groups who had participated in the development of the Ozone Treaty turned their attention to the issue of global climate change.

The IPCC was established under the auspices of the United Nations in late 1988, to accumulate available scientific research on climate change, and to provide scientific advice to policymakers. A series of international conferences provided impetus for an international treaty aimed at limiting the human impact on climate. In December 1990, the United Nations established the Intergovernmental Negotiating Committee for a Framework Convention on Climate Change (generally called the $\mathbb{N}$ ). Beginning in 1991, the INC hosted a series of negotiating sessions that culminated in the signing, by more than 160 countries, including the United States, of the Framework Convention on Climate Change in Rio de Janeiro on May 4, $1992 .{ }^{10}$ The objective of the Framework Convention ("the Rio Treaty") was to:

“... achieve ... stabilization of the greenhouse gas concentrations in the atmosphere at a level that would prevent dangerous anthropogenic interference with the climate system."11

The Framework Convention, as it emerged from the negotiations, was based on the concept of voluntary commitments by signatories to take steps to implement the objectives of the Convention. These steps, as described in the treaty, include national commitments to prepare and submit for review national action plans and periodic national emissions inventories.

The outgoing Bush Administration prepared a draft national action plan in December 1992. ${ }^{12}$ On April 21, 1993 (Earth Day), President Clinton committed the United States to stabilizing its emissions of greenhouse gases at 1990 levels by the year 2000. The methods proposed by the Government to achieve this objective were described in the President's Climate Change Action Plan, published in October 1993. ${ }^{13}$ That document spells out a range of largely voluntary programs intended to achieve the stabilization objective. More detail-oriented readers may wish to consult the Technical Supplement to the Plan, published in early 1994, which spells out the assumptions underlying the Plan in greater detail. ${ }^{14}$

\footnotetext{
${ }^{8}$ K. Leutwyler, "No Global Warming?" Scientific American (February 1994), p. 24.

${ }^{9} \mathrm{M}$. Prather et al., "Other Trace Gases and Atmospheric Chemistry," in Intergovernmental Panel on Climate Change, Climate Change 1994: Radiative Forcing of Climate Change (Cambridge, UK: Cambridge University Press, 1995), pp. 87-88.

${ }^{10}$ This discussion draws on D. Bodanzky, "Prologue to the Climate Convention," in I. Minter and J.A. Leonard (eds.), Negotiating Climate Change: The Inside Story of the Rio Convention (Cambridge, UK: Cambridge University Press, 1994), pp. 49-66.

${ }^{11}$ United Nations, "Report of the Intergovernmental Negotiating Committee for a Framework on Convention on Climate Change on the Work of the Second Part of Its Fifth Session, Held at New York From 30 April to 9 May 1992," UN Document A/AC.237/18, Part II (May 15, 1992).

${ }^{12}$ U.S. Department of State, National Action Plan for Global Climate Change, Publication 10026 (Washington, DC, December 1992).

${ }^{13}$ President William J. Clinton, The Climate Change Action Plan (Washington, DC, October 1993), p. i.

${ }^{14}$ U.S. Department of Energy, The Climate Change Action Plan: Technical Supplement, DOE/PO-0011 (Washington DC, March 1994).
} 


\section{U.S. Emissions in an International Perspective}

The United States is the world's largest single emitter of carbon dioxide, accounting for about 23 percent of energy-related carbon emissions. The U.S. share of methane and nitrous oxide emissions, although uncertain, is likely to be much lower than its share of carbon dioxide emissions, as the principal sources of methane and nitrous oxide emissions are more common outside than within the United States. In the case of halocarbons and other gases, the U.S. share is likely to be considerably larger than 23 percent, because the use of cooling and refrigeration equipment is probably much more pervasive in the United States than elsewhere in the world.

In recent decades, the carbon dioxide emissions of North America and Western Europe have been growing relatively slowly (Figure 2). The worldwide growth in energy-related carbon dioxide emissions has come from

Figure 2. Energy-Related Carbon Emissions by Region, 1950-1993

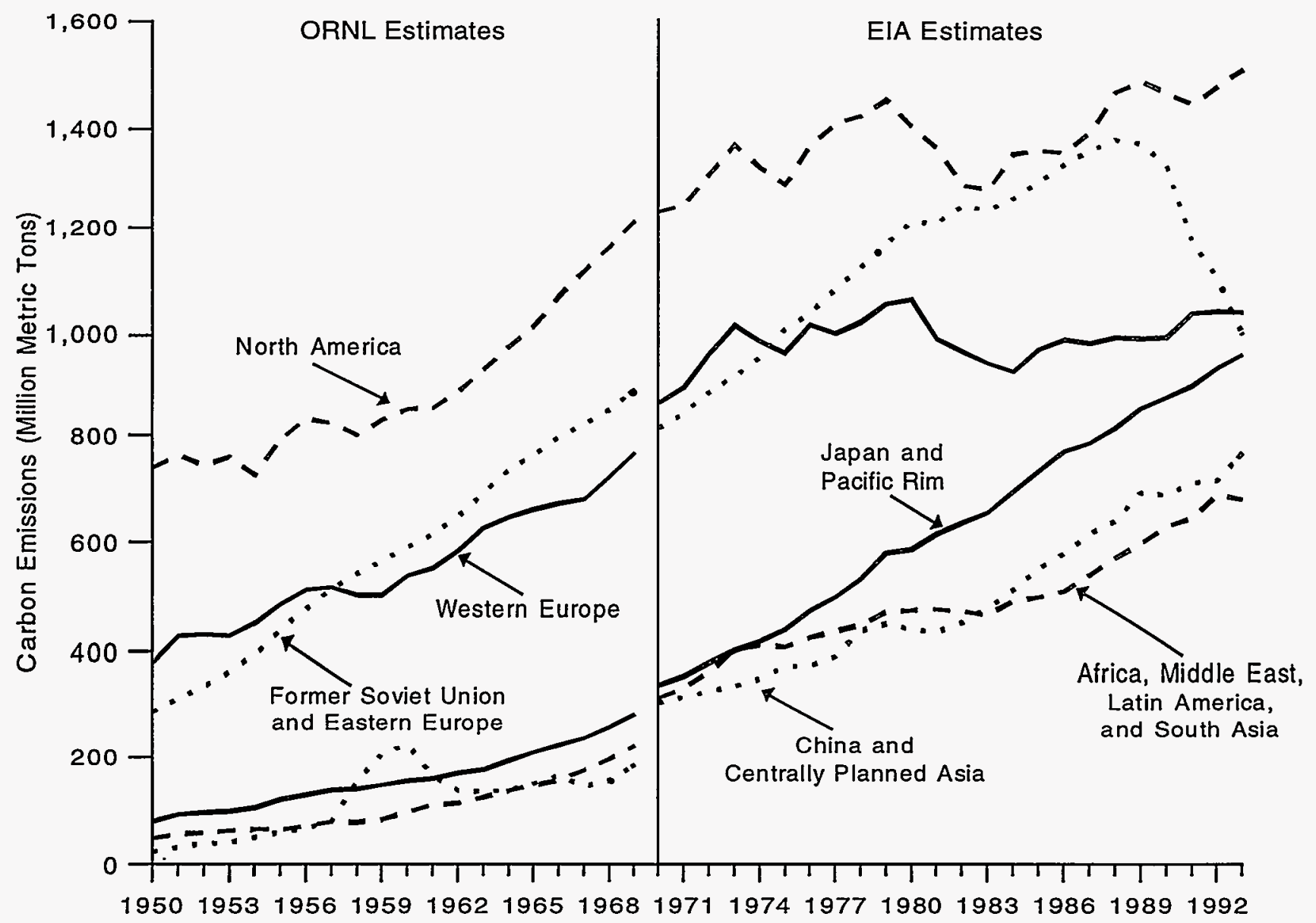

Note: Pre- and post-1970 emissions estimates differ in several minor ways: East Germany is included in "Former Soviet Union/Eastern Europe" prior to 1970, and in "Western Europe" after 1970. The two estimates may also use slightly different definitions of energy consumption, countries included in each region, and emissions coefficients. Pre-1970 estimates also include natural gas flaring and cement production, whereas post-1970 estimates exclude these sources.

Source: Emissions prior to 1970 from T.A. Boden, R.J. Stepanski, and F.W. Stoss, Trends '91: A Compendium of Data on Global Change, ORNL/CDIAC-46 (Oak Ridge, TN: Oak Ridge National Laboratory, December 1991), pp. 379-429. Emissions after 1970 were estimated by the Energy Information Administration, based on world energy consumption as reported in Energy Information Administration, International Energy Annual, DOE/EIA-0219 (Washington, DC, various years). 
rapid growth in the developing world and in the former centrally planned economies. The most striking development of recent years has been the rapid reduction in energy consumption (and hence carbon emissions) in the countries of the former Soviet Union and Eastern Europe, where emissions dropped by more than 20 percent between 1989 and 1992 and have continued to decline through 1993. Emissions reductions in former communist countries have been sufficient to stabilize world energy-related carbon dioxide emissions at 1990 levels through 1993, despite continuing rapid growth in the developing world and slow growth in the United States and Europe.
This year, the EIA released a projection of worldwide carbon emissions estimates in its International Energy Outlook $1995 .^{15}$ That projection indicates that the postcommunist decline in energy consumption is a one-time phenomenon, and that energy consumption in these countries will "bottom out" in the next few years and begin to rise again. Since the EIA also expects rapid growth in energy consumption in the developing world to continue, the prospect is for continued growth in worldwide carbon emissions.

${ }^{15}$ Energy Information Administration, International Energy Outlook 1995, DOE/EIA-0484(95) (Washington, DC, June 1995). 


\section{Carbon Dioxide Emissions}

\section{Overview}

U.S. carbon dioxide emissions are mostly ( 98.5 percent) accounted for by the combustion of fossil fuels, such as coal, natural gas, and petroleum. Because fossil fuels are of considerable economic value and their consumption is carefully monitored, energy-related carbon dioxide emissions can be estimated more reliably than any other emissions source. Table 4 shows trends in U.S. carbon dioxide emissions estimated in million metric tons of carbon. Carbon units can be converted to carbon dioxide (at full molecular weight) by multiplying by 3.667. Between 1993 and 1994, emissions rose by 1.7 percent, to 1,430 million metric tons. Carbon dioxide emissions associated with the transportation sector's consumption accounted for nearly one-half of the 20million-ton increase in energy-related carbon emissions, and the industrial and commercial sectors accounted for most of the balance (Table 5).

\section{Energy Consumption}

\section{Emissions Trends}

Over the long term, the level of U.S. energy-related carbon dioxide emissions can be viewed as the outcome of the interaction among three interrelated sets of factors:

- The growth of U.S. energy consumption, which is determined by, among other things, the rate of economic growth, changes in energy prices, weather fluctuations, and the rate of increase in the efficiency with which the economy uses energy.

- Within energy consumption, the division between the use of fossil fuels and nonfossil fuels (since hydroelectric and nuclear power do not directly produce carbon emissions). For example, during the 1980s, long-delayed nuclear capacity came on line

Table 4. U.S. Carbon Dioxide Emissions from Energy and Industry, 1987-1994 (Million Metric Tons of Carbon)

\begin{tabular}{|c|c|c|c|c|c|c|c|c|}
\hline Fuel Type or Process & 1987 & 1988 & 1989 & 1990 & 1991 & 1992 & 1993 & P1994 \\
\hline \multicolumn{9}{|l|}{ Energy Consumption } \\
\hline Petroleum & 576.1 & 601.6 & 601.2 & 589.4 & 569.9 & 581.3 & 582.9 & 596.8 \\
\hline Coal ..... & 454.0 & 479.2 & 479.8 & 481.5 & 475.7 & 478.5 & 494.6 & 496.8 \\
\hline Natural Gas & 251.9 & 263.1 & 274.8 & 273.4 & 279.1 & 286.5 & 296.9 & 302.6 \\
\hline $\begin{array}{l}\text { Total Energy Consumption . } \\
\text { Adjustments to U.S. Energy }\end{array}$ & $1,282.0$ & $1,344.0$ & $1,355.8$ & $1,344.2$ & $1,324.6$ & $1,346.3$ & $1,372.5$ & $1,396.2$ \\
\hline U.S. Territories . . . . . . . & 10.0 & 8.5 & 9.4 & 9.3 & 10.9 & 9.6 & 10.0 & 10.0 \\
\hline Unmetered Gas & 5.1 & 5.2 & 1.8 & 1.0 & 6.0 & 5.9 & 4.9 & 4.6 \\
\hline Total Adjustments & 15.2 & 13.7 & 11.2 & 10.2 & 16.9 & 15.5 & 14.9 & 14.6 \\
\hline Other Sources & & & & & & & & \\
\hline Cement Production & 8.6 & 8.7 & 8.7 & 8.8 & 8.5 & 8.6 & 9.1 & 9.5 \\
\hline Other Industrial . . . . . . . . . & 7.5 & 8.1 & 8.3 & 8.3 & 8.3 & 8.3 & 8.2 & 8.2 \\
\hline Gas Flaring $\ldots$. & 1.4 & 1.7 & 1.7 & 1.8 & 2.1 & 2.1 & 1.4 & 1.5 \\
\hline $\begin{array}{r}\text { Total Other Sources } \ldots \ldots \ldots \\
\text { Total } \ldots \ldots\end{array}$ & $\begin{array}{r}17.6 \\
1,314.7\end{array}$ & $\begin{array}{r}18.5 \\
1,376.2\end{array}$ & $\begin{array}{r}18.7 \\
1,385.6\end{array}$ & $\begin{array}{r}18.9 \\
1,373.3\end{array}$ & $\begin{array}{r}18.9 \\
1,360.4\end{array}$ & $\begin{array}{r}18.9 \\
1,380.8\end{array}$ & $\begin{array}{r}18.7 \\
1,406.2\end{array}$ & $\begin{array}{r}19.2 \\
1,430.0\end{array}$ \\
\hline
\end{tabular}

$P=$ preliminary data.

Notes: Data in this table are revised from the data contained in the previous EIA report, Emissions of Greenhouse Gases in the United States 1987-1992, DOE/EIA-0573 (Washington, DC, November 1994). Emissions coefficients are annualized for coal, motor gasoline, liquefied petroleum gases, jet fuel, and crude oil. Includes emissions from bunker fuels. Totals may not equal sum of components due to independent rounding.

Source: EIA estimates documented in this chapter. 
Table 5. U.S. Carbon Dioxide Emissions from Fossil Energy Consumption by End-Use Sector, 1987-1994 (Million Metric Tons of Carbon)

\begin{tabular}{|c|c|c|c|c|c|c|c|c|}
\hline End Use & 1987 & 1988 & 1989 & 1990 & 1991 & 1992 & 1993 & P1994 \\
\hline \multicolumn{9}{|l|}{ Energy Consumption } \\
\hline Residential & 251.0 & 264.8 & 267.5 & 253.0 & 257.1 & 255.9 & 271.6 & 271.6 \\
\hline Commercial & 197.2 & 207.6 & 210.0 & 206.7 & 206.4 & 205.5 & 212.1 & 216.9 \\
\hline Industrial & 422.7 & 444.1 & 445.6 & 452.4 & 436.6 & 453.6 & 454.0 & 461.4 \\
\hline Transportation & 411.1 & 427.5 & 432.7 & 432.1 & 424.5 & 431.4 & 436.7 & 446.3 \\
\hline Total Energy & $1,282.0$ & $1,344.0$ & $1,355.8$ & $1,344.2$ & $1,324.6$ & $1,346.3$ & $1,372.5$ & $1,396.2$ \\
\hline Electric Utility ${ }^{\mathrm{a}} \ldots$ & 452.6 & 475.9 & 483.5 & 476.9 & 473.5 & 472.9 & 490.6 & 494.9 \\
\hline
\end{tabular}

${ }^{a}$ Estimates of additional carbon dioxide emissions from the use of flue gas desulfurization are included in Table 13.

$P=$ preliminary data.

Notes: Includes energy from petroleum, coal, and natural gas. Electric utility emissions are distributed across consumption sectors.

Data in this table are revised from the data contained in the previous EIA report, Emissions of Greenhouse Gases in the United States 1987-1992, DOE/EIA-0573 (Washington, DC, November 1994). Totals may not equal sum of components due to independent rounding.

Source: EIA estimates documented in this chapter.

and contributed to an increased share of energy provided by nonfossil fuel sources.

- Within fossil energy consumption, the division between types of fossil fuels, since coal produces almost twice the carbon emissions per unit of energy that natural gas does, while petroleum products occupy an intermediate position. Growth in energy provided by coal consumption tapered off in the late 1980s, while natural gas consumption expanded to reach levels not attained since the 1970s.

During the 1990-1994 period, energy consumption in the United States has lagged behind economic growth (Figure 3). The U.S. economy grew at an average annual rate of 2.0 percent over the period 1990-1994, while energy consumption increased at a lower rate of 1.3 percent. The shifting composition of energy consumption has caused U.S. energy-related carbon emissions to lag behind energy consumption, growing at an average annual rate of 1 percent.

Between 1990 and 1994, U.S. total carbon dioxide emissions increased by a total of 57 million metric tons of carbon, or 4.1 percent. Emissions from natural gas consumption (Figure 4) accounted for a major portion of this increase (29.2 million metric tons); however, this is less than if the additional energy had been provided by coal, which contains more carbon per unit of energy supplied. To demonstrate, in 1994, if the additional energy provided by natural gas had been provided by coal, emissions of carbon dioxide probably would have been 3.5 to 4 million tons higher than they were.
Table 5 illustrates the sectoral composition of carbon dioxide emissions. The transportation and industrial sectors each account for about one-third of total emissions. Emissions from the transportation sector are growing more rapidly, because demand for motor gasoline, jet fuel, and diesel fuel is expanding. Although efficiency improvements have curtailed some growth, the growing popularity of luxury cars, trucks, and recreational vehicles effectively stabilized the U.S. average fuel economy at nearly 17 miles per gallon for all motor vehicles; in 1993 this measure actually worsened slightly. ${ }^{16}$ Energy consumption for the transportation sector in 1994 was 3 percent greater than in 1990.

The largest energy-consuming sector in the economy involves industrial activity. Overall energy consumption grew slightly between 1993 and 1994, by about 0.5 percent. Industrial sector energy consumption was only slightly higher in 1994 than in 1980. The residential and commercial sectors are smaller sources of emissions (Figure 5). The residential sector accounts for about 19 percent of U.S. carbon emissions and the commercial sector for about 15 percent. Over time, commercial sector energy consumption and emissions have grown with the expansion of the service sector in the U.S. economy. Commercial energy consumption was 28 percent higher in 1994 than in 1980.

For analytical purposes, carbon dioxide emissions from electric utilities were distributed over the end-use sectors in proportion to the amount of electricity consumed in each sector. However, trends in emissions from electric utilities can be considered independently.

${ }^{16}$ Energy Information Administration, Annual Energy Review 1994, DOE/EIA-0384(94) (Washington, DC, June 1995 ), p. 67. 
Figure 3. Indices of U.S. Gross Domestic Product, Population, Energy Consumption, and Carbon Dioxide Emissions, 1980-1994

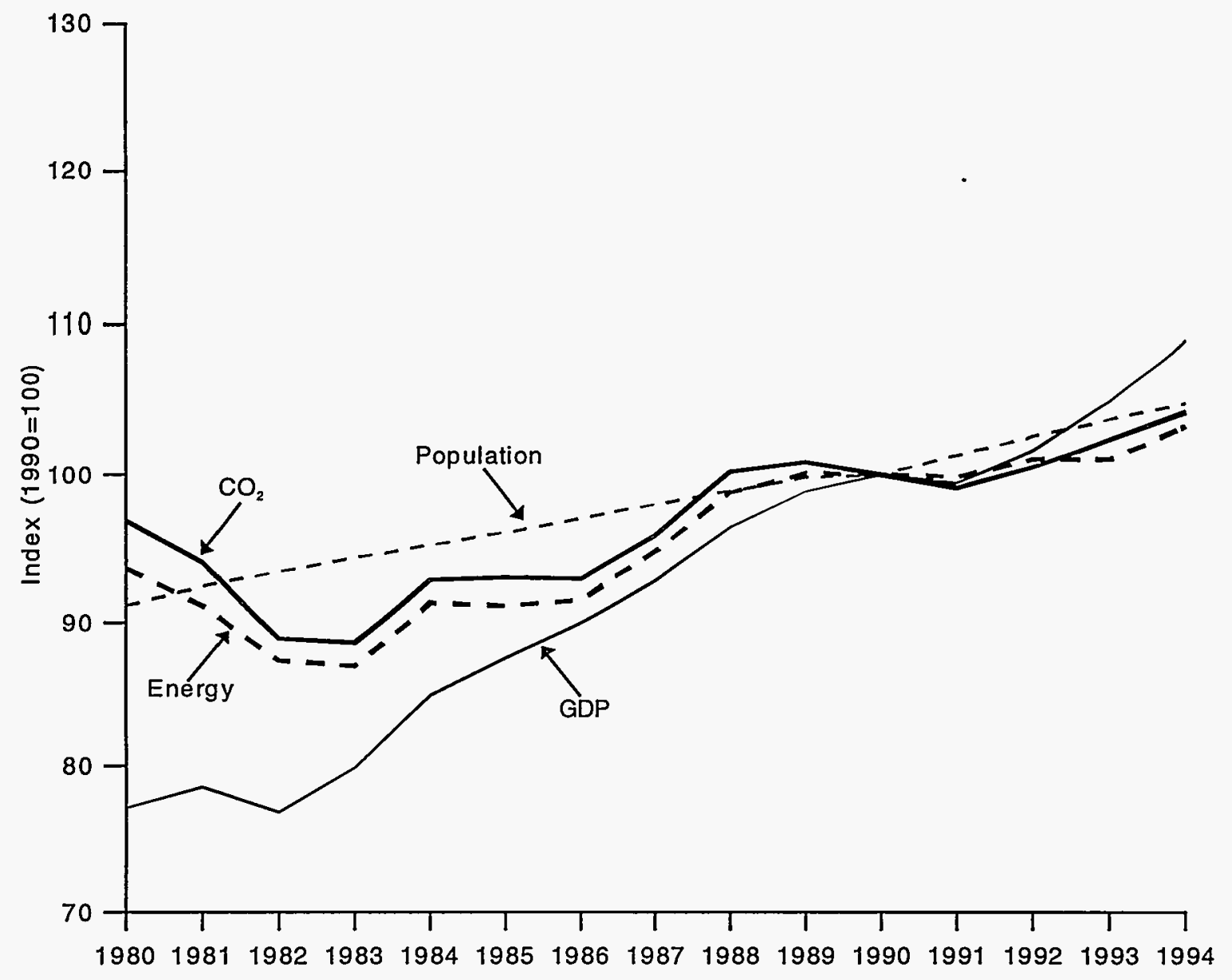

Following the world oil crises of 1974 and 1978, electric utilities in the United States switched from oil to other fuels, such as coal and nuclear power. By the early 1990s, however, trends had changed. Coal's share of electric utility generation stabilized at about 55 percent, while natural gas use grew, especially among independent power producers. Nuclear power also increased as new capacity came on line and capacity factors increased to 74 percent. In recent years, efficiency improvements (both on the supply side and on the demand side) have reduced emissions below levels that would otherwise have been reached. Reported energy savings from demand-side management programs in 1993 were about 45 trillion kilowatthours, equivalent to a little more than 1.5 percent of electric utility generation in the same year. ${ }^{17}$ This savings is equivalent to about 7.4 million metric tons of carbon per year.

Renewable fuels currently account for about 7 percent of total U.S. energy consumption. ${ }^{18}$ Conventional hydroelectric power (which emits no carbon) is the largest single source of renewable energy-supplying nearly half the energy provided by renewables in the early 1990s. Biofuels, which are dominated by wood but

\footnotetext{
${ }^{17}$ Energy Information Administration, U.S. Electric Utility Demand-Side Management, DOE/EIA-0589(93) (Washington, DC, July 1995), p. viii.

${ }^{18}$ Energy Information Administration, Annual Energy Review 1994, DOE/EIA-0384(95) (Washington, DC, July 1995$)$, pp. 9, 279.
} 
Figure 4. U.S. Energy-Related Carbon Dioxide Emissions by Fuel, 1980-1994

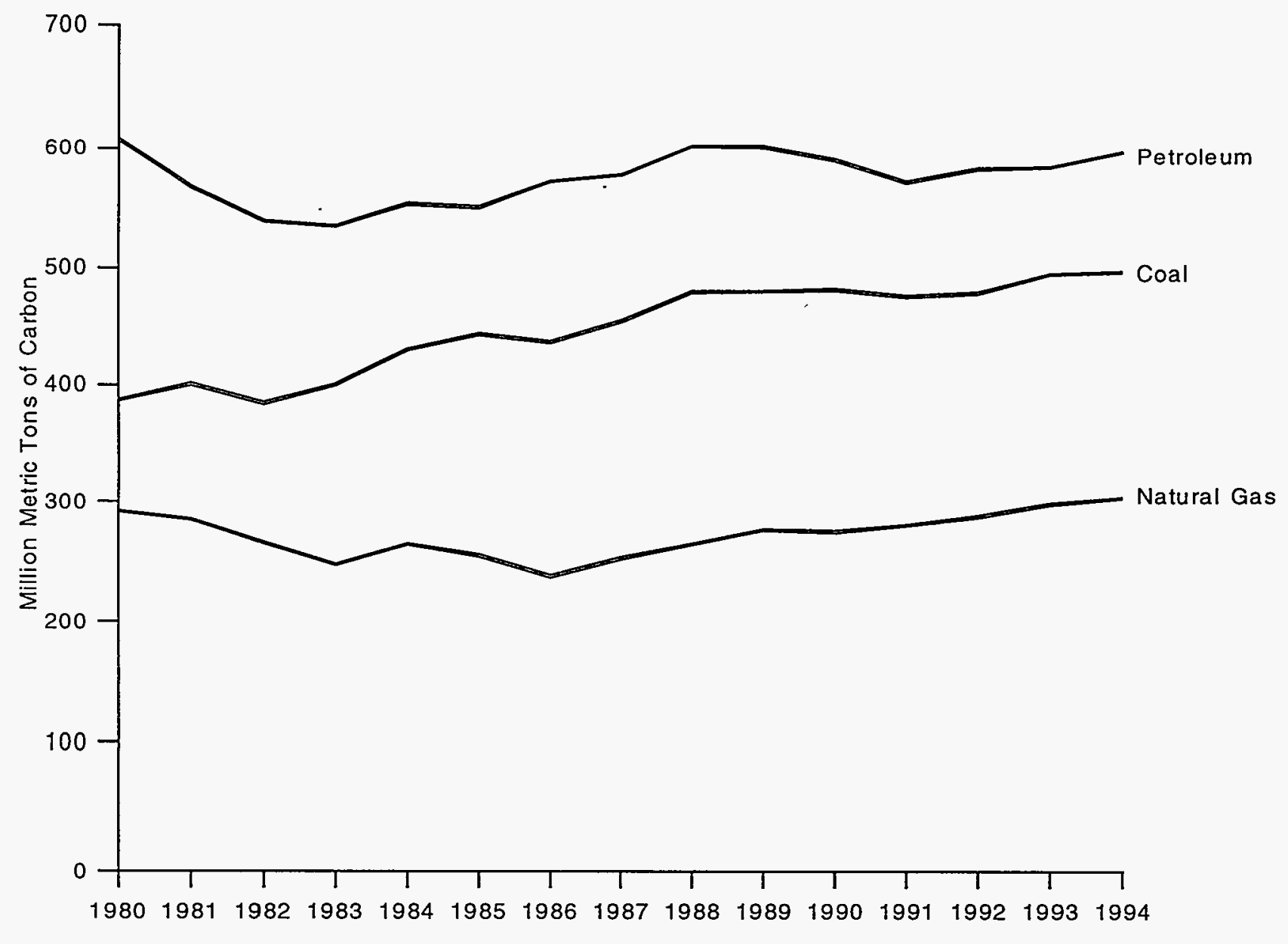

Source: ElA estimates presented in this chapter.

also include municipal solid waste and alcohol fuels, collectively account for another major portion of renewable energy. Biofuels emit carbon when burned, but, by convention, emissions from biofuels are presumed to substitute for natural decomposition, and consequently to result in no net increase in emissions. Reported consumption of the remaining renewables (geothermal, solar, and wind) altogether amounts to less than 5 percent of renewable energy consumption and 0.3 percent of total U.S. energy.

\section{Estimating Emissions}

Carbon emissions in this report were calculated by multiplying energy consumption for each fuel type by an associated carbon emissions coefficient. The result was then modified by subtracting carbon sequestered by nonfuel use. This section describes the derivation of information on energy consumption, emissions coefficients, and carbon sequestered by nonfuel use.

Sources of Energy Consumption. The energy consumption data used to make the estimates provided in this report were taken from EIA's State Energy Data Report 1993: Consumption Estimates, where they are detailed by end-use sector (residential, commercial, industrial, and transportation), by fuel type (petroleum [distinguishing 11 products], coal, natural gas, and electricity), and by year. Estimates for 1994 were derived from data in the Monthly Energy Review and Petroleum Supply Monthly. ${ }^{19}$ Industrial coal consumption, disaggregated by type,

${ }^{19}$ For 1980-1993, see Energy Information Administration, State Energy Data Report 1993: Consumption Estimates, DOE/EIA-0214(93) (Washington, DC, July 1995). For 1994 preliminary estimates, see Energy Information Administration, Monthly Energy Review, DOE/EIA-0035 (95/07) (Washington, DC, July 1995), and Petroleum Supply Annual 1994, Vol. 1, DOE/EIA-0340(94)/1 (Washington, DC, May 1995), p. 34. 


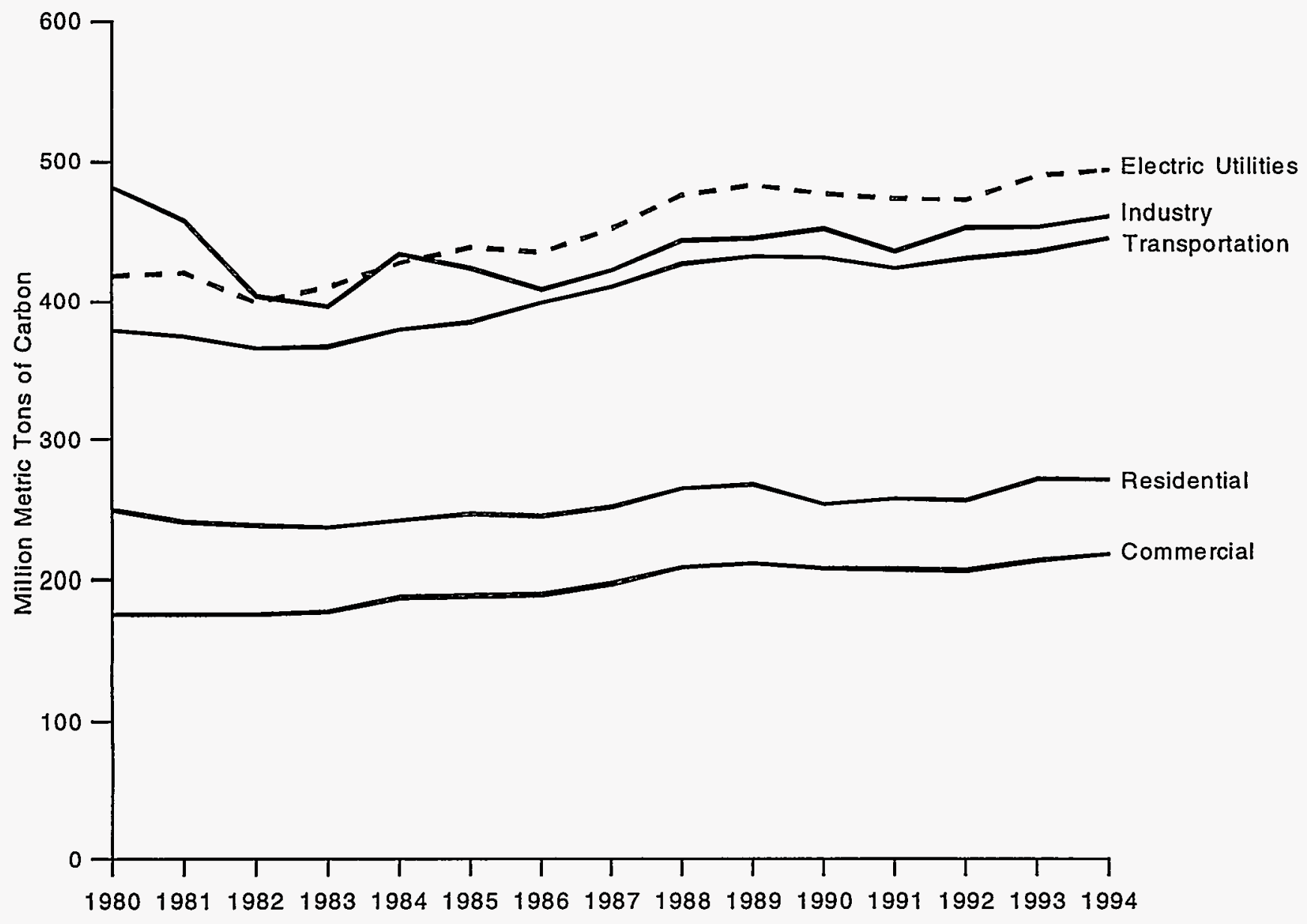

Note: Electric utility emissions are distributed across end-use consumption sectors. They are shown separately here only for independent analysis. See Appendix C, Tables C1-C5, for a detailed accounting of the distribution.

Source: EIA estimates presented in this chapter.

was derived from receipts by subsector published in EIA's Quarterly Coal Report. ${ }^{20}$

Emissions Coefficients. The amount of carbon released when a fossil fuel is burned depends on the density, carbon content; and gross heat of combustion of the fuel. ${ }^{21}$ This year, the ELA conducted a review of its assumptions about coefficients for estimating U.S. carbon emissions. Most of the coefficients for major fuels remained largely unchanged. The most significant changes were for motor gasoline, liquefied petroleum gases (LPG), jet fuel, and crude oil (Table 6). For each of these fuels EIA developed an annualized carbon emissions coefficient to reflect changes in chemical composition or product mix over the years. Below is a short description of what is included in the new

\footnotetext{
${ }^{20}$ Energy Information Administration, Quarterly Coal Report, DOE/EIA-0121 (Washington, DC, various issues).

${ }^{21}$ Combustion of hydrocarbons results in the production of carbon dioxide, water vapor, and heat. In the United States, the heat resulting from combustion is generally measured as the heat associated with production of water vapor and carbon dioxide. This is commonly referred to as the "higher" or "gross" heating value and is used in EIA statistics on thermal energy. The estimates in this report consistently employ coefficients that reflect the higher heating value assumption. Internationally, however, the "lower" heating value is used. If the lower heating value were used, the Btu content of the fuel would be 5 to 10 percent lower, and the coefficients would be 5 to 10 percent larger, but the carbon emissions estimate would be unchanged. This is sometimes a source of discrepancy. See OECD, Estimation of Greenhouse Gas Emissions and Sinks (Final Report) (Paris, France, August 1991), pp. 2-12-2-15.
} 
Table 6. Comparison of ElA Estimates of Carbon Emissions Coefficients at Full Combustion, 1987-1994 (Million Metric Tons per Quadrillion Btu)

\begin{tabular}{|c|c|c|c|c|c|c|c|c|c|}
\hline Factors & $\begin{array}{c}\text { EIA } \\
1994\end{array}$ & \multicolumn{8}{|c|}{ EIA 1995} \\
\hline Motor Gasoline & 19.41 & 19.38 & 19.39 & 19.41 & 19.41 & 19.41 & 19.42 & 19.43 & 19.43 \\
\hline Jet Fuel & 19.74 & 19.42 & 19.42 & 19.41 & 19.40 & 19.40 & 19.39 & 19.37 & 19.34 \\
\hline Crude Oil ............ & 20.29 & 20.13 & 20.16 & 20.13 & 20.16 & 20.18 & 20.22 & 20.23 & 20.21 \\
\hline
\end{tabular}

Sources: EIA 1994-Energy Information Administration, Emissions of Greenhouse Gases in the United States 1987-1992, DOE/EIA-0573 (Washington, DC, November 1994). ElA 1995-Estimates documented in Appendix A of this report.

coefficients. Appendix A contains a more detailed discussion of the methodology for developing the coefficients. Table A1 presents a full listing of all factors for crude oil, natural gas, and the complete slate of petroleum products.

- Motor Gasoline. Motor gasoline consumption is the single most significant source of anthropogenic carbon emissions in the United States. For this report, EIA expanded upon earlier analyses to annualize the coefficient for motor gasoline to capture the long-term change in density of this fuel. Although the difference between using a general coefficient and a set of annualized coefficients makes a minimal difference in current estimates, it is expected to be useful in capturing the consequences of the ongoing shift to reformulated gasoline.

- Liquefied Petroleum Gas. LPG covers a mix of products (principally, ethane, propane, butane, and isobutane). Annualizing the coefficient more accurately reflects the year-to-year shifts in product mix, although the net effect on emissions calculations is slight.

- Jet Fuel. Most of the jet fuel consumed in the United States is the kerosene type; the naphtha type (mostly consumed by the military) makes up the remainder. The annualized coefficient is necessary to reflect the military conversion from naphtha-based $\mathrm{JP}-4$ to kerosene-based JP-8 jet fuel. In addition, since the last issue of this report, the EIA has obtained better data on fuel composition, so that the coefficient is now given as between 19.34 and 19.45 million metric tons per quadrillion Btu, a level somewhat lower than the 19.74 used previously.

- Crude Oil. The annualized coefficient, presented here, reflects long-term shifts in the quality of crude oil input to U.S. refineries. The average density of crude oil refined in the United States declined from
33.74 degrees to 31.39 , or by about 7 percent, between 1981 and 1994. The average sulfur content increased from 0.87 to 1.14 percent over the same period. When these and other factors are considered, the annual emissions coefficient for crude oil moves from a low of around 19.94 million metric tons per quadrillion Btu in 1981 to 20.23 million metric tons per quadrillion Btu in the mid-1990s. Previously, EIA's estimates were based on a crude oil coefficient of 20.29 million metric tons per quadrillion Btu. Since the EIA estimates emissions on the basis of end-use consumption of refined products, and only tiny amounts of crude oil are consumed by end users, use of these annualized factors results in minimal changes to EIA's estimates.

Carbon Sequestration. After energy consumption was multiplied by the emissions coefficients shown in Appendix A, Table A1, carbon sequestered through nonfuel use was then deducted from gross carbon emissions. Estimates of nonfuel use of fossil fuels were based on data provided in EIA's Annual Energy Review 1994, Table 1.15, "Fossil Fuel Consumption for Nonfuel Use, 1980-1994."22 Table 7 lists nonfuel use of fossil fuels by product type. Most nonfuel use of energy occurs in the industrial sector. Nonfuel use of energy was about 5.24 quadrillion Btu in 1994 (Table 7).

Not all nonfuel use of fossil fuels results in carbon sequestration. For example, natural gas (predominantly methane, or $\left.\mathrm{CH}_{4}\right)$ is used as a feedstock to make ammonia $\left(\mathrm{NH}_{4}\right)$. The carbon in the methane is reformed into carbon dioxide and emitted into the atmosphere. On the other hand, petrochemical feedstocks, such as ethane, are made into ethylene and ultimately into polyethylene plastics and numerous other products. The carbon in these products ultimately is sequestered in landfills. Ideally, nonfuel use of fossil fuels would be divided into its constituent applications, and each application would be studied to determine the ultimate

${ }^{22}$ This information is currently available only at the national level and for 1980-1994. 
Table 7. U.S. Fossil Fuel Consumption for Nonfuel Use, 1987-1994

(Quadrillion Btu)

\begin{tabular}{|c|c|c|c|c|c|c|c|c|}
\hline End Use & 1987 & 1988 & 1989 & 1990 & 1991 & 1992 & 1993 & P1994 \\
\hline \multicolumn{9}{|l|}{ Petroleum } \\
\hline Asphalt and Road Oil & 1.13 & 1.14 & 1.10 & $1: 09$ & 1.08 & 1.10 & 1.15 & 1.17 \\
\hline Liquefied Petroleum Gases . . . . . . . & 1.12 & 1.21 & 1.26 & 1.28 & 1.42 & 1.45 & 1.60 & 1.73 \\
\hline Lubricants & 0.35 & 0.35 & 0.35 & 0.37 & 0.33 & 0.33 & 0.34 & 0.35 \\
\hline Industrial & 0.18 & 0.18 & 0.18 & 0.19 & 0.17 & 0.17 & 0.17 & 0.18 \\
\hline Transportation & 0.17 & 0.17 & 0.17 & 0.18 & 0.16 & 0.16 & 0.16 & 0.17 \\
\hline Petrochemical Feed & 1.00 & 1.00 & 1.00 & 0.82 & 1.15 & 1.20 & 1.21 & 1.24 \\
\hline Petroleum Coke & 0.14 & 0.15 & 0.14 & 0.19 & 0.16 & 0.26 & 0.18 & 0.18 \\
\hline Special Naphtha & 0.14 & 0.11 & 0.11 & 0.11 & 0.09 & 0.10 & 0.10 & 0.08 \\
\hline Other (Waxes and Misc.). & 0.23 & 0.24 & 0.25 & 0.23 & 0.26 & 0.21 & 0.20 & 0.22 \\
\hline Coal $\ldots \ldots \ldots \ldots \ldots \ldots \ldots$ & 0.03 & 0.02 & 0.02 & 0.02 & 0.02 & 0.02 & 0.02 & 0.02 \\
\hline Natural Gas to Chemical Plants .... & 0.26 & 0.29 & 0.30 & 0.29 & 0.22 & 0.24 & 0.25 & 0.27 \\
\hline Total $\ldots \ldots \ldots \ldots \ldots \ldots \ldots$ & 4.40 & 4.51 & 4.53 & 4.41 & 4.74 & 4.91 & 5.05 & 5.24 \\
\hline
\end{tabular}

$P=$ preliminary data.

Notes: Asphalt and lubricants are as reported in State Energy Data Report 1993, DOE/EIA-0214(93) (Washington, DC, July 1995). Some slight differences exist between this table and the Annual Energy Review. Data in this table are revised from the data contained in the previous EIA report, Emissions of Greenhouse Gases in the United States 1987-1992, DOE/EIA-0573 (Washington, DC, November 1994).

Source: Energy Information Administration, Annual Energy Review 1994, DOE/EIA-0384(94) (Washington, DC, July 1995), Table 1.15, p. 33, and underlying estimates.

fate of the carbon in the fossil fuel. It has not been possible to collect sufficient information this year to adopt this approach in other than a single case.

Instead, as was done last year, the EIA used the Intergovernmental Panel on Climate Change (IPCC) methods and information specific to U.S. industry to determine how much carbon was sequestered by each product shown in Table $7 .^{23} \mathrm{~A}$ "proportion of nonfuel use sequestered" was assumed for each product, usually based on IPCC recommendations but with EIA assumptions for those products for which no IPCC recommendation was available or for which more precise information could be obtained. These assumptions are shown in Table 8. The rationale for the assumptions made for some of the larger products is as follows:

- Asphalt and Road Oil. All carbon in the 1.17 quadrillion Btu of asphalt and road oil was presumed to be sequestered.

- Liquefied Petroleum Gas. This use is derived from sales of LPG (i.e., ethane, propane, butane, isobutane, and pentanes plus) to the chemical industry. For this amount (approximately 1.73 quadrillion Btu), the EIA assumed that 80 percent of the carbon was sequestered.
- Petrochemical Feedstocks. Petrochemical feedstocks include naphtha and other oils used as petrochemical feedstock, still gas not used as refinery fuel, and synthetic gas. This was about 1.2 quadrillion Btu of industrial energy consumption in 1994. Since some of these fuels are used to make products like plastic and rubber, in which carbon will be sequestered for long periods of time, the EIA assumed that 80 percent of the carbon in the feedstock is sequestered.

- Natural Gas. Nonfuel use of natural gas is based on estimates of natural gas feedstocks supplied to the chemical industry to manufacture ammonia (for fertilizer) and other chemicals. This use was about 0.56 quadrillion Btu in 1994. All the natural gas used to manufacture ammonia was assumed to be oxidized during the production process, while the carbon in other chemicals was assumed to be sequestered. Since the mix of these products can change from year to year, the effective sequestration rate also varies. Previously, this had been assumed to be a constant 33 percent, but actually it ranges from 41 to 55 percent in the United States.

To recapitulate, the nonfuel use of energy shown in Table 7 was multiplied by the emissions coefficients in

\footnotetext{
${ }^{23}$ For IPCC methodology see OECD, Estimation of Greenhouse Gas Emissions and Sinks (Final Report) (Paris, France, August 1991), pp. 2-20 and 2-21, as prepared for the IPCC.
} 
Table A1 and the proportion sequestered shown in Table 8 to determine the amount of carbon sequestered by nonfuel use. The results are shown in Table 9.

There is also a very small amount of carbon sequestration associated with the combustion of fossil fuels. Using IPCC assumptions, this report assumes that oxidation of liquid and solid fuels during combustion is 99 percent complete, and that 1 percent of the carbon remains sequestered. Oxidation of gaseous fuels (LPG and natural gas) is assumed to be 99.5 percent complete. ${ }^{24}$ Conceptually, fuel may be "lost" before combustion due to evaporation, leaks, or spills; it may be subject to incomplete combustion and vented to the atmosphere in the form of volatile organic compounds or particulates; or it may remain at the site of combustion in the form of carbon-containing ash or soot.

\section{Adjustments to U.S. Energy Consumption}

In recent years, there have been several estimates of U.S. carbon emissions, some of which differ by as much as 5 percent. Two significant reasons for the differences in emissions estimates (beyond those associated with differences in coefficients) are the definitions of "energy consumption" and "the United States" employed by researchers. Subtle differences in definition can produce variations of several percent in reported energy consumption, and hence in carbon emissions. Some agencies include U.S. territories, such as Puerto Rico, while others exclude U.S. territories. If consumption is estimated as "apparent consumption" based on production plus imports minus exports plus stock change, then statistical discrepancies will be included in consumption. International bunkers are sometimes counted as domestic consumption, and sometimes as exports. This section describes how each of these items is accommodated in this report.

\section{Energy Consumption in U.S. Territories}

EIA's energy data for the United States cover only the 50 States and the District of Columbia. In contrast, energy data produced by the International Energy Agency for the United States cover the 50 States plus U.S. territories, including Puerto Rico, the U.S. Virgin Islands, and Guam. The energy consumption of the U.S. territories is only about 0.5 quadrillion Btu. Because U.S. territories are all islands, their consumption consists primarily of petroleum products. For the territories
Table 8. Rates of Sequestration for U.S. Fossil Fuel Consumption

\begin{tabular}{|c|c|c|}
\hline Fuel Type & $\begin{array}{c}\text { Fraction } \\
\text { of Fuel } \\
\text { Combusted }\end{array}$ & $\begin{array}{c}\text { Fraction } \\
\text { of Nonfuel } \\
\text { Use of Energy } \\
\text { Sequestered }\end{array}$ \\
\hline \multicolumn{3}{|l|}{ Petroleum } \\
\hline Motor Gasoline & 0.99 & -- \\
\hline LPG $\ldots \ldots \ldots \ldots \ldots$ & 0.995 & 0.8 \\
\hline Jet Fuel $\ldots \ldots \ldots \ldots \ldots$ & 0.99 & -- \\
\hline Distillate Fuel . . . . . . . & 0.99 & -- \\
\hline Residual Fuel . . . . . . . & 0.99 & - \\
\hline Asphait and Road Oil .... & 0.99 & 1 \\
\hline Lubricants $\ldots \ldots \ldots \ldots$ & 0.99 & 0.5 \\
\hline Petrochemical Feed ..... & 0.99 & 0.8 \\
\hline Aviation Gas . . . . . . . . . & 0.99 & $\ldots$ \\
\hline Kerosene . . . . . . . . . & 0.99 & - \\
\hline Petroleum Coke ........ & 0.99 & 0.5 \\
\hline Special Naphtha . . . . . . . & 0.99 & 0 \\
\hline \multicolumn{3}{|l|}{ Other } \\
\hline \multicolumn{3}{|l|}{ Aviation Gas } \\
\hline Blending Components . . . . & 0.99 & -- \\
\hline Crude Oil . . . . . . . . . & 0.99 & - \\
\hline Naphtha $<401^{\circ} \mathrm{F} \ldots \ldots \ldots$ & 0.99 & 0 \\
\hline Other Oil $\geq 401^{\circ} \mathrm{F}$ & 0.99 & 0 \\
\hline \multicolumn{3}{|l|}{ Petrochemical Feed } \\
\hline Still Gas . . . . . . . . . . . & 0.99 & 0 \\
\hline \multicolumn{3}{|l|}{ Motor Gasoline } \\
\hline Blending Components . . . . & 0.99 & -- \\
\hline Miscellaneous . . . . . . . . & 0.99 & -- \\
\hline Natural Gasoline . . . . . . . & 0.99 & -- \\
\hline Plant Condensate . . . . . . & 0.99 & -- \\
\hline Pentanes Plus $\ldots \ldots \ldots$ & 0.99 & -- \\
\hline Still Gas . . . . . . . . . . & 0.99 & -- \\
\hline Special Naphthas . . . . . . & 0.99 & 0 \\
\hline Unfinished Oils . . . . . . . & 0.99 & - \\
\hline Unfractionated Stream ... & 0.99 & -- \\
\hline Waxes ............. & 0.99 & 0 \\
\hline \multicolumn{3}{|l|}{ Coal } \\
\hline Residential and Commercial & 0.99 & -- \\
\hline Industrial Coking . . . . . . . & 0.99 & 0.75 \\
\hline Industrial Other . . . . . . . & 0.99 & -- \\
\hline Electric Utility . . . . . . . & 0.99 & -- \\
\hline \multicolumn{3}{|l|}{ Natural Gas } \\
\hline Flare Gas . & 1 & -- \\
\hline Natural Gas . . . . . . . . & 0.995 & $0.41-0.55$ \\
\hline
\end{tabular}

Sources: ElA estimates documented in this chapter; and Intergovernmental Panel on Climate Change, Greenhouse Gas Inventory Reference Manual, IPCC Guidelines for National Greenhouse Gas Inventories, Vol. 3 (Paris, France, 1995), pp. 1.24-1.29.

as a group, oil consumption ranges between 200,000 and 250,000 barrels per day, and coal consumption averages about 300,000 short tons per year.

\footnotetext{
${ }^{24}$ Intergovernmental Panel on Climate Change, Greenhouse Gas Inventory Reference Manual, IPCC Guidelines for National Greenhouse Gas Inventories, Vol. 3 (Paris, France, 1995), p. 1.33.
} 
Table 9. U.S. Carbon Sequestered by Nonfuel Use of Energy, 1987-1994

(Million Metric Tons of Carbon)

\begin{tabular}{|c|c|c|c|c|c|c|c|c|}
\hline End Use & 1987 & 1988 & 1989 & 1990 & 1991 & 1992 & 1993 & P1994 \\
\hline \multicolumn{9}{|l|}{ Industrial } \\
\hline \multicolumn{9}{|l|}{ Petroleum } \\
\hline Liquefied Petroleum Gases . . . . . . . & 15.3 & 16.5 & 17.2 & 17.5 & 19.3 & 19.8 & 21.8 & 23.5 \\
\hline Asphalt and Road Oil ...... & 23.3 & 23.5 & 22.7 & 22.5 & 22.3 & 22.7 & 23.7 & 24.1 \\
\hline Lubricants ................ & 1.9 & 1.8 & 1.8 & 1.9 & 1.7 & 1.7 & 1.8 & 1.8 \\
\hline Other $\ldots \ldots \ldots \ldots \ldots \ldots \ldots$ & 22.0 & 22.3 & 22.4 & 19.9 & 25.2 & 26.4 & 25.3 & 26.0 \\
\hline Petrochemical Feed ... & 15.5 & 15.5 & 15.5 & 12.7 & 17.8 & 18.6 & 18.7 & 19.2 \\
\hline Petroleum Coke $\ldots \ldots \ldots \ldots \ldots$ & 1.9 & 2.1 & 1.9 & 2.6 & 2.2 & 3.6 & 2.6 & 2.5 \\
\hline Waxes and Misc. . . . . . . . . & 4.6 & 4.8 & 4.9 & 4.6 & 5.2 & 4.2 & 4.1 & 4.3 \\
\hline Coal . . . . . . . . . . & 0.6 & 0.4 & 0.4 & 0.4 & 0.4 & 0.4 & 0.4 & 0.4 \\
\hline Natural Gas ........... & 3.7 & 4.2 & 4.3 & 4.2 & 3.2 & 3.5 & 3.6 & 3.9 \\
\hline \multicolumn{9}{|l|}{ Transportation } \\
\hline Lubricants & 1.7 & 1.7 & 1.7 & 1.8 & 1.6 & 1.6 & 1.7 & 1.7 \\
\hline Total $\ldots \ldots \ldots \ldots \ldots \ldots \ldots$ & 68.5 & 70.4 & 70.5 & 68.1 & 73.7 & 76.0 & 78.2 & 81.4 \\
\hline
\end{tabular}

$P=$ preliminary data.

Note: Data in this table are revised from the data contained in the previous EIA report, Emissions of Greenhouse Gases in the United States 1987-1992, DOE/EIA-0573 (Washington, DC, November 1994).

Source: ElA estimates documented in this chapter.

Table 10 illustrates reported energy consumption in U.S. territories. These data have been published in EIA's International Energy Annual. This table also uses unpublished estimates of oil consumption for Wake Island, American Samoa, and the Pacific Trust Territories, which are included as "Other" in the Asia/ Pacific region in the International Energy Annual.

Energy consumption for U.S. territories was converted to carbon emissions using the same emissions coefficients applied to U.S. energy data. Carbon emissions for U.S. territories ranged from 9 to 11 million metric tons per year (Table 11). Because a large portion of reported energy consumption in U.S. territories was from "other petroleum," there is a degree of uncertainty about the correct emissions factor to be used in this area, as well as the reliability of underlying data.

\section{International Bunker Fuels}

The term "international bunker fuels" refers to fuel purchased by merchant ships in U.S. ports and by international air carriers. By convention, trade statistics treat sales of bunker fuels as exports by the selling country, because the purchaser promptly hauls the fuel outside national boundaries. This convention is followed by organizations that prepare international energy statistics, such as the United Nations and the International Energy Agency.

Bunkers, however, are an export without a corresponding import, because the purchasing ship generally burns the fuel on the high seas. EIA energy statistics, which are based on domestic sales of products, treat bunker fuels sales in the same way as sales of other fuels, i.e., as domestic energy consumption. Carbon emissions from bunker fuels are, therefore, already counted in the domestic energy consumption of the United States-primarily as transportation-related consumption of residual oil.

Those who wish to understand the differences between emissions inventories based on international energy statistics and EIA data will, however, need to know the amount of energy consumption and the amount of carbon emissions associated with international bunkers. Table 10 therefore shows U.S. international bunker fuel usage. ${ }^{25}$ The amount is about 1.1 quadrillion Btu (or 500,000 barrels per day), largely of residual oil; it accounts for emissions of about 19 to 24 million metric tons of carbon annually (Table 11).

${ }^{25}$ Up to 1990 , bunker fuel consumption was reported by the U.S. Department of Commerce, based on trade data. Since 1991 , bunker fuel data have been collected by the EIA, based on sales of specialized marine fuels by wholesalers. These data do not distinguish between international and domestic bunker fuel, nor do they provide for aviation bunkers. This year, international aviation bunkers and international marine bunkers were estimated on the basis of computations made by Oak Ridge National Laboratory in its Transportation Energy Data Book, Edition 13, p. A-5. International bunkers were assumed to account for 25 percent of marine distillate sales, 75 percent of marine fuel oil sales, and 15 percent of kerosene-based jet fuel sales. 
Table 10. Energy Consumption in U.S. Territories and International Bunkers, 1987-1994 (Quadrillion Btu)

\begin{tabular}{|c|c|c|c|c|c|c|c|c|}
\hline Place & 1987 & 1988 & 1989 & 1990 & 1991 & 1992 & P1993 & P1994 \\
\hline \multicolumn{9}{|l|}{ U.S. Territories } \\
\hline Puerto Rico & 0.34 & 0.30 & 0.30 & 0.29 & 0.37 & 0.31 & NA & NA \\
\hline Virgin Islands & 0.12 & 0.08 & 0.12 & 0.11 & 0.12 & 0.11 & NA & NA \\
\hline American Samoa & 0.01 & 0.01 & 0.01 & 0.01 & 0.01 & 0.01 & NA & NA \\
\hline Guam & 0.01 & 0.01 & 0.01 & 0.03 & 0.03 & 0.02 & NA & NA \\
\hline Micronesia & * & * & * & * & * & * & NA & NA \\
\hline Wake Island & 0.02 & 0.02 & 0.02 & 0.02 & 0.02 & 0.02 & NA & NA \\
\hline Total $\ldots . . \ldots \ldots$ & 0.49 & 0.42 & 0.46 & 0.46 & 0.54 & 0.47 & 0.50 & 0.50 \\
\hline U.S. Bunker Fuels . . . . . . . . . . . . . & 0.91 & 1.00 & 1.06 & 1.05 & 1.11 & 1.17 & 1.06 & NA \\
\hline
\end{tabular}

*Less than 5 trillion Btu.

$P=$ preliminary data. $N A=$ not available.

Notes: Energy consumption in Micronesia ranged from 0.002 to 0.004 quadrillion Btu. Data in this table are revised from the data contained in the previous ElA report, Emissions of Greenhouse Gases in the United States 1987-1992, DOE/EIA-0573 (Washington, DC, November 1994).

Sources: U.S. Territories: Energy Information Administration, International Energy Annual, DOE/EIA-0219 (various years), and unpublished data included in "Other" countries in the Asia/Pacific region. Data are shown in tables of "Apparent Consumption of Petroleum Products." Data for 1992 and 1993 based on unpublished preliminary information. Bunker Fuels: Jet Fuel一Oak Ridge National Laboratory, Transportation Energy Data Book (Oak Ridge, TN, various years); Distillate and Residual Fuel Oils, 19871990-Energy Information Administration, International Energy Annual, DOE/EIA-0219 (Washington, DC, 1987-1990); Distillate and Residual Fuel Oils, 1991-1993-Energy Information Administration, Fuel Oil and Kerosene Sales, DOE/ElA-0535 (Washington, DC, 1991-1993).

Table 11. Carbon Emissions from U.S. Territories, International Bunkers, and Unmetered Gas Consumption, 1987-1994

(Million Metric Tons of Carbon)

\begin{tabular}{|c|c|c|c|c|c|c|c|c|}
\hline Item & 1987 & 1988 & 1989 & 1990 & 1991 & 1992 & 1993 & P1994 \\
\hline U.S. Territories & 10.0 & 8.5 & 9.4 & 9.3 & 10.9 & 9.6 & 10.0 & 10.0 \\
\hline Bunker Fuels & 18.9 & 20.7 & 21.9 & 21.7 & 22.9 & 24.2 & 21.8 & NA \\
\hline Unmetered Natural Gas Consumption & 5.1 & 5.2 & 1.8 & 1.0 & 6.0 & 5.9 & 4.9 & 4.6 \\
\hline
\end{tabular}

$\mathrm{P}=$ preliminary data. $\mathrm{NA}=$ not available.

Note: Data in this table are revised from the data contained in the previous EIA report, Emissions of Greenhouse Gases in the United States 1987-1992, DOE/EIA-0573 (Washington, DC, November 1994).

Source: Estimates documented in this chapter.

\section{Unreported Natural Gas Consumption}

The "balancing item" in natural gas statistics produced by EIA represents the difference between reported supply and disposition of the gas. On an annual basis, the volume of natural gas distributed by suppliers has always been larger than that reportedly consumed. This discrepancy can be attributed to the effects of measurement errors, data reporting problems, pipeline leakage, and unreported consumption.

Repairing leaks has become a priority in pipeline operations, due to safety and liability concerns. For this reason, only 0.5 percent of natural gas consumption can be attributed to pipeline leakage. Leaked gas enters the atmosphere in the form of methane. (Estimates of methane emissions from natural gas leakage can be found in Chapter 3 of this report.) While measurement errors and data reporting problems certainly exist in the natural gas industry, these errors ought not to be "tilted" in the direction of gas supply unless there is unreported consumption. The EIA believes that the amount of gas in the "balancing item" less the amount lost to leakage is more likely than not to reflect unreported consumption.

Emissions from this source were estimated by first converting the volume of unmetered consumption into Btu, 
then multiplying by a carbon emissions coefficient. In 1994, unmetered consumption of 0.32 trillion cubic feet resulted in emissions of approximately 5 million metric tons of carbon (Table 12). Annually, emissions from unreported natural gas consumption tend to fall in the range of 4 to 6 million metric tons, with the exceptions of 1989 and 1990, when the "balancing item" for those years was significantly low.

\section{Energy Production}

U.S. energy production processes also generate small volumes of carbon dioxide emissions. The two principal sources of these emissions are flaring of natural gas and venting of the carbon dioxide that is produced in conjunction with natural gas. When a field is developed for petroleum extraction, any natural gas associated with that field may be flared if its use is not economically justifiable. This is typically the case with a remote site or when the gas is of poor quality or minimal volume. During natural gas production, flaring may be used for disposal of waste products (e.g., hydrogen sulfide), capacity testing, or as a result of process upsets.

This year, the method for estimating emissions from natural gas flaring has been modified and is now based on the volume of vented and flared gas reported to EIA by each State. This composite volume is scaled by a State-specific flaring percentage to ascertain the amount of natural gas flared in that State. The percent flared value is taken from a 1990 Department of Energy study that determined the relative split between venting and flaring for each State. ${ }^{26}$ To calculate carbon emissions, the State figures are aggregated, converted into Btu, and then multiplied by the emissions coefficient applicable to natural gas.

As Tables 4 and 13 indicate, natural gas flaring is a minor source of emissions, accounting for only 1.4 million metric tons of carbon in 1993. There is some uncertainty to these estimates given that operators in the field are not required to meter the amount of gas that is vented or flared. Further, methods used by States to determine their vented and flared statistics are not uniform.

\section{Industrial Sources}

In addition to energy-related emissions, carbon dioxide is also produced during industrial processes. The primary source of industrial emissions is limestone $\left(\mathrm{CaCO}_{3}\right)$ calcination to create lime $(\mathrm{CaO})$. These two compounds are basic materials in a variety of manufacturing processes, particularly, cement, iron and steel, and glass. Other sources of industrial emissions include the production and use of soda ash $\left(\mathrm{Na}_{2} \mathrm{CO}_{3}\right)$ and the manufacture of carbon dioxide and aluminum.

For this source category, emissions estimates are based on the compound used in the industrial process. By

Table 12. U.S. Natural Gas Consumption and Balancing Item, 1987-1994

\begin{tabular}{|c|c|c|c|c|c|c|c|c|}
\hline Item & 1987 & 1988 & 1989 & 1990 & 1991 & 1992 & 1993 & P1994 \\
\hline Gas Consumption (Trillion Cubic Feet) & 17.21 & 18.03 & 18.80 & 18.72 & 19.04 & 19.54 & 20.30 & 20.60 \\
\hline "Balancing Item" (Trillion Cubic Feet) & -0.44 & -0.45 & -0.22 & -0.15 & -0.50 & -0.51 & -0.41 & -0.39 \\
\hline Estimated Gas Leakage (Trillion Cubic Feet) & -0.07 & -0.07 & -0.07 & -0.07 & -0.07 & -0.07 & -0.07 & -0.07 \\
\hline Unmetered Consumption (Trillion Cubic Feet) & -0.37 & -0.38 & -0.15 & -0.08 & -0.43 & -0.44 & -0.34 & -0.32 \\
\hline $\begin{array}{l}\text { Estimated Unmetered Carbon Emissions } \\
\text { (Million Metric Tons) } \ldots \ldots \ldots \ldots \ldots \ldots \ldots\end{array}$ & 5.13 & 5.19 & 1.78 & 0.97 & 5.98 & 5.94 & 4.92 & 4.59 \\
\hline
\end{tabular}

$P=$ preliminary data.

Note: Data in this table are revised from the data contained in the previous EIA report, Emissions of Greenhouse Gases in the United States 1987-1992, DOE/EIA-0573 (Washington, DC, November 1994).

Sources: Energy Information Administration, Natural Gas Annual, DOE/EIA-0131 (Washington, DC, 1987-1993), and Natural Gas Monthly, DOE/EIA-0130(95/05) (Washington, DC, May 1995), p. 3. Leakage estimates from this report (see Chapter 3). All gas in the balancing item not attributed to leakage is assumed as unreported consumption.

\footnotetext{
${ }^{26}$ U.S. Department of Energy, An Evaluation of the Relationship Between the Production and Use of Energy and Atmospheric Methane Emissions, DOE/NBB-0088P (Washington, DC, April 1990). See Appendix C.
} 
Table 13. U.S. Carbon Dioxide Emissions from Gas Flaring, 1987-1994

\begin{tabular}{|c|c|c|c|c|c|c|c|c|}
\hline Item & 1987 & 1988 & 1989 & 1990 & 1991 & 1992 & 1993 & P1994 \\
\hline \multicolumn{9}{|l|}{ Basic Data } \\
\hline $\begin{array}{l}\text { Total Natural Gas Vented and Flared } \\
\text { (Billion Cubic Feet) } \ldots \ldots \ldots \ldots\end{array}$ & 85.80 & 102.18 & 101.56 & 111.08 & 127.64 & 124.23 & 86.94 & 89.80 \\
\hline $\begin{array}{l}\text { Btu Content of Flare Gas } \\
\text { (Btu per Cubic Foot) } \ldots\end{array}$ & 1,112 & 1,109 & 1,107 & 1,105 & 1,108 & 1,110 & 1,106 & 1,106 \\
\hline $\begin{array}{l}\text { Carbon Emissions from Flaring } \\
\text { (Million Metric Tons) } \ldots \ldots \ldots \ldots \ldots\end{array}$ & 1.42 & 1.69 & 1.68 & 1.83 & 2.11 & 2.06 & 1.43 & 1.48 \\
\hline
\end{tabular}

$P=$ preliminary data.

Note: Data in this table are revised from the data contained in the previous EIA report, Emissions of Greenhouse Gases in the United States 1987-1992, DOE/EIA-0573 (Washington, DC, November 1994).

Sources: Energy Information Administration, Natural Gas Annual, DOE/EIA-0131 (Washington, DC, 1987-1993), and Natural Gas Monthly, DOE/EIA-0130(95/05) (Washington, DC, May 1995); and U.S. Department of Energy, An Evaluation of the Relationship Between the Production and Use of Energy and Atmospheric Methane Emissions, DOE/NBB-0088P (Washington, DC, April 1990).

multiplying the amount of production or consumption of the compound by a carbon coefficient (the relative amount of carbon in that compound), a process-specific estimate is derived. In 1993, industrial processes accounted for 17.3 million metric tons of carbon emissions (Table 14). Preliminary figures for 1994 indicate an increase to 17.7 million metric tons of carbon.

\section{Cement Manufacture}

As shown in Table 14, more than half of the carbon dioxide emissions from industrial sources originate from cement manufacturing. The following four basic types of materials are required to make cement: calcium, silicon, aluminum, and iron. Substrates of these materials are ground into a powder and heated in a kiln. While in the kiln, limestone (the predominant source of calcium) is broken down into carbon dioxide and lime. The carbon dioxide is driven off into the atmosphere. After the kilning process has been completed, cement clinker is left.

One mole of calcined limestone produces one mole of carbon dioxide and one mole of lime. Since virtually all of the lime produced is absorbed into the clinker, the lime content of clinker is assumed to be representative of the amount of carbon dioxide that is emitted.

In order to estimate emissions from cement manufacture, a carbon coefficient must be calculated. The EIA has adopted the IPCC recommendation that 64.6 percent of cement clinker is lime. ${ }^{27}$ Multiplying this lime content factor by the ratio of carbon produced to lime produced yields the coefficient for cement clinker. A separate coefficient is necessary for estimating emissions from the additional lime used to produce masonry cement. In this case, the amount of lime not accounted for as clinker is assumed to be 3 percent. ${ }^{28}$ This factor is then multiplied by the same production ratio of carbon to lime, generating the carbon coefficient for masonry cement.

Production of cement clinker rose to 69 million metric tons in 1994, resulting in carbon emissions of $9.5 \mathrm{mil}-$ lion metric tons. Emissions from masonry cement production have stabilized at 0.02 million metric tons of carbon annually over recent years.

\section{Limestone and Dolomite Consumption}

Limestone and dolomite are interchangeably used as a basic ingredient in lime manufacturing and as an impurity-removing flux in iron smelting. Additionally, limestone is consumed for glass and steel manufacture and flue gas desulfurization.

As noted above, lime is produced by heating a calciumrich substance such as limestone or dolomite. This process emits carbon dioxide. As shown in Table 14, lime manufacturing is the predominant source of emissions from limestone and dolomite consumption, contributing over 3.6 million metric tons of carbon in 1993. Preliminary figures for 1994 indicate a slight increase to 3.7 million metric tons of carbon. A rising trend has been developing since 1991. Carbon dioxide emissions from the other consumptive uses totaled approximately

\footnotetext{
${ }^{27}$ International Panel on Climate Change, Greenhouse Gas Inventory Reference Manual, IPCC Guidelines for National Greenhouse Gas Inventories, Vol. 3 (Paris, France, 1995), p. 2.4.

${ }^{28}$ U.S. Environmental Protection Agency, Inventory of U.S. Greenhouse Gas Emissions and Sinks: 1990-1993 (Washington, DC, 1994$)$, p. 32.
} 
Table 14. U.S. Carbon Dioxide Emissions from Industrial Sources, 1987-1994

(Million Metric Tons of Carbon)

\begin{tabular}{|c|c|c|c|c|c|c|c|c|}
\hline Source & 1987 & 1988 & 1989 & 1990 & 1991 & 1992 & 1993 & P1994 \\
\hline \multicolumn{9}{|l|}{ Cement Manufacture } \\
\hline Clinker Production & 8.62 & 8.67 & 8.69 & 8.75 & 8.51 & 8.59 & 9.09 & 9.47 \\
\hline Masonry Cement $\ldots \ldots \ldots \ldots$ & 0.02 & 0.02 & 0.02 & 0.02 & 0.02 & 0.02 & 0.02 & 0.02 \\
\hline Total $\ldots \ldots \ldots \ldots \ldots$ & 8.64 & 8.69 & 8.71 & 8.77 & 8.53 & 8.61 & 9.11 & 9.49 \\
\hline \multicolumn{9}{|l|}{ Other Industrial } \\
\hline \multicolumn{9}{|l|}{ Limestone Consumption } \\
\hline Lime Manufacture... & 3.06 & 3.31 & 3.33 & 3.39 & 3.36 & 3.47 & 3.63 & 3.70 \\
\hline Iron Smelting ...... & 0.49 & 0.50 & 0.51 & 0.47 & 0.44 & 0.37 & 0.31 & 0.30 \\
\hline Steelmaking $\ldots \ldots \ldots \ldots$ & 0.10 & 0.10 & 0.13 & 0.08 & 0.09 & 0.07 & 0.13 & 0.13 \\
\hline Glass Manufacture & 0.08 & 0.06 & 0.03 & 0.03 & 0.03 & 0.04 & 0.05 & 0.06 \\
\hline Flue Gas Desulfurization & 0.47 & 0.45 & 0.53 & 0.52 & 0.55 & 0.54 & 0.51 & 0.56 \\
\hline Total $\ldots \ldots \ldots \ldots$ & 4.19 & 4.43 & 4.53 & 4.50 & 4.46 & 4.49 & 4.63 & 4.76 \\
\hline Dolomite Consumption & 0.15 & 0.12 & 0.08 & 0.09 & 0.10 & 0.08 & 0.07 & 0.08 \\
\hline Soda Ash Manufacture . . . . . . & 0.79 & 0.86 & 0.93 & 0.92 & 0.92 & 0.94 & 0.91 & 0.92 \\
\hline \multicolumn{9}{|l|}{ Soda Ash Consumption } \\
\hline Glass Manufacture $\ldots \ldots \ldots$ & 0.38 & 0.38 & 0.37 & 0.36 & 0.34 & 0.35 & 0.35 & 0.36 \\
\hline Flue Gas Desulfurization ..... & 0.02 & 0.02 & 0.03 & 0.02 & 0.02 & 0.02 & 0.02 & 0.02 \\
\hline Sodium Silicate $\ldots \ldots \ldots \ldots$ & 0.06 & 0.05 & 0.05 & 0.05 & 0.05 & 0.05 & 0.06 & 0.06 \\
\hline Sodium Tripolyphosphate .... & 0.04 & 0.04 & 0.04 & 0.04 & 0.03 & 0.03 & 0.03 & 0.03 \\
\hline Total ............... & 0.50 & 0.50 & 0.49 & 0.46 & 0.44 & 0.45 & 0.46 & 0.47 \\
\hline Carbon Dioxide Manufacture ... & 0.21 & 0.22 & 0.23 & 0.24 & 0.25 & 0.26 & 0.26 & 0.27 \\
\hline Aluminum Production .. & 1.69 & 1.99 & 2.03 & 2.04 & 2.08 & 2.04 & 1.86 & 1.67 \\
\hline Total Other Industrial & 7.53 & 8.11 & 8.30 & 8.26 & 8.26 & 8.27 & 8.20 & 8.17 \\
\hline Total $\ldots \ldots \ldots \ldots \ldots$ & 16.17 & 16.80 & 17.00 & 17.03 & 16.79 & 16.88 & 17.31 & 17.66 \\
\hline
\end{tabular}

$P=$ preliminary data.

Notes: Data in this table are revised from the data contained in the previous EIA report, Emissions of Greenhouse Gases in the United States 1987-1992, DOE/EIA-0573 (Washington, DC, November 1994). Totals may not equal sum of components due to independent rounding.

Sources: Methodologies documented in this chapter and numerous sources of trend data. U.S. Department of the Interior, Bureau of Mines, Soda Ash Annual Report (Washington, DC, various years). American Iron and Steel Institute Annual Statistical Report (Washington, DC, various years). U.S. Department of the Interior, Bureau of Mines, Mineral Commodity Summaries (Washington, DC, various years). U.S. Department of the Interior, Bureau of Mines, Cement Annual Report (Washington, DC, various years). U.S. Department of the Interior, Bureau of Mines, Crushed Stone Annual Report (Washington, DC, various years). Chemical Manufacturers Association, U.S. Chemical Industry Statistical Handbook 1993 (Washington, DC, September 1993). Energy Information Administration unpublished survey data, Steam Electric Plant Operation and Design Report, Form ElA-767(Washington, DC, various years). Freedonia Group, Inc., Carbon Dioxide, Business Research Report B286 (Cleveland, OH, November 1991), and Carbon Dioxide, Industry Study 564 (Cleveland, OH, February 1994).

1 million metric tons of carbon in 1993 and have remained relatively stable in recent years.

\section{Soda Ash Manufacture and Consumption}

Two methods are used to manufacture natural soda ash in the United States. The majority of production comes from Wyoming, where soda ash is manufactured by calcination of trona ore in the form of naturally occurring sodium sesquicarbonate. For every mole of soda ash created in this reaction, one mole of carbon dioxide is also produced and vented to the atmosphere. The other process used to manufacture soda ash is carbonation of brines; however, the carbon dioxide driven off in this process is captured and reused. In order to ensure that carbon dioxide from the second process is not included in emissions estimates, the calculations in this report are derived solely from trona ore production figures. Approximately 1.8 metric tons of trona ore are required to yield 1 metric ton of soda ash. In 1994, trona ore production totaled 14.6 million metric tons, resulting in carbon emissions of 0.9 million metric tons.

Once manufactured, most soda ash is consumed in glass and chemical production. Other uses include 
water treatment, flue gas desulfurization, soap and detergent production, and pulp and paper production. As soda ash is processed for these purposes, additional carbon dioxide may be emitted if the carbon is oxidized. Because of the limited availability of specific information about such emissions, only certain uses of soda ash are incorporated into this report. Sodium silicate and sodium tripolyphosphate are included in this category as chemicals manufactured from soda ash and components of detergents. Emissions from soda ash consumption are relatively small and stable, contributing a flux of only 0.46 million metric tons of carbon to the atmosphere in 1993.

\section{Carbon Dioxide Manufacture}

Carbon dioxide is produced from a small number of natural wells and as a byproduct of chemical (i.e., ammonia) manufacturing. The Freedonia Group has determined that the United States exhibits an 80-20 percent split between carbon dioxide produced as a byproduct and carbon dioxide produced from wells. ${ }^{29}$ Emissions of byproduct carbon dioxide are incorporated into the natural gas energy consumption estimates as nonfuel, nonsequestered carbon and, therefore, are not included here (to avoid double-counting).
Most carbon dioxide produced from wells is injected back into the ground for enhanced oil recovery. This process sequesters the carbon dioxide, at least in the short run. Conceptually, only carbon dioxide produced from wells and diverted to industrial use is emitted to the atmosphere. The Freedonia Group estimates nonsequestering industrial use at 1.3 million metric tons of carbon in $1993 .^{30}$ If 20 percent of this industrial use is supplied by wells, emissions can be estimated at 0.26 million metric tons of carbon. Based on the Freedonia report, the 1994 estimate is calculated assuming an annual 4.2-percent increase, implying emissions of 0.29 million metric tons of carbon.

\section{Aluminum Manufacture}

Aluminum metal is produced through an electrolytic reduction process. Aluminum oxide $\left(\mathrm{Al}_{2} \mathrm{O}_{3}\right)$ is exposed to an anode of carbon, forming aluminum (Al) and carbon dioxide. Research indicates that 1.5 to 2.2 metric tons of carbon dioxide are emitted per metric ton of aluminum produced. ${ }^{31}$ The EIA uses the midpoint of this range for estimating emissions. Aluminum production fell to 3.7 million metric tons in 1993, resulting in 1.86 million metric tons of carbon being vented to the atmosphere. Preliminary figures for 1994 show that these emissions have continued to decline.

\footnotetext{
${ }^{29}$ The Freedonia Group, Inc., Carbon Dioxide, Business Research Report B286 (Cleveland, OH, November 1991$)$, p. 46.

${ }^{30}$ The Freedonia Group, Inc., Carbon Dioxide, Industry Study 564 (Cleveland, OH, February 1994), p. 37.

${ }^{31}$ D. Abrahamson, "Aluminum and Global Warming," Nature, Vol. 356 (April 1992), p. 484.
} 


\section{Methane Emissions}

\section{Overview}

Estimated U.S. anthropogenic methane emissions totaled approximately 26.6 million metric tons in 1993, a decrease of more than 1 million metric tons from the levels for each of the previous 3 years (Table 15). Nearly all of this drop can be traced to reduced emissions from energy production and distribution. Emissions from coal mines declined substantially in 1993, as a strike by the United Mine Workers of America (UMWA) reduced underground coal production by more than 50 million short tons. Overall coal production rebounded with the end of the UMWA strike, but production in some of the "gassiest" coal mining regions continued to decline, likely restraining future growth in emissions from this source. Emissions from the oil and gas system also diminished in 1993 as a result of large decreases in the estimated volume of gas vented.
Estimated emissions from landfills declined as well, due to decreases in the volume of waste being landfilled and installation of additional methane recovery systems. However, landfills continued to be the largest source of anthropogenic methane emissions in the United States during 1993, accounting for almost 40 percent of the total. The management of domesticated livestock accounts for a large portion of the remaining U.S. methane emissions, totaling nearly 8.2 million metric tons in 1993, or 31 percent of all methane emissions.

\section{Energy Production and Distribution}

\section{Coal Mining}

Emissions Trends. Methane emissions from coal mining are estimated at 3.5 million metric tons in 1993, down by some 800,000 metric tons from 1992 , and by

Table 15. U.S. Methane Emissions from Anthropogenic Sources, 1987-1994

(Million Metric Tons of Methane)

\begin{tabular}{|c|c|c|c|c|c|c|c|c|}
\hline Source & 1987 & 1988 & 1989 & 1990 & 1991 & 1992 & 1993 & 1994 \\
\hline \multicolumn{9}{|l|}{ Energy Sources } \\
\hline Coal Mining & 4.03 & 4.25 & 4.33 & 4.64 & 4.40 & 4.31 & 3.51 & NA \\
\hline Oil and Gas & 3.25 & 3.34 & 3.34 & 3.37 & 3.44 & 3.48 & 3.18 & 3.26 \\
\hline Stationary Combustion & 0.65 & 0.66 & 0.69 & 0.46 & 0.48 & 0.51 & 0.44 & 0.43 \\
\hline Mobile Sources ..... & 0.30 & 0.29 & 0.28 & 0.27 & 0.25 & 0.25 & 0.24 & NA \\
\hline Total Energy Sources & 8.23 & 8.54 & 8.64 & 8.73 & 8.57 & 8.55 & 7.37 & NA \\
\hline \multicolumn{9}{|l|}{ Area Sources } \\
\hline Landfills ........ & 10.53 & 10.64 & 10.65 & 10.81 & 10.72 & 10.60 & 10.43 & NA \\
\hline \multicolumn{9}{|l|}{ Agricultural Sources } \\
\hline Ruminant Animals. & 5.08 & 5.10 & 5.08 & 5.13 & 5.31 & 5.39 & 5.46 & 5.67 \\
\hline Animal Waste ... & 2.63 & 2.65 & 2.61 & 2.62 & 2.72 & 2.73 & 2.73 & 2.72 \\
\hline Rice Paddies & 0.33 & 0.41 & 0.38 & 0.40 & 0.39 & 0.44 & 0.40 & 0.46 \\
\hline Crop Residue Burning ... & 0.12 & 0.10 & 0.12 & 0.13 & 0.12 & 0.14 & 0.11 & 0.15 \\
\hline Total Agricultural Sources & 8.16 & 8.26 & 8.19 & 8.28 & 8.54 & 8.69 & 8.69 & 9.00 \\
\hline Industrial Processes . .... & 0.11 & 0.12 & 0.12 & 0.12 & 0.11 & 0.12 & 0.12 & 0.12 \\
\hline Total $\ldots \ldots \ldots \ldots \ldots \ldots \ldots$ & 27.03 & 27.56 & 27.60 & 27.95 & 27.94 & 27.96 & 26.62 & NA \\
\hline
\end{tabular}

$\mathrm{NA}=$ not available.

Notes: Data in this table are revised from the data contained in the previous ElA report, Emissions of Greenhouse Gases in the United States 1987-1992, DOE/EIA-0573 (Washington, DC, November 1994). Totals may not equal sum of components due to independent rounding.

Sources: EIA estimates presented in this chapter. Crop residue burning-U.S. Department of Agriculture, National Agricultural Statistics Service, Crop Production annual reports. Emissions calculations based on Intergovernmental Panel on Climate Change, Greenhouse Gas Inventory Reference Manual, IPCC Guidelines for National Greenhouse Gas Inventories, Vol. 3 (Paris, France, 1995), pp. 4.50-4.62. 
more than 1 million metric tons from 1990 (Table 16). This unusually large decrease in emissions was primarily the result of a strike by the UMWA that significantly hampered underground coal production. The UMWA struck against selected operations of the Bituminous Coal Operators Association, including some of the gassiest mines in the United States. Consequently, coal production and, presumably, ventilation and degasification system emissions were down dramatically. It should be noted, however, that temporarily closed mines are likely to continue to emit considerable amounts of methane while production is suspended. Such emissions would not be captured in this report's estimates. An increase in methane recovery for energy also contributed to the sharp decline in emissions during 1993, as four recovery projects came on line in western Virginia during mid-1992. ${ }^{32}$

Emissions from coal mines grew steadily between 1983 and 1990, when underground coal production reached a high of 424 million short tons. At that time, emissions from coal mines represented 17 percent of all anthropogenic methane emissions in the United States and 58 percent of emissions from energy production and distribution. By 1993, these shares had fallen to 13 percent and 52 percent, respectively, largely as the result of a 17-percent decrease in underground coal output.
Estimates of emissions from coal mines have been revised for the period 1987-1992, compared with estimates presented in last year's report. ${ }^{33}$ This is due to a change in the method used for calculating emissions from the ventilation systems of the Nation's gassiest underground mines (see discussion below), the inclusion of measured ventilation data for 1993, and the addition of degasification emissions from four mines that had previously been overlooked. The revised method results in emissions estimates for 1988 through 1992 that are between 100,000 and 200,000 metric tons higher than previously reported.

Methane Formation and Release. The natural processes that create coal also create methane, which is stored in the pore space of solid coalbeds and fills the cracks and fissures within the coal. The volume of methane produced increases with temperature. Because temperature tends to increase with depth, methane content, coal rank, and coalbed depth are correlated.

Other important variables determining methane content in a coalbed include moisture content and porosity. Low porosity coal contains less methane. Methane produced that is not held in the coal pores either migrates to the atmosphere through cracks in the coal seam or is stored in the surrounding strata of the coal

Table 16. U.S. Methane Emissions from Coal Mining and Post-Mining Activities, 1987-1994 (Million Metric Tons of Methane)

\begin{tabular}{|c|c|c|c|c|c|c|c|c|}
\hline Source & 1987 & 1988 & 1989 & 1990 & 1991 & 1992 & 1993 & 1994 \\
\hline \multicolumn{9}{|l|}{ Surface Mining } \\
\hline Mining $\ldots \ldots$ & 0.39 & 0.40 & 0.41 & 0.43 & 0.42 & 0.42 & 0.42 & NA \\
\hline Post-Mining & 0.03 & 0.03 & 0.04 & 0.04 & 0.04 & 0.04 & 0.04 & NA \\
\hline \multicolumn{9}{|l|}{ Underground Mining } \\
\hline Ventilation (Gassy Mines) & 2.03 & 2.04 & 1.98 & 2.13 & 2.05 & 2.12 & 1.82 & NA \\
\hline Ventilation (Nongassy Mines) & 0.02 & 0.02 & 0.03 & 0.03 & 0.03 & 0.02 & 0.03 & NA \\
\hline Degasification . & 1.25 & 1.43 & 1.52 & 1.63 & 1.51 & 1.48 & 1.16 & NA \\
\hline Post-Mining & 0.56 & 0.58 & 0.59 & 0.64 & 0.61 & 0.61 & 0.53 & NA \\
\hline Methane Recovery for Energy (-) & 0.25 & 0.25 & 0.25 & 0.25 & 0.25 & 0.37 & 0.48 & 0.48 \\
\hline Net Emissions $\ldots \ldots \ldots \ldots \ldots \ldots \ldots$ & 4.03 & 4.25 & 4.33 & 4.64 & 4.40 & 4.31 & 3.51 & NA \\
\hline
\end{tabular}

$\mathrm{NA}=$ not available.

Notes: Data in this table are revised from the data contained in the previous ElA report, Emissions of Greenhouse Gases in the United States 1987-1992, DOE/EIA-0573 (Washington, DC, November 1994). Totals may not equal sum of components due to independent rounding.

Sources: Coal production numbers from Energy Information Administration, Coal Production, DOE/EIA-0118 (Washington, DC, various years), and Coal Industry Annual 1993, DOE/EIA-0584(93) (Washington, DC, December 1994). Methane recovery rates from U.S Environmental Protection Agency, Office of Air and Radiation, Anthropogenic Methane Emissions in the United States: Estimates for 1990, Report to Congress (Washington, DC, April 1993), pp. 3-19-3-24; and Identifying Opportunities for Methane Recovery at U.S. Coal Mines: Draft Profiles of Selected Gassy Underground Coal Mines (Washington, DC, September 1994), pp. 6-6-6-8. Ventilation data for 1985, 1988, 1990, and 1993 provided by G. Finfinger, U.S. Department of the Interior, Bureau of Mines, Pittsburgh Research Center.

\footnotetext{
${ }^{32}$ U.S. Environmental Protection Agency, Office of Air and Radiation, Identifying Opportunities for Methane Recovery at U.S. Coal Mines: Draft Profiles of Selected Gassy Underground Coal Mines (Washington, DC, September 1994), pp. 6-6-6-8.

${ }^{33}$ Energy Information Administration, Emissions of Greenhouse Gases in the United States 1987-1992, DOE/EIA-0573 (Washington, DC, November 1994), p. 26.
} 
seam. Methane stored in coal pores or in fissures within the coal seam migrates to areas of lower pressure. Thus, methane is released into the open spaces created by underground coal mines, or into the atmosphere as overlying strata are removed during surface mining.

The volume of methane released during surface mining is small compared with that emitted from underground coal mining. Surface mines are comparatively shallow, and the organic matter converted to coal close to the surface has been subjected to much lower temperatures than organic matter converted to coal deep underground. Further, due to its thin overburden, the methane in coal seams mined from the surface has had a greater opportunity to migrate to the atmosphere prior to mining. All methane remaining in the coal pores after mining is released when the coal is transported and pulverized for combustion.

Estimation Method. There are four major sources of methane emissions from coal mines: ventilation systems in underground coal mines, degasification systems in underground coal mines, emissions from surface mines, and post-mining emissions during transport and pulverization of coal. In addition, closed and abandoned underground coal mines may have measurable emissions in some cases.

Because methane in atmospheric concentrations above 5 percent is explosive and represents a potential fatal hazard to miners, the Mine Safety and Health Administration (MSHA) requires underground mines to be ventilated and sets standards for methane concentrations in the mines. The MSHA conducts quarterly inspections of underground mines, measuring methane concentrations and airflow both at the mine face and at the fan exhausts. Thus, a fairly reliable set of data exist for estimating emissions from the ventilation systems of underground mines. Estimates of emissions from degasification are more uncertain. Degasification emissions are not monitored by any regulatory agency. Where degasification does occur, the method of disposition (e.g., venting, flaring, sale for energy) may not be tabulated. Also, because coalbed methane has recently been recognized as a valuable energy resource in its own right, coalbed methane may be extracted from a coal seam that will not be mined for several years or may never be mined.

Estimates of emissions from surface mines and postmining activity are uncertain. Methane from surface mines does not represent a significant health hazard to miners, cannot be practically recovered for energy, and thus is not directly measured. Similarly, post-mining emissions are not measured. However, because coal is pulverized before combustion, all methane contained in the coal pores that has not desorbed during mining or transport will be released at the combustion site.

Ventilation Systems in Gassy Mines. Emissions from ventilation systems in "gassy" mines accounted for 1.8 million metric tons of emissions, or 52 percent of all methane emitted from coal mining in 1993 (Table 16). ${ }^{34}$ The Department of Interior's Bureau of Mines has collected data from MSHA quarterly mine inspection reports and developed a database for selected years (most recently 1980, 1985, 1988, 1990, and 1993) containing data for the approximately 200 gassiest mines each year.

To estimate emissions from the ventilation systems of underground coal mines, each mine appearing in any year of the Bureau of Mines data was assigned to one of five coal basins: Northern Appalachia, Central Appalachia, Warrior, Illinois, and Western. Using coal production data reported to the Energy Information Administration (EIA) on Form EIA-7A, "Coal Production Report," total annual production from gassy mines in each basin was calculated. An emissions coefficient per ton of coal mined was derived for each basin in the years 1985, 1988, 1990, and 1993 by dividing reported emissions from gassy mines in each basin by total production from those mines. Emissions factors for intervening years were estimated by interpolating between the 1985, 1988, 1990, and 1993 factors.

This method includes two important revisions from that used to develop estimates for last year's emissions report. Measured ventilation data from the Nation's gassiest mines in 1993 were used to develop factors. Also, in developing the emissions factors, the inclusion of coal production data for all mines that have appeared in any year of Bureau of Mines data, rather than only those which appeared in the 1990 compilation, produced a more accurate reflection of total production within gassy mines.

Ventilation Systems in Nongassy Mines. According to the Bureau of Mines, total emissions from nongassy mines (those mines with emissions below 100,000 cubic feet per day) equal less than 2 percent of all emissions from underground mines. ${ }^{35}$ Thus, emissions from "nongassy" mines are of limited consequence, estimated at 30,000 metric tons in 1993 (Table 16).

\footnotetext{
${ }^{34}$ Gassy mines are defined as those underground coal mines with measured emissions from ventilation exhaust in excess of 100,000 cubic feet of methane per day.

${ }^{35}$ M.A. Trevits, G.L. Finfinger, and J.C. LaScola, "Evaluation of U.S. Coal Mine Emissions," in Society for Mining, Metallurgy and Exploration, Proceedings of the Fifth U.S. Mine Ventilation Symposium (Littlejohn Co., 1991).
} 
Using the 1988 Bureau of Mines database, basin level emissions for nongassy mines were estimated by the U.S. Environmental Protection Agency (EPA) at 2 percent of total ventilation system emissions. ${ }^{36}$ Dividing this figure by total production for nongassy mines in 1988 provided a set of basin-level emissions factors for all years. These factors were multiplied by annual production to arrive at the emissions total. The use of a single set of emissions factors for all years may bias the annual estimates, but the minuscule quantity of emissions from nongassy mines makes the bias small.

Mine Degasification. Emissions from degasification systems in underground mines are estimated at just under 1.2 million metric tons in 1993. This represents a decline of 29 percent since 1990 and 22 percent from 1992 (Table 16). Degasification systems are employed in the Nation's gassiest mines, mostly located in Alabama, Virginia, and West Virginia. Degasification systems are used when gas volumes are too high to be practically reduced to safe levels by standard ventilation techniques. When a coalbed contains methane in sufficient quantities and purity for commercial sale, a degasification system may be used to recover gas for sale to pipeline companies.

There are approximately 30 degasification systems currently operating in the United States, with 10 mines recovering gas for pipeline sales. ${ }^{37}$ Estimates of degasification system emissions are based on estimates developed by the EPA for mines believed to have had such systems in place in $1988 .{ }^{38}$ Emissions factors were derived for each coal basin by scaling emissions to production for the mines identified in that survey. The emissions factors were then multiplied by annual production from those mines that are now believed to be operating degasification systems.

Surface Mines. Global average emissions factors recommended by the Intergovernmental Panel on Climate Change (IPCC) were used to estimate emissions from this source. The IPCC provides a range of emissions from 0.3 to 2.0 cubic meters of methane per metric ton of coal mined, developed from studies conducted in the United States, England, France, and Canada. ${ }^{39}$ This report adopts the central estimate produced using these factors. For 1993, emissions from surface mines are estimated at 420,000 metric tons. Emissions from this source have remained nearly stable over the past decade (Table 16).

Emissions from U.S. surface mines have not been systematically measured and are believed to be highly heterogeneous. However, emissions from five surface mines have been evaluated by Piccot et al., ${ }^{40}$ using Fourier Transform Infrared (FTIR) spectroscopy. ${ }^{41}$ Although the sample remains too small to validate or generalize the results, the mines examined revealed emissions rates rivaling some of the gassiest underground mines in the United States. Extrapolating from these mines, Piccot et al. estimated emissions from surface mines at 388,000 metric tons during 1991, a difference of less than 10 percent from the estimate developed for this report.

Post-Mining Emissions. Post-mining emissions, like those from surface mining, are not measured systematically. Once again, this report relies on global average factors recommended by the IPCC. ${ }^{42} \mathrm{Coal}$ mined from the surface has a very small in-situ methane content due to the low temperatures under which it was formed and the low pressures at limited depth. The resulting emissions range -0.0 to 0.2 cubic meters of methane per metric ton of coal mined-produces a nearly insignificant midpoint estimate of 40,000 metric tons emitted in 1993 (Table 16).

Emissions from transport and pulverization of underground coal are more substantial. Using the IPCC emissions range of 0.9 to 4.0 cubic meters per metric ton of coal mined, emissions from this source are estimated at just over 500,000 metric tons for 1993 (Table 16).

\footnotetext{
${ }^{36}$ U.S. Environmental Protection Agency, Office of Air and Radiation, Anthropogenic Methane Emissions in the United States: Estimates for 1990 (Washington, DC, April 1993), pp. 3-19-3-24.

${ }^{37}$ U.S. Environmental Protection Agency, Office of Air and Radiation, Identifying Opportunities for Methane Recovery at U.S. Coal Mines: Draft Profiles of Selected Gassy Underground Coal Mines (Washington, DC, September 1994).

${ }^{38}$ U.S. Environmental Protection Agency, Office of Air and Radiation, Anthropogenic Methane Emissions in the United States: Estimates for 1990 (Washington, DC, April 1993), pp. 3-19-3-24.

${ }^{39}$ Intergovernmental Panel on Climate Change, Greenhouse Gas Inventory Reference Manual, IPCC Guidelines for National Greenhouse Gas Inventories, Vol. 3 (Paris, France, 1994), pp. 1.98-1.131.

${ }^{40}$ S.D. Piccot, S.S. Masemore, E. Ringler, and D.A. Kirchgessner, "Developing Improved Methane Emission Estimates for Coal Mining Operations," Presented at the 1995 Greenhouse Gas Emissions and Mitigation Research Symposium (U.S. Environmental Protection Agency, June 27-29, 1995).

${ }^{41}$ An open-path FTIR spectrometer emits an infrared beam across a path of several hundred meters. The beam is reflected back with mirrors toward a remote sensing device that determines the amount of infrared light absorbed by various compounds, including methane. Thus, the volume of methane present in the path of the infrared beam can be estimated.

${ }^{42}$ Intergovernmental Panel on Climate Change, Greenhouse Gas Inventory Reference Manual, IPCC Guidelines for National Greenhouse Gas Inventories, Vol. 3 (Paris, France, 1994), pp. 1.98-1.131.
} 
Inactive and Abandoned Mines. The treatment of closed mines varies, depending on local regulations and whether the mine is expected to be temporarily or permanently inactive. Mines may be completely sealed by backfilling or left open to the atmosphere with cement caps and vent pipes. According to the MSHA, some 6,000 underground coal mines in the United States have been abandoned since the early 1970s. Only a fraction of those are vented, and those that lie below the water table are likely to flood and have limited emissions. However, those that are vented and do not flood may have substantial emissions, and measurements at several abandoned mines have shown emissions rates comparable to those for some of the gassiest active mines in the United States. ${ }^{43}$

Extrapolating from measurements at 20 abandoned underground coal mines, Piccot et al. estimated emissions from this source at approximately 280,000 metric tons. Because the limited data make extrapolation highly uncertain, these estimates are not included in this report. Emissions from those abandoned mines measured in 1993 totaled 25,000 metric tons. Some estimate of emissions from this source probably will be included in future years' reports.

Methane Recovery for Energy. From 1987 to 1991, about 250,000 metric tons of methane were recovered and sold to pipeline companies annually from mines in Alabama and Utah. In May 1992, four mines in western Virginia began recovering and selling gas. By the end of 1993, methane recovered from all mines totaled nearly 500,000 metric tons annually. ${ }^{44}$

\section{Oil and Gas Production, Processing, and Distribution}

Emissions Trends. In 1993, estimated methane emissions from the U.S. oil and gas system totaled 3.2 million metric tons, a 9-percent decline from 1992 levels. This decline resulted largely from a decrease of 250,000 metric tons in estimated emissions from associated gas vented from oil wells (Table 17). Emissions from the oil and gas system represented 12 percent of all U.S. methane emissions in 1993 and 48 percent of emissions from energy production and distribution.

Table 17. U.S. Methane Emissions from Oil and Gas Operations, 1987-1994 (Million Metric Tons of Methane)

\begin{tabular}{|c|c|c|c|c|c|c|c|c|}
\hline Source & 1987 & 1988 & 1989 & 1990 & 1991 & 1992 & 1993 & P1994 \\
\hline \multicolumn{9}{|l|}{ Oil and Gas Production } \\
\hline Natural Gas Wellheads & 0.22 & 0.22 & 0.23 & 0.23 & 0.24 & 0.24 & 0.25 & 0.25 \\
\hline Oil Wells & 0.04 & 0.05 & 0.04 & 0.04 & 0.04 & 0.04 & 0.04 & 0.04 \\
\hline Gathering Pipelines . . . . & 0.34 & 0.33 & 0.33 & 0.32 & 0.31 & 0.31 & 0.28 & 0.28 \\
\hline Gas Processing Plants & 0.08 & 0.08 & 0.08 & 0.09 & 0.10 & 0.10 & 0.10 & 0.10 \\
\hline Heaters, Separators, Dehydrators & 0.44 & 0.46 & 0.46 & 0.47 & 0.48 & 0.48 & 0.50 & 0.52 \\
\hline Total $\ldots \ldots \ldots \ldots \ldots \ldots \ldots$ & 1.12 & 1.14 & 1.14 & 1.16 & 1.17 & 1.18 & 1.16 & 1.19 \\
\hline Gas Venting $\ldots \ldots \ldots \ldots$ & 0.73 & 0.77 & 0.77 & 0.75 & 0.81 & 0.83 & 0.58 & 0.60 \\
\hline Gas Transmission and Distribution ... & 1.33 & 1.34 & 1.35 & 1.37 & 1.38 & 1.39 & 1.36 & 1.39 \\
\hline Oil Refining and Transportation & 0.08 & 0.08 & 0.08 & 0.08 & 0.08 & 0.08 & 0.08 & 0.09 \\
\hline Total $\ldots \ldots \ldots \ldots \ldots \ldots \ldots \ldots$ & 3.25 & 3.34 & 3.34 & 3.37 & 3.44 & 3.48 & 3.18 & 3.26 \\
\hline
\end{tabular}

$P=$ preliminary data.

Notes: Data in this table are revised from the data contained in the previous EIA report, Emissions of Greenhouse Gases in the United States 1987-1992, DOE/EIA-0573 (Washington, DC, November 1994). Totals may not equal sum of components due to independent rounding.

Sources: U.S. Environmental Protection Agency, Anthropogenic Methane Emissions in the United States: Estimates for 1990(April 1993); World Oil (February issue, various years); American Gas Association, Gas Facts (various years); Energy Information Administration, Natural Gas Annual, DOE/ElA-0131 (various years); Radian Corporation, Global Emissions of Methane from Petroleum Sources (February 1992); Energy Information Administration, Annual Energy Review 1994, DOE/EIA-0384(94) (Washington, DC, July 1995); Energy Information Administration, Petroleum Supply Annual, DOE/EIA-0340 (Washington, DC, various years).

\footnotetext{
${ }^{43}$ S.D. Piccot, S.S. Masemore, E. Ringler, and D.A. Kirchgessner, "Developing Improved Methane Emission Estimates for Coal Mining Operations," Presented at the 1995 Greenhouse Gas Emissions and Mitigation Research Symposium (U.S. Environmental Protection Agency, June 27-29, 1995).

${ }^{44}$ U.S. Environmental Protection Agency, Office of Air and Radiation, Identifying Opportunities for Methane Recovery at U.S. Coal Mines: Draft Profiles of Selected Gassy Underground Coal Mines (Washington, DC, September 1994), pp. 6-6-6-8.
} 


\section{Ongoing Research}

The U.S. Environmental Protection Agency, the Gas Research Institute, the American Petroleum Institute, and the American Gas Association are currently cooperating on a study to characterize more accurately methane emissions from the domestic natural gas industry. The study focuses on producing a more complete accounting of emissions sources and using improved measurement techniques for developing emissions factors. Preliminary results indicate that 1992 emissions from the natural gas system may be much larger than the estimates that appear in this report.* As the research is completed, the EIA will review the data obtained and incorporate any new information into future reports.

\footnotetext{
*D. Kirchgessner, R.M. Cowgill, M. Harrison, and L.M. Campbell, "Methods for Estimating Methane Emissions from the Domestic Natural Gas Industry," Presented at the 1995 Greenhouse Gas Emissions and Mitigation Research Symposium (U.S. Environmental Protection Agency, National Risk Management Research Laboratory, Air Pollution Prevention Division, June 1995).
}

several points, including oil wells, oil refineries, natural gas wellheads, gas processing plants, and gas transmission and distribution pipelines. The release of natural gas leads to substantial methane emissions.

Estimation Methods. The U.S. oil and gas system is large (23 trillion cubic feet of withdrawals and 1.7 million miles of pipeline) and structurally diverse. It would be impossible to measure all intentional and fugitive emissions of methane. Instead, a series of emissions factors for system components must be used and scaled to readily available data, such as pipeline mileage and throughput. With the exception of gas vented, this report relies on emissions factors derived from a small sample of system components.

Oil and Gas Production and Processing. In 1993, a highest ever 283,812 natural gas wells produced 16.93 trillion cubic feet of gas. This was approximately 73 percent of total gas production, with the remaining 6 trillion cubic feet captured as associated gas withdrawn from oil wells.

Natural gas extracted at the wellhead is transferred to processing plants through gathering pipelines. As the gas is transferred, leakage from valves, meters, and flanges occurs. Some pneumatic valves use pressurized natural gas as motive power and release gas when reset. Additional emissions occur when pipelines are emptied during maintenance operations. At the gas processing plant, heavy hydrocarbons that are particularly valuable are removed, as are contaminants such as hydrogen sulfide that may damage pipelines and other equipment. At the processing plant, leakage, maintenance operations, and system upsets also result in emissions. System upsets result from sudden increases in pressure that require the release of gas as a safety measure or, failing that, result in a system rupture. Such events are uncommon in the U.S. oil and gas system and contribute only slightly to overall emissions.

The EPA has published emissions factors for the oil and gas system developed from model oil and gas production facilities, transmission lines, and processing plants. ${ }^{48}$ Emissions factors for oil and gas wells are based on studies of four model facilities. Factors for gathering pipelines are based on two model transmission line systems (discussed below), and factors for gas processing facilities are based on analyses of three model plants. These factors were modified slightly for

\footnotetext{
${ }^{45}$ Energy Information Administration, Emissions of Greenhouse Gases in the United States 1987-1992, DOE/EIA-0573 (Washington, DC, November 1994), p. 28.

${ }^{46}$ B. Nagy and U. Columbo (eds.), Fundamental Aspects of Petroleum Chemistry (New York, NY: Elsevier Publishing, 1967), pp. 1-5.

${ }^{47}$ J.M. Hunt, Petroleum Geochemistry and Geology (San Francisco, CA: W.H. Freeman, 1979), pp. 150-152.

${ }^{48}$ U.S. Environmental Protection Agency, Office of Air and Radiation, Anthropogenic Methane Emissions in the United States: Estimates for 1990 (Washington, DC, April 1993), pp. 2-22.
} 
scaling purposes. Estimates of emissions from oil and gas wells are based on the number of wells in operation, emissions from gathering pipelines are based on pipeline miles, and emissions from gas processing plants are scaled to gas throughput. For 1993, total methane emissions from oil and gas wells, gathering pipelines, and gas processing were estimated at 1.2 million metric tons, down slightly from 1992 emissions and virtually identical to 1990 emissions (Table 17).

Gas Venting. Often, when a reservoir is developed for oil extraction, associated natural gas is produced at the wellhead. In the United States, because of its welldeveloped natural gas market and infrastructure, associated gas is usually captured and sold commercially. In 1993, 6 trillion cubic feet of associated natural gas were withdrawn from oil wells. ${ }^{49}$ On occasion, however, the flow of associated gas may be too small or intermittent to be of value or have an insufficient heating value to be marketed, or the site may lack the necessary gas gathering and processing facilities. In such cases the gas is vented or flared.

When associated gas is flared, its methane content is converted to carbon dioxide (see emissions estimates in Chapter 2). When vented, methane is released directly into the atmosphere. Each State reports an annual volume of vented and flared gas to the EIA. However, no distribution between venting and flaring is provided.

To estimate emissions from venting, the volume of gas reported as vented and flared by each State is allocated according to a venting share estimate developed for each State in a 1990 Department of Energy study. ${ }^{50} \mathrm{~A}$ national quantity for vented gas is calculated by aggregating the individual State figures. This method improves on that used for previous EIA emissions reports, which applied a national average venting share to all State data. As a consequence, the level of emissions estimates from this source are, on average, 37 percent higher for 1987-1992 using the new method. Some of the largest State sources were underrepresented when a simple national average was used.

On an annual basis, emissions reductions from venting were achieved in 1993. The volume of gas vented was estimated as 30 billion cubic feet, a 30 -percent reduction from 1992. The reduction reflects commissioning of gas gathering facilities in areas where gas formerly was lost. As a result, estimated methane emissions from this source declined from 830,000 to 580,000 metric tons (Table 17).

Gas Transmission and Distribution. High-pressure transmission pipelines are used to transport natural gas from production fields and gas processing facilities to distribution pipelines. The gas is sent through gate stations where its pressure is lowered for distribution to end users. Again, leakage from the pipelines, valves, and other equipment is the primary source of emissions. Compressor exhaust, pneumatic devices, and routine maintenance are also sources of methane emissions.

The emissions factors used to calculate emissions from transmission pipelines, gate stations, and distribution pipelines were developed by the EPA. They are the result of studies of 4 transmission systems, 28 gate stations, and 2 companies' distribution networks. ${ }^{51}$

The emissions factors for pipelines have been scaled to mileage. However, with low-emission plastic pipeline being the preferred material for replacement and expansion of distribution systems, emissions may actually increase at a lesser rate than mileage, as older leaky pipe is eliminated. The transmission and distribution of natural gas contributed an estimated 1.4 million metric tons of methane emissions in 1993 (Table 18). This represents a 2-percent decline from 1992 levels, largely due to a reduction in miles of transmission pipeline.

Oil Refining and Transportation. Methane emissions from refining operations can be attributed to three sources: fugitive emissions, tank farms, and flaring. Fugitive emissions are the result of equipment leakage during the portion of the refining process where methane is separated from the oil. Emissions at tank farms are produced by vapor displacement when oil is transferred to storage tanks upon arrival at the refinery. Additionally, any methane not destroyed by flaring operations is emitted to the atmosphere.

Transportation-related emissions also result from vapor displacement. In this case, however, the emissions occur during loading and unloading of oil to barges and ships. Emissions from pipelines, trucks, and rail cars are exceedingly minor and are not included in this report.

Emissions from oil refining and transportation were estimated using factors provided in a 1992 Radian Corporation report. ${ }^{52}$ The emissions factor used in the

\footnotetext{
${ }^{49}$ Energy Information Administration, Natural Gas Annual 1993, DOE/EIA-0131(93) (Washington, DC, November 1994 ), p. 6.

${ }^{50}$ U.S. Department of Energy, An Evaluation of the Relationship Between the Production and Use of Energy and Atmospheric Methane Emissions, DOE/NBB-0088P (Washington, DC, April 1990). See Appendix C.

${ }^{51}$ U.S. Environmental Protection Agency, Office of Air and Radiation, Anthropogenic Methane Emissions in the United States: Estimates for 1990 (Washington, DC, April 1993), pp. 2-22.

${ }^{52}$ Radian Corporation, Global Emissions of Methane from Petroleum Sources, prepared for the American Petroleum Institute (Research Triangle Park, NC, February 17, 1992).
} 
Table 18. U.S. Methane Emissions from Natural Gas Transmission and Distribution, 1987-1994

(Million Metric Tons of Methane)

\begin{tabular}{|c|c|c|c|c|c|c|c|c|}
\hline Source & 1987 & 1988 & 1989 & 1990 & 1991 & 1992 & 1993 & P1994 \\
\hline $\begin{array}{l}\text { Transmission Pipelines } \ldots \ldots \ldots \ldots \\
\text { Distribution Systems }\end{array}$ & 1.02 & 1.02 & 1.03 & 1.04 & 1.05 & 1.06 & 1.01 & 1.03 \\
\hline Plastic Distribution Pipelines & 0.01 & 0.01 & 0.01 & 0.01 & 0.01 & 0.01 & 0.01 & 0.01 \\
\hline Nonplastic Distribution Pipelines & 0.16 & 0.16 & 0.16 & 0.16 & 0.16 & 0.16 & 0.16 & 0.17 \\
\hline Gate Stations & 0.11 & 0.11 & 0.12 & 0.12 & 0.12 & 0.13 & 0.13 & 0.14 \\
\hline Distribution System Upsets & 0.04 & 0.04 & 0.04 & 0.04 & 0.04 & 0.04 & 0.04 & 0.05 \\
\hline Distribution Systems Total & 0.31 & 0.32 & 0.32 & 0.33 & 0.33 & 0.34 & 0.35 & 0.36 \\
\hline Total $\ldots \ldots \ldots \ldots \ldots \ldots \ldots \ldots$ & 1.33 & 1.34 & 1.35 & 1.37 & 1.38 & 1.39 & 1.36 & 1.39 \\
\hline
\end{tabular}

$\mathrm{P}=$ preliminary data.

Note: Totals may not equal sum of components due to independent rounding.

Sources: Emissions factors derived from U.S. Environmental Protection Agency, Anthropogenic Methane Emissions in the United States: Estimates for 1990 (Washington, DC, April 1993). Pipeline mileage from American Gas Association, Gas Facts (various years).

calculations assumes a methane content of 15 percent for the volatile organic compound vapor associated with oil. ${ }^{53}$ Estimated emissions from oil refining and transportation have remained relatively stable for a decade, adding 86,000 metric tons of methane to the atmosphere in 1993 (Table 19).

\section{Energy Consumption}

If fuel combustion were complete, the only products emitted would be carbon dioxide and water. In fact, combustion is rarely complete, and the burning of fossil or renewable fuels emits other radiatively important gases, such as methane, nitrous oxide, carbon monoxide, nitrogen oxides, and nonmethane volatile organic compounds. Methane emissions from stationary and mobile combustion together account for less than 3 percent of all U.S. methane emissions, with wood burning in residential wood stoves representing 55 percent of that total (Table 20).

\section{Stationary Combustion}

Emissions Trends. Methane emissions from stationary source combustion are estimated at 440,000 metric tons in 1993, down 20,000 metric tons from 1990 and some 60,000 metric tons from 1992 (Table 20). The over- whelming majority (more than 85 percent) of stationary source methane emissions are the result of wood burning in residential woodstoves and fireplaces. Use of firewood appears to be declining since 1991, explaining the decrease in overall emissions from this source.

Methane Formation and Release. When carbon-based fuels are combusted, much of the carbon is released as carbon dioxide. However, when combustion is incomplete, methane may also be released. The volume of methane released is a function of the efficiency and temperature of the combustion process. Because most stationary sources are large, highly efficient boilers, methane emissions from these sources are limited.

Estimation Methods. The fuel consumed and the method of combustion for stationary sources of methane vary by economic sector. For example, wood consumed in the industrial sector is combusted in boilers with much higher temperatures and efficiency than the wood combusted in stoves in the residential sector. Thus, specific emissions coefficients are identified by fuel and combustion method. These coefficients were obtained from the EPA's Compilation of Air Pollutant Emission Factors and from the IPCC. ${ }^{54}$ Emissions coefficients were then combined with consumption data in EIA's State Energy Data Report 1993 and Annual Energy Review $1994^{55}$ to yield overall emissions estimates.

\footnotetext{
${ }^{53}$ U.S. Environmental Protection Agency, Office of Air and Radiation, Compilation of Air Emission Factors, AP-42 (Research Triangle Park, NC, September 1991).

${ }^{54}$ U.S. Environmental Protection Agency, Office of Air and Radiation, Office of Air Quality Planning and Standards, Compilation of Air Pollutant Emission Factors, AP-42, Supplement D (Research Triangle Park, NC, September 1991); and Intergovernmental Panel on Climate Change, Greenhouse Gas Inventory Reference Manual, IPCC Guidelines for National Greenhouse Gas Inventories, Vol. 3 (Paris, France, 1994).

${ }^{55}$ Energy Information Administration, State Energy Data Report 1993: Consumption Estimates, DOE/EIA-0214(93) (Washington, DC, May 1994), and Annual Energy Review 1994, DOE/EIA-0384(94) (Washington, DC, July 1995).
} 
Table 19. U.S. Methane Emissions from Oil Refining and Transportation, 1987-1994

(Thousand Metric Tons of Methane)

\begin{tabular}{|c|c|c|c|c|c|c|c|c|}
\hline Source & 1987 & 1988 & 1989 & 1990 & 1991 & 1992 & 1993 & 1994 \\
\hline \multicolumn{9}{|l|}{ Oil Refineries } \\
\hline Fugitive Emissions & 70 & 72 & 73 & 73 & 72 & 73 & 74 & 75 \\
\hline Tank Farms $\ldots \ldots \ldots \ldots$ & 2 & 2 & 2 & 2 & 2 & 2 & 2 & 2 \\
\hline Flaring $\ldots \ldots \ldots \ldots \ldots$ & 2 & 2 & 2 & 2 & 2 & 2 & 2 & 2 \\
\hline $\begin{array}{l}\text { Total } \ldots . . . \ldots \ldots \ldots \ldots \\
\text { Crude Oil Transportation }\end{array}$ & 73 & 75 & 76 & 76 & 76 & 76 & 77 & 79 \\
\hline Marine Vessels ........ & 6 & 6 & 7 & 7 & 6 & 7 & 7 & 7 \\
\hline Total $\ldots \ldots \ldots \ldots \ldots$ & 79 & 82 & 83 & 83 & 82 & 83 & 85 & 86 \\
\hline
\end{tabular}

Sources: Radian Corporation, Global Emissions of Methane from Petroleum Sources (Research Triangle Park, NC, February 1992); Energy Information Administration, Annual Energy Review 1994, DOE/EIA-0384(94) (Washington, DC, July 1995); Energy Information Administration, Petroleum Supply Annual, DOE/EIA-0340 (Washington, DC, various years).

\section{Mobile Combustion}

Emissions Trends. Methane emissions from the transportation sector have been declining steadily for the past decade, despite increases in vehicle miles traveled (VMT). Newer model year automobiles are more fuel efficient and are equipped with more effective emissions control technologies. As the fleet is gradually replaced, the share of VMT accounted for by these lower polluting cars increases. Estimated 1993 methane emissions from mobile combustion were 240,000 metric tons, down from 266,000 metric tons in 1990 (Table 21).

Methane Formation and Release. In automobiles, when the amount of oxygen available is insufficient for complete combustion, methane emissions result. This condition occurs especially in low speed and engine idle situations. Other factors influencing the level of methane emissions include the level of unburnt hydrocarbons passing through the engine, engine maintenance, and post-combustion controls of hydrocarbon emissions, such as catalytic converters.

An increasing share of emissions is generated by lightduty trucks, as consumer tastes shift toward those vehicles. Methane emissions from nonhighway mobile sources account for less than 10 percent of all emissions from transportation. There is some indication that jet planes may draw ambient methane into their engines, combusting it along with fuel and hence reducing net emissions. ${ }^{56}$
Estimation Methods. Mobile sources can be divided into two broad categories: highway sources and nonhighway sources.

Highway Sources. In the United States, highway sources include automobiles, light-duty trucks, motorcycles, buses, and heavy-duty trucks. Emissions factors for these vehicles developed by the IPCC were adopted for this report. ${ }^{57}$ Expressed in terms of grams of methane per kilometer traveled, they vary by vehicle type, fuel used, and emissions control technology employed. Due to the effects of evolving environmental regulations and technological development, the model year of U.S. vehicles is an accurate indicator of emissions control technology employed. Thus, emissions estimates require data on miles traveled by vehicle type and model year.

Miles traveled in personal transportation vehicles (cars and light-duty trucks) are obtained as part of ELA's Residential Transportation Energy Consumption Survey (RTECS). ${ }^{58}$ This survey was conducted in 1983,1985 , 1988, and 1991. Emissions for nonsurvey years were estimated by interpolating between the weighted average estimates for survey years. Emissions estimates for 1992 and 1993 rely on fleet age data reported by the American Automobile Manufacturers Association. ${ }^{59}$ VMT data for nonhousehold vehicles (fleets, rental cars, etc.), motorcycles, buses, and heavy-duty trucks were obtained from the U.S. Department of Transportation, Federal Highway Administration ${ }^{60}$ and reconciled with RTECS data.

\footnotetext{
${ }^{56}$ C.W. Spicer, M.W. Holdren, D.L. Smith, D.P. Hughes, and M.D. Smith, "Chemical Composition of Exhaust From Aircraft Turbine Engines," Journal of Engineering for Gas Turbines and Power, Vol. 114 (January 1992), pp. 111-117.

${ }^{57}$ Intergovernmental Panel on Climate Change, Greenhouse Gas Inventory Reference Manual, IPCC Guidelines for National Greenhouse Gas Inventories, Vol. 3 (Paris, France, 1994), pp. 1.64-1.68.

${ }^{58}$ Energy Information Administration, Household Vehicles Energy Consumption 1991, DOE/EIA-0464(91) (Washington, DC, December 1993, and previous years).

${ }^{59}$ American Automobile Manufacturers Association, AAMA Vehicle Facts and Figures (Detroit, MI, 1994$)$, p. 39.

${ }^{60}$ U.S. Department of Transportation, Federal Highway Administration, Highway Statistics 1993 (Washington, DC, 1995).
} 
Table 20. U.S. Methane Emissions from Stationary Combustion Sources, 1987-1994 (Thousand Metric Tons of Methane)

\begin{tabular}{|c|c|c|c|c|c|c|c|c|}
\hline Source & 1987 & 1988 & 1989 & 1990 & 1991 & 1992 & 1993 & 1994 \\
\hline \multicolumn{9}{|l|}{ Residential } \\
\hline Coal. & * & * & $*$ & * & * & * & $*$ & * \\
\hline Distillate Fuel & 5 & 6 & 5 & 4 & 4 & 5 & 5 & 5 \\
\hline Natural Gas & 5 & 5 & 5 & 5 & 5 & 5 & 5 & 5 \\
\hline LPG . . . . & * & * & * & * & * & * & * & 1 \\
\hline Wood ... & 584 & 600 & 629 & 398 & 420 & 442 & 376 & 368 \\
\hline Total $\ldots \ldots \ldots \ldots$ & 595 & 611 & 640 & 408 & 430 & 452 & 386 & 379 \\
\hline \multicolumn{9}{|l|}{ Commercial } \\
\hline Coal ........ & 1 & 1 & 1 & 1 & 1 & 1 & 1 & 1 \\
\hline Fuel Oil & 1 & 1 & 1 & 1 & 1 & 1 & 1 & 1 \\
\hline Natural Gas . . . . . . . . . & 3 & 3 & 4 & 3 & 4 & 4 & 4 & 4 \\
\hline LPG . . . . . $\ldots \ldots$ & * & * & $*$ & * & * & * & $*$ & * \\
\hline Wood ............... & * & * & * & * & * & * & * & * \\
\hline Total $\ldots \ldots \ldots \ldots \ldots$ & 5 & 6 & 5 & 5 & 5 & 5 & 6 & 6 \\
\hline \multicolumn{9}{|l|}{ Industrial } \\
\hline Coal $\ldots \ldots \ldots \ldots \ldots$ & 7 & 7 & 7 & 7 & 7 & 6 & 6 & 6 \\
\hline Fuel Oil . . . . . . . . . & 2 & 2 & 1 & 1 & 1 & 1 & 2 & 1 \\
\hline Natural Gas & 11 & 11 & 12 & 13 & 13 & 13 & 14 & 14 \\
\hline LPG. & 2 & 3 & 2 & 2 & 3 & 3 & 3 & 3 \\
\hline Wood. & 12 & $a_{13}$ & 12 & 12 & 12 & 13 & 13 & 13 \\
\hline Total ............ & 35 & 36 & 35 & 36 & 35 & 36 & 37 & 38 \\
\hline \multicolumn{9}{|l|}{ Electric Utility } \\
\hline Coal ..... & 10 & 10 & 10 & 10 & 10 & 10 & 11 & 11 \\
\hline Fuel Oil & 1 & 1 & 1 & 1 & 1 & 1 & 1 & 1 \\
\hline Natural Gas & * & * & * & * & * & * & * & * \\
\hline Wood..... & * & * & * & * & * & * & * & * \\
\hline Total $\ldots \ldots \ldots \ldots$ & 11 & 12 & 12 & 11 & 11 & 11 & 12 & 12 \\
\hline \multicolumn{9}{|l|}{ Total All Fuels } \\
\hline Coal ........ & 17 & 18 & 18 & 18 & 18 & 18 & 18 & 18 \\
\hline Fuel Oil $\ldots .$. & 9 & 9 & 9 & 7 & 7 & 7 & 8 & 8 \\
\hline Natural Gas ......... & 19 & 20 & 21 & 21 & 22 & 22 & 23 & 23 \\
\hline LPG $\ldots \ldots \ldots \ldots$ & 3 & 3 & 3 & 3 & 3 & 3 & 3 & 3 \\
\hline Wood. & 597 & 613 & 642 & 411 & 433 & 455 & 389 & 382 \\
\hline Total $\ldots \ldots \ldots \ldots$ & 645 & 664 & 693 & 460 & 482 & 505 & 441 & 434 \\
\hline
\end{tabular}

"Less than 500 metric tons of methane.

${ }^{2}$ Estimate. Underlying energy data not available.

Notes: Data in this table are revised from the data contained in the previous ElA report, Emissions of Greenhouse Gases in the United States 1987-1992, DOE/EIA-0573 (Washington, DC, November 1994). Totals may not equal sum of components due to independent rounding.

Sources: U.S. Environmental Protection Agency, Office of Air and Radiation, Office of Air Quality Planning and Standards, Compilation of Air Pollutant Emission Factors, AP-42 Supplement D (Research Triangle Park, NC, September 1991). Energy Information Administration, State Energy Data Report 1993, DOE/EIA-0214(93) (Washington, DC, July 1995); Monthly Energy Review, DOE/EIA-0035(95/07) (Washington, DC, July 1995); Annual Energy Review 1994, DOE/EIA-0384(94) (Washington, DC, July 1995), p. 267; and Estimates of U.S. Biomass Energy Consumption 1992, DOE/ElA-0548(92) (Washington, DC, May 1994).

Nonhighway Sources. Nonhighway sources include farm equipment, construction equipment, air transport vehicles, ships, and locomotives. The IPCC provides emissions coefficients for these sources in terms of grams of methane per kilogram of fuel consumed. ${ }^{61}$ The factors for ships, farm equipment, locomotives, and construction equipment were multiplied by data contained in EIA's Fuel Oil and Kerosene Sales report. ${ }^{62}$

\footnotetext{
${ }^{61}$ Intergovernmental Panel on Climate Change, Greenhouse Gas Inventory Reference Manual, IPCC Guidelines for National Greenhouse Gas Inventories, Vol. 3 (Paris, France, 1994), pp. 1.64-1.68.

${ }^{62}$ Energy Information Administration, Fuel Oil and Kerosene Sales 1993, DOE/EIA-0535(93) (Washington, DC, October 1994).
} 
Table 21. U.S. Methane Emissions from Mobile Sources, 1987-1994 (Thousand Metric Tons of Methane)

\begin{tabular}{|c|c|c|c|c|c|c|c|c|}
\hline Item & 1987 & 1988 & 1989 & 1990 & 1991 & 1992 & 1993 & 1994 \\
\hline \multicolumn{9}{|l|}{ Motor Vehicles } \\
\hline Passenger Cars & 185 & 173 & 165 & 155 & 14.2 & 141 & 135 & NA \\
\hline Buses $\ldots \ldots \ldots \ldots \ldots$ & 1 & 1 & 1 & 1 & 1 & 1 & 1 & 1 \\
\hline Motorcycles & 5 & 5 & 5 & 5 & 5 & 4 & 4 & 4 \\
\hline Light-Duty Trucks . . . . . . & 68 & 68 & 67 & 65 & 62 & 61 & 61 & NA \\
\hline Other Trucks ..... & 19 & 19 & 20 & 19 & 18 & 18 & 18 & NA \\
\hline Total $\ldots \ldots \ldots \ldots$ & 278 & 266 & 258 & 244 & 228 & 225 & 219 & NA \\
\hline Other Transport & 21 & 22 & 21 & 22 & 21 & 22 & 21 & NA \\
\hline Total Transport . . . . . . . & 299 & 288 & 279 & $266^{\circ}$ & 249 & 246 & 240 & NA \\
\hline
\end{tabular}

$\mathrm{NA}=$ not available.

Sources: Calculations based on vehicle miles traveled from U.S. Department of Transportation, Federal Highway Statistics, various years, Table VM-1. Vehicle emissions coefficients from Intergovernmental Panel on Climate Change, Greenhouse Gas Inventory Reference Manual, IPCC Guidelines for National Greenhouse Gas Inventories, Vol. 3 (Paris, France, 1995), pp. 1.72-1.82. Distribution of passenger car and light duty truck fleet model years for 1983, 1985, 1988, and 1991 according to data in the Energy Information Administration's "Residential Transportation Energy Consumption Surveys" for those years. Distribution for passenger cars and light duty trucks in other years computed by interpolation. Distribution of bus and other truck fleet according to model year computed assuming 10-percent attrition per annum of pre-1983 fleet for each year after 1984.

Factors for jet aircraft and piston powered aircraft were multiplied by data in EIA's Petroleum Supply Annual, ${ }^{63}$ and factors for recreational boats were used in conjunction with fuel consumption estimates in the Transportation Energy Data Book. 64

\section{Landfills}

Emissions Trends. During 1993, landfills were the single largest source of U.S. anthropogenic methane emissions. With gross emissions of 12.3 million metric tons and net emissions after flaring and energy recovery of 10.4 million metric tons, landfills produced 39 percent of all methane emissions in 1993 (Table 22). After decades of increase, gross emissions from landfills have begun to stabilize, as the amount of waste landfilled has declined due to recycling and source reduction. ${ }^{65}$ Meanwhile, net methane emissions from landfills have been steadily decreasing since 1990 due to somewhat more widespread methane recovery and increased flaring. However, annual estimates of methane emissions from landfills for the period 1987-1992 have been revised upward compared with those that appeared in last year's emissions report. This revision was the result of the inclusion, for the first time, of estimates of emissions from waste generated between 1940 and 1959.
The inclusion of this additional waste raises emissions estimates by about 400,000 metric tons annually. (For a discussion of the uncertainties associated with these estimates, see Appendix B.)

Methane Formation and Release. The decomposition of organic wastes begins with aerobic bacteria consuming oxygen while converting organic substances to carbon dioxide, heat, and water. This process continues until all available oxygen is depleted. After oxygen depletion, decomposition of organic material continues under anaerobic conditions (the absence of oxygen). In the absence of oxygen, anaerobic bacteria, including methanogens, begin digesting the waste and producing methane.

Methanogenic anaerobes require a fairly narrow range of temperature, $\mathrm{pH}$, and moisture content to maintain significant rates of activity. Because sanitary landfills in the United States are essentially closed systems designed to minimize the entry and exit of moisture, conditions within a landfill are largely a product of the composition of the waste itself. Thus, conditions are likely to vary both across different landfills and within a single landfill, producing methane at different rates and volumes.

\footnotetext{
${ }^{63}$ Energy Information Administration, Petroleum Supply Annual 1994, DOE/EIA-0340(94)/1, (Washington, DC, February 1995).

${ }^{64}$ S.C. Davis and S.G. Strang, Transportation Energy Data Book: Edition 14, ORNL-6743 (Oak Ridge, TN: Oak Ridge National Laboratory, Center for Transportation Analysis, March 1994).

${ }^{65}$ U.S. Environmental Protection Agency, Characterization of Municipal Solid Waste in the United States: 1994 Update, EPA 530-R-94-042 (Washington, DC, November 1994), p. 16; and Biocycle, "Nationwide Survey: The State of Garbage in America" (1988-1994).
} 
Table 22. U.S. Methane Emissions from Anaerobic Decomposition in Landfills, 1987-1994 (Million Metric Tons of Methane)

\begin{tabular}{c|r|r|r|r|r|r|r|r}
\hline Type & 1987 & 1988 & 1989 & 1990 & 1991 & 1992 & 1993 & 1994 \\
\hline Gross Emissions . . . . . . . . & 11.4 & 11.6 & 11.8 & 12.1 & 12.2 & 12.3 & 12.3 & NA \\
Methane Recovery (Energy) . . & 0.5 & 0.7 & 0.9 & 0.9 & 1.1 & 1.2 & 1.3 & NA \\
Methane Assumed Flared . . . . & 0.3 & 0.3 & 0.3 & 0.3 & 0.4 & 0.5 & 0.6 & NA \\
Net Emissions........... & 10.5 & 10.6 & 10.7 & 10.8 & 10.7 & 10.6 & 10.4 & NA \\
\hline
\end{tabular}

NA = not available.

Note: Data in this table are revised from the data contained in the previous EIA report, Emissions of Greenhouse Gases in the United States 1987-1992, DOE/EIA-0573 (Washington, DC, November 1994).

Sources: Municipal solid waste landfilled from Franklin Associates, Ltd., Characterization of Municipal Solid Waste in the United States, Worksheets, 1992 Update (prepared for the U.S. Environmental Protection Agency, Municipal Solid and Industrial Solid Waste Division, July 1992), Personal communication with Marjorie Franklin, Franklin Associates, Ltd., May 1994, and Biocycle, Nationwide Sunvey: The State of Garbage in America 1988-1994. Emissions calculations based on S.A. Thorneloe et al., "Estimate of Methane Emissions from U.S. Landfills," Prepared for the U.S. Environmental Protection Agency, Office of Research and Development, in departmental review (April 1994), and D. Augenstein, "The Greenhouse Effect and U.S. Landfill Methane," Global Environmental Change (December 1992), pp. 311-328. Methane recovered and flared from S.A. Thorneloe, "Landfill Gas Recovery Utilization-Options and Economics," presented at the Sixteenth Annual Conference by the Institute of Gas Technology on Energy from Biomass and Wastes, Orlando, Florida (March 5, 1992), and J. Pacey, "Methane Recovery from Landfills," presented at the 1995 Greenhouse Gas Emissions and Mitigation Research Symposium, Washington, DC (June 27-29, 1995).

Estimation Methods. Because it is nearly impossible to determine the exact composition of waste in every landfill in the United States, developing a national level estimate of methane emissions from landfills requires several assumptions about the average composition of landfilled waste. ${ }^{66}$ For the purpose of this report, the assumptions contained in the EMCON Methane Generation Model $^{67}$ were adopted with minor modifications. This model divides the waste in landfills into three categories: readily decomposable waste, moderately decomposable waste, and slowly decomposable waste, each with its own set of emissions characteristics. For any given year, the share of all waste landfilled falling into each category can be estimated, and its emissions consequences can be calculated.

Because of uncertainty in the estimates of the methane yields for each type of waste, the EMCON model provides both a high methane yield scenario and a low methane yield scenario. For each category of decomposable waste, a time lag until methane generation begins is estimated, as well as a time constant during which the methane yield of the waste is realized. The methane yield represents the total amount of methane that a given amount of waste will produce over its lifetime. Under the low methane yield scenario, slowly decomposing waste will begin producing methane after a 5year lag and will continue emitting over a 40 -year period. Thus, to estimate methane emissions from landfills for 1985, the amount of waste going to landfills in 1940 must be known.

Estimates of Waste Landfilled. Estimates of waste landfilled annually were derived using data from two sources: Franklin Associates and Biocycle magazine. ${ }^{68}$ Franklin Associates provide annual estimates of municipal solid waste landfilled beginning in 1960, and Biocycle provides annual refuse estimates beginning in 1988. The Franklin Associates data are developed using a model that estimates trash outputs based on production inputs. The Biocycle data are based on a survey of State agencies, and the State data often include industrial waste, construction and demolition waste, or sewage sludge. The EIA believes that the Biocycle data are more likely to be representative of the waste stream. ${ }^{69}$ For the period 1988-1993, Biocycle estimates of waste landfilled are, on average, 1.43 times greater than the Franklin Associates estimates. Thus, the Franklin Associates estimates for the years 1960-1993 have been adjusted upward by that ratio.

No reliable data have been compiled for waste landfilled prior to 1960 . Thus, estimates of waste landfilled between 1940 and 1959 were "backcast" using a regression equation developed with gross domestic product (GDP) and total population as independent variables

\footnotetext{
${ }^{66}$ See Appendix B of this report for a detailed discussion of uncertainty in the estimates.

${ }^{67}$ D. Augenstein, "The Greenhouse Effect and U.S. Landfill Methane," Global Environmental Change (December 1992), pp. $311-328$.

${ }^{68}$ Franklin Associates, Ltd., Characterization of Municipal Solid Waste in the United States: 1994 Update (prepared for U.S. Environmental Protection Agency, Office of Solid Waste and Emergency Response), p. 4; and "1994 Nationwide Survey: The State of Garbage in America," Biocycle (April 1994), p. 46.

${ }^{69}$ In April 1994, EIA hosted a methane emissions experts workshop to aid in the development of the estimates that appear in this report.
} 
and waste generated as the dependent variable. This backcast is somewhat uncertain, particularly for the years 1941-1945, when the United States was participating in World War II. Increased government spending inflated GDP during those years, and recycling campaigns in support of the U.S. war effort diverted waste away from landfills. However, the waste landfilled in those years has only a small effect on overall emissions estimates.

These estimation methods yield a solid waste landfilled figure of 167.5 million metric tons for 1993, a decrease of 2.5 million metric tons from 1992 and more than 43 million metric tons lower than the 1990 high of 210.6 million metric tons (see Table C10 in Appendix C). The steady decline in waste landfilled can be credited to increased refuse recycling, combustion, and, to a lesser extent, source reduction. According to Biocycle, some 19 percent of all waste generated in 1993 was recycled.

Overall Emissions Model Calibration. To apply the EMCON Methane Generation Model, waste landfilled was divided into two categories: waste buried in 105 landfills with gas recovery or disposal systems, and waste buried in all other landfills. Waste in place and methane emissions from landfills with gas recovery systems have been measured or estimated by Thorneloe et $\mathrm{al}^{70}$ Those landfills contained 9.4 percent of all waste in place in 1992 and had total methane emissions of 2.1 million metric tons during that year. In the absence of any empirical data, the share of waste landfilled in those 105 landfills was assumed to remain constant, although it is likely that their share has increased over time.

To derive an estimate of emissions from the 9.4 percent of waste assumed to be buried in the 105 landfills with methane recovery systems for years other than 1992, the EMCON model was calibrated to produce the 2.1 million metric tons of measured emissions for 1992. This calibration increased the default methane yields contained in the EMCON model by a factor of 1.96. The revised yields were used in conjunction with the model's original time lags and time constants. The increased yields are plausible, as it probably is most economical to install gas recovery systems at the landfills producing the greatest volumes of methane. Emissions from the remaining 90.6 percent of waste landfilled annually were calculated using the default methodology for the EMCON model (Table 23).
Methane Recovery. In 1992, there were 105 U.S. landfills with methane recovery systems in place. Approximately 1.7 million metric tons of methane were recovered at these landfills, with 1.2 million metric tons being combusted for energy use providing some 300 megawatts of electrical generating capacity. The remaining 500,000 metric tons of methane recovered were flared. In 1994, there were 130 known methane recovery systems in operation at landfills in the United States, with 360 megawatts of electrical generating capacity. ${ }^{71}$ Assuming a constant ratio of capacity to methane recovery for energy, 1.44 million metric tons of methane were recovered for energy in 1994. The 1993 estimate was interpolated from the 1992 and 1994 figures. Some 550,000 metric tons of methane is estimated to have been flared from recovery systems in 1993.

\section{Agricultural Sources}

Methane emissions from agricultural sources totaled 8.7 million metric tons in 1993, almost one-third of all anthropogenic methane emissions. This represents an increase of 410,000 metric tons or 5 percent since 1990 (Table 15). The growth can be traced to increases in emissions from livestock management, which account for 94 percent of all emissions from agricultural sources. Emissions from livestock management are the result of two processes: the breakdown of carbohydrates in the digestive tract of herbivores (enteric fermentation), and the decomposition of animal waste matter. The remainder of methane emissions from agricultural sources can be traced to rice cultivation and the burning of crop residues.

\section{Enteric Fermentation in Domesticated Animals}

Emissions Trends. Methane emissions from enteric fermentation in domesticated livestock are estimated at 5.5 million metric tons for 1993, representing 67 percent of all emissions from the management of livestock. Emissions from this source are up from 5.4 million metric tons in 1992 and more than 300,000 metric tons higher than in 1990 (Table 24). This increase can be traced to growth in the population of beef cattle.

Emissions from enteric fermentation have been increasing steadily since 1990, as the cyclical pattern in animal

\footnotetext{
${ }^{70}$ S.A. Thorneloe, M.R.J. Doorn, L.A. Stefanski, M.A. Barlaz, R.L. Peer, and D.L. Epperson, "Estimate of Methane Emissions From U.S. Landfills," prepared for U.S. Environmental Protection Agency, Office of Research and Development (April 1994).

${ }^{71} \mathrm{~J}$. Pacey, S.A. Thorneloe, and M. Doorn, "Methane Recovery From Landfills and an Overview of EPA's Research Program for Landfill Gas Utilization," presented at the 1995 Greenhouse Gas Emissions and Mitigation Research Symposium, U.S. Environmental Protection Agency (Washington, DC, June 27-29, 1995).
} 
Table 23. EMCON Methane Generation Model Parameters

\begin{tabular}{|c|c|c|c|c|}
\hline Waste Category & $\begin{array}{l}\text { Decomposable Portion } \\
\text { (Percent by Dry Weight) }\end{array}$ & $\begin{array}{c}\text { Methane Yield } \\
\text { (Cubic Feet per Pound) }\end{array}$ & $\begin{array}{l}\text { Lag Time } \\
\text { (Years) }\end{array}$ & Time Constant \\
\hline \multicolumn{5}{|l|}{ High Yield (Default) } \\
\hline Readily Decomposable & 4.0 & 4.50 & 0.2 & 3 \\
\hline Moderately Decomposable & 45.0 & 3.55 & 1.5 & 10 \\
\hline Slowly Decomposable ....... & 5.2 & 0.50 & 5.0 & 20 \\
\hline \multicolumn{5}{|l|}{ Low Yield (Default) } \\
\hline Readily Decomposable & 4.0 & 2.75 & 0.3 & 4 \\
\hline Moderately Decomposable & 45.0 & 1.95 & 2.0 & 20 \\
\hline Slowly Decomposable ....... & 5.2 & 0.29 & 5.0 & 40 \\
\hline \multicolumn{5}{|l|}{ High Yield (Modified) } \\
\hline Readily Decomposable & 4.0 & 8.82 & 0.0 & 3 \\
\hline Moderately Decomposable ... & 45.0 & 6.96 & 2.0 & 10 \\
\hline Slowly Decomposable ....... & 5.2 & 0.98 & 5.0 & 20 \\
\hline \multicolumn{5}{|l|}{ Low Y:8.d (Modified) } \\
\hline Readily Decomp:ssable & 4.0 & 5.39 & 0.0 & 4 \\
\hline Moderately Decomposable ... & 45.0 & 3.82 & 2.0 & 20 \\
\hline Slowly Decomposable ....... & 5.2 & 0.57 & 5.0 & 40 \\
\hline
\end{tabular}

Source: D. Augenstein, "The Greenhouse Effect and U.S. Landfill Methane," Global Environmental Change (December 1992), pp. 311-328.

Table 24. U.S: Methane Emissions from Enteric Fermentation in Domesticated Animals, 1987-1994 (Million Metric Tons of Methane)

\begin{tabular}{|c|c|c|c|c|c|c|c|c|}
\hline Animal Type & 1987 & 1988 & 1989 & 1990 & 1991 & 1992 & 1993 & 1994 \\
\hline Cattle & 4.80 & 4.81 & 4.80 & 4.84 & 5.02 & 5.10 & 5.18 & 5.40 \\
\hline Sheep & 0.14 & 0.14 & 0.14 & 0.15 & 0.15 & 0.14 & 0.13 & 0.12 \\
\hline Pigs & 0.08 & 0.08 & 0.08 & 0.08 & 0.09 & 0.09 & 0.09 & 0.09 \\
\hline Goats . & 0.02 & 0.02 & 0.02 & 0.02 & 0.02 & 0.02 & 0.02 & 0.02 \\
\hline Horses ..... & 0.04 & 0.04 & 0.04 & 0.04 & 0.04 & 0.04 & 0.04 & 0.04 \\
\hline Total $\ldots \ldots \ldots \ldots \ldots$ & 5.08 & 5.10 & 5.08 & 5.13 & 5.31 & 5.39 & 5.46 & 5.67 \\
\hline
\end{tabular}

Notes: Data in this table are revised from the data contained in the previous EIA report, Emissions of Greenhouse Gases in the United States 1987-1992, DOE/EIA-0573 (Washington, DC, November 1994). Totals may not equal sum of components due to independent rounding.

Sources: Cattle, sheep, and pig population data provided by the U.S. Department of Agriculture, National Agricultural Statistics Service, Livestock, Dairy and Poultry Service. Goat and horse population figures extrapolated from U.S. Department of Commerce, Bureau of the Census, Census of Agriculture, 1982, 1987, and 1992. Emissions calculations based on U.S. Environmental Protection Agency, Office of Air and Radiation, Anthropogenic Methane Emissions in the United States: Estimates for 1990 (Washington, DC, April 1993), and P.J. Crutzen, I. Aselmann, and W.S. Seiler, "Methane Production by Domestic Animals, Wild Ruminants, Other Herbivorous Fauna, and Humans," Tellus, Vol. 38B (1986), pp. 271-284.

populations has turned upward. The effect of the increases in animal populations has been magnified by simultaneous increases in animal size and productivity for the largest emitting group, cattle. In 1993, while populations continued to grow, animal sizes have, at least temporarily, stabilized.

Estimates of emissions from enteric fermentation have been revised for the period 1987-1992, compared with the estimates presented in last year's report. ${ }^{72}$ This change is the result of adjustments to population data provided by the U.S. Department of Agriculture. These revisions have mixed impacts on the overall emissions estimates, varying from year to year.

Methane Formation and Release. Methane production from enteric fermentation is greatest in ruminant animals, including cattle, sheep, and goats. These animals

${ }^{72}$ Energy Information Administration, Emissions of Greenhouse Gases in the United States 1987-1992, DOE/EIA-0573 (Washington, DC, November 1994), p. 37. 
possess a rumen, or forestomach, that allows them to digest the large quantities of cellulose found in plant material. Symbiotic microorganisms present in the rumen are responsible for this process. A small fraction ( 5 to 10 percent) ${ }^{73}$ of these microorganisms are methanogenic bacteria, which produce methane while removing hydrogen from the rumen. The majority (some 90 percent) of the methane produced by ruminant animals is released through eructation and normal respiration. The remainder is released as flatus.

Although nonruminant animals do produce methane from enteric fermentation in their large intestines, the production is small compared with that which occurs in ruminant animals. However, because of their size and relatively large populations, methane emissions from horses and swine are included in the emissions estimates for this report.

Estimation Methods. Methane production from the digestive processes of domesticated animals is a function of several variables, including quantity and quality of feed intake, the growth rate of the animal, its productivity (reproduction and/or lactation), and its mobility. In order to calculate methane emissions from enteric fermentation in domesticated animals, the animals are divided into distinct, relatively homogenous groups. For a representative animal in each group, feed quality and quantity, as well as growth rate, productivity, and activity levels, are estimated. These variables are combined to derive a methane emissions factor for that animal. The factor is then applied to the total population of the animal group to calculate an overall emissions estimate.

Population data for cattle, sheep, and swine are available from the U.S. Department of Agriculture (USDA), National Agricultural Statistics Service, Livestock, Dairy, and Poultry Branch. The USDA has recently revised the population estimates downward for the years 1980-1986 and 1989-1992. ${ }^{74}$ Population estimates for 1987-1988 have been revised upward. These revisions are reflected in overall emissions estimates that vary from previous EIA estimates. ${ }^{75}$ Population data for goats and horses were extrapolated from the U.S. Department of Commerce, Census of Agriculture for 1982, 1987, and $1992 .^{76}$

Cattle. The EPA developed emissions factors for several classes and subclasses within the U.S. cattle population as it was composed in 1990.77 The general taxonomy that EPA used is adopted here. First, cattle are separated into dairy and beef classes. Dairy cattle are further divided into three subclasses: replacement heifers 0-12 months old, replacement heifers 12-24 months old, and mature cows. Beef cattle are divided into six groups: replacements 0-12 months old, replacements 12-24 months old, mature cows, bulls, steers and heifers raised for slaughter under the weanling system, and steers and heifers raised for slaughter under the yearling system.

Because characteristics critical in determining energy intake and hence methane emissions for cattle, such as growth rates and milk production, have increased over the past decade, an attempt was made to incorporate these changes into emissions factors. Average slaughter weights for the respective classes of cattle as reported by USDA were used as a proxy for feed energy intake, thus scaling emissions factors to changes in slaughter weight. A more detailed discussion of the methods employed was included in last year's edition of this report. ${ }^{78}$ (For slaughter weights used, see Appendix C of this year's report, Table C12.) The slaughter weight adjusted emissions factors were applied to recently revised population data obtained from the USDA. For each subclass of cattle in a given year, a population figure was derived by averaging USDA estimates for January 1 , July 1 , and December 31 of that year. ${ }^{79}$ This method yielded an estimate of 5.2 million metric tons of methane emitted from enteric fermentation in cattle during 1993, up some 160,000 metric tons since 1990 .

Other Animals. In addition to cattle, estimates of methane emissions from enteric fermentation were derived for sheep, pigs, goats, and horses (Table 24). Like the

${ }^{73}$ U.S. Environmental Protection Agency, Office of Air and Radiation, Anthropogenic Methane Emissions in the United States: Estimates for 1990 (Washington, DC, April 1993), p. 5-3.

${ }^{74}$ U.S. Department of Agriculture, National Agricultural Statistics Service, Livestock, Dairy, and Poultry Branch, Cattle: Final Estimates, Sheep and Goats: Final Estimates, and Hogs and Pigs: Final Estimates (Washington, DC, various years).

${ }^{75}$ Energy Information Administration, Emissions of Greenhouse Gases in the United States 1987-1992, DOE/EIA-0573 (Washington, DC, November 1994), p. 37.

${ }^{76}$ U.S. Department of Commerce, Economics and Statistics Administration, Bureau of the Census, Census of Agriculture, United States Summary and State Data, Vol. 1, "Geographic Area Series," Part 51 (Washington, DC, 1982, 1987, and 1992).

7U.S. Environmental Protection Agency, Office of Air and Radiation, Anthropogenic Methane Emissions in the United States: Estimates for 1990 (Washington, DC, April 1993), p. 5-3.

${ }^{78}$ Energy Information Administration, Emissions of Greenhouse Gases in the United States 1987-1992, DOE/EIA-0573 (Washington, DC, November 1994), pp. 37-38.

${ }^{79}$ U.S. Department of Agriculture, National Agricultural Statistics Service, Livestock, Dairy, and Poultry Branch, Cattle: Final Estimates (Washington, DC, various years). 
method for estimating emissions from cattle, emissions from these animals were estimated by multiplying peranimal emissions factors by total animal populations. Emissions factors are a function of gross energy intake and methane yield for each animal class. Gross energy intake and methane yield estimates were drawn from the work of Crutzen et al. ${ }^{80}$ The emissions factors adopted were 13 kilograms methane yield per head per year for sheep, 1.5 kilograms for pigs, 8 kilograms for goats, and 18 kilograms for horses. Emissions factors for pigs and sheep were applied to population data taken from USDA estimates, while factors for goats and horses were used in conjunction with population estimates developed from the Census Bureau's Census of Agriculture for 1982, 1987, and 1992. Goat and horse populations in intervening years were estimated using straight-line interpolation. For 1993, population data were derived for goats and horses using straight-line extrapolation. Emissions factors were not adjusted for any changes in size or productivity for these animals.
Methane emissions from enteric fermentation in animals other than cattle totaled slightly more than 250,000 metric tons in 1993, virtually unchanged since 1990. Emissions reported for horses have been revised downward from last year's report, ${ }^{81}$ as additional data from the 1992 Census of Agriculture suggest a decline in horse populations between 1987 and 1992 rather than the previously estimated growth.

\section{Solid Waste of Domesticated Animals}

Emissions Trends. Methane emissions from the solid waste of domesticated animals are estimated at 2.7 million metric tons for 1993, unchanged from 1992, but up 100,000 metric tons from 1990 (Table 25). The rise is the result of increases in swine and cattle populations. In contrast to emissions from enteric fermentation, which are produced primarily by cattle, nearly half of all emissions from solid waste are produced by breeding and market swine. Poultry-specifically, broiler and

Table 25. U.S. Methane Emissions from the Solid Waste of Domesticated Animals, 1987-1994 (Thousand Metric Tons of Methane)

\begin{tabular}{|c|c|c|c|c|c|c|c|c|}
\hline Type of Animal & 1987 & 1988 & 1989 & 1990 & 1991 & 1992 & 1993 & 1994 \\
\hline Cattle & 1,219 & 1,224 & 1,217 & 1,215 & 1,233 & 1,234 & 1,229 & 1,197 \\
\hline Beef Cattle & 242 & 246 & 244 & 250 & 263 & 270 & 277 & 225 \\
\hline Dairy Cattle & 977 & 979 & 973 & 966 & 969 & 964 & 953 & 972 \\
\hline Swine & 1,242 & 1,261 & 1,223 & 1,234 & 1,306 & 1,312 & 1,308 & 1,332 \\
\hline Market Swine & 856 & 876 & 849 & 861 & 912 & 924 & 918 & 953 \\
\hline Breeding Swine & 386 & 385 & 374 & 373 & 394 & 388 & 390 & 379 \\
\hline Poultry & 150 & 150 & 152 & 157 & 161 & 167 & 172 & 179 \\
\hline Caged Layers & 88 & 85 & 83 & 83 & 84 & 86 & 88 & 90 \\
\hline Broilers & 63 & 65 & 69 & 73 & 77 & 81 & 84 & 89 \\
\hline Other Animals & 19 & 18 & 18 & 18 & 17 & 17 & 16 & 15 \\
\hline Sheep .......... & 5 & 5 & 5 & 5 & 5 & 5 & 5 & 4 \\
\hline Goats & 1 & 1 & 1 & 1 & 1 & 1 & 1 & 1 \\
\hline Horses & 13 & 13 & 12 & 12 & 11 & 11 & 11 & 10 \\
\hline Total $\ldots \ldots \ldots \ldots \ldots$ & 2,630 & 2,653 & 2,610 & 2,624 & 2,718 & 2,730 & 2,725 & 2,723 \\
\hline
\end{tabular}

Notes: Data in this table are revised from the data contained in the previous EIA report, Emissions of Greenhouse Gases in the United States 1987-1992, DOE/EIA-0573 (Washington, DC, November 1994). Totals may not equal sum of components due to independent rounding.

Sources: Population data for horses and goats extrapolated from U.S. Department of Commerce, Bureau of the Census, Census of Agriculture, 1982, 1987, and 1992. Population data for all other animals from U.S. Department of Agriculture, National Agricultural Statistics Service, Livestock, Dairy and Poultry Branch. Typical animal sizes from U.S. Environmental Protection Agency, Office of Air and Radiation, Anthropogenic Methane Emissions in the United States: Estimates for 1990, Report to Congress (Washington, DC, April, 1993). Cattle sizes adjusted by annual slaughter weight from U.S. Department of Agriculture, National Agricultural Statistics Service, Livestock, Dairy and Poultry Branch. Maximum methane production, and waste management systems used from L.M. Safley, M.E. Casada, et al., Global Methane Emissions from Livestock and Poultry Manure (Washington, DC: U.S. Environmental Protection Agency, February 1992), pp. 24-27. Methane Conversion Factors from Intergovernmental Panel on Climate Change, Greenhouse Gas Inventory Reference Manual, IPCC Guidelines for National Greenhouse Gas Inventories, Vol. 3 (Paris, France, 1995), pp. 4.33-4.41.

${ }^{80}$ P.J. Crutzen, I. Aselmann, and W.S. Seiler, "Methane Production by Domestic Animals, Wild Ruminants, Other Herbivorous Fauna, and Humans," Tellus, Vol. 38B (1986), pp. 274-275.

${ }^{81}$ Energy Information Administration, Emissions of Greenhouse Gases in the United States 1987-1992, DOE/EIA-0573 (Washington, DC, November 1994), p. 37. 
layer chickens-also account for a significant and rising share of methane emissions from solid waste. The remaining domesticated animals examined in this report, sheep, goats, and horses, contribute just 0.5 percent of total emissions from this source.

Estimates of emissions from the solid waste of domesticated animals have been revised from the estimates appearing in last year's report. ${ }^{82}$ This revision is the result of updated cattle and horse population data from the USDA and the Department of Commerce, respectively. The population changes create slightly higher emissions estimates for the period 1987-1989 and slightly lower emissions estimates (between 15,000 and 30,000 metric tons annually) for 1990-1992.

Methane Formation and Release. Methane is produced when methanogenic bacteria decompose the organic material in the solid waste of animals under anaerobic conditions. The amount of organic material susceptible to decomposition is described as the "volatile solids content." The volume of methane produced when a given amount of volatile solids decomposes under optimal anaerobic conditions is characterized as the maximum methane-producing capacity of the animal waste. Because conditions are rarely optimal, methane production is usually below the maximum.

In addition to varying as a function of the volatile solids content of the waste, methane emissions are driven by the manner in which the waste is managed. Liquid-based waste management systems provide an anaerobic environment as well as the moisture required for methanogenic bacterial cell production and acidity stabilization. ${ }^{83}$ In contrast, animal waste left to dry in the fields will decompose in an aerobic environment, minimizing methane production. The share of the maximum methane produced using a particular waste management system is represented by its methane conversion factor.

Estimation Methods. Estimates of emissions from the solid waste of domesticated animals were calculated by linking emissions to the volume of solid waste produced by a given animal, the volatile solids in that waste, and the system in which the waste is handled. The volume of waste produced is in turn a function of the animal's size, diet, and energy requirements. As a proxy for these variables, the typical animal mass of each class of animal was a principal determinant in developing emissions estimates. Typical animal masses for livestock and poultry inventoried in 1990 have been estimated by the EPA. ${ }^{84}$ These animal sizes were adopted directly for all animals except cattle. In an effort to capture changes in the size of cattle over the past decade, typical animal masses for the various classes of cattle were adjusted annually, based on average slaughter weight as reported by the USDA (see earlier section in this chapter on "Enteric Fermentation"). Volatile solids produced per kilogram of animal weight, maximum methane-producing capacity of each animal's waste, and share of waste handled in each management system for each animal type were adopted from the work of Safley et al..$^{85}$

Using these data, separate emissions factors were calculated by waste management system used, for beef cattle, dairy cattle, cattle on feed, breeding swine, market swine, broiler chickens, layer chickens, sheep, goats, and horses. Emissions factors for cattle, poultry, swine, and sheep were multiplied by population data obtained from the USDA. Average broiler chicken populations for each year were estimated by multiplying the estimated number of broiler chickens slaughtered annually by 0.1425 , based on the recommendation of the USDA's Economic Research Service. ${ }^{86}$ Population data for goats and horses were extrapolated from the Census of Agriculture for 1982, 1987, and $1992 .{ }^{87}$

\section{Rice Cultivation}

Emissions Trends. Methane emissions from flooded rice fields are estimated at 400,000 metric tons for 1993, nearly identical to 1990 , but approximately 40,000 metric tons lower than in 1992 (Table 15). Emissions in 1994 rebounded to some 460,000 metric tons, as good growing conditions across each of the rice-producing States resulted in 1.46 million hectares being harvested, 17 percent more than the previous year (Table 26).

\footnotetext{
${ }^{82}$ Energy Information Administration, Emissions of Greenhouse Gases in the United States 1987-1992, DOE/EIA-0573 (Washington, DC, November 1994), p. 39.

${ }^{83}$ U.S. Environmental Protection Agency, Office of Air and Radiation, Anthropogenic Methane Emissions in the United States: Estimates for 1990 (Washington, DC, April 1993), pp. 6-4-6-5.

${ }^{84}$ U.S. Environmental Protection Agency, Office of Air and Radiation, Anthropogenic Methane Emissions in the United States: Estimates for 1990 (Washington, DC, April 1993).

${ }^{85}$ L.M. Safley, M.E. Casada, J. Woodbury, and K. Roos, Global Methane Emissions from Livestock and Poultry Manure (Washington, DC: U.S. Environmental Protection Agency, February 1992), p. 18.

${ }^{86}$ Personal communication (May 1993).

${ }^{87}$ U.S. Department of Commerce, Economics and Statistics Administration, Bureau of the Census, Census of Agriculture, United States Summary and State Data, Vol. 1, "Geographic Area Series," Part 51 (Washington, DC, 1982, 1987, and 1992).
} 
Table 26. Area of Land Harvested for Rice and Estimated U.S. Methane Emissions from Flooded Rice Fields, 1987-1994

\begin{tabular}{|c|c|c|c|c|c|c|c|c|}
\hline Item & 1987 & 1988 & 1989 & 1990 & 1991 & 1992 & 1993 & 1994 \\
\hline Area Harvested (Thousand Hectares) & 1,039 & 1,302 & 1,202 & 1,267 & 1,241 & 1,380 & 1,243 & 1,455 \\
\hline $\begin{array}{l}\text { Methane Emissions-Low Estimate } \\
\text { (Thousand Metric Tons) } \ldots \ldots \ldots\end{array}$ & 105 & 131 & 121 & 127 & 124 & 138 & 126 & 147 \\
\hline $\begin{array}{l}\text { Methane Emissions-High Estimate } \\
\text { (Thousand Metric Tons) } \ldots \ldots \ldots\end{array}$ & 559 & 693 & 642 & 674 & 656 & 732 & 668 & 779 \\
\hline
\end{tabular}

Source: Rice area harvested data from U.S. Department of Agriculture, National Agricultural Statistics Service, Crop Production annual reports. Emissions calculations based on Intergovernmental Panel on Climate Change, Greenhouse Gas Inventory Reference Manual, IPCC Guidelines for National Greenhouse Gas Inventories, Vol. 3 (Paris, France, 1995), pp. 4.46-4.55.

Methane Formation and Release. Methane is produced by bacteria during the anaerobic decomposition of organic material in flooded rice fields. However, not all of the methane produced in rice fields is released to the atmosphere. Between 60 and 90 percent of the methane is oxidized by other bacteria in the soil, and additional methane is leached into groundwater. The majority of methane that does reach the atmosphere does so via diffusive transport through the rice plants during the growing season. Bubbling from the soil and diffusion through the water column are alternative, though less common, pathways for emissions.

Estimation Methods. The amount of methane produced in rice fields is controlled by a complex set of variables related to the biological and physical characteristics of the flooded soil, as well as agricultural management techniques. Studies have shown that emissions vary, depending on the temperature and $\mathrm{pH}$ of the soil, season of year, irrigation practices, and application of chemicals or organic matter. ${ }^{88}$

For the estimates presented in this report, studies of rice fields in California, ${ }^{89}$ Louisiana, ${ }^{90}$ and Texas $^{91}$ were used to derive a daily emissions rate range of 0.1065 to 0.5639 grams of methane per square meter of land cultivated. This range was chosen to incorporate the emissions variables typical of U.S. rice cultivation. The high and low ends of this range were applied to the growing season length and the haryested area for each State that produces rice. For Louisiana and Texas, where a second or "ratoon" crop of rice is produced after the initial harvest, the area harvested for the ratoon crop was included in the calculation.

\section{Burning of Crop Residues}

Emissions Trends. For 1993, methane emissions from the burning of crop residues are estimated at 110,000 metric tons, 20,000 metric tons below emissions for 1990. Emissions declined in 1993 due to an 8.7 million acre reduction in crops harvested as the result of widespread flooding in the Midwest. Moderate summer temperatures and precipitation during 1994 led to record high corn and soybean crops. Accordingly, preliminary estimates of emissions for 1994 increased to 150,000 metric tons (Table 15).

Methane Formation and Release. Crop residues are used for such purposes as fodder, land supplementation, and fuel. When residues are not put to such uses, they are sometimes burned. As with all types of biomass, crop residues are rich in carbon. (Actual carbon contents can range from 40 to 50 percent of dry matter. ${ }^{92}$ ) Consequently, burning these residues releases carbon dioxide and, due to incomplete combustion, small quantities of other gases, including methane. $^{93}$

\footnotetext{
${ }^{88}$ R. Sass, F. Fisher, S. Lewis, M. Jund, and F. Turner, "Methane Emissions from Rice Fields: Effect of Soil Properties," Global Biogeochemical Cycles, Vol. 8 (1994), p. 135.

${ }^{89}$ R.J. Cicerone, J.D. Shetter, and C.C. Delwiche, "Seasonal Variation of Methane Flux from a California Rice Paddy," Journal of Geophysical Research, Vol. 88 (1983), pp. 7203-7209.

${ }^{90}$ C.W. Lindau and P.K. Bolich, "Methane Emissions From Louisiana First and Ratoon Rice Crop," Soil Science, Vol. 156 (1993), pp. $42-48$.

${ }^{91}$ R.L. Sass, F.M. Fisher, and Y.B. Wang, "Methane Emissions From Rice Fields: The Effect of Floodwater Management," Global Biogeochemical Cycles, Vol. 6 (1992), pp. 249-262.

${ }_{92}$ A. Strehler and W. Stutzle, "Biomass Residues," in D.O. Hall and R. P. Overend (eds.), Biomass: Regenerable Energy (Chichester, UK: John Wiley and Sons, 1987), p. 85.

${ }^{93}$ These emissions are not considered to be a net release of carbon dioxide, given the uptake of carbon that occurs during the next cropping cycle's vegetative regrowth.
} 
Estimation Methods. Methane emissions from burning crop residues were estimated by determining the quantity of carbon released, then applying the appropriate emissions factor for methane. The calculation used to derive the amount of carbon released is a function of the amount, carbon content, and combustion efficiency of the burned residue (see Table C11 in Appendix C). In the United States, the practice of burning crop residues has not been inventoried, and some States have enacted legal bans on this type of burning. Due to the lack of data necessary for calculating emissions estimates, this report assumed that 10 percent of crop residues are burned, in keeping with the default methodology recommended for developed countries by the IPCC. ${ }^{94}$ This figure is highly uncertain, however, and the actual amount of burning in the United States is likely to be much lower. Because the estimate was created by multiplying crop production by a series of stable factors, all fluctuations in estimated emissions from residue burning can be attributed to annual variations in crop production.

\section{Industrial Processes}

On a global scale, methane emissions from industrial processes are minor when compared with emissions from the combustion of fossil fuels. The IPCC estimates that industrial processes account for 3 percent of total global methane emissions related to fossil fuels. ${ }^{95}$ In the United States, however, this figure is more significant, with methane from industrial processes accounting for 15 percent of all fossil-fuel-related methane emissions. All combustion-related methane emissions are detailed in a previous section of this chapter.

This report provides estimates of methane emitted as a byproduct of the production of certain chemicals and of iron and steel. In 1993, these processes produced a total of 123,000 metric tons of methane, divided nearly equally between chemical and iron and steel production (Table 27). Emissions from industrial processes in the United States have remained nearly unchanged for the better part of a decade, as increases in emissions from

Table 27. U.S. Methane Emissions from Industrial Processes, 1987-1994 (Thousand Metric Tons of Methane)

\begin{tabular}{|c|c|c|c|c|c|c|c|c|}
\hline Source & 1987 & 1988 & 1989 & 1990 & 1991 & 1992 & 1993 & P1994 \\
\hline \multicolumn{9}{|l|}{ Chemical Production } \\
\hline Ethylene ........ & 16 & 17 & 16 & 17 & 18 & 18 & 19 & 22 \\
\hline Ethylene Dichloride ... & 2 & 2 & 2 & 3 & 2 & 3 & 3 & 3 \\
\hline Styrene $\ldots \ldots \ldots \ldots$ & 15 & 16 & 15 & 15 & 15 & 16 & 18 & 20 \\
\hline Methanol ........ & 7 & 7 & 7 & 8 & 8 & 8 & 9 & 10 \\
\hline Carbon Black ...... & 14 & 14 & 15 & 14 & 13 & 15 & 16 & 17 \\
\hline Total $\ldots \ldots \ldots \ldots \ldots$ & 53 & 57 & 55 & 56 & 57 & 60 & 65 & 72 \\
\hline \multicolumn{9}{|l|}{ Iron and Steel Production } \\
\hline Coke $^{\mathrm{a}} \ldots \ldots \ldots \ldots$ & 10 & 11 & 11 & 11 & 9 & 9 & 9 & NA \\
\hline Sinter . . . . . . . . . . . & 7 & 8 & 7 & 6 & 5 & 6 & 6 & NA \\
\hline Pig Iron $\ldots \ldots \ldots \ldots \ldots$ & 40 & 46 & 46 & 45 & 40 & 43 & 43 & 44 \\
\hline Total $\ldots \ldots \ldots \ldots \ldots \ldots$ & 57 & 64 & 64 & 62 & 54 & 57 & 58 & NA \\
\hline Total Industrial Processes $\ldots \ldots$ & 110 & 121 & 119 & 117 & 111 & 118 & 123 & NA \\
\hline
\end{tabular}

${ }^{a}$ Based on total U.S. production of metallurgical coke, including non-iron and steel uses.

$P=$ preliminary data. $N A=$ not available.

Note: Totals may not equal sum of components due to independent rounding.

Sources: American Iron and Steel Institute, Annual Statistical Report (Washington, DC, various years); Chemical Manufacturers Association, U.S. Chemical Industry Statistical Handbook (Washington, DC, various years), p. 223; Intergovernmental Panel on Climate Change, Greenhouse Gas Inventory Reference Manual, IPCC Guidelines for National Greenhouse Gas Inventories, Vol. 3 (Paris, France, 1995), p. 2.6.

\footnotetext{
${ }^{94}$ Intergovernmental Panel on Climate Change, Greenhouse Gas Inventory Reference Manual, IPCC Guidelines for National Greenhouse Gas Inventories, Vol. 3 (Paris, France, 1994), p. 4.71.

${ }_{95}^{95}$ Intergovernmental Panel on Climate Change, Greenhouse Gas Inventory Reference Manual, IPCC Guidelines for National Greenhouse Gas Inventories, Vol. 3 (Paris, France, 1994), p. 2.7.
} 
chemical production have been offset by decreases in emissions from iron and steel production.

\section{Chemical Production}

Emissions Trends. The manufacture of ethylene, ethylene dichloride, styrene, methanol, and carbon black resulted in the emission of 65,000 metric tons of methane during 1993 (Table 27). Emissions from this source have risen by 16 percent since 1990, due to increased demand for chemicals as the economy has expanded.

Methane Formation and Release. The process of feedstock cracking is used in the production of certain chemicals. The feedstock is an organic compound, and when it is heated, its molecular bonds are "cracked." Depending on the type of feedstock used and the temperature of the reaction, various permutations of fractures may occur, resulting in the production of specific chemicals. Methane is one of the byproducts that may be formed in this process.

Estimation Methods. The IPCC has published emissions factors for methane emitted during the manufacture of ethylene, ethylene dichloride, styrene, methanol, and carbon black. ${ }^{96}$ Multiplying the emissions factors by annual production figures provides the emissions estimates for each chemical. There is a degree of uncertainty in the emissions estimates. The emissions factors used in the calculations were developed for global application, but U.S. manufacturers, while complying with air pollution regulations to control emissions of volatile organic compounds, may also be reducing the amount of methane that is released.

\section{Iron and Steel Production}

Emissions Trends. In 1993, 58,000 metric tons of methane were emitted during the manufacture of iron and steel (Table 27). Emissions have declined slightly over the past several years, from a 1989 peak of 64,000 metric tons.

Methane Formation and Release. Coke, sinter, and pig iron are the basic materials for production of iron and steel. In order to estimate methane emissions from this source, the individual processes for manufacturing those inputs must be examined. When coal is heated in the absence of oxygen, impurities are driven off and coke is produced. Methane is one of the gaseous byproducts of this process. Pollution controls required on coke ovens to reduce emissions of volatile organic compounds typically eliminate methane as well. However, some leakage may occur. Coke is then combined with iron ore and flux materials to form sinter. In this process, the coke is burned to create heat, causing the sinter to agglomerate. Methane is emitted as a byproduct of the agglomeration. Coke and iron (in the form of ore, pellets, and sinter) are then added to flux materials in a blast furnace and reduced into iron, slag, and exhaust gases (including methane). The exhaust gases are recycled as fuel, but small amounts may be vented.

Estimation Methods. Emissions factors for the production of coke, sinter, and pig iron recommended by the IPCC $^{97}$ were multiplied by production data supplied by the American Iron and Steel Institute ${ }^{98}$ to produce emissions estimates.

\footnotetext{
${ }^{96}$ Intergovernmental Panel on Climate Change, Greenhouse Gas Inventory Reference Manual, IPCC Guidelines for National Greenhouse Gas Inventories, Vol. 3 (Paris, France, 1994), p. 2.12.

${ }^{97}$ Intergovernmental Panel on Climate Change, Greenhouse Gas Inventory Reference Manual, IPCC Guidelines for National Greenhouse Gas Inventories, Vol. 3 (Paris, France, 1994), p. 2.6.

${ }^{98}$ American Iron and Steel Institute, Annual Statistical Report (Washington, DC, 1993).
} 


\section{Nitrous Oxide}

\section{Overview}

One of the least-studied greenhouse gases to date, nitrous oxide is an important contributor to atmospheric warming because of its 100-year global warming potential of $320 . .^{99}$ Although there are many known natural and anthropogenic sources, emissions of nitrous oxide have been difficult to quantify on a global scale.

This year, emissions estimates in this report have been expanded to include burning of crop residues and stationary source combustion from residential, industrial, and electric utility energy use. As indicated in Table 28, the Energy Information Administration (EIA) estimates that anthropogenic nitrous oxide emissions in the United States totaled 459,000 metric tons in 1993. Sources for which data are available show increased emissions in 1994 (estimates for mobile source combustion are not yet available).
Most anthropogenic nitrous oxide emissions in the United States can be attributed to agricultural and energy-related sources. In particular, fertilizer use (which amplifies the natural flux of nitrous oxide from soil) and vehicular fuel combustion combine to account for approximately 70 percent of estimated emissions. The dramatic growth in emissions from energy are largely responsible for the increase in anthropogenic nitrous oxide emissions observed since the early 1980s (Figure 6). In recent years, emissions from energy use have risen at a much slower rate, due to changes in the composition of the motor vehicle fleet. Cars manufactured in the 1980s exhibited significantly higher nitrous oxide emissions rates than the majority of cars being retired from the fleet at that time. Beginning in 1990, however, the emissions rate for new cars declined below that of retiring vehicles. ${ }^{100}$ Emissions of nitrous oxide in the United States will probably continue to rise as consumption of fertilizer and the proportion of the motor vehicle fleet using catalytic converters increase.

Table 28. Estimated U.S. Emissions of Nitrous Oxide, 1987-1994

(Thousand Metric Tons of Nitrous Oxide)

\begin{tabular}{|c|c|c|c|c|c|c|c|c|}
\hline Source & 1987 & 1988 & 1989 & 1990 & 1991 & 1992 & 1993 & 1994 \\
\hline \multicolumn{9}{|l|}{ Agriculture } \\
\hline Fertilizer . & 148 & 150 & 154 & 159 & 162 & 163 & 171 & 180 \\
\hline Crop Residue Burning & 5 & 4 & 5 & 5 & 5 & 5 & 4 & 6 \\
\hline Total $\ldots . \ldots \ldots$ & 152 & 154 & 159 & 164 & 167 & 168 & 176 & 186 \\
\hline \multicolumn{9}{|l|}{ Energy Use } \\
\hline Mobile Sources. & 117 & 133 & 139 & 144 & 147 & 148 & 146 & NA \\
\hline Stationary Combustion & 36 & 38 & 38 & 37 & 37 & 37 & 38 & 39 \\
\hline Total & 153 & 170 & 176 & 181 & 184 & 185 & 184 & NA \\
\hline Industrial Sources & 90 & 95 & 100 & 98 & 100 & 96 & 103 & 108 \\
\hline Total $\ldots \ldots \ldots \ldots \ldots \ldots \ldots \ldots \ldots$ & 390 & 416 & 431 & 438 & 446 & 444 & 459 & NA \\
\hline
\end{tabular}

$N A=$ not available.

Notes: Data in this table are revised from the data contained in the previous EIA report, Emissions of Greenhouse Gases in the United States 1987-1992, DOE/EIA-0573 (Washington, DC, November 1994). Totals may not equal sum of components due to independent rounding.

Sources: Estimates presented in this chapter. Crop residue burning-U.S. Department of Agriculture, National Agricultural Statistics Service, Crop Production annual reports. Emissions calculations based on Intergovernmental Panel on Climate Change, Greenhouse Gas Inventory Reference Manual, IPCC Guidelines for National Greenhouse Gas Inventories, Vol. 3 (Paris, France, 1995), pp. 4.69-4.73.

\footnotetext{
${ }^{99}$ Intergovernmental Panel on Climate Change, Climate Change 1994: Radiative Forcing of Climate Change (Cambridge, UK: Cambridge University Press, 1995), p. 33.

${ }^{100}$ The number of vehicle miles traveled (VMT) has risen since the early 1980s. The decline in the emissions rate for the latest model cars has been outweighed by increases in VMT. Therefore, overall emissions from vehicles continue to increase.
} 
Figure 6. U.S. Emissions of Nitrous Oxide by Source, 1980-1994

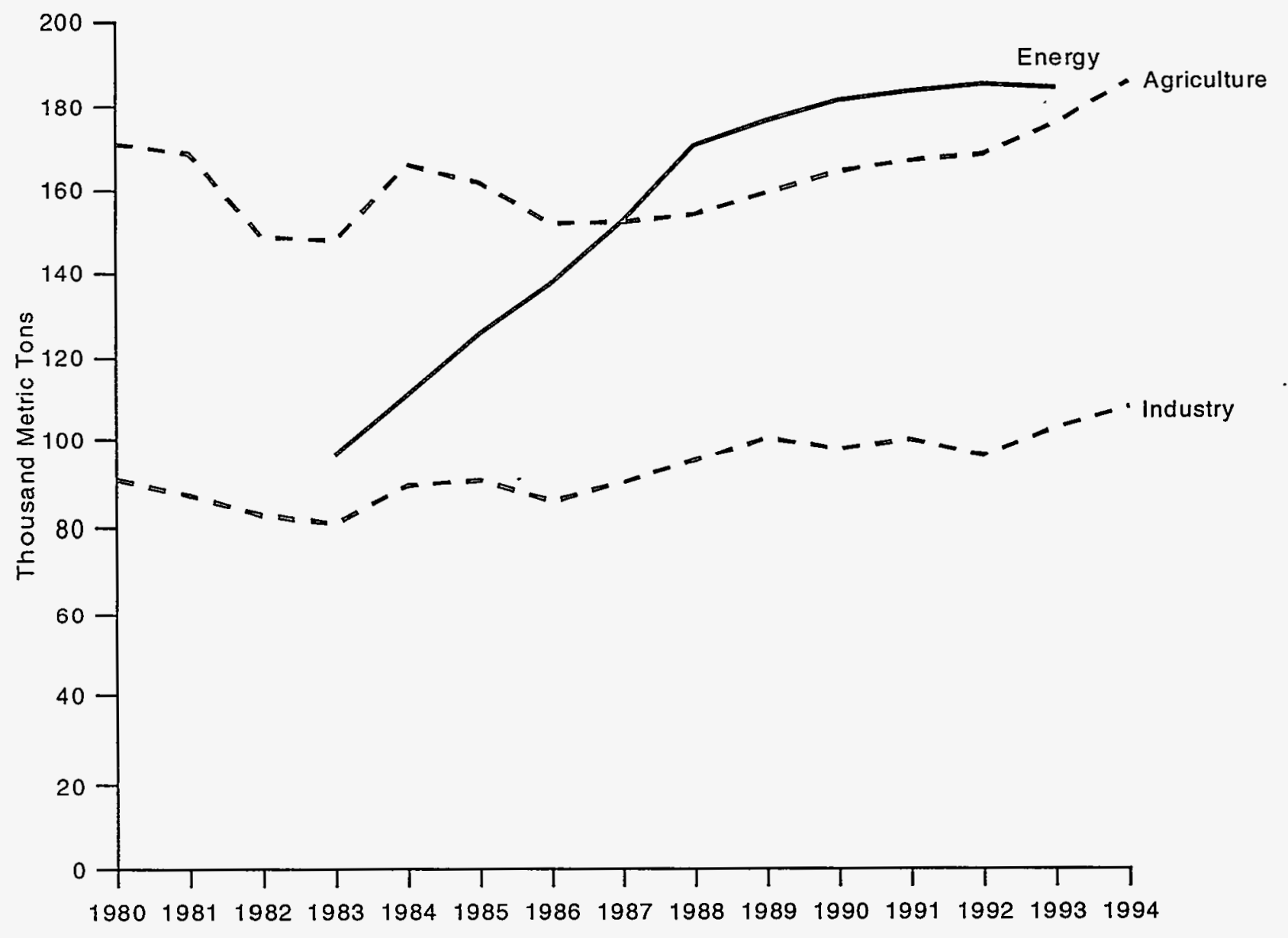

Source: Estimates presented in this chapter.

\section{Agriculture}

On a global scale, agricultural practices contribute approximately 70 percent of anthropogenic nitrous oxide emissions. ${ }^{101}$ Application of fertilizer is the principal source of agriculture-related emissions in the United States. The disposal of crop residues by burning also produces nitrous oxide that is released into the atmosphere; however, the amount is relatively minor.

\section{Fertilizer Use}

Nitrous oxide emissions occur naturally as a result of nitrification and denitrification processes in soil. When nitrogen-based fertilizers are added to the soil, the emissions generally increase. ${ }^{102}$ Some studies have shown that different types of fertilizer may produce disparate levels of nitrous oxide emissions, but another group of researchers has concluded that there is no correlation between emissions rate and fertilizer

\footnotetext{
${ }^{101}$ A.R. Mosier, "Nitrous Oxide Emissions from Agricultural Soils," in A.R. van Amstel (ed.), International IPCC Workshop Proceedings: Methane and Nitrous Oxide, Methods in National Emissions Inventories and Options for Control (Bilthoven, Netherlands: RIVM, 1993 ), p. 277.

${ }^{102}$ A.F. Bouwman, "Exchange of Greenhouse Gases Between Terrestrial Ecosystems and the Atmosphere," in A.F. Bouwman (ed.), Soils and the Greenhouse Effect (New York, NY: John Wiley and Sons, 1990).
} 
type. ${ }^{103} \mathrm{~A}$ variety of other factors, including certain soil properties and moisture content, are known to influence the rate of emissions. Although these factors have been identified, they have not been systematically quantified, and there are no available data that would allow them to be incorporated into emissions estimates.

For this report, nitrous oxide emissions from fertilizer use were estimated using a simplified calculation suggested by A.R. Mosier. ${ }^{104}$ Emissions factors ranging in order of magnitude from 0.001 to 0.1 were applied to the nitrogen content of fertilizer consumed annually in the United States, producing low, median, and high estimates. In 1994, the median estimate (which assumes that 1 percent of the nitrogen in fertilizer is emitted as nitrous oxide) indicates that 180,000 metric tons of nitrous oxide was released into the atmosphere as a result of fertilization practices (Table 29). Estimates for prior years have been modified from those in last year's report to represent the nitrogen content of annual fertilizer consumption for the calendar year.

\section{Crop Residue Burning}

As described in Chapter 3, incomplete combustion of agricultural wastes produces various gases, including methane and nitrous oxide. Nitrous oxide emissions from crop residue burning are calculated by first determining the amount of nitrogen released from the burned residues, then applying an emissions factor for nitrous oxide. The quantity of crop residues subjected to burning is part of the computation used to derive the quantity of nitrogen released. The EIA is not aware of any reliable information on the extent of this practice.
For this reason, the EIA has adopted the Intergovernmental Panel on Climate Change (IPCC) estimate that, in developed countries, 10 percent of crop wastes are burned. ${ }^{105}$ This estimate is uncertain because burning of crop residues in the United States is uncommon and is actually prohibited in many States for air quality reasons. Therefore, this value probably represents a maximum quantity.

In 1994, burning of crop residues produced emissions of 6,000 metric tons of nitrous oxide (Table 28). Large fluctuations in annual crop production result in negligible variations in emissions. Since 1987, the amount of nitrous oxide emitted as a result of this agricultural practice has been roughly stable.

\section{Energy Use}

Nitrous oxide emissions are also produced as a byproduct of fuel combustion in both mobile and stationary sources. In 1993, energy-related emissions totaled 184,000 metric tons, or 40 percent of total U.S. anthropogenic nitrous oxide emissions (Table 28). The estimates indicate that emissions from energy use have been increasing over time, nearly doubling since 1983.

\section{Mobile Combustion}

Nitrous oxide emissions from motor vehicles are influenced by a variety of factors, including fleet size, vehicle miles traveled (VMT), and emission control technologies. Emissions estimates are based on fleet data from the American Automobile Manufacturers

Table 29. U.S. Nitrous Oxide Emissions from Nitrogen Fertilizer Use, 1987-1994

(Thousand Metric Tons of Nitrous Oxide)

\begin{tabular}{c|r|r|r|r|r|r|r|r}
\hline Source & 1987 & 1988 & 1989 & 1990 & 1991 & 1992 & 1993 & 1994 \\
\hline Low Estimate $\ldots \ldots \ldots \ldots \ldots \ldots$ & 15 & 15 & 15 & 16 & 16 & 16 & 17 & 18 \\
Median Estimate . . . . . . . & 148 & 150 & 154 & 159 & 162 & 163 & 171 & 180 \\
High Estimate . . . . . . . . & 1,477 & 1,504 & 1,545 & 1,594 & 1,620 & 1,628 & 1,713 & 1,802 \\
\hline
\end{tabular}

Note: Data in this table are revised from the data contained in the previous EIA report, Emissions of Greenhouse Gases in the United States 1987-1992, DOE/EIA-0573 (Washington, DC, November 1994).

Sources: Emissions coefficients from Intergovernmental Panel on Climate Change, Methane and Nitrous Oxide Methods in National Emissions Inventories and Options for Control, Proceedings, Research for Man and Environment (Netherlands, February 1993), p. 274. Total nitrogen content of U.S. fertilizer consumption from Tennessee Valley Authority.

\footnotetext{
${ }^{103}$ A.R. Mosier, "Nitrous Oxide Emissions from Agricultural Soils," in A.R. van Amstel (ed.), International IPCC Workshop Proceedings: Methane and Nitrous Oxide, Methods in National Emissions Inventories and Options for Control (Bilthoven, Netherlands: RIVM, 1993), p. 274.

${ }^{104}$ A.R. Mosier, "Nitrous Oxide Emissions from Agricultural Soils," in A.R. van Amstel (ed.), International IPCC Workshop Proceedings: Methane and Nitrous Oxide, Methods in National Emissions Inventories and Options for Control (Bilthoven, Netherlands: RIVM, 1993 ), p. 281.

${ }^{105}$ Intergovernmental Panel on Climate Change, Greenhouse Gas Inventory Reference Manual, IPCC Guidelines for National Greenhouse Gas Inventories, Vol. 3 (Paris, France, 1994), p. 4.71.
} 
Association and VMT data from the Federal Highway Administration and the EIA in its Residential Transportation Energy Consumption Survey (RTECS). ${ }^{106}$ In addition, there is general agreement in research studies that vehicles equipped with catalytic converters to reduce emissions of nitrogen oxides, carbon monoxide, and nonmethane volatile organic compounds emit up to 20 times more nitrous oxide than comparable vehicles without such emission control devices. ${ }^{107}$ Data have not been collected regarding the precise number of vehicles with particular types of catalytic converters; however, changing emission control technologies are factored into these estimates, based on assigning technologies by model year of motor vehicles. Emissions factors used in the estimation calculation are those recommended by the IPCC. ${ }^{108}$

Emissions from air, rail, and water transportation sources and from farm and construction equipment are included as "Other Mobile Sources" in Table 30. Estimates for each of these sources were derived by applying specific emissions factors to energy consumption data as reported by the EIA.
Nitrous oxide emissions from mobile source combustion were estimated to be 146,000 metric tons in 1993 (Table 30). Approximately 89 percent of the emissions can be attributed to motor vehicles. Driven by increases in VMT, fleet size, and share of fleet with catalytic converters, emissions from mobile source combustion have increased by 25 percent since 1987.

\section{Stationary Combustion}

During combustion, nitrous oxide is produced as a result of chemical interactions between nitric oxide and other combustion products. With most conventional combustion systems, high temperatures limit the quantity of nitrous oxide that escapes; therefore, emissions from these systems are typically low. The emissions factors used to calculate the estimates presented in this report are those recommended by the IPCC as derived from studies of numerous conventional systems. ${ }^{109}$ The emissions factors differ from those used in previous years; therefore, emissions estimates may also be different from those presented in last year's report.

Table 30. U.S. Nitrous Oxide Emissions from Mobile Sources, 1987-1994

(Thousand Metric Tons of Nitrous Oxide)

\begin{tabular}{|c|c|c|c|c|c|c|c|c|}
\hline Item & 1987 & 1988 & 1989 & 1990 & 1991 & 1992 & 1993 & 1994 \\
\hline \multicolumn{9}{|l|}{ Motor Vehicles } \\
\hline Passenger Cars & 68 & 79 & 83 & 86 & 88 & 91 & 90 & NA \\
\hline Buses & * & * & * & * & * & * & * & NA \\
\hline Motorcycles & * & * & * & * & * & * & * & NA \\
\hline Light-Duty Trucks $\ldots \ldots \ldots \ldots$ & 27 & 31 & 33 & 34 & 35 & 33 & 33 & NA \\
\hline Other Trucks & 6 & 6 & 7 & 6 & 6 & 6 & 6 & NA \\
\hline Total $\ldots \ldots \ldots \ldots \ldots \ldots$ & 101 & 116 & 122 & 127 & 130 & 131 & 130 & NA \\
\hline Other Mobile Sources & 16 & 16 & 16 & 17 & 17 & 17 & 17 & NA \\
\hline Total Mobile Sources $\ldots . . . \ldots$ & 117 & 133 & 139 & 144 & 147 & 148 & 146 & NA \\
\hline
\end{tabular}

*Less than 500 metric tons of nitrous oxide.

NA = not available.

Notes: Data in this table are revised from the data contained in the previous EIA report, Emissions of Greenhouse Gases in the United States 1987-1992, DOE/EIA-0573 (Washington, DC, November 1994). Totals may not equal sum of components due to independent rounding.

Sources: Calculations based on vehicle miles traveled from U.S. Department of Transportation, Federal Highway Statistics, various years, Table VM-1. Vehicle emissions coefficients from Intergovernmental Panel on Climate Change, Greenhouse Gas Inventory Reference Manual, IPCC Guidelines for National Greenhouse Gas Inventories, Vol. 3 (Paris, France, 1995), pp. 1.64-1.68.

${ }^{106}$ VMT figures were taken from RTECS for 1983, 1985, 1988 and 1991, the most recent years in which the survey was administered. For all other years, VMT figures were derived by using fleet age data from the AAMA to distribute the Federal Highway Administration's VMT data, and scaling the results to the RTECS figures.

${ }^{107}$ J.C. Kramlich and W.P. Linak, "Nitrous Oxide Behavior in the Atmosphere, and in Combustion and Industrial Systems," Progress in Energy and Combustion Science, Vol. 20 (1994), p. 196.

${ }^{108}$ Intergovernmental Panel on Climate Change, Greenhouse Gas Inventory Reference Manual, IPCC Guidelines for National Greenhouse Gas Inventories, Vol. 3 (Paris, France, 1995), pp. 1.63-1.68.

${ }^{109}$ G.G. De Soete, "Nitrous Oxide from Combustion and Industry: Chemistry, Emissions and Control," in A.R. van Amstel (ed.), International IPCC Workshop Proceedings: Methane and Nitrous Oxide, Methods in National Emissions Inventories and Options for Control (Bilthoven, Netherlands: RIVM, 1993), pp. 287-337. 
Emissions were estimated by applying the emissions factors for coal, oil, and natural gas to EIA's consumption data for each of those fuels in the commercial, residential, industrial, and electric utility sectors. In 1994 , nitrous oxide emissions from stationary combustion sources rose slightly to 39,000 metric tons (Table 31). Combustion systems powered by coal clearly produce the most nitrous oxide, approximately 76 percent of annual emissions. As a sector, electric utilities consistently account for more than one-half of total emissions. Estimated nitrous oxide emissions from stationary combustion have increased by only 8 percent since 1987.

\section{Industrial Processes}

Nitrous oxide is also emitted as a byproduct of certain chemical production processes. Table 32 provides estimates of emissions from the production of adipic acid and nitric acid, the two principal known sources. Emissions from the combination of these two processes have increased by 20 percent since 1987.

\section{Adipic Acid Production}

Adipic acid is a fine, white powder that is used primarily in the manufacture of nylon fibers and plastics,

Table 31. U.S. Nitrous Oxide Emissions from Stationary Combustion Sources, 1987-1994 (Thousand Metric Tons of Nitrous Oxide)

\begin{tabular}{|c|c|c|c|c|c|c|c|c|}
\hline Source & 1987 & 1988 & 1989 & 1990 & 1991 & 1992 & 1993 & 1994 \\
\hline Commercial . . . . . . . . . . . & 1 & 1 & 1 & 1 & 1 & 1 & 1 & 1 \\
\hline Coal . . . . . . . . . . . & * & * & * & * & * & * & $\star$ & * \\
\hline$\ldots \ldots \ldots \ldots \ldots$ & 1 & 1 & 1 & 1 & 1 & 1 & - & * \\
\hline Natural Gas . . . . . . . . . . . & * & * & * & * & * & * & * & * \\
\hline Residential $\ldots \ldots \ldots \ldots \ldots \ldots$ & 2 & 2 & 2 & 1 & 1 & 1 & 1 & 2 \\
\hline Coal $\ldots \ldots \ldots \ldots \ldots \ldots$ & 1 & 1 & 1 & 1 & 1 & 1 & 1 & 1 \\
\hline Fuel Oil & * & 1 & 1 & - & * & 1 & 1 & 1 \\
\hline Natural Gas .......... & * & 1 & 1 & * & * & 1 & 1 & 1 \\
\hline Industrial $\ldots \ldots \ldots \ldots \ldots \ldots$ & 10 & 10 & 10 & 10 & 10 & 10 & 10 & 10 \\
\hline Coal $\ldots \ldots \ldots \ldots \ldots \ldots$ & 4 & 4 & 4 & 4 & 4 & 4 & 4 & 4 \\
\hline$\ldots \ldots \ldots \ldots \ldots$ & 5 & 5 & 5 & 5 & 5 & 5 & 5 & 6 \\
\hline Natural Gas $\ldots \ldots \ldots \ldots \ldots$ & 1 & 1 & 1 & 1 & 1 & 1 & 1 & 1 \\
\hline Electric Utility $\ldots \ldots \ldots \ldots \ldots$ & 23 & 25 & 25 & 25 & 25 & 25 & 26 & 26 \\
\hline Coal $\ldots \ldots \ldots \ldots \ldots \ldots$ & 22 & 23 & 24 & 24 & 24 & 24 & 25 & 25 \\
\hline Fuel Oil $\ldots \ldots \ldots \ldots \ldots \ldots$ & 1 & 1 & 1 & 1 & 1 & 1 & 1 & 1 \\
\hline Natural Gas $\ldots \ldots \ldots \ldots \ldots$ & $\star$ & * & * & * & - & * & * & * \\
\hline \multicolumn{9}{|l|}{ Fuel Totals } \\
\hline Coal... & 27 & 28 & 28 & 28 & 28 & 28 & 29 & 29 \\
\hline Fuel Oil & 8 & 8 & 8 & 7 & 7 & 7 & 7 & 8 \\
\hline Natural Gas ............. & 2 & 2 & 2 & 2 & 2 & 2 & 2 & 2 \\
\hline Total (All Fuels) $\ldots \ldots \ldots \ldots \ldots$ & 36 & 38 & 38 & 37 & 37 & 37 & 38 & 39 \\
\hline
\end{tabular}

"Less than 500 metric tons of nitrous oxide.

$\mathrm{NA}=$ not available.

Notes: Data in this table are revised from the data contained in the previous EIA report, Emissions of Greenhouse Gases in the United States 1987-1992, DOE/EIA-0573 (Washington, DC, November 1994).

Totals may not equal sum of components due to independent rounding.

Sources: Emissions coefficients from Intergovernmental Panel on Climate Change, Greenhouse Gas Inventory Reference Manual, IPCC Guidelines for National Greenhouse Gas Inventories, Vol. 3 (Paris, France, 1995), p. 1.50. Energy consumption data from Energy Information Administration, State Energy Data Report 1993, DOE/EIA-0214(93) (Washington, DC, May 1995); and Monthly Energy Review, DOE/EIA-0035(95/07) (Washington, DC, July 1995). 
Table 32. U.S. Nitrous Oxide Emissions from Industrial Processes, 1987-1994

(Thousand Metric Tons of Nitrous Oxide)

\begin{tabular}{|c|c|c|c|c|c|c|c|c|}
\hline Source & 1987 & 1988 & 1989 & 1990 & 1991 & 1992 & 1993 & 1994 \\
\hline \multicolumn{9}{|l|}{ Adipic Acid } \\
\hline Controlled Sources . . . . . . . . . . & 3 & 3 & 3 & 3 & 4 & 3 & 4 & 4 \\
\hline Uncontrolled Sources .......... & 47 & 48 & 51 & 51 & 53 & 49 & 53 & 56 \\
\hline Total $\ldots \ldots \ldots \ldots \ldots \ldots$ & 50 & 51 & 55 & 54 & 57 & 52 & 56 & 60 \\
\hline Nitric Acid . . . . . . . . . . . . & 39 & 43 & 45 & 44 & 43 & 44 & 46 & 48 \\
\hline Total Known Industrial Sources . . . & 90 & 95 & 100 & 98 & 100 & 96 & 103 & 108 \\
\hline
\end{tabular}

Notes: Data in this table are revised from the data contained in the previous EIA report, Emissions of Greenhouse Gases in the United States 1987-1992, DOE/EIA-0573 (Washington, DC, November 1994). Totals may not equal sum of components due to independent rounding.

Sources: Adipic acid production from Chemical and Engineering News, annual report on "Top 50 Industrial Chemicals" (April issue, various years). Nitric acid production from Chemical Manufacturer's Association, Chemical Industry Statistical Handbook (Washington, DC, 1994). Adipic acid emissions coefficient from M. Thiemens and W. Trogler, "Nylon Production: An Unknown Source of Atmospheric Nitrous Oxide," Science, Vol. 251 (February 22, 1991), p. 932. Nitric acid emissions coefficient from Intergovernmental Panel on Climate Change, Greenhouse Gas Inventory Reference Manual, IPCC Guidelines for National Greenhouse Gas Inventories, Vol. 3 (Paris, France, 1995), p. 2.9.

such as carpet yarn, clothing, and tire cord. Other uses of adipic acid include production of plasticizers for polyvinyl chloride and polyurethane resins, lubricants, insecticides, and dyes.

In the United States, three companies, which operate a total of four plants, manufacture adipic acid by oxidizing a ketone-alcohol mixture with nitric acid. Creation of nitrous oxide is an intrinsic byproduct of this chemical reaction. For every metric ton of adipic acid produced, 0.3 metric ton of nitrous oxide is created. ${ }^{110}$ Currently, two plants (accounting for approximately 77 percent of total production) control emissions by thermally decomposing the nitrous oxide, and 98 percent of the potential emissions from those plants are eliminated by this technique. ${ }^{111}$

In 1994, adipic acid production increased to 815,000 metric tons, resulting in increased levels of estimated nitrous oxide emissions from this source. Some of this growth may be attributed to increased demand for nylon fibers and polyvinyl chloride in 1994.

\section{Nitric Acid Production}

Nitric acid is a primary ingredient in fertilizers. The process for manufacturing this acid involves oxidizing ammonia $\left(\mathrm{NH}_{3}\right)$ with a platinum catalyst. Nitrous oxide emissions are a direct result of the oxidation. Measurements at a DuPont plant indicate emissions factors of 2 to 9 grams of nitrous oxide per kilogram of nitric acid manufactured. ${ }^{112}$

The emissions estimates presented in this report were calculated by multiplying the annual quantity of nitric acid produced by the midpoint of the emissions range determined at the DuPont plant. The 8.8 million tons of nitric acid manufactured in 1994 resulted in emissions of 48,000 metric tons of nitrous oxide. There is, however, a considerable degree of uncertainty associated with this estimate, because the emissions factor for the DuPont plant may not in fact be generalizable across the industry.

\footnotetext{
${ }^{110}$ M.H. Thiemens and W.C. Trogler, "Nylon Production: An Unknown Source of Atmospheric Nitrous Oxide," Science, Vol. 251, No. 4996 (February 1991).

${ }^{111}$ Radian Corporation, Nitrous Oxide Emissions From Adipic Acid Manufacturing (Rochester, NY, January 1992$)$, p. 10.

${ }^{112}$ R.A. Reimer, R.A. Parrett, and C.S. Slaten, "Abatement of $\mathrm{N}_{2} \mathrm{O}$ Emission Produced in Adipic Acid," in Proceedings of the Fifth International Workshop on Nitrous Oxide Emissions (Tsukuba, Japan, July 1992).
} 


\section{Halocarbons and Other Gases}

\section{Overview}

The greenhouse gases carbon dioxide, methane, and nitrous oxide are emitted in relatively large volumes. There are, in addition, several human-made greenhouse gases that are emitted in smaller volumes. Among these are chlorofluorocarbons (CFCs), hydrochlorofluorocarbons (HCFCs), bromofluorocarbons (halons), hydrofluorocarbons (HFCs), perfluorocarbons (PFCs), and other compounds. As these gases do not normally occur in nature, the atmosphere is essentially transparent to the wavelengths of infrared radiation that they absorb. Consequently, despite the relatively small volumes of their emissions, they may have relatively large effects on the heat trapping capacity of the Earth's atmosphere.

The net effects of these compounds on global climate are often uncertain. Their abilities to trap infrared radiation in the Earth's atmosphere, or their direct warming potentials, range from tens to thousands of times that of carbon dioxide. On the other hand, some of the compounds (CFCs and HCFCs) are known to deplete stratospheric ozone as a result of chemical reactions involving the chlorine atoms they contain. This leads to an indirect cooling effect, the precise size of which is unknown. ${ }^{113}$ As a result of this uncertainty and because halocarbons are regulated under the Montreal Protocol, the Intergovernmental Panel on Climate Change does not include them in their guidelines for developing national inventories. They are included in this report for completeness, with Table 33 listing the major gases covered and their global warming potentials (GWPs), principal uses, and 1990 U.S. sales and emissions estimates.

Several international agreements to control halocarbons have been signed. The Montreal Protocol (1987) committed signatories to reduce production and use of CFCs in half by 1998 and to freeze the production and use of halons by 1992. The London Amendments (1990) and Copenhagen Amendments (1992) that followed included a wider variety of halocarbons and altered the schedules for phaseouts of various compounds. All countries in the Organization for Economic Cooperation and Development have passed regulations to implement these phaseouts. In the United States, Title VI of the Clean Air Act Amendments of 1990 requires cessation of CFC production by $1996,{ }^{114}$ cessation of HCFC-22 production by 2020 , procedures to limit emissions of halocarbons during routine operation and maintenance, mandatory disposal practices, and requirements for the labeling of containers. ${ }^{115}$

In response to the elimination of CFCs, many replacement compounds are now being produced. Typically, these replacements are HCFCs and HFCs, which include hydrogen atoms to increase their reactivity. As a result, they have shorter lifetimes and are more likely to dissociate before reaching the stratosphere. The lack of chlorine in HFCs makes them unambiguously greenhouse gases, and the shorter atmospheric lifetimes of HCFCs reduce the indirect cooling effect noted for CFCs, often making these replacement compounds worse from a global climate perspective than their predecessors. The relatively nascent character of the CFC replacement industry, coupled with the wide variety of replacements, makes collection of production and sales information difficult. Consequently, emissions estimates are difficult and uncertain.

The U.S. Environmental Protection Agency (EPA) includes CFCs, halons, and several other compounds in its Toxics Release Inventory (TRI), established under the Emergency Planning and Community Right-to-Know Act of $1986 .{ }^{116}$ Facilities that process more than 25,000 pounds or use more than 10,000 pounds of a listed chemical are required to report annually on their emissions and recycling activities. Because halocarbons have many end uses, the data in the TRI represent only a portion of total emissions. Estimating emissions of

\footnotetext{
${ }^{113}$ For a discussion of the science behind the indirect effects of halocarbons on global climate, see K.P. Shine, Y. Fouquart, V. Ramaswamy, S. Solomon, and J. Srinivasan, "Radiative Forcing," in Climate Change 1994: Radiative Forcing of Climate Change (Cambridge, UK: Cambridge University Press, 1995).

${ }^{114}$ The Clean Air Act Amendments of 1990 required CFC production to cease by the end of 1994. However, in December 1993, the U.S. Environmental Protection Agency requested that DuPont extend production for an additional year to prevent undue strain on consumers.

${ }^{115}$ The Clean Air Act Amendments of 1990 (P.L. 101-549, Nov. 15, 1990), Title VI, "Stratospheric Ozone Protection," 10489AT2849-2872.

${ }^{116}$ U.S. Environmental Protection Agency, 1993 Toxics Release Inventory: Public Data Release, EPA 745-R-95-010 (Washington, DC, March 1995).
} 
Table 33. Estimated 1990 Production, Sales, and Emissions of CFCs and Other Greenhouse Gases (Thousand Metric Tons)

\begin{tabular}{|c|c|c|c|c|c|c|}
\hline Compound & $\begin{array}{c}\text { Chemical } \\
\text { Formula }\end{array}$ & $\begin{array}{c}\text { 100-Year } \\
\text { Global Warming } \\
\text { Potential } \\
\left(\mathrm{CO}_{2}=1\right)\end{array}$ & $\begin{array}{c}1990 \text { U.S. } \\
\text { Sales }\end{array}$ & $\begin{array}{c}1990 \text { or } \\
1991 \text { TRI } \\
\text { Emissions }\end{array}$ & $\begin{array}{l}\text { Estimated } \\
1990 \text { U.S. } \\
\text { Emissions } \\
\end{array}$ & Principal Uses \\
\hline \multicolumn{7}{|l|}{ Chlorofluorocarbons (CFCs) } \\
\hline Trichlorofluoromethane (CFC-11) ... & $\mathrm{CFCl}_{3}$ & 4,000 & 61.9 & 5.3 & 60 & Blowing agent, chillers \\
\hline Freon 113 (CFC-113) & $\mathrm{C}_{2} \mathrm{~F}_{3} \mathrm{Cl}_{3}$ & 5,000 & $a_{50}$ & 21.5 & 50 & Solvent \\
\hline CFC-114 $\ldots$ & $\mathrm{C}_{2} \mathrm{~F}_{4} \mathrm{Cl}_{2}$ & 9,300 & $a_{4}$ & 0.9 & 5 & Solvent \\
\hline CFC-115 & $\mathrm{C}_{2} \mathrm{~F}_{5} \mathrm{Cl}$ & 9,300 & $a_{10}$ & 0.2 & 3 & Solvent, refrigerant \\
\hline \multicolumn{7}{|l|}{ Hydrochlorofluorocarbons } \\
\hline HCFC-141b & $\mathrm{C}_{2} \mathrm{H}_{3} \mathrm{FCl}_{2}$ & 630 & NA & NA & 0.2 & CFC replacement \\
\hline Chlorodifluoroethane (HCFC-142b) .. & $\mathrm{C}_{2} \mathrm{H}_{3} \mathrm{~F}_{2} \mathrm{Cl}$ & 2,000 & $b_{<18}$ & NA & 0 & CFC replacement \\
\hline \multicolumn{7}{|l|}{ Bromofluorocarbons (Halons) } \\
\hline Halon-1211 $\ldots \ldots \ldots$ & $\mathrm{CCIF}_{2} \mathrm{Br}$ & NA & $a_{3}$ & -- & 1 & Fire extinguisher \\
\hline Halon-1301 ..... & $\mathrm{CF}_{3} \mathrm{Br}$ & 5,600 & $a_{5}$ & 0.1 & 2 & Fire extinguisher \\
\hline \multicolumn{7}{|l|}{ Hydrofluorocarbons (HFCs) } \\
\hline HFC-23. & $\mathrm{CHF}_{3}$ & 12,100 & NA & NA & 4 & CFC byproduct \\
\hline HFC-125 & $\mathrm{C}_{2} \mathrm{HF}_{5}$ & 3,200 & 0 & NA & 0 & CFC replacement \\
\hline Perfluoroethane & $\mathrm{C}_{2} \mathrm{~F}_{6}$ & 12,500 & NA & NA & 0.2 & Byproduct \\
\hline \multicolumn{7}{|l|}{ Other Chemicals } \\
\hline Carbon Tetrachloride & $\mathrm{CCl}_{4}$ & 1,400 & 229.0 & 0.7 & 30 & CFC feedstock, solvents \\
\hline Methyl Chloroform & $\mathrm{C}_{2} \mathrm{Cl}_{3} \mathrm{H}_{3}$ & 110 & 308.2 & 74.7 & 316 & Solvent \\
\hline Methylene Chloride & $\mathrm{CH}_{2} \mathrm{Cl}_{2}$ & 9 & 147.0 & 46.1 & NA & Solvent \\
\hline Chloroform ...... & $\mathrm{CHCl}_{3}$ & 5 & 196.2 & 11.0 & NA & HCFC feedstock \\
\hline Sulfur Hexafluoride . . . . . . . . . & $\mathrm{SF}_{6}$ & 24,900 & 6.0 & NA & 1 & Electrical insulator \\
\hline
\end{tabular}

NA = not available. $--=$ less than 500 metric tons.

${ }^{a}$ No 1990 data available. EIA estimate based on 1986 sales data from U.S. Environmental Protection Agency, Federal Register, Vol. 53, No. 156 (August 12, 1988).

"Based on "northern hemisphere" sales and emissions from Alternative Fluorocarbons Environmental Acceptability Study, Historic Production, Sales, and Atmospheric Release of HCFC-142b (Washington, DC, February 1994).

Sources: Chemical formulae and global warming potentials from Intergovernmental Panel on Climate Change, Climate Change 1994: Radiative Forcing of Climate (Cambridge, UK: Cambridge University Press, 1995), p. 222. Production and sales of CFCs and other chemicals from International Trade Commission, Synthetic Organic Chemicals: United States Production and Sales, 1990 (Washington, DC, 1992). TRI emissions from U.S. Environmental Protection Agency, 1992 Toxics Release Inventory: Public Data Release, EPA-745-R-94-001 (Washington, DC, April 1994). p. 73. Estimated 1990 U.S. emissions from U.S. Environmental Protection Agency, Inventory of U.S. Greenhouse Gas Emissions and Sinks, EPA230-R-94-014 (Washington, DC, September 1994), pp. 37-40. 
halocarbons is further complicated by the lack of a simple correlation between production and emissions. Major chemical companies report production and sales of $\mathrm{CFCs}$ and two HCFCs through the Alternative Fluorocarbons Environmental Acceptability Study (AFEAS). ${ }^{17}$ Although AFEAS compiles world figures, U.S. sales may sometimes be estimated on the basis of the ratio of U.S. sales to world sales. A further complication in estimating emissions is the existence of a black market in CFCs, which has developed as a result of high prices and taxes stemming from U.S. commitments to phase out the chemicals. ${ }^{118}$

Emissions of CFCs, HCFCs, and HFCs can be estimated by their end uses, which include:

- Refrigerants. The compounds are used as the working gas in refrigerators and air conditioners. Depending on the application, the chemical may leak out over a period of several years (automobile air conditioners) or remain trapped for many years (refrigerators).

- Blowing agents. The compounds are used to blow foams and insulations. They may be vented to the atmosphere immediately or trapped in the cells of the foam for long periods of time.

- Solvents or cleaning agents. In this application, the compounds may volatilize and be emitted to the atmosphere immediately. As a result of environmental and economic factors, some firms are now recycling compounds used for this purpose.

Other emissions estimates are more difficult to obtain. Halons are used in fire-fighting applications, and consequently are stored and not emitted unless there is a test, equipment failure, or fire. Some gases are used as feedstocks, meaning that emissions are incidental and far less than production figures.

Table 34 shows estimates of U.S. emissions of halocarbons. As CFCs are phased out, their estimated emissions are declining, while emissions of HCFCs and HFCs are rising rapidly. Estimated PFC emissions are declining slowly. On a GWP-weighted basis, emissions of HFCs and PFCs jumped by about 20 percent in 1994, to 24 million metric tons carbon equivalent (see Table ES2 in the Executive Summary). The procedures used to determine these estimates are described for each type of gas in the sections below. The figures are probably within 25 percent of actual (unobservable) emissions for the gases with the larger emissions, and for the period before 1992. After 1991, the phasing-in of non-CFC substitutes and the expansion of recycling programs make estimation of emissions more uncertain. Better data will probably be available in future years, as the International Trade Commission and the EPA upgrade their data collections. Production data on HCFC-141b and HFC-134a are currently being collected but have not yet been published by AFEAS.

\section{Chlorofluorocarbons (CFCs)}

CFCs are derivatives of hydrocarbons, which are composed of carbon and hydrogen atoms. In CFCs, the hydrogen atoms are replaced with chlorine and fluorine atoms, yielding an array of nontoxic, nonflammable gases useful in a wide variety of applications. CFCs have no natural source, and their high molecular stability allows them to migrate to the stratosphere, where they destroy ozone. Though molecule for molecule they absorb thousands of times more infrared radiation than carbon dioxide, their net warming affect is uncertain because of their effect on ozone. Ozone $\left(\mathrm{O}_{3}\right)$, beneficial in the stratosphere for its ability to absorb harmful ultraviolet radiation, is also a potent greenhouse gas. Thus, while the direct effect of CFCs is a warming potential far greater than that of carbon dioxide, their indirect effect on ozone leaves their effects on global climate ambiguous. ${ }^{119}$

The Copenhagen Amendments of the Montreal Protocol suggest phasing out CFCs by 1996 . The United States is implementing these provisions through the Clean Air Act Amendments of 1990 and subsequent EPA regulations, which include allowable production quotas and taxes on inventories and stocks. All production is to be stopped by January 1996.

\section{Trichlorofluoromethane (CFC-11)}

CFC-11 is principally used as a blowing agent for foams and packaging materials and as a refrigerant in large commercial chillers. Sales have been declining

\footnotetext{
${ }^{117}$ Alternative Fluorocarbons Environmental Acceptability Study, Production, Sales and Atmospheric Release of Fluorocarbons Through 1993 (Washington, DC, March 1995).

${ }^{118}$ E.A. Parson and O. Greene, "The Complex Chemistry of the International Ozone Agreements," Environment, Vol. 37, No. 2 (March 1995), p. 21.

${ }^{119}$ One study suggests that indirect cooling associated with ozone loss produces a net effect of CFCs on radiative forcing that is roughly half of their total direct effect. For more information, see K.P. Shine, Y. Fouquart, V. Ramaswamy, S. Solomon, and J. Srinivasan, "Radiative Forcing," in Climate Change 1994: Radiative Forcing of Climate Change (Cambridge, UK: Cambridge University Press, 1995$),$ p. 177.
} 
Table 34. Estimated U.S. Emissions of Halocarbons and Miscellaneous Greenhouse Gases, 1987-1994 (Thousand Metric Tons of Gas)

\begin{tabular}{|c|c|c|c|c|c|c|c|c|}
\hline Gas & 1987 & 1988 & 1989 & 1990 & 1991 & 1992 & 1993 & 1994 \\
\hline \multicolumn{9}{|l|}{ Chlorofluorocarbons (CFCs) } \\
\hline$\ldots \ldots \ldots \ldots \ldots \ldots$ & 85 & 85 & 80 & 60 & 54 & 48 & 39 & 37 \\
\hline$\ldots \ldots \ldots \ldots \ldots$ & 110 & 110 & 114 & 112 & 108 & 102 & 99 & 71 \\
\hline$\ldots \ldots \ldots \ldots \ldots \ldots$ & 83 & 83 & 78 & 50 & 39 & 28 & 20 & 17 \\
\hline Other CFCs .............. & NA & NA & NA & 9 & 9 & 9 & 8 & 8 \\
\hline $\begin{array}{l}\text { Halons } \ldots \ldots \ldots \ldots \ldots \ldots \ldots \ldots \\
\text { Hydrochlorofluorocarbons (HCFCs) }\end{array}$ & \multicolumn{5}{|c|}{ Hydrochlorofluorocarbons (HCFCs) } & & & 3 \\
\hline$\ldots \ldots \ldots \ldots \ldots$ & 68 & 74 & 76 & 82 & 82 & 86 & 89 & 105 \\
\hline Other HCFCs $\ldots \ldots \ldots \ldots \ldots$ & NA & NA & NA & 2 & 9 & 16 & 23 & 30 \\
\hline \multicolumn{9}{|l|}{ Hydrofluorocarbons (HFCs) } \\
\hline$\ldots \ldots \ldots \ldots$ & 4 & 5 & 5 & 4 & 4 & 4 & 4 & 4 \\
\hline HFC-134a & NA & NA & NA & 1 & 1 & 3 & 6 & 10 \\
\hline HFC-152a & NA & NA & NA & NA & NA & 1 & 1 & 2 \\
\hline Other HFCs & NA & NA & NA & NA & NA & NA & NA & 2 \\
\hline $\begin{array}{l}\text { Perfluorocarbons (PFCs) } \ldots \ldots \ldots \ldots \\
\text { Other Chemicals }\end{array}$ & 2 & 3 & 3 & 3 & 3 & 3 & 2 & 2 \\
\hline Carbon Tetrachloride $\ldots \ldots \ldots \ldots$ & NA & NA & NA & 30 & NA & 26 & 22 & 16 \\
\hline Methyl Chloroform $\ldots \ldots \ldots \ldots$ & 261 & 323 & 296 & 316 & 224 & 235 & 162 & 78 \\
\hline Sulfur Hexafluoride $\ldots \ldots \ldots \ldots$ & NA & NA & NA & 1 & 1 & 1 & 1 & 1 \\
\hline
\end{tabular}

NA = not available.

Sources: 1990 and 1994 emissions estimates estimates from U.S. Environmental Protection Agency, unpublished data. Other years estimated from methods described in this chapter.

steadily since 1988, with production following roughly the same trend, except for a spike in $1992 .{ }^{120}$ Based on the number of CFC-using chillers in the United States, the chiller market is probably no larger than about 10,000 metric tons. Thus, the blowing agent market is shrinking-down from about 70,000 metric tons in the mid-1980s to about 25,000 metric tons in 1993.

As restrictions on CFCs become more stringent, recycling is expected to increase. This will reduce direct emissions and extend the useful life of CFC-using equipment. The TRI reports that recycling rose from 96 metric tons in 1992 to 111 metric tons in 1993, while disposal increased from 175 metric tons to 254 metric tons. ${ }^{121}$

\section{Dichlorofluoromethane (CFC-12)}

CFC-12 is often known by its trade name, "freon-12." Exceedingly versatile, its end uses include air con- ditioning (both automotive and commercial); refrigeration (refrigerators and freezers of varying scales); and as a blowing agent for foams, insulations, and packaging. The signing of the Montreal Protocol in 1987 caused trends in its production, sales, and emissions to fluctuate. Before 1987, the production, sale, and end use of CFC-12 were all nearly equivalent. In 1988 and 1989, production and sales were well above the estimated amount of CFC-12 being incorporated in end uses, suggesting that end users were stockpiling the compound in response to the expected cessation of U.S. production. Production and sales dropped dramatically in 1990 and 1991, falling below estimates of end use applications and emissions. In recent years, the four figures have once again become consistent, with end use gradually declining as CFCs are phased out ${ }^{122}$ (Figure 7).

AFEAS data suggest that use of CFC-12 as a blowing agent decreased by nearly 90 percent between 1988 and

\footnotetext{
${ }^{120}$ U.S. International Trade Commission, Synthetic Organic Chemicals: United States Production and Sales, 1993 (Washington, DC, November 1994), p. 3-21.

${ }^{121}$ U.S. Environmental Protection Agency, 1993 Toxics Release Inventory: Public Data Release (Washington, DC, March 1995), Pp. 84-85.

${ }^{122}$ U.S. International Trade Commission, Synthetic Organic Chemicals: United States Production and Sales, 1993 (Washington, DC, November 1994), p. 3-21.
} 
Figure 7. Production, Sales, End Use, and Estimated Emissions of CFC-12, 1980-1994

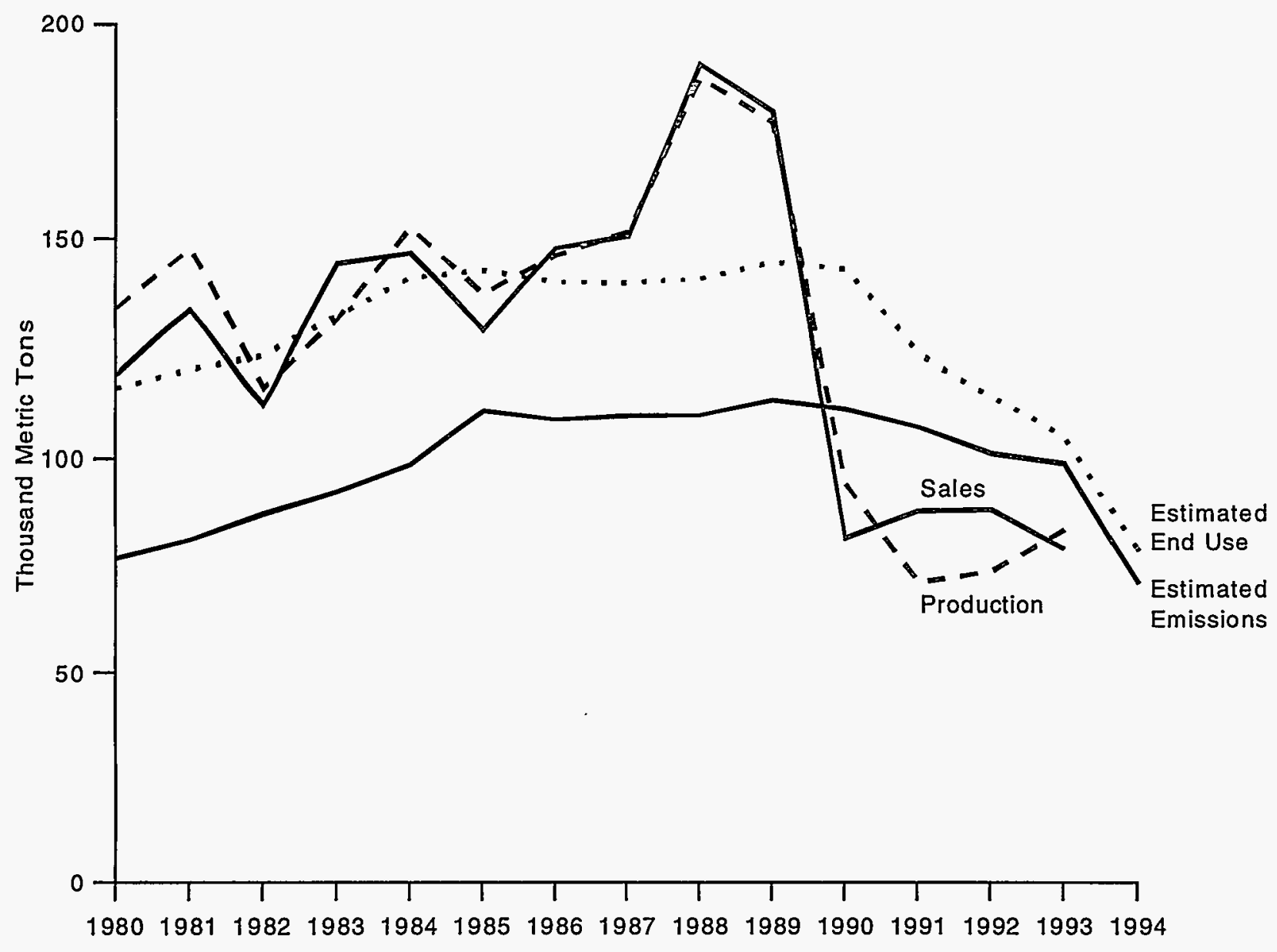

Sources: Production and Sales-International Trade Commission, Synthetic Organic Chemicals (various years). Estimated End Use and Emissions-EIA estimates based on sales of CFC-using equipment.

1993. ${ }^{123}$ While this has occurred, the stock of equipment using $\mathrm{CFC}-12$ as a refrigerant has been increasing. In recent years, however, many companies have begun to use replacements for CFC-12. Many automobile manufacturers have switched to HFC-134a as the refrigerant in new models, and several even offer services to convert older CFC-12 models to the HFC-134a versions.

Data from the TRI indicate that there was little change in recycling and disposal between 1992 and 1993. Recycling fell from 156 metric tons to 142 metric tons, with disposal remaining more constant at 40 metric tons in 1992 and 38 metric tons in 1993. ${ }^{124}$

\section{Freon 113 (CFC-113)}

CFC-113, also known as "freon 113 ," is principally used as a solvent. In particular, it is a useful cleaner for electronic circuit boards, because it volatilizes easily and will not damage the circuitry. Such an end use, and others consistent with it as detailed in AFEAS, imply that emissions of CFC-113 are roughly equivalent to production. In order to protect the confidentiality of

\footnotetext{
${ }^{123}$ Alternative Fluorocarbons Environmental Acceptability Study, Production, Sales and Atmospheric Release of Fluorocarbons Through 1993 (Washington, DC, March 1995), p. 1-10.

${ }^{124}$ U.S. Environmental Protection Agency, 1993 Toxics Release Inventory: Public Data Release (Washington, DC, March 1995), pp. 78-79.
} 
individual producers, the International Trade Commission does not disclose production and sales data for CFC-113. The last year for which sales data were available was 1986, in which sales were reported at 78,000 metric tons. ${ }^{125}$ Furthermore, the EPA estimated 1990 emissions of CFC-113 to be 50,000 metric tons. These figures, in conjunction with AFEAS data on total northern hemisphere sales, can be used to estimate U.S. sales by assuming that the ratio of U.S. sales to northern hemisphere sales remains constant. The estimates presented in Table 34 were created by using this procedure and then deducting TRI recycling and disposals.

Emissions of CFC-113 have been declining rapidly since 1988 , consistent with information contained in the TRI. In 1993, TRI emissions of CFC- 113 were about 4,500 metric tons-down substantially from the 11,000 metric tons in $1992 .{ }^{126}$ Recycling and treatment of CFC-113 have also declined in recent years, indicating that CFC-113 is being phased out in favor of alternatives.

\section{Dichlorotetrafluoroethane (CFC-114)}

CFC-114 is principally used as a solvent. According to AFEAS, roughly two-thirds of all CFC-114 sales go toward short-lifetime end uses, such as cleaning and drying agents, with the rest being used in closed-cell foams and refrigeration applications, where the compound may remain trapped for up to 12 years. ${ }^{127}$ In addition, the U.S. Department of Energy uses CFC-114 in the enrichment of uranium. Worldwide sales declined from 1986 until 1992, and 1993 sales were nearly the same as for 1992 at roughly 4,500 metric tons. ${ }^{128}$ The 1993 U.S. contribution to this amount, determined using the same procedure noted for CFC-113, was estimated at about 500 metric tons. This is also the value reported in the TRI. ${ }^{129}$

\section{Monochloropentafluoroethane (CFC-115)}

CFC-115 is used primarily as a blending agent for some specialty refrigerants. U.S. sales were last reported in 1986, when they equaled 87 percent of northern hemisphere sales reported in AFEAS. Assuming that this percentage has remained constant, U.S. sales in subsequent years can be estimated. Emissions as reported in the TRI actually increased from 1991 to 1993, from about 160 metric tons in 1991 to over 250 metric tons in $1993 .{ }^{130}$ No recycling or disposal was reported in the 1993 TRI.

\section{Hydrochlorofluorocarbons (HCFCs)}

HCFCs are essentially CFCs that include one or more hydrogen atoms. The presence of hydrogen makes the resulting compounds less stable, and as a result they are more susceptible to photodecomposition, have much shorter atmospheric lifetimes than CFCs, and consequently are less likely to migrate to the stratosphere where they would destroy ozone. As a result, they are popular interim substitutes for CFCs. The Copenhagen Amendments placed HCFCs under control, with HCFC-22 slated for elimination by 2020 and all others by 2030 .

HCFCs still have high GWPs, and these are compounded by the fact that they have weaker indirect cooling effects than do CFCs. Data are less available for HCFCs than for their relatives the CFCs. AFEAS includes information on HCFC-22 and HCFC-142b and is currently collecting information on HCFC- $141 \mathrm{~b} .{ }^{131}$ In 1996, the TRI will report 1994 emissions of 11 HCFCs, including HCFC-22, HCFC-123, HCFC-124, HCFC-141b, and HCFC-142b. ${ }^{132}$

\section{Chlorodifluoromethane (HCFC-22)}

HCFC-22 is the most commonly used refrigerant for home air conditioning systems. It is the most widely available and least expensive potential substitute for CFCs in a variety of applications. AFEAS sales information suggests that HCFC-22 use for medium-lifetime applications such as refrigeration has grown since 1988, yet has been relatively constant since $1991 .{ }^{133}$ Sales for use in other, long-lifetime applications have grown dramatically in recent years, from 1,800 metric tons in 1990 to 13,500 metric tons in 1993 . Total sales in 1993

\footnotetext{
${ }^{125}$ U.S. Environmental Protection Agency, Federal Register, Vol. 53, No. 156 (August 12, 1988).

${ }^{126}$ U.S. Environmental Protection Agency, 1993 Toxics Release Inventory: Public Data Release (Washington, DC, March 1995), pp. 80-81.

${ }^{127}$ Alternative Fluorocarbons Environmental Acceptability Study, Production, Sales and Atmospheric Release of Fluorocarbons Through 1993 (Washington, DC, March 1995), p. 2-10.

${ }^{128}$ Alternative Fluorocarbons Environmental Acceptability Study, Production, Sales and Atmospheric Release of Fluorocarbons Through 1993 (Washington, DC, March 1995), p. 2-10.

${ }^{129}$ U.S. Environmental Protection Agency, 1993 Toxics Release Inventory: Public Data Release (Washington, DC, March 1995), pp. 80-81.

${ }^{130}$ U.S. Environmental Protection Agency, 1993 Toxics Release Inventory: Public Data Release (Washington, DC, March 1995), pp. 82-83.

${ }^{131}$ Alternative Fluorocarbons Environmental Acceptability Study, Production, Sales and Atmospheric Release of Fluorocarbons Through 1993 (Washington, DC, March 1995).

${ }^{132}$ U.S. Environmental Protection Agency, 1993 Toxics Release Inventory: Public Data Release (Washington, DC, March 1995).

${ }^{133}$ Alternative Fluorocarbons Environmental Acceptability Study, Production, Sales and Atmospheric Release of Fluorocarbons Through 1993 (Washington, DC, March 1995), p. 3-8.
} 
were nearly 100,000 metric tons, down slightly from 108,000 metric tons in 1990. Production has historically exceeded sales by a substantial margin.

The emissions estimates presented in Table 34 were determined using U.S. sales data and shares of HCFC-22 for short-, medium-, and long-lifetime applications as contained in AFEAS. Sales for short-lifetime applications are assumed to represent immediate emissions, while medium- and long-lifetime applications are assumed to produce emissions over 10- and 12-year periods, respectively. This calculation indicates that total emissions have been rising, with increases in medium-lifetime application emissions explaining most of the trend. Between 1988 and 1992, emissions from short-lifetime applications rose from about 9,000 metric tons to 13,000 metric tons, returning to 9,000 metric tons in 1993. Pre-publication data from the U.S. International Trade Commission indicate that production of HCFC-22 increased substantially in 1994, implying increased usage and emissions.

\section{Chlorodifluoroethane (HCFC-142b)}

HCFC-142b is a CFC replacement with a GWP of 2,000. U.S. production and sales data are not available, and TRI data on HCFC-142b will not be available until 1996. ${ }^{134}$ AFEAS collects information on worldwide production, which taken in conjunction with information on northern hemisphere sales can be used to estimate a ceiling on U.S. sales or emissions. In 1993, worldwide production continued to grow, reaching nearly 35,000 metric tons. ${ }^{135}$ Of that amount, approximately 6,000 metric tons were sold for short-lifetime end uses, including sterilants, inhalers, and open-cell foams. ${ }^{136}$ The EPA, in a forthcoming publication, estimates 1994 emissions of HCFC-142b at 10,000 metric tons. This figure implies that much of the worldwide production of HCFC-142b may be taking place in the United States.

\section{Other HCFCs}

A number of $\mathrm{HCFCs}$ may gain importance as CFCs are phased out in the near future. HCFC-123 is a potential replacement for CFC-11 in refrigeration applications, and HCFC-124 is a potential replacement for CFC-12 in sterilizers. HCFC-141b, with a GWP of 630 , may be used as a solvent and in blends to replace CFC-11 blowing agents. Data on HCFC-141b are currently being collected by AFEAS. The EPA estimates 1994 emissions of HCFC-141b at 16,000 metric tons and 1994 emissions of HCFC-123 and HCFC-124 at 2,000 metric tons each. The EPA believes that 1990 emissions of these chemicals were negligible.

\section{Hydrofluorocarbons (HFCs)}

HFCs are hydrochlorofluorocarbons without the chlorine. Because they are composed of only carbon, hydrogen, and fluorine, they do not destroy ozone. Consequently, they are a desirable CFC replacement. Ironically, the characteristic that makes them a desirable replacement from an ozone perspective also makes them potent greenhouse gases with no offsetting indirect effects.

The market for HFCs is expanding as CFCs are being phased out. It is difficult to keep pace with the variety of HFCs that are being developed and the quantities being produced. Consequently, accurate data are difficult to obtain. As TRI and AFEAS expand their data collections, more information on the extent to which HFCs are being used as CFC replacements will become available.

\section{HFC-23}

HFC-23 is created as a byproduct in the production of HCFC-22. Small amounts are also reportedly used in semiconductor manufacture. Emissions are estimated at between 2 and 4 percent of total HCFC-22 production, implying a total of 3,000 to 5,000 metric tons per year. ${ }^{137}$ Although this total seems small, the GWP of HFC-23 is very large at 12,100 -giving it a substantial direct effect without any known offsetting indirect effects. The Climate Change Action Plan includes a voluntary program with HCFC-22 producers to reduce emissions and explore potential markets for HFC-23 as a halon replacement and refrigerant.

\footnotetext{
${ }^{134}$ The International Trade Commission collects data on HCFC-142b, but it is not disclosed, because the compound has only one U.S. producer. International Trade Commission, Synthetic Organic Chemicals 1993, USITC Publication 2810 (Washington, DC, November 1994), p. 3-21.

${ }^{135}$ Alternative Fluorocarbons Environmental Acceptability Study, Production, Sales and Atmospheric Release of Fluorocarbons Through 1993 (Washington, DC, March 1995), p. 4-6.

${ }^{136}$ Alternative Fluorocarbons Environmental Acceptability Study, Production, Sales and Atmospheric Release of Fluorocarbons Through 1993 (Washington, DC, March 1995), p. 4-8.

${ }^{137}$ U.S. Department of Energy, The Climate Change Action Plan: Technical Supplement, DOE/PO-0011 (Washington, DC, March 1994$)$, p. 67.
} 


\section{1,2,2,2-Tetrafluoroethane (HFC-134a)}

HFC-134a, with a GWP of 1,300 , is gaining importance as a replacement for CFCs, especially in automotive air conditioners. Emissions for 1990 were estimated at only 500 metric tons, but they will likely grow significantly as HFC-134a gains market share. In 1993, Ford sold nearly 40,000 vehicles that used approximately 2 pounds of HFC-134a in their air conditioners. ${ }^{138}$ Previous models used about 2.5 pounds of CFC-12. As of 1994, practically all new automobiles were using HFC-134a as the refrigerant in their air conditioners, and many manufacturers now offer conversion packages through their dealerships. Automobile air conditioners are subject to significant leakage, with nearly all of the refrigerant leaking out over a 5-year horizon. This would suggest that 1993 emissions of HFC-134a from automotive sources totaled only 15 metric tons. In 1994, however, with millions of new vehicles using HFC-134a, automotive emissions may have risen by two orders of magnitude. With increased production and usage of HFC-134a in replacement applications, emissions are expected to increase dramatically in future years. Data on HFC-134a should be available in both the TRI and AFEAS within the next year. The EPA, in a forthcoming publication, estimates 1994 emissions of HFC-134a at about 10,000 metric tons.

\section{1,1-Difluoroethane (HFC-152a)}

As a non-ozone-depleting substance with a GWP of only 140, HFC-152a is an attractive potential replacement for CFCs. It can be used as a blowing agent, an ingredient in refrigerant blends (e.g., in R-500), and in fluoropolymer manufacturing applications. It is also compatible with the components used in aerosol products. Unlike CFCs, however, HFC-152a is flammable. Only one company produces HFC-152a, and in 1995 they reported having doubled their capacity to $35 \mathrm{mil}-$ lion pounds since $1992 .^{139}$ Consequently, they probably were producing HFC-152a near full capacity in 1993. This corresponds to production of about 8,000 metric tons, which places a ceiling on emissions. The EPA estimated 1990 emissions of HFC-152a at only 300 metric tons, rising to 1,500 metric tons by 1994 . As HFC-152a gains market share forfeited by CFCs and replacements with higher GWPs, emissions are likely to increase significantly in future years.

\section{Bromofluorocarbons (Halons)}

Bromofluorocarbons are similar to CFCs except that they contain at least one bromine atom. They are inert, nontoxic, and evaporate without leaving any residue, making them popular for use as fire suppressants for high-value equipment such as computer centers and aircraft. The trade name halon is applied to several of these chemicals, which are used as fire suppressants. Halons are particularly destructive to stratospheric ozone, and consequently production will cease in 1996 as per agreements in the Montreal Protocol. The U.S. military, which uses a significant volume of halons to protect sensitive equipment, is involved in a program to reduce emissions through recycling, using substitutes, and preventing leakage of halons in existing systems. Emissions of halons are low, although the exact figure is uncertain. The TRI does not contain recycling or disposal information. The EPA estimated 1990 emissions at 1,000 metric tons apiece for halon1211 and halon-1301.

\section{Perfluorocarbons (PFCs)}

Perfluorocarbons are hydrocarbons in which the hydrogen has been replaced by fluorine. Since they contain no chlorine, they are not harmful to ozone and therefore do not possess the indirect cooling effects of CFCs. As a result, they are unambiguously greenhouse gases. The principal quantifiable source of PFCs is as a byproduct of aluminum smelting. EPA estimates that 0.6 kilogram of perfluoromethane $\left(\mathrm{CF}_{4}\right.$, also known as carbon tetrafluoride) and 0.06 kilogram of perfluoroethane $\left(\mathrm{C}_{2} \mathrm{~F}_{6}\right)$ are emitted as a result of each metric ton of aluminum smelted. ${ }^{140}$ These coefficients, in conjunction with aluminum production figures, suggest U.S. emissions of 2,200 metric tons of perfluoromethane and 220 metric tons of perfluoroethane in 1993. Perfluoromethane is also emitted during the process of uranium enrichment, at a rate that probably is less than 20 metric tons per year. ${ }^{141}$

Perfluoroethane, however, is also used as a purging agent in semiconductor manufacturing. The sole U.S. producer, DuPont, reports that it plans to double its perfluoroethane production capacity in 1995, while

\footnotetext{
${ }^{138}$ Information obtained during spoken communication with Ford representatives.

${ }_{139}^{13}$ "DuPont Set to Expand Markets for Ozone-Safe HFC-152a Product," Ozone Depletion Online Today (Alexandria, VA, June 9, 1995).

${ }^{140}$ U.S. Department of Energy, The Climate Change Action Plan: Technical Supplement, DOE/PO-0011 (Washington, DC, March 1994$)$, p. 67.

${ }^{141}$ U.S. Department of Energy, Compliance Assessment of the Portsmouth Gaseous Diffusion Plant, DOE/EH-0144 (Washington, DC, April 1990), pp. 3-20-3-21.
} 
encouraging customers to reduce their emissions by 80 percent. ${ }^{142}$ The EIA has not yet been able to ascertain DuPont's current actual capacity or production of the chemical. DuPont reports perfluoroethane production and sales to the International Trade Commission, but the data are not published, because DuPont is the sole producer. Perfluoromethane $\left(\mathrm{CF}_{4}\right)$ is also produced commercially in small quantities in Canada but not, apparently, in the United States.

PFC emissions are not regulated or reported, although their high GWPs $(6,300$ for perfluoromethane and 12,500 for perfluoroethane) have drawn the attention of the Climate Change Action Plan. As a byproduct of aluminum production, they arise during discrete periods of process inefficiency. Emissions could be reduced by improving process efficiency.

\section{Other Chemicals}

Several other chemicals combine both high GWPs and emissions levels to have a potential effect on global climate: carbon tetrachloride, methyl chloroform, chloroform, methylene chloride, and sulfur hexafluoride. Several of these chemicals are regulated under the Clean Air Act Amendments of 1990.

\section{Carbon Tetrachloride}

Carbon tetrachloride is a chemical whose uses have varied. Originally used as a household cleanser and dry-cleaning solvent, it was determined to be carcinogenic, and such uses were terminated. Most carbon tetrachloride is now used as a feedstock in the production of CFC-11 and CFC-12. Carbon tetrachloride is regulated by the Clean Air Act Amendments as a known carcinogen, and under the Montreal Protocol as an ozone-depleting chemical. Its production is to be phased out by 1996. Much like CFCs, carbon tetrachloride has a high direct GWP $(1,400)$ offset to an unknown degree by its indirect cooling effect of destroying ozone. Their net effect is likely to favor global cooling. ${ }^{143}$ Production and sales data have not been available in recent years, but output is probably declining. ${ }^{144}$ This is consistent with the phaseout of both carbon tetrachloride and the CFCs for which it is a feedstock. The TRI listed 1993 emissions of carbon tetrachloride at roughly 1,000 metric tons, up from 650 metric tons in $1992 .{ }^{145}$ The TRI suggests that about 50 metric tons were recycled in 1993, down from nearly 160 metric tons in 1993. Estimates presented in Table 34 were developed using sales data and production data for CFC-11 and CFC-12. A rough approximation of emissions is determined by calculating (on a stoichiometric basis) the portion of total carbon tetrachloride sales that goes toward production of CFCs, and assuming that the rest is used as a solvent and consequently emitted to the atmosphere.

\section{Methyl Chloroform (1,1,1-Trichloroethane)}

Like carbon tetrachloride, methyl chloroform is regulated under the Clean Air Act Amendments as an ozone-depleting chemical covered by the Montreal Protocol. It is required to be phased out by 1996 . It has indirect cooling effects akin to carbon tetrachloride and the CFCs, but its GWP is only 110. As a result, its net effect is likely to promote global cooling. ${ }^{146}$ U.S. sales of methyl chloroform continued to decline in 1993, down to 170,000 metric tons. ${ }^{147}$ U.S. sales and EPA estimates of emissions for 1990 indicate that methyl chloroform that is sold is emitted to the atmosphere shortly thereafter. Thus, estimated emissions were set equal to consumption, less the amounts reported to TRI under recycling and disposal. In 1993, recycling was reported as 7,000 metric tons, with disposals of 3,000 metric tons. ${ }^{148}$ Estimates of emissions are shown in Table 34 .

\section{Chloroform}

Chloroform is primarily used as a feedstock for HCFC-22, with secondary use as a solvent. It is a fairly weak greenhouse gas with a GWP of 5. Though no national-level emissions estimates are available, total emissions are expected to be low, because most chloroform is incorporated into HCFC-22 during its production. As chloroform is a carcinogen, it is reported to the TRI. The TRI indicates that emissions have been decreasing and were only 6,500 metric tons in $1993 .{ }^{149}$

\footnotetext{
142"DuPont Acts To Cut Perfluoroethane," Chemical Week (August 23, 1995), p. 34.

${ }^{143}$ K.P. Shine, Y. Fouquart, V. Ramaswamy, S. Solomon, and J. Srinivasan, "Radiative Forcing," in Climate Change 1994: Radiative Forcing of Climate Change (Cambridge, UK: Cambridge University Press, 1995), p. 177.

${ }^{144}$ Statistics are withheld to avoid disclosure of individual company operations. International Trade Commission, Synthetic Organic Chemicals 1993, USITC Publication 2810 (Washington, DC, November 1994), p. 3-18.

${ }^{145}$ U.S. Environmental Protection Agency, 1993 Toxics Release Inventory: Public Data Release (Washington, DC, March 1995), pp. 78-79.

${ }^{146}$ K.P. Shine, Y. Fouquart, V. Ramaswamy, S. Solomon, and J. Srinivasan, "Radiative Forcing," in Climate Change 1994: Radintive Forcing of Climate Change (Cambridge, UK: Cambridge University Press, 1995), p. 177.

${ }^{147}$ International Trade Commission, Synthetic Organic Chemicals 1993, USITC Publication 2810 (Washington, DC, November 1994), p. 3-19.

${ }^{148}$ U.S. Environmental Protection Agency, 1993 Toxics Release Inventory: Public Data Release (Washington, DC, March 1995 ), p. 85.

${ }^{149}$ U.S. Environmental Protection Agency, 1993 Toxics Release Inventory: Public Data Release (Washington, DC, March 1995$), \mathrm{p} .78$.
} 


\section{Methylene Chloride (Dichloromethane)}

Like chloroform, methylene chloride is a weak greenhouse gas (GWP of 9). Its short atmospheric lifetime of less than 1 year probably prevents it from reaching the stratosphere where it would be damaging to ozone. As a result, its indirect cooling effects are likely to be quite small. A potential carcinogen, methylene chloride emissions are regulated and included in the TRI, with 1993 emissions of 30,000 metric tons, down significantly from 46,000 metric tons in $1990 .{ }^{150}$ The TRI indicates substantial activity in recycling and disposal, with about 10,000 metric tons recycled and 6,000 metric tons undergoing disposal in 1993.

\section{Sulfur Hexafluoride}

Sulfur hexafluoride $\left(\mathrm{SF}_{6}\right)$ is used as an insulator for circuit breakers, switch gear, and other electrical equipment. In addition, its extremely low atmospheric concentration makes it a useful test gas for the calibration of gas concentration monitors. It has a high GWP of 24,900 , but it is not produced or used in large quantities. In 1989, global production and emissions were estimated at 5,000 metric tons. ${ }^{151}$ In a forthcoming report, the EPA estimates annual U.S. production of sulfur hexafluoride at 6,000 metric tons and emissions at about 1,000 metric tons annually. This is equivalent to emissions of more than 6 million metric tons of carbon.

${ }^{150}$ U.S. Environmental Protection Agency, 1993 Toxics Release Inventory: Public Data Release (Washington, DC, March 1995), pp. 80-81.

${ }^{151}$ M.K.W. Ko, N.D. Sze, W.C. Wang, G. Shia, A. Goldman, F.J. Murcray, D.G. Murcray, and C.P. Rinsland, "Atmospheric Sulfur Hexafluoride: Sources, Sinks, and Greenhouse Warming," Journal of Geophysical Research, Vol. 98, p. 10,500. 


\section{Criteria Pollutants}

\section{Overview}

The Clean Air Act of 1970 requires that air quality standards be established for pollutants that have adverse effects on public health or welfare, termed "criteria pollutants" because the U.S. Environmental Protection Agency (EPA) based each National Ambient Air Quality Standard (NAAQS) on health-based criteria from scientific studies. This report includes emissions estimates for carbon monoxide (CO), nitrogen oxides $\left(\mathrm{NO}_{\mathrm{x}}\right)$ and nonmethane volatile organic compounds (NMVOCs), which are criteria pollutants that influence the atmospheric concentrations of greenhouse gases, including carbon dioxide, methane, and ozone.

Ozone is produced largely from atmospheric chemical reactions involving these criteria pollutants. While stratospheric ozone absorbs harmful ultraviolet solar radiation, ozone in the troposphere exhibits the greenhouse properties that warm the Earth's surface. The temperature differential between the radiation absorbed by stratospheric ozone and the radiation redirected to the Earth's surface by tropospheric ozone determines the magnitude of ozone's greenhouse effect. Ozone is highly reactive with other atmospheric gases, and its concentration is influenced by meteorological conditions. As a result, it remains in the troposphere for only hours or days. Hence, concentrations of tropospheric ozone tend to be centered around cities where high levels of criteria pollutants are found. Ozone concentrations are measured at individual urban sites throughout the United States. The EPA reports that the composite average ozone concentration for its 532 U.S. testing sites has declined by 12 percent since $1984 .{ }^{152}$

The EPA Office of Air Quality Planning and Standards has compiled emissions data for the various criteria pollutants in the document National Air Pollutant Emission Trends, 1900-1993. ${ }^{153}$ The emissions estimates in this report are based on that document. The EPA continues to modify emissions data with improved estimation methods and updated information. Therefore, estimates in this report differ from those in last year's report. This year's modifications include a change in the model used to estimate emissions from highway vehicles and distinct emissions factors for California because of the unique legal and environmental conditions in that State.

Emissions of the three criteria pollutants included in this report increased slightly in 1993 (Table 35). However, emissions of both carbon monoxide and NMVOCs have declined since 1987. Emissions of nitrogen oxides have risen by approximately 4 percent over the same period.

Table 35. U.S. Emissions of Criteria Pollutants, 1987-1994

(Million Metric Tons of Gas)

\begin{tabular}{c|c|c|c|c|c|c|c|c}
\hline Source & 1987 & 1988 & 1989 & 1990 & 1991 & 1992 & 1993 & 1994 \\
\hline Carbon Monoxide ....... & 95.3 & 96.2 & 91.4 & 94.1 & 90.6 & 87.4 & 88.1 & NA \\
Nitrogen Oxides . . . . . . & 20.3 & 21.1 & 21.1 & 21.0 & 20.8 & 20.8 & 21.2 & NA \\
Nonmethane VOCs ...... & 22.1 & 22.6 & 21.5 & 22.0 & 21.3 & 20.9 & 21.1 & NA \\
\hline
\end{tabular}

$\mathrm{NA}=$ not available.

Note: Data in this table are revised from the data contained in the previous EIA report, Emissions of Greenhouse Gases in the United States 1987-1992, DOE/EIA-0573 (Washington, DC, November 1994).

Source: U.S. Environmental Protection Agency, Office of Air Quality Planning and Standards, National Air Pollutant Emission Trends, 1900-1993, EPA-454/R-94-027 (Research Triangle Park, NC, October 1994), pp. A-2-A-16.

\footnotetext{
${ }^{152}$ U.S. Environmental Protection Agency, Office of Air Quality Planning and Standards, National Air Quality and Emissions Trends Report, 1993 (Research Triangle Park, NC, October 1994), p. 43.

${ }^{153}$ U.S. Environmental Protection Agency, Office of Air Quality Planning and Standards, National Air Pollutant Emission Trends, $1900-1993$ (Research Triangle Park, NC, October 1994).
} 
The EPA predicts that emissions of criteria pollutants will decrease by the end of the decade: ${ }^{154}$

- Carbon monoxide emissions are expected to decline through 2000, with continued reductions in highway vehicle emissions expected to outweigh small increases from other sources.

- Nitrogen oxide emissions are expected to decline with the 1996 mandatory implementation of stationary source Reasonably Available Control Technology (RACT) for nitrogen oxides.

- NMVOC emissions are expected to decline as a result of RACT and other provisions of the Clean Air Act Amendments of 1990.

\section{Carbon Monoxide}

In the atmosphere, carbon monoxide is relatively shortlived, lasting only 2 to 3 months before being oxidized into carbon dioxide. Carbon monoxide also functions as the primary sink for atmospheric hydroxyl radicals $\left(\mathrm{OH}^{-}\right)$. Through the process of oxidation, hydroxyl radicals chemically break apart methane molecules. Therefore, by reducing the concentration of hydroxyl radicals, carbon monoxide indirectly increases the amount of methane in the atmosphere. In the presence of nitrogen oxides, carbon monoxide also plays a role in the production of tropospheric ozone.

Most carbon monoxide is produced from incomplete combustion of fuels. Transportation sources account for most of the carbon monoxide: consistently 75 to 80 percent of total emissions (Table 36). In 1993, 88 million metric tons of carbon monoxide were emitted to the atmosphere, representing an overall decline of 16 percent from 1980 levels. This reduction can be attributed to pollution controls and replacement of older, less fuelefficient vehicles.

\section{Nitrogen Oxides}

The molecules $\mathrm{NO}$ and $\mathrm{NO}_{2}$ are commonly referred to as nitrogen oxides. These gases are important for their role as catalysts in the chemical reactions that create tropospheric ozone. Nitrogen oxides may also reduce stratospheric ozone if they are emitted directly from aircraft at high altitudes.

Fossil fuel combustion is the main point of origin for nitrogen oxide emissions, particularly from electric power generation and transportation sources. In addition, the chemical industry produces a minor amount of noncombustion emissions, included under "Industrial Processes" in Table 37. Nitrogen oxide emissions in 1993 totaled 21 million metric tons. Since 1980, this figure has remained relatively stable.

\section{Nonmethane Volatile Organic Compounds}

A "volatile" organic compound is one that plays an active role in atmospheric photochemical reactions. NMVOCs include such gases as propane, butane, and ethane, as well as many more complex chemicals. NMVOCs affect climate change in two ways: first, as with carbon monoxide, they may indirectly increase atmospheric methane concentrations through reduction of hydroxyl; second, they lead to production of tropospheric ozone.

In 1993, NMVOC emissions were estimated at 21 million metric tons (Table 38 ). This is an overall reduction of 10 percent from 1980 levels. Industrial processes continue to be the primary source of NMVOC emissions, due in part to solvent use. Emissions from highway vehicles have declined by approximately 32 percent since 1980 as a result of tailpipe emissions controls mandated by the Clean Air Act. 
Table 36. U.S. Carbon Monoxide Emissions, 1987-1994

(Million Metric Tons)

\begin{tabular}{|c|c|c|c|c|c|c|c|c|}
\hline Source & 1987 & 1988 & 1989 & 1990 & 1991 & 1992 & 1993 & 1994 \\
\hline \multicolumn{9}{|l|}{ Transportation } \\
\hline Highway Vehicles & 64.08 & 64.47 & 59.91 & 57.01 & 56.30 & 54.29 & 54.41 & NA \\
\hline Aircraft & 0.80 & 0.84 & 0.87 & 0.88 & 0.87 & 0.89 & 0.92 & NA \\
\hline Railroads & 0.10 & 0.11 & 0.11 & 0.11 & 0.11 & 0.11 & 0.11 & NA \\
\hline Vessels & 0.05 & 0.05 & 0.05 & 0.05 & 0.05 & 0.05 & 0.06 & NA \\
\hline Other Off-Highway & 11.87 & 12.15 & 12.14 & 12.24 & 12.23 & 12.46 & 12.76 & NA \\
\hline Total $\ldots \ldots \ldots \ldots$ & 76.89 & 77.62 & 73.08 & 70.29 & 69.56 & 67.81 & 68.26 & NA \\
\hline \multicolumn{9}{|l|}{ Stationary Source Fuel Combustion } \\
\hline Electric Utilities . . . . . . . . . . . & 0.27 & 0.28 & 0.29 & 0.28 & 0.28 & 0.28 & 0.29 & NA \\
\hline Industrial $\ldots \ldots \ldots \ldots \ldots$ & 0.59 & 0.61 & 0.61 & 0.61 & 0.62 & 0.61 & 0.60 & NA \\
\hline Commercial-Institutional & 0.07 & 0.07 & 0.07 & 0.07 & 0.07 & 0.07 & 0.08 & NA \\
\hline Residential ........... & 5.63 & 5.47 & 5.27 & 5.07 & 4.94 & 4.44 & 3.91 & NA \\
\hline Total $\ldots \ldots \ldots \ldots \ldots \ldots \ldots$ & 6.56 & 6.44 & 6.24 & 6.05 & 5.92 & 5.41 & 4.88 & NA \\
\hline Total Energy-Related Emissions ... & 83.45 & 84.06 & 79.31 & 76.34 & 75.48 & 73.22 & 73.14 & NA \\
\hline Industrial Processes $\ldots \ldots \ldots \ldots \ldots$ & 4.54 & 4.74 & 4.78 & 4.74 & 4.67 & 4.71 & 4.79 & NA \\
\hline Incineration $\ldots . .$. & 0.83 & 0.82 & 0.79 & 0.77 & 0.75 & 0.78 & 0.79 & NA \\
\hline Open Burning $\ldots \ldots \ldots \ldots$ & 0.84 & 0.82 & 0.79 & 0.76 & 0.74 & 0.77 & 0.78 & NA \\
\hline $\begin{array}{c}\text { Total } \ldots \ldots \ldots \ldots \ldots \ldots \\
\text { Miscellaneous }\end{array}$ & 1.68 & 1.64 & 1.58 & 1.53 & 1.49 & 1.56 & 1.57 & NA \\
\hline Forest Fires & 1.07 & 1.07 & 1.07 & 6.83 & 4.35 & 3.25 & 3.98 & NA \\
\hline Other Burning ....... & 4.56 & 4.67 & 4.64 & 4.62 & 4.56 & 4.63 & 4.64 & NA \\
\hline Total ........... & 5.63 & 5.74 & 5.71 & 11.45 & 8.91 & 7.87 & 8.62 & NA \\
\hline Total All Sources & 95.29 & 96.18 & 91.38 & 94.06 & 90.56 & 87.36 & 88.12 & NA \\
\hline Carbon Content of Carbon Monoxide . . & 40.84 & 41.22 & 39.16 & 40.31 & 38.81 & 37.44 & 37.77 & NA \\
\hline $\begin{array}{l}\text { Carbon Content of Energy-Related } \\
\text { Carbon Monoxide } \ldots \ldots \ldots \ldots \ldots \ldots \ldots\end{array}$ & 35.77 & 36.03 & 34.00 & 32.72 & 32.36 & 31.39 & 31.35 & NA \\
\hline
\end{tabular}

$N A=$ not available.

Note: Data in this table are revised from the data contained in the previous EIA report, Emissions of Greenhouse Gases in the United States 1987-1992, DOE/EIA-0573 (Washington, DC, November 1994).

Source: U.S. Environmental Protection Agency, Office of Air Quality Planning and Standards, National Air Pollutant Emission Trends, 1900-1993, EPA-454/R-94-027 (Research Triangle Park, NC, October 1994), Table A-1, pp. A-2-A-5. 
Table 37. U.S. Nitrogen Oxide Emissions, 1987-1994

(Million Metric Tons)

\begin{tabular}{|c|c|c|c|c|c|c|c|c|}
\hline Source & 1987 & 1988 & 1989 & 1990 & 1991 & 1992 & 1993 & 1994 \\
\hline \multicolumn{9}{|l|}{ Transportation } \\
\hline Highway Vehicles $\ldots \ldots \ldots \ldots \ldots$ & 6.95 & 6.95 & 6.97 & 6.79 & 6.69 & 6.75 & 6.75 & NA \\
\hline Aircraft $\ldots \ldots \ldots \ldots \ldots \ldots \ldots$ & 0.12 & 0.12 & 0.13 & 0.13 & 0.13 & 0.13 & 0.13 & NA \\
\hline$\ldots \ldots \ldots \ldots \ldots \ldots$ & 0.77 & 0.81 & 0.84 & 0.84 & 0.84 & 0.86 & 0.86 & NA \\
\hline Vessels $\ldots \ldots \ldots \ldots \ldots \ldots \ldots$ & 0.14 & 0.15 & 0.16 & 0.16 & 0.16 & 0.16 & 0.17 & NA \\
\hline Other Off-Highway $\ldots \ldots \ldots \ldots \ldots$ & 1.39 & 1.56 & 1.46 & 1.45 & 1.41 & 1.47 & 1.55 & NA \\
\hline Total $\ldots \ldots \ldots \ldots \ldots \ldots \ldots \ldots$ & 9.37 & 9.59 & 9.55 & 9.37 & 9.22 & 9.36 & 9.45 & NA \\
\hline \multicolumn{9}{|l|}{ Stationary Source Fuel Combustion } \\
\hline Electric Utilities . . . . . & 6.47 & 6.83 & 6.90 & 6.82 & 6.79 & 6.78 & 7.06 & NA \\
\hline Industrial . & 2.78 & 2.89 & 2.91 & 2.95 & 3.00 & 2.91 & 2.88 & NA \\
\hline Commercial-Institutional & 0.27 & 0.28 & 0.27 & 0.27 & 0.28 & 0.28 & 0.28 & NA \\
\hline Residential . . . . . . . . & 0.36 & 0.38 & 0.38 & 0.38 & 0.39 & 0.38 & 0.37 & NA \\
\hline Total $\ldots \ldots \ldots \ldots \ldots \ldots \ldots \ldots$ & 9.88 & 10.38 & 10.46 & 10.42 & 10.45 & 10.34 & 10.59 & NA \\
\hline Total Energy-Related Emissions . . . & 19.24 & 19.97 & 20.01 & 19.79 & 19.68 & 19.71 & 20.05 & NA \\
\hline Industrial Processes $\ldots \ldots \ldots \ldots \ldots$ & 0.79 & 0.82 & 0.81 & 0.81 & 0.80 & 0.81 & 0.83 & NA \\
\hline \multicolumn{9}{|l|}{ Solid Waste Disposal } \\
\hline Incineration & 0.03 & 0.03 & 0.03 & 0.03 & 0.03 & 0.03 & 0.03 & NA \\
\hline Open Burning . & 0.05 & 0.05 & 0.05 & 0.05 & 0.04 & 0.05 & 0.05 & NA \\
\hline Total $\ldots \ldots \ldots \ldots \ldots \ldots \ldots \ldots$ & 0.08 & 0.08 & 0.08 & 0.07 & 0.07 & 0.08 & 0.08 & NA \\
\hline \multicolumn{9}{|l|}{ Miscellaneous } \\
\hline Forest Fires . & - & - & - & • & - & * & * & NA \\
\hline Other Burning & 0.18 & 0.19 & 0.19 & 0.35 & 0.28 & 0.25 & 0.27 & NA \\
\hline Total ......... & 0.18 & 0.19 & 0.19 & 0.35 & 0.28 & 0.25 & 0.27 & NA \\
\hline Total All Sources .. & 20.30 & 21.05 & 21.08 & 21.02 & 20.83 & 20.84 & 21.22 & NA \\
\hline
\end{tabular}

*Less than 5,000 metric tons.

$\mathrm{NA}=$ not available.

Note: Data in this table are revised from the data contained in the previous EIA report, Emissions of Greenhouse Gases in the United States 1987-1992, DOE/EIA-0573 (Washington, DC, November 1994).

Source: U.S. Environmental Protection Agency, Office of Air Quality Planning and Standards, National Air Pollutant Emission

Trends 1900-1993, EPA-454/R-94-027 (Research Triangle Park, NC, October 1994), Tables A-2, pp. A-6-A-9. 
Table 38. U.S. Emissions of Nonmethane Volatile Organic Compounds, 1987-1994 (Million Metric Tons)

\begin{tabular}{|c|c|c|c|c|c|c|c|c|}
\hline Source & 1987 & 1988 & 1989 & 1990 & 1991 & 1992 & 1993 & 1994 \\
\hline \multicolumn{9}{|l|}{ Transportation } \\
\hline Highway Vehicles .............. & 7.44 & 7.52 & 6.52 & 6.22 & 5.89 & 5.51 & 5.53 & NA \\
\hline Aircraft $\ldots \ldots \ldots \ldots \ldots \ldots \ldots \ldots$ & 0.16 & 0.17 & 0.17 & 0.17 & 0.17 & 0.18 & 0.18 & NA \\
\hline Railroads $\ldots \ldots \ldots \ldots \ldots$. & 0.04 & 0.04 & 0.04 & 0.04 & 0.04 & 0.04 & 0.04 & NA \\
\hline$\ldots \ldots \ldots \ldots \ldots$ & 0.03 & 0.03 & 0.04 & 0.04 & 0.04 & 0.04 & 0.04 & NA \\
\hline Other Off-Highway $\ldots \ldots \ldots \ldots \ldots$ & 1.62 & 1.67 & 1.66 & 1.67 & 1.68 & 1.71 & 1.74 & NA \\
\hline Total $\ldots \ldots \ldots \ldots \ldots \ldots \ldots \ldots$ & 9.29 & 9.43 & 8.43 & 8.14 & 7.82 & 7.47 & 7.53 & NA \\
\hline \multicolumn{9}{|l|}{ Stationary Source Fuel Combustion } \\
\hline Electric Utilities & 0.03 & 0.03 & 0.03 & 0.03 & 0.03 & 0.03 & 0.03 & NA \\
\hline Industrial & 0.23 & 0.25 & 0.24 & 0.24 & 0.24 & 0.25 & 0.25 & NA \\
\hline Commercial-Institutional & 0.01 & 0.01 & 0.01 & 0.01 & 0.01 & 0.01 & 0.01 & NA \\
\hline Residential . . . . . . . . & 0.42 & 0.41 & 0.40 & 0.38 & 0.37 & 0.33 & 0.29 & NA \\
\hline Total $\ldots \ldots \ldots \ldots \ldots \ldots \ldots$ & 0.69 & 0.70 & 0.68 & 0.66 & 0.66 & 0.62 & 0.58 & NA \\
\hline Total Energy-Related Emissions . . . & 9.98 & 10.13 & 9.11 & 8.80 & 8.48 & 8.09 & 8.11 & NA \\
\hline Industrial Processes $\ldots \ldots \ldots \ldots \ldots$ & 9.65 & 10.00 & 9.92 & 9.96 & 9.98 & 10.02 & 10.16 & NA \\
\hline \multicolumn{9}{|l|}{ Solid Waste Disposal } \\
\hline Incineration $\ldots$. & 0.06 & 0.05 & 0.05 & 0.05 & 0.05 & 0.05 & 0.05 & NA \\
\hline Open Burning $\ldots \ldots \ldots \ldots$ & 0.26 & 0.26 & 0.25 & 0.24 & 0.23 & 0.24 & 0.24 & NA \\
\hline Other $\ldots \ldots \ldots \ldots \ldots \ldots \ldots \ldots$ & 1.73 & 1.78 & 1.78 & 1.76 & 1.73 & 1.76 & 1.76 & NA \\
\hline Total $\ldots \ldots \ldots \ldots \ldots \ldots$ & 2.05 & 2.10 & 2.08 & 2.05 & 2.01 & 2.06 & 2.06 & NA \\
\hline \multicolumn{9}{|l|}{ Miscellaneous } \\
\hline Forest Fires & 0.15 & 0.15 & 0.15 & 0.94 & 0.60 & 0.44 & 0.55 & NA \\
\hline Other Burning . & 0.25 & 0.27 & 0.26 & 0.26 & 0.25 & 0.26 & 0.26 & NA \\
\hline Total $\ldots \ldots \ldots$ & 0.40 & 0.42 & 0.41 & 1.20 & 0.85 & 0.71 & 0.81 & NA \\
\hline Total All Sources $\ldots \ldots \ldots \ldots \ldots$. . . . & 22.07 & 22.64 & 21.52 & 22.01 & 21.32 & 20.88 & 21.14 & NA \\
\hline
\end{tabular}

NA = not available.

Notes: Data in this table are revised from the data contained in the previous EIA report, Emissions of Greenhouse Gases in the United States 1987-1992, DOE/EIA-0573 (Washington, DC, November 1994). Assumes a carbon coefficient of 0.83 metric tons of carbon per metric ton of NMVOC. Totals may not equal sum of components due to independent rounding.

Source: U.S. Environmental Protection Agency, Office of Air Quality Planning and Standards, National Air Pollutant Emission Trends 1900-1993, EPA-454/R-94-027 (Research Triangle Park, NC, October 1994), Table A-3, pp. A-10-A-16. 


\section{Land Use Issues}

\section{Overview}

This chapter describes some of the ways in which different types of land use affect emissions and sequestration of greenhouse gases and provides estimates of the scale of such emissions and sequestration. From a global warming perspective, the most important land use issues are those related to forest creation and destruction. Forests and forest soils remove and store large amounts of carbon from the atmosphere. In contrast, temperate-zone land-use-related emissions of methane and nitrous oxide are relatively small and contribute only minimally to global climate change. Because of these differences, more discussion in this chapter is devoted to forestland use than other types of land use.

Emissions of carbon dioxide from the combustion of fossil fuels are dwarfed by carbon dioxide emissions and absorption from natural processes. As noted in Chapter 1, natural processes in the oceans and biomass are responsible for most carbon dioxide absorption and emissions. This is also true of methane and nitrous oxide. Most methane and nitrous oxide are created by bacteria in soils and wetlands. Although the most important natural processes affecting greenhouse gas concentrations in the atmosphere are not subject to human control, modifications in land use can influence their concentrations in significant ways.

The magnitude of the influence is difficult to measure. Unlike service station pumps, trees and swamps do not come equipped with meters. Thus, analysts can only estimate emissions or sequestration on the basis of small sample surveys and extrapolate (with associated uncertainty) to much larger regions. A second, related problem is distinguishing between human-caused and natural phenomena. An electric power plant is clearly a human artifact. Trees growing back over abandoned farmland are a more ambiguous case.

To avoid confusion with other definitions in this report, land use is defined in this chapter to include only forestland, cropland, grassland, pasture and range, wetlands, and impervious surface areas such as urban areas, roads, and highways. Use and disposal of materials derived from these areas is not included, except in the case of wood products.

\section{Land Use and the Carbon Budget}

As noted in the Executive Summary of this report, of the trace gases, carbon dioxide is the largest single contributor to global warming, responsible for 85 percent of U.S. global warming potential (GWP)-weighted emissions of greenhouse gases. Thus, from a global warming perspective, the most important modifications in land use are those that significantly affect the carbon budget.

The most important changes in land use are those that increase or reduce forestland. U.S. forests removed a net 123 million metric tons of carbon in 1990, including the net 12 million metric tons sequestered in wood products and the net 15 million metric tons sequestered in landfilled wood product waste. ${ }^{155}$ This quantity would offset approximately 9 percent of the $1,430 \mathrm{mil}-$ lion metric tons of carbon emitted by the United States in 1994 from the burning of fossil fuels (see Chapter 2).

In contrast, cropland, grassland, and pasture and range, once established, do not significantly affect greenhouse gas concentrations until they are changed to another land use. The carbon flux in cropland, grassland, and pasture and range is close to zero when considered over periods of a year or more at a time, not including the initial high carbon losses that are typical during the first few years after conversion. Carbon lost when plants are harvested or grazed or die back during the winter is normally recaptured the following year in new growth, resulting in no significant net change in the carbon budget. ${ }^{156}$ Such land does release nitrous oxide and methane to the atmosphere, but these gases are relatively unimportant contributors to U.S. GWPweighted emissions of greenhouse gases, totaling only

\footnotetext{
${ }^{155}$ R.A. Birdsey and L.S. Heath, "Carbon Changes in U.S. Forests," in L.A. Joyce (ed.), Productivity of America's Forests and Climate Change (Fort Collins, CO: USDA Forest Service, in press, 1995).

${ }^{156}$ W.H. Schlesinger, "Changes in Soil Carbon Storage and Associated Properties with Disturbance and Recovery," in J.R. Trabalka and D.E. Riechle (eds.), The Changing Carbon Cycle: A Global Analysis (New York, NY: Springer-Verlag, 1986 ), p. 199.
} 
13 percent in 1993 (the total share attributable to land uses is even less). Impervious surfaces, such as roads and large percentages of urban areas, once established, halt the process of carbon sequestration and emission entirely by preventing growth of vegetation and entombing soil carbon, thereby removing it from the cycle.

\section{Carbon Cycling in Forests}

Of the land uses discussed in this chapter, changes in total forest area have the most important impact on U.S. anthropogenic contributions to greenhouse gas emissions. Forests sequester atmospheric carbon in biomass and soil. As noted above, on average all U.S. forests combined, and the wood products they produce, sequestered a net 123 million metric tons of carbon in 1994.

The mechanism driving forest carbon cycling is photosynthesis. Every green plant is, in effect, a solarpowered factory that extracts carbon dioxide from the atmosphere, separates the carbon atom from the oxygen atoms, returns oxygen to the atmosphere, and uses the carbon to make biomass in the form of roots, stems, and foliage. A fraction of dead vegetation accumulates as soil, and large quantities of roots annually die and slough off, sequestering additional carbon in the ground.

The opposite of photosynthesis is respiration, the release of carbon to the atmosphere as carbon is used for energy within plants. Trees add new cell layers each year. Old and new cells require energy for maintenance. Growth and increased maintenance cause respiration to increase. Eventually, because of limitations to total foliage area, the rate of photosynthesis cannot keep pace with respiration, and trees enter a stage of rough equilibrium between photosynthesis and respiration. Often they become net carbon emitters. Because trees must continually grow in diameter in order to survive, the imbalance leads to mortality, and the cycle shifts into reverse as a portion of the carbon is released through decay.

Accretion of carbon in living biomass is only one aspect of forest carbon sequestration. Leaf litter, fallen trees and branches, and other decaying biomass all add carbon to the soil as they decompose, even though most carbon is released to the atmosphere. More importantly, a large amount of carbon is added underground to the soil as roots die and slough off. The older a forest becomes without major perturbations (such as intense fires or conversion to cropland), the more carbon is stored in the soil. An estimate by Richard Birdsey of the U.S. Forest Service places the percentage of carbon in mature forests stored in the soil at 59 percent-only 31 percent is stored in live roots, stems, branches, and foliage. About 9 percent of all carbon is stored in litter, humus, and coarse woody debris on the forest floor, and about 1 percent is found in understory vegetation. The estimated amount of carbon stored in the soil is 42 metric tons per acre, with a total of 30 billion metric tons stored in the soils of all U.S. forests. ${ }^{157}$ In contrast, agricultural fields can contain 10 or fewer metric tons of carbon per acre. ${ }^{158}$

Even without the gradual sequestration of carbon in the soil, the current inventory of biomass in the form of forests and natural vegetation contains enormous amounts of carbon. Birdsey's study estimated that U.S. forest ecosystems contained 52.5 billion metric tons of carbon in 1987-the equivalent of nearly 40 years of U.S. carbon emissions from fossil fuel consumption.

In the tropics, the continuing destruction of forests is releasing large volumes of carbon dioxide into the atmosphere. In the United States, however, the process is stable or moving slightly in reverse. Many forests in North America, especially in the East, were cleared for farming during the 19th century. As eastern farms have been abandoned for more productive lands in the Midwest, much of the land has reverted to forests that will continue to grow for decades to come. In addition, more than 4 million acres of marginal cropland have been reforested since 1974 under such Federal programs as the Conservation Reserve Program, Agricultural Conservation Program, and Forestry Incentives Program. ${ }^{159}$

As noted above, U.S. forests and wood products absorbed an estimated net 123 million metric tons of carbon in 1990, equivalent to about 9 percent of energyrelated carbon emissions in 1994. An estimate made in a report by the U.S. Environmental Protection Agency (EPA), placed net absorption from forested areas in the coterminous United States at 114 million metric tons for the year $1990 .{ }^{160}$ That report also estimated total carbon storage in U.S. forestland at 38.5 billion metric tons,

\footnotetext{
${ }^{157}$ R.A. Birdsey, Carbon Storage and Accumulation in United States Forest Ecosystems, U.S. Forest Service General Technical Report WO-59 (Washington, DC, 1992), p. 3.

${ }^{158}$ R.N. Sampson and S.M. Winnett, "Trees, Forests, and Carbon" in Forests and Global Change, Vol. 1 (Washington, DC, 1992$)$, p. 44.

${ }^{159}$ F.C. Cubbage, "Federal Land Conversion Programs," in Forests and Global Change, Vol. 1 (Washington, DC, 1992$)$, p. 184.

${ }^{160}$ U.S. Environmental Protection Agency, The Forest Sector Carbon Budget of the United States: Carbon Pools and Flux Under Alternative Policy Options, EPA/600/3-93/093 (Washington, DC, May 1993), p. xiii.
} 
14 billion metric tons less than Birdsey's estimate, which illustrates some of the uncertainties associated with calculations of this sort. Birdsey estimated that U.S. forests absorbed 460 million metric tons of carbon between 1982 and 1987-equivalent to an annual growth rate in sequestered carbon of 0.8 percent.

While trees on existing acreage continue to absorb carbon, the acreage planted in forests can also expand or contract. Farm and pastureland can be converted to forestland, and forestland can be cleared and converted to other uses. Clearing forestland sets the stage for large-scale losses of carbon to the atmosphere, while allowing crop or pastureland to grow trees sets the stage for large-scale absorption of carbon.

Other types of land use conversion produce more ambiguous results. In general, converting pastureland or grassland into cropland typically produces emissions of carbon through the destruction of biomass and loss of soil carbon through tillage and crop harvest. Typical estimates of the amount of soil carbon lost are approximately 30 percent of the amount in place at the time of conversion. ${ }^{161}$ These losses can be expected to take place over a period of 20 years, or longer, following conversion. Similarly, abandoning cropland or converting it to forest normally leads to net carbon sequestra- tion through the creation and long-term growth of biomass and corresponding additions to soil carbon.

Table 39 shows U.S. Department of Agriculture (USDA) estimates of the major uses of land in the United States, developed through a periodic sample survey. The survey is conducted every 5 years, most recently for the year 1992. The USDA has not yet published all the 1992 survey results: in particular, the publication that gives the comprehensive view of land use, Major Uses of Land in the United States, has not yet been published. However, draft estimates for the basic information contained in Table 39 were obtained, and published material indicates that between 1987 and 1992 there was a net increase of 6 million acres of forestland. ${ }^{162}$

Between 1982 and 1992 there was a large net reduction in the amount of active cropland. The amount of land used for crops declined by 45 million acres, while the amount of idle cropland increased by 35 million acres. The total amount of non-Federal rural cropland (excluding Alaska) declined by 24 million acres. ${ }^{163}$ While the total amount of cropland declined, the amount of idle cropland increased by 1 million acres. There were much smaller declines in private pastureland and rangeland (1.6 million acres and 3.7 million acres, respectively). The shift from cultivated to idle cropland-or shifts

Table 39. Major Uses of Land in the United States (Million Acres)

\begin{tabular}{|c|c|c|c|c|}
\hline Land Use & 1978 & 1982 & 1987 & 1992 \\
\hline$\ldots \ldots \ldots$ & 471 & 469 & 464 & 461 \\
\hline Used for Crops . . . . . . . . . . . & 369 & 383 & 331 & 338 \\
\hline Idle Cropland $\ldots \ldots \ldots \ldots \ldots$ & 26 & 21 & 68 & 56 \\
\hline Pasture $\ldots \ldots \ldots \ldots \ldots \ldots$ & 76 & 65 & 65 & 67 \\
\hline Grassland Pasture and Range . . . . . & 587 & 597 & 591 & 591 \\
\hline Forest-Use Land $\ldots \ldots \ldots \ldots \ldots$ & 737 & 721 & 731 & 737 \\
\hline Grazed Land $\ldots \ldots \ldots \ldots \ldots \ldots$ & 172 & 158 & 155 & 145 \\
\hline Special Use $\ldots \ldots \ldots \ldots \ldots \ldots$ & 34 & 66 & 83 & 89 \\
\hline Other Use $\ldots \ldots \ldots \ldots \ldots \ldots$ & 531 & 497 & 493 & 503 \\
\hline Special Use Areas $\ldots . \ldots \ldots \ldots$ & 124 & 204 & 196 & 281 \\
\hline Miscellaneous Other Land . . . . . . . & 345 & 274 & 283 & 283 \\
\hline Total Land Area......... & 2,264 & 2,265 & 2,265 & 2,263 \\
\hline
\end{tabular}

Sources: A. Daugherty, Major Uses of Land in the United States: 1987, Economic Research Service Report 643 (Washington, DC: U.S. Department of Agriculture, January 1991), p. 4; and A. Daugherty, Major Uses of Land in the United States: 1992, unpublished review draft (1995).

${ }^{161}$ Soils initially very low in carbon tend to gain slight amounts of carbon after cultivation, but richer soils tend to lose at least 20 percent of their carbon after cultivation begins. See L.K. Mann, "Changes in Soil Carbon Storage After Cultivation," Soil Science, Vol. 142, No. 5 (November 1986), p. 279; and W.H. Schlesinger, "Changes in Soil Carbon Storage and Associated Properties with Disturbance and Recovery," in J. Trabalka and D. Riechle (eds.), The Changing Carbon Cycle: A Global Analysis (New York: Springer-Verlag, 1986), p. 212.

${ }^{162}$ The reported 10-million-acre increase in forestlands during 1982-1987 was due to a reclassification of existing land, rather than to a change in land use. See A. Daugherty, U.S. Department of Agriculture, Economic Research Service, Major Uses of Land in the United States: 1987, Agricultural Economic Report Number 643 (Washington, DC, January 1991), p. iii.

${ }^{163}$ U.S. Department of Agriculture, Soil Conservation Service, Summary Report: 1992 National Resources Inventory (Washington, DC, July 1994), p. 4. 
from cropland to range or pasture-should, in principle, lead to small increases in net carbon storage. Shifts from any of the above to urban land should lead to stable or slightly reduced storage.

It is difficult to be specific about how much carbon might be gained or lost through transformations of grasslands, pasturelands, or croplands. Although the amount of carbon in a square meter of forest might be on the order of 9 to 26 kilograms, depending on the condition of the forest and the age and type of trees growing, typical estimates of carbon storage in cultivated lands range from 1 to 8 kilograms per square meter, and estimates for uncultivated (but cultivatable) lands range from 2 to 10 kilograms per square meter. ${ }^{164}$ Thus, there is less carbon to be gained or lost, and the range of possible outcomes per unit of land is consequently smaller.

A recent study commissioned by the EPA estimated a current average soil carbon content for an area of 272 million acres of farmland in the United States at 4.8 to 7.9 kilograms per square meter. ${ }^{165}$ The study estimated that 1.0 billion to 1.6 billion metric tons of soil carbon had been lost from the farmland since it had been placed in cultivation, equivalent to 16 percent of the estimated original carbon content of the soil. The study also noted, however, that land with a soil carbon content of less than 4 kilograms per square meter was generally not being cultivated at the time of the study.

It would not be surprising if the least fertile farmland were the most likely to be removed from cultivation. Therefore, assuming that no trees are planted or naturally regenerate, the carbon gains from idling cropland are likely to be small: if the gains were commensurate with the original losses, they would be on the order of 0.6 kilograms per square meter (2.6 metric tons per acre), accrued over 20 to 50 years. However, the small gain would be distributed over a large acreage, since, as noted above, some 45 million acres were withdrawn from cultivation between 1982 and 1987. This implies eventual carbon storage of nearly 114 million metric tons, accrued at a rate of 2 million to 5 million metric tons per year. An estimate made for the year 1980 suggests that carbon sequestration from the abandonment of croplands in the United States and Canada was 3 million metric tons. ${ }^{166}$ These estimates would be considerably higher if all idled cropland had been afforested.
Converting land to forest should produce carbon gains, both through the addition of biomass (i.e., carbon stored in trees) and through the accretion of carbon into the soil, as dead limbs, trees, and roots gradually decay above and below ground. On average, the amount of carbon stored in U.S. forests is 17.7 kilograms per square meter of forestland (using the Birdsey/USDA estimate for storage), or 13 kilograms per square meter (using the EPA estimate). The range in forest storage across States is very large: from 9 kilograms per square meter in Nevada to 26 kilograms per square meter in Alaska, according to Birdsey.

As a crude numerical example, converting former cropland to forest might sequester approximately 10 kilograms per square meter over a 70-year period. (The actual amount would depend on the soil fertility and original carbon content of the land, the type of trees planted, and other factors specific to a particular plot of land.) This would produce 40.5 metric tons per acre over a 70-year period, or an average of 0.58 metric tons per acre per year. If the actual characteristics of the 6 million acres converted over the past 5 years matched this example, the conversion would ultimately store about 220 million metric tons of carbon over the next 70 years, at an average rate of 3.5 million metric tons per year. The actual annual rate could vary considerably from the average, since some species of trees grow much more rapidly in their early years than do others.

The examples above highlight two methodological problems common to adding carbon sources and sinks derived from land use data to more conventional greenhouse gas emissions:

- Distinguishing Between Anthropogenic and Biogenic Activities. Human beings plant trees, but trees also reproduce themselves. In general, biomass grows to the capacity limits of the ecosystem, given enough time. It is therefore difficult to determine which activities are biogenic and which are anthropogenic when both activities occur in tandem. If humans plant forests and protect them as they grow, that is in principle an anthropogenic activity. Humans also abandon farmland, however, and trees can grow back by themselves, without human intervention.

\footnotetext{
${ }^{164}$ See the scattergram in L.K. Mann, "Changes in Soil Carbon Storage After Cultivation," Soil Science, Vol. 142, No. 5 (November 1986), p. 284.

${ }^{165}$ ManTech Environmental Technology, Inc., Impact of Conservation Tillage on Soil and Atmospheric Carbon in the Contiguous United States, PB92-113448, prepared for the Corvallis Environmental Research Laboratory, U.S. Environmental Protection Agency (September 1991), p. 7.

${ }^{166}$ R.A. Houghton et al., "The Flux of Carbon from Terrestrial Ecosystems to the Atmosphere in 1980 Due to Changes in Land Use: Geographic Distribution of the Global Flux," Tellus, Vol. 39 (1987), p. 124.
} 
There are parts of the United States (some areas in national parks, or parts of the interior of Alaska, for example) that remain close to an undisturbed state and continue to add biomass without human intervention. It is less clear that this carbon sequestration should "count" as anthropogenic. The broadest definition of anthropogenic would take the view that because humans control all land use in the United States, all land use decisions, whether of omission or commission, are anthropogenic acts. This argument might lead to the conclusion that by not cutting down and burning all its forests, the United States has saved 50 billion metric tons of carbon emissions in each year in which the forests were not cut down. Alternatively, too narrow a definition of anthropogenic could exclude unambiguous reforestation activities. There is no single universally acceptable definition of anthropogenic for the purpose of making an emissions inventory, and any decision that is made will inevitably be arbitrary to some degree.

- Assigning Anthropogenic Emissions and Sinks to a Particular Calendar Year. After a tree is planted, it can grow and sequester carbon for many years. The period during which a tree grows to its full height varies from a few decades for the fastergrowing species to more than a century for slowergrowing species. Thus, trees planted in 1990 will absorb some amount of carbon dioxide from the atmosphere every year for decades to come. Similarly, surviving trees planted in 1950 are still absorbing carbon dioxide from the atmosphere today. Unfortunately, the future carbon-absorbing properties of current tree planting depend on the preservation of the forest through time. Thus, attributing all of the carbon sequestration of the next 100 years to a tree planted today is to bet on a century of continued intent and luck, and creates an opportunity for misstating the long-run sequestration potential of timberland that is repeatedly harvested. Alternatively, accurately estimating carbon sequestration today or in the future requires an understanding and accounting of changes in land use made in the past.

\section{Methane Emissions from Wetlands}

As discussed in Chapter 1, there are numerous natural sources of methane. Anthropogenic land use changes inevitably affect those natural sources. One such natural source is wetlands. However, the stock of natural wetlands in the United States has diminished considerably over the past 2 centuries, which should, in principle, have reduced biogenic methane emissions. A recent study of wetland losses concluded that the United States had lost approximately 30 percent of its wetlands between colonial times and the mid-1980s. Almost all of this loss has occurred in the lower 48 States, which have lost 53 percent of their original wetlands. ${ }^{167}$ Ten States-Arkansas, California, Connecticut, Illinois, Indiana, Iowa, Kentucky, Maryland, Missouri, and Ohio-have lost 70 percent or more of their original wetland acreage. Nationally, remaining wetlands totaled approximately 274 million acres in 1985; wetlands lost totaled 119 million acres by the mid-1980s.

An update of the wetlands study indicates that 654,000 acres were converted from wetlands to other uses between 1982 and 1987, and that an additional 431,000 acres were converted between 1987 and $1991 .{ }^{168}$ Extrapolating from these data, it is estimated that wetlands in the United States are currently destroyed at a rate of approximately 86,000 acres per year. It is difficult to find information on the conversion of other land categories to wetlands. It is assumed that the number and extent of wetland creations is small enough to leave the above loss estimates essentially unchanged.

The range of observed methane fluxes from U.S. wetlands is enormous. One survey of experiments conducted in the United States found estimates ranging from a negative flux (methane absorption) to a flux of 213 grams of methane per square meter per year, largely dependent on habitat type. ${ }^{169}$ Thus, it is difficult to extrapolate from experimental data to large-scale emissions estimates.

Estimates of global methane fluxes from wetlands tend to indicate that methane emissions from temperate-zone wetlands are minimal-typically between 5 and 10 million metric tons of methane per year for worldwide

${ }^{167}$ T. Dahl, U.S. Department of the Interior, Fish and Wildlife Service, Wetlands Losses in the United States: 1780's to 1980's (Washington, DC, 1990).

${ }_{168}^{16 . S .}$. Department of Agriculture, Soil Conservation Service, 1991 Update of National Resources Inventory Wetlands Data for Non-Federal Rural Lands (Washington, DC, not dated), p. 4.

${ }^{169} \mathrm{~K}$. Bartlett and R.C. Harriss, "Review and Assessment of Methane Emissions from Wetlands," Chemosphere, Vol. 26, Nos. 1-4 (1993), pp. 272-276. 
temperate-zone wetlands (which include U.S. wetlands)-when compared with estimated global wetlands emissions of 110 million metric tons. ${ }^{170}$ The U.S. share of all temperate-zone wetlands is about 57 percent, and temperate-zone wetlands lost during the 1980 s accounted for about 0.5 percent of U.S. wetlands at the beginning of the period. Consequently, the reduction in natural methane emissions from wetlands lost might be on the order of $0.57 \times 0.005 \times 5$ to $10 \mathrm{mil}-$ lion metric tons of methane, or from 10,000 to 20,000 metric tons of methane annually over the decade.

\section{Land Use Modiffication of Methane Sinks}

The scientific literature suggests that grasslands and forestlands are both weak natural sinks for methane and weak natural sources for nitrous oxide. Natural soils apparently serve as methane sinks: well-aerated soils contain a class of bacteria called "methanotrophs," which use methane as food and oxidize it into carbon dioxide. Experiments indicate that cultivation reduces methane uptake by soils and increases nitrous oxide emissions. ${ }^{171}$

Exactly how much methane is absorbed by natural soils, and how much nitrous oxide is emitted, is more difficult to estimate, although total amounts are very small. One report, based on experimental data, indicates that methane uptake in temperate evergreen and deciduous forests in the United States ranges from 0.19 to 3.17 milligrams (measured in carbon units) per square meter per day, equivalent to the uptake of 36.8 to 624.4 metric tons of methane per million acres per year. ${ }^{172}$ Thus (assuming no methane uptake at all from previous use), adding 6 million acres of forestland from 1987 to 1992 should increase methane absorption by 221 to 3,746 metric tons per year. Using the same numbers, all forestland in the United States may remove from 27,122 to 460,183 metric tons of methane per year. Comparing this figure with U.S. anthropogenic methane emissions of about 27 million metric tons per year, as estimated in this report, indicates that the magnitude of methane uptake by natural soils is not great.
Another report in the scientific literature indicates that some sample plots of pastureland in the United States have methane uptake rates of 4.1 milligrams (measured in carbon units) per square meter per day (for fertilized pasture) and 6.3 milligrams per square meter per day (for unfertilized pasture), with uptake from fertilized wheat and maize fields ranging from 0.2 to 0.9 milligrams per square meter. ${ }^{173}$ This study implies that an additional 0.6 to 6.1 milligrams of methane per square meter per day would be absorbed by abandoned farmland, equivalent to 118.1 to 1,201.1 grams per acre per year. Applying these figures to the 35 million acres of cropland taken out of production between 1982 and 1992 implies an increase in methane uptake of 4,133 to 42,038 metric tons per year from this source.

If such estimates are to be applied to emissions inventories, the same problem of crediting the uptakes applies. Removing an acre of farmland from production in a particular year creates a permanent annual methane sink that will absorb small additional amounts of methane each year thereafter, or at least until the use of the land changes. The method that should be used to credit such permanent reductions to a particular year is not obvious.

\section{Nitrous Oxide Emissions from Land Use Changes}

Nitrous oxide, while a highly potent greenhouse gas molecule-for-molecule compared to carbon dioxide, is released to the atmosphere from anthropogenic and natural sources in the United States in such trace amounts that its contribution to global warming is minimal. As noted in the Executive Summary, emissions of nitrous oxide were only 2 percent of U.S. GWP-weighted emissions in 1993. Of those emissions, it is difficult to say what percentage resulted from land uses, primarily due to the wide range of estimates concerning the magnitude of nitrous oxide emissions from nitrogen fertilizer use (which in any case should be included in agriculture statistics instead of land use statistics-see Chapter 4), and the lack of research data on nitrous oxide emissions from forest and grassland soils.

\footnotetext{
${ }^{170}$ See E. Matthews and I. Fung, "Methane Emissions from Natural Wetlands: Global Distribution, Area, and Environmental Characteristics," Global Biogeochemical Cycles, Vol. 1, No. 1 (March 1987); and K. Bartlett and R.C. Harriss, "Review and Assessment of Methane Emissions from Wetlands," Chemosphere, Vol. 26, Nos. 1-4 (1993), p. 280.

${ }^{171}$ See A. Mosier et al., "Methane and Nitrous Oxide Fluxes in Native, Fertilized, and Cultivated Grasslands," Nature, Vol. 350 , No. 6316 (March 28, 1991), pp. 330-332.

${ }^{172}$ P.A. Steudler et al., "Influence of Nitrogen Fertilization on Methane Uptake in Temperate Forest Soils," Nature, Vol. 341 (September 28, 1989), pp. 314-315.

${ }^{173}$ A. Mosier and D. Schimel, "Influence of Agricultural Nitrogen on Atmospheric Methane and Nitrous Oxide," Chemistry \& Industry, Vol. 2 (December 1991), p. 875.
} 
It is known that conversion of forests and grasslands to cropland accelerates nitrogen cycling and increases nitrous oxide emissions from the soil. It is not known with certainty by how much. ${ }^{174}$ Some estimates have been made of the difference between fertilized and unfertilized soils. The same research paper that described methane uptake in fertilized and unfertilized plots also described changes in nitrous oxide emissions from fertilized soils. ${ }^{175}$ (The mechanism by which this occurs is discussed in Chapter 4.) That paper indicated that unfertilized soils had emissions of 0.25 to 0.35 milligrams (measured in nitrogen units) per square meter per day, while emissions from fertilized soils ranged from 0.6 to 1.65 milligrams per square meter per day. Thus, abandoning fertilization should reduce nitrous oxide emissions by 0.35 to 1.3 milligrams per square meter per day-the equivalent of 86 to 321 metric tons of nitrous oxide per million acres per year. Applying this figure to the 35 million acres of cropland taken out of production between 1982 and 1992 implies a reduction in nitrous oxide emissions ranging from 3,010 to 11,235 metric tons annually. In principle, however, about three-quarters of the reduction in emissions from this source should be captured by reduced application of nitrogen fertilizers; thus, reporting emissions reductions using this method would result in significant double counting of units already included in the agriculture statistics in Chapter 4.

\footnotetext{
${ }^{174}$ See A. Mosier, "Nitrous Oxide Emissions From Agricultural Soils," paper presented at RIVM International Workshop on Methane and Nitrous Oxide: Methods in National Emission Inventories and Options for Control (Amersfoort, The Netherlands, February 3-5, 1993).

${ }^{175}$ A. Mosier and D. Schimel, "Influence of Agricultural Nitrogen on Atmospheric Methane and Nitrous Oxide," Chemistry E Industry, Vol. 2 (December 1991), p. 875.
} 


•




\section{Appendix A \\ Carbon Coefficients Used in This Report}

\section{Overview}

In preparing last year's edition of Emissions of Greenhouse Gases in the United States, the Energy Information Administration (EIA) developed new emissions coefficients for estimating carbon released from the combustion of fossil fuels in the United States. The EIA developed annualized emissions coefficients for coal, by rank, using 5,426 samples in EIA's coal analysis file. Coefficients for pipeline-quality and flared natural gas were calculated, based on 6,743 gas samples drawn from the U:S. gas distribution system. More than 20 petroleum products were assigned emissions coefficients based on their density, heat content, and carbon share, as revealed by product samples or underlying chemical composition. For a more detailed discussion of the methods employed in the development of these coefficients, please refer to Appendix A of last year's report. ${ }^{176}$

Emissions coefficients specific for the United States were developed as an alternative to the more general coefficients recommended by the Intergovernmental Panel on Climate Change (IPCC). ${ }^{177}$ The IPCC coefficients are intended to be suitable for all nations, and to be used in conjunction with consumption data for various end-use products, as defined by the International Energy Agency (IEA). Using U.S. specific emissions coefficients allows EIA to capture the specific characteristics of fuel consumed in the United States, while taking advantage of the more detailed breakdown of product consumption in U.S. energy statistics.

With the exception of revised coefficients for jet fuel and liquefied petroleum gas (LPG), the emissions coefficients developed for last year's report were adopted for this year's edition. The emissions coefficient for LPG was also annualized, as were the coefficients for motor gasoline and crude oil. The composition of all petroleum products varies over time, as a result of economic changes (e.g., increases in the price of oil), regulatory changes (e.g., the Clean Air Act), or changes in refining technology. By annualizing or, in the absence of yearly data, periodically updating emissions coefficients, this variation is reflected, and the precision of carbon emissions estimates is increased. The new annual coefficients are listed in Table A1.

This Appendix describes the derivation of the revised and annualized emissions coefficients applied in this year's report. It also offers a brief discussion of the difficulties of defining a "typical" still gas and, thus, assigning an accurate emissions coefficient.

\section{Motor Gasoline and Motor Gasoline Blending Components}

Motor gasoline consumption is the largest single source of anthropogenic greenhouse gas emissions in the United States, releasing nearly 270 million metric tons of carbon in 1993. As with all petroleum products, the principal determinants of an emissions coefficient for motor gasoline are its density and carbon content. Density of motor gasoline varies systematically between summer and winter grades of gasoline, and from low octane to high octane. Over the past decade, the density of all octane grades, across all seasons, has been increasing slowly. Table A2 shows that density has increased by as much as 3.5 degrees API (depending on season and octane) over the past 10 years, raising emissions coefficients over that period from 19.38 million metric tons per quadrillion Btu to 19.43 million metric tons per quadrillion Btu.

The trend toward increased density in motor gasoline can be traced, in part, to the gradual elimination of leaded gasoline. In 1984, more than 40 percent of all gasoline supplied was leaded; by 1991, the last year for which data on leaded gasoline production were collected, that share had fallen to 2 percent. As Table A2 shows, leaded gasoline was the least dense of all gasoline grades.

\footnotetext{
${ }^{176}$ Energy Information Administration, Emissions of Greenhouse Gases in the United States 1987-1992, DOE/EIA-0573 (Washington, DC, November 1994), pp. 73-92.

${ }^{177 I n t e r g o v e r n m e n t a l ~ P a n e l ~ o n ~ C l i m a t e ~ C h a n g e, ~ G r e e n h o u s e ~ G a s ~ I n v e n t o r y ~ R e f e r e n c e ~ M a n u a l, ~ I P C C ~ G u i d e l i n e s ~ f o r ~ N a t i o n a l ~ G r e e n h o u s e ~}$ Gas Inventories, Vol. 3 (Paris, France, 1995), pp. 1.10-1.29.
} 
Table A1. Carbon Emissions Coefficients at Full Combustion, 1984-1994

(Million Metric Tons of Carbon per Quadrillion Btu)

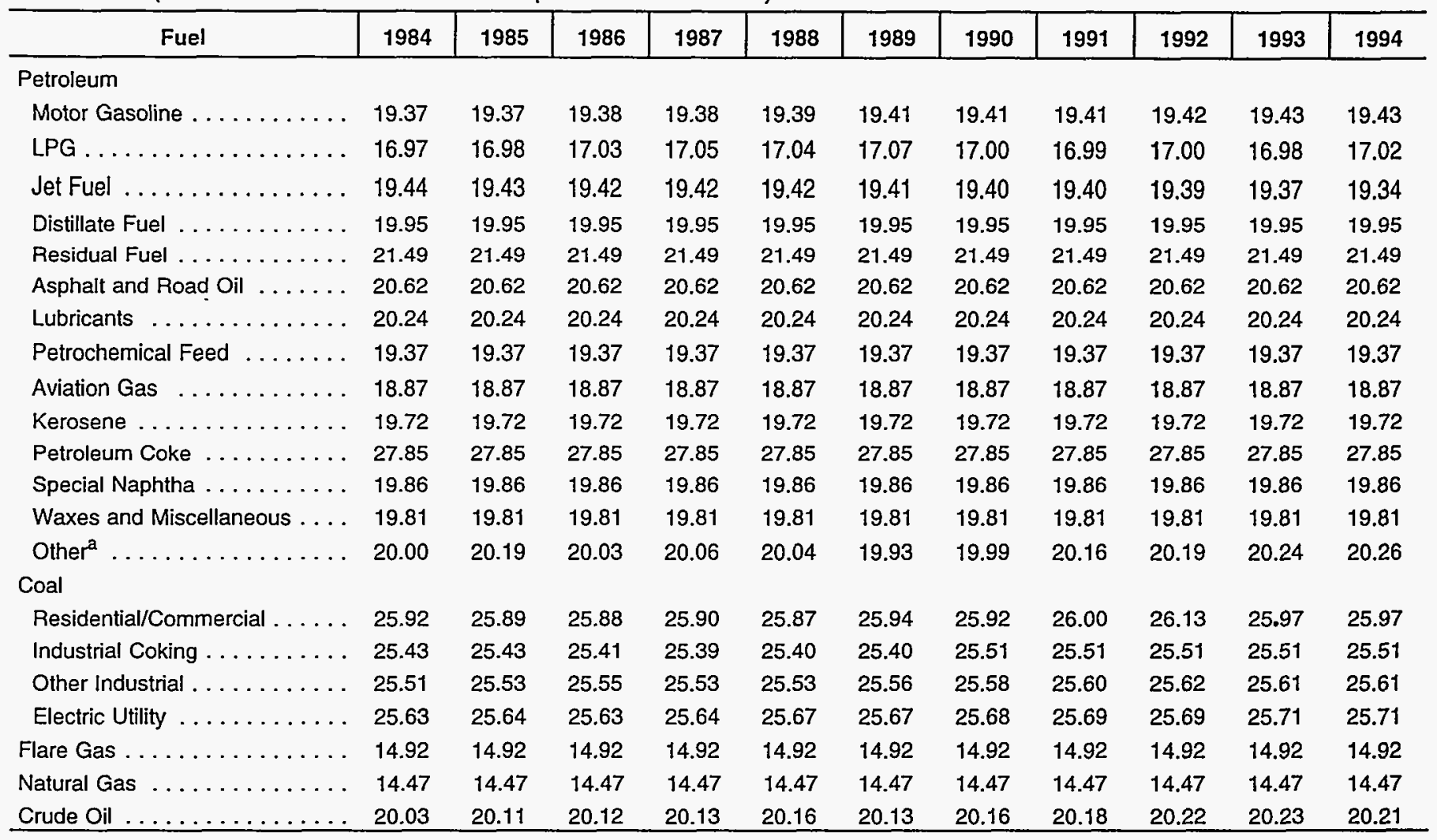

${ }^{a}$ Composite coefficient based on final calculations, accounting for fraction not combusted and deductions for nonfuel use, using unpublished disaggregated energy data.

Source: Energy Information Administration, Emissions of Greenhouse Gases in the United States 1987-1992, DOE/EIA-0573 (Washington, DC, November 1994), pp. 78-92, and estimates presented in this appendix.

Table A2. Trends in Motor Gasoline Density, All Grades, 1984-1994 (Degrees API)

\begin{tabular}{|c|c|c|c|c|c|c|c|c|c|c|c|}
\hline Fuel Grade & 1984 & 1985 & 1986 & 1987 & 1988 & 1989 & 1990 & 1991 & 1992 & 1993 & 1994 \\
\hline Leaded & 63.4 & 63.3 & 62.9 & 62.6 & 62.2 & 62.0 & 62.0 & " & * & * & NA \\
\hline Mid Octane & * & * & * & * & $\star$ & 59.9 & 60.8 & 60.4 & 60.2 & 59.9 & NA \\
\hline High Octane. & 60.1 & 59.7 & 59.7 & 60.3 & 59.6 & 58.8 & 59.0 & 59.3 & 59.0 & 58.7 & NA \\
\hline \multicolumn{12}{|l|}{ Summer Grade } \\
\hline Low Octane ...... & 59.4 & 59.3 & 59.5 & 59.2 & 58.9 & 58.2 & 58.2 & 58.0 & 57.4 & 56.1 & NA \\
\hline Mid Octane & * & * & * & $*$ & * & 57.1 & 57.4 & 57.1 & 56.4 & 55.5 & NA \\
\hline High Octane & 57.9 & 57.5 & 57.0 & 57.1 & 56.8 & 55.3 & 55.5 & 55.7 & 55.6 & 54.4 & NA \\
\hline $\begin{array}{l}\text { Average Emissions Coefficient } \\
\text { (Million Metric Tons Carbon }\end{array}$ & & & & & & & & & & & \\
\hline
\end{tabular}

$\mathrm{NA}=$ not available.

* Data prior to 1989 do not include mid-grade octane. Data after 1990 do not include leaded gasoline.

aWinter grade densities are the average of winter months, including the end of one calendar year and the beginning of the next calendar year. Source: National Institute of Petroleum and Energy Research, Motor Gasoline, Summer, and Motor Gasoline, Winter (1984-1994). 


\section{Oxygenated and Reformulated Gasoline}

Carbon coefficients in upcoming years are likely to be affected by environmental regulation requiring the addition of blending components during certain times of the year and/or in certain areas of the country. The Clean Air Act Amendments of 1990 mandated the addition of oxygenated blends to gasoline beginning in November 1992 and reformulated blends beginning in 1995 for heavily polluted areas. Oxygenated mixtures reduce carbon monoxide emissions by increasing the oxygen content of gasoline, while reformulated mixtures limit aromatic content, consequently reducing hydrocarbon emissions. Oxygenated and reformulated gasoline are initially mandated only in pollution nonattainment areas during the winter months. Various studies suggest that factors such as limited pump space and industry competition may push the supply of the new blends to anywhere from 25 percent of total market sales to 100 percent by the end of the decade. ${ }^{*}$ Data on oxygenated gasoline are just becoming available, and data on reformulated gasoline should appear some time during 1996. The effect of Clean Air Act mandates on carbon emissions coefficients will depend largely on how pervasive the new blends become outside nonattainment areas, and to what extent consumption patterns change in response to the availability of the new fuels.**

Changes in carbon content due to the addition of oxygenated blending components may be negligible, but the effect of reformulated gasoline appears more significant. According to DeLuchi, the carbon content of reformulated fuels may be as low as 83.3 percent. The impact of the reduction in carbon content on an overall emissions coefficient is somewhat moderated by a simultaneous reduction in energy content caused by the blending of reformulated gasoline. Thus, while each gallon of gasoline may have less carbon, more gallons must be consumed to achieve the same level of vehicle miles traveled.

\footnotetext{
*R. Salthouse, Making Clean Gasoline (Logistics Management Institute, September 1992); and A.K. Rhodes, "U.S. Refiners Scramble To Meet Reformulated Gasoline Mandate," Oil and Gas Journal (January 27, 1992).

${ }^{* *}$. Dale et al., "First Oxygenated Gasoline Season Shakes Out Differently Than Expected," Oil and Gas Journal (October 25, 1993).
}

In order to create unleaded gasoline with the same octane rating and "anti-knock" quality as leaded gasoline, refiners must synthesize additional volumes of light aromatic hydrocarbons and blend them into paraffinic straight-run naphtha. Aromatic hydrocarbons have a much higher ratio of carbon to hydrogen than do other typical hydrocarbons. Because carbon is more dense than hydrogen, aromatics drive up the density of unleaded gasoline. Further, the increased ratio of carbon to hydrogen in aromatics also drives up the carbon share. The result is higher emissions coefficients. Unleaded premium gasoline achieves its higher octane rating with an even larger share of aromatics, and hence has higher density and carbon content than regular unleaded gasoline.

After density, the percentage of carbon in motor gasoline is the most important determinant of its carbon emissions coefficient. While the density of commercially supplied gasoline may vary by as much as 10 degrees API, the share of carbon in gasoline is unlikely to vary by more than plus or minus 2 percent. Carbon share is bounded by the ratios of carbon to hydrogen in the hydrocarbon compounds that compose gasoline. Thus, the uncertainty associated with estimating carbon content is limited.

The carbon contents used to develop emissions coefficients for this report are based on a study conducted by Mark DeLuchi. ${ }^{178}$ Using ultimate analyses of motor gasoline samples taken during 1981, DeLuchi estimated carbon contents of 87.1 percent for summer gasoline and 86.2 percent for winter gasoline. He also provided an estimate of 86.6 percent for the average carbon content for all grades of gasoline, based on samples taken during 1981, 1985, 1987, 1989, and 1990. The 86.6 percent average was adopted for this analysis, because the multi-year sample is more likely to incorporate the changing composition of gasoline.

To estimate annualized emissions coefficients for motor gasoline, data on density by season and octane grade

\footnotetext{
${ }^{178}$ M. DeLuchi, Emissions of Greenhouse Gases From the Use of Transportation Fuels and Electricity, Vol. 2, ANL/ESD/TM-22 (Chicago, IL: Argonne National Laboratory, November 1993), Appendix C, pp. C-1-C-8.
} 
were obtained from the National Institute of Petroleum and Energy Research (NIPER). ${ }^{179}$ These data were used in conjunction with the carbon share of 86.6 percent to develop an emissions coefficient for each grade of octane in each season. The coefficients were then weighted by the share of annual consumption each grade represents, to derive an annual emissions coefficient. Although gasoline grades are typically divided into only two seasons, winter and summer, each annual emissions coefficient represents a combination of three seasonal sets of coefficients: a winter season (January, February, and March), a summer season (April through September), and a second winter season (October, November, and December). The first and second set of winter coefficients used for each year may differ slightly due to variations in the density of motor gasoline over time, as reported to NIPER. For this report, it was assumed that "motor gas blending components" are identical to motor gasoline in their average composition and hence have the same emissions coefficients.

\section{Jet̂ Fuel}

EIA energy statistics distinguish between two types of jet fuel: "naphtha-based" and "kerosene-based." Naphtha-based jet fuels, used primarily by the military, represented about 10 percent of jet fuel consumption in 1993 but less than 3 percent in 1994. This rapid decline is believed to be the result of the Defense Department's conversion from naphtha-based JP-4 jet fuel to kerosene-based JP-8 jet fuel. Because of the diminishing importance of naphtha-based jet fuel, no additional work on its emissions coefficient was undertaken, and the factor developed for last year's report (19.95 million metric tons per quadrillion Btu) was retained.

Kerosene-based jet fuels include civil-grade Jet $A$, consumed by commercial jet airliners. Combustion of kerosene-based jet fuel is an important contributor to U.S. greenhouse gas emissions, accounting for emissions of 58 million metric tons of carbon in the United States during 1993. The emissions coefficient for kerosene-based jet fuel was revised from last year's report after additional data on the density and carbon share of commercially sold jet fuels were obtained. For last year's report, the density of Jet A was estimated at
42 degrees API and the carbon share at 86.3 percent. The density estimate was based on 38 fuel samples examined by NIPER. ${ }^{180}$ Carbon share was estimated on the basis of a hydrogen content of 13.6 percent found in fuel samples taken in 1959 and reported by Martel and Angello, ${ }^{181}$ and an assumed sulfur content of 0.1 percent.

Boeing, the leading commercial airline supplier in the United States, conducts its own tests of jet fuel properties, to ensure the safe and efficient operation of the airplanes it sells. Using data from 39 samples of Jet A analyzed by Boeing, the ELA now estimates the average density of Jet A at 44.5 degrees API and the average carbon share at 85.8 percent. ${ }^{182}$ Although the NLPER density data and the Boeing data are from contemporaneous samples, it is likely that the Boeing data are more representative of fuel being consumed by the commercial fleet. Because the work done by Martel and Angello used samples dating from 1959 to 1972 and the Boeing work used samples from 1989, the carbon share estimated from the Boeing data is presumed to be more reliable. A lower density is consistent with a slightly reduced carbon share, further supporting the use of the Boeing data for both density and carbon share.

The carbon emissions coefficient resulting from these density and carbon estimates may appear surprisingly low at 19.33 million metric tons per quadrillion Btu, down from 19.71 a year ago. This is a result of the continued use of EIA's heat content estimate of 5.67 million Btu per barrel for kerosene-based jet fuel. Because the estimated density of the fuel has decreased, the heat content (Btu per pound) has been artificially raised, reducing the overall emissions coefficient. If the heat content is estimated directly from product samples, the coefficient rises to 19.56 million metric tons per quadrillion Btu. In order to maintain consistency with EIA energy data, however, EIA's standard heat content was used.

For convenience of use, the coefficients for naphthabased jet fuel and kerosene-based jet fuel were combined into a single coefficient. An annualized jet fuel coefficient was derived by weighting the two coefficients by consumption share. Annual coefficients range from a high of 19.42 million metric tons per quadrillion Btu in 1984 to a low of 19.34 in 1994 (Table A1).

\footnotetext{
${ }^{179}$ National Institute of Petroleum and Energy Research, Motor Gasoline, Summer, and Motor Gasoline, Winter (1984-1994).

${ }^{180}$ C. Dickson, Aviation Turbine Fuels, 1992, NIPER-179 PPS93/2 (Bartlesville, OK: National Institute for Petroleum and Energy Research, March 1993).

${ }^{181}$ C.R. Martel and L.C. Angello, "Hydrogen Content as a Measure of the Combustion Performance of Hydrocarbon Fuels," in Current Research in Petroleum Fuels, Vol. 1 (New York, NY: MSS Information Corporation, 1977), p. 116.

${ }^{182}$ O.J. Hadaller and A.M. Momenthy, The Characteristics of Future Fuels, Part 1, "Conventional Jet Fuels" (Seattle, WA: Boeing Corp., September 1990), pp. 46-50.
} 


\section{Crude Oil}

Crude oil is rarely consumed directly in the United States, representing less than 0.1 percent of U.S. oil consumption. This report estimates emissions based on end-use consumption, limiting the importance of a crude oil coefficient. However, if emissions are estimated using a mass balance approach, the emissions coefficient for crude oil accounts for most of the carbon - emissions from petroleum.

For last year's report, the EIA developed a regression equation for predicting the share of carbon in crude oil from its density and sulfur content. Density and sulfur content are used as measures of commercial value; thus, data for these independent variables are readily available. Using ultimate analyses of 182 crude oil samples, the following equation was developed:

$$
\begin{aligned}
\text { Percent Carbon }= & 76.99+(10.19 \times \text { Specific Gravity }) \\
& +(-0.76 \times \text { Sulfur Content }) .
\end{aligned}
$$

Previously, a density of 31 degrees API and a sulfur content of 1 percent were adopted as representative of an "average" barrel of crude oil. However, the EIA collects and publishes annually a weighted average density and sulfur content for crude oil input at refineries. ${ }^{183}$ These data were assembled for the period 1980 through 1994 and entered into the regression equation outlined above. The result was a series of annual carbon shares for crude oil. When used in conjunction with the density data and EIA's standard heat content for crude oil of 5.8 million Btu per barrel, they produce annualized emissions coefficients that rise steadily from 19.94 million metric tons in 1980 to 20.23 in 1993, before dropping back slightly to 20.21 in 1994 (Table A1). The increase can be attributed directly to the increase in density of crude oil entering refineries. Crude oil density moved from 33.76 degrees API to 31.30 degrees API between 1980 and 1993.

\section{Liquefied Petroleum Gas}

LPG consists of light hydrocarbons extracted from natural gas and sold to end users. The ELA collects data on four categories of paraffinic hydrocarbons under the heading LPG: ethane, propane, isobutane, and $n$-butane. Each category represents a discrete, pure paraffinic compound. ${ }^{184}$ In last year's report, pentanes-plus, a fuel category including hydrocarbons with more than five carbon atoms, was erroneously included in the calculation of an emissions coefficient for LPG. Pentanes-plus are more accurately described as natural gas liquids (NGL). Pentanes-plus have a higher carbon content and, consequently, have a higher emissions coefficient than LPG. Thus, their removal from the overall weighted emissions coefficient for LPG lowers the factor by about 1 percent.

Because the densities and carbon contents of pure paraffinic hydrocarbons are well known, carbon emissions coefficients for the four LPG categories are easily derived. These coefficients were then weighted by yearly consumption to yield a series of annual overall LPG emissions coefficients. Propane accounts for the bulk of LPG consumption, between 53 and 63 percent of consumption in each of the past 10 years, and thus has the largest effect on the emissions coefficient. As shown in Table A3, the emissions coefficient for LPG has remained nearly stable over the past decade, varying by less than 1 percent from its low to its high.

\section{Still Gas}

Still gas, sometimes called refinery gas, is a byproduct of petroleum distillation and refining. It results from catalytic and thermal cracking of various crude fractions and has a highly variable composition. Some constituents of still gas, such as propane and methane, have economic value. Others, such as hydrogen sulfide, are considered waste. The gas itself is often sold or reused as a petrochemical feedstock, or purified and sold as pipeline-quality natural gas. On average, approximately 160 cubic feet of still gas are collected for every barrel of light crude oil processed. ${ }^{185}$

Because different refinery operations result in different gaseous byproducts, it is difficult to determine what constitutes "typical" still gas. In last year's report, the emissions coefficient for still gas was based on a "typical" composition found in the Gas Engineers Handbook. ${ }^{186}$ For this report, the ELA obtained and examined three additional samples of still gas. Composition and carbon content varied significantly among the four samples, as do the resulting carbon emissions coefficients.

\footnotetext{
${ }^{183}$ Energy Information Administration, Petroleum Supply Annual, DOE/EIA-0340 (Washington, DC, various years), Table 16.

${ }^{184}$ Energy Information Administration, Petroleum Supply Annual, DOE/EIA-0340 (Washington, DC, various years), Table 17.

${ }^{185}$.F. Bell and H.R. Linden, in American Gas Association, Gas Engineers Handbook (New York, NY: Industrial Press, 1974), p. $3 / 87$.

186J.F. Bell and H.R. Linden, in American Gas Association, Gas Engineers Handbook (New York, NY: Industrial Press, 1974), p. 3/87.
} 
The size of an emissions coefficient for still gas is primarily a function of the ratio of heavier hydrocarbons, such as ethane and propane, to the share of unassociated hydrogen molecules within the sample. The share of unassociated hydrogen found in the four samples examined ranged from a low of 13 percent in sample 1 to a high of 72 percent in sample 3, while collectively ethane and propane had a combined share of 29 percent of sample 1 and only 14 percent of sample 3 (Table A4). The resulting emissions coefficients range from 10.23 million metric tons carbon per quadrillion Btu to a much higher 17.51 million metric tons carbon per quadrillion Btu.
In the absence of any concrete information on the composition of still gas, we are forced into the realm of supposition. Still gas samples with low emissions factors owe this characteristic to a very high proportion of free hydrogen in their composition. Gas streams with a large hydrogen content are likely to be used as refinery or chemical feedstocks, rather than being burned for energy. Therefore, "typical" still gas burned at refineries is likely to be composed largely of less valuable feedstocks, such as methane and carbon monoxide: Consequently, the EIA has decided to continue to use a carbon emissions coefficient of 17.51 million metric tons per quadrillion Btu for still gas.

Table A3. Consumption Shares for Liquid Petroleum Gases by Energy Content, 1984-1994

(Percent)

\begin{tabular}{|c|c|c|c|c|c|c|c|c|c|c|c|}
\hline Fuel (Emissions Coefficient) & 1984 & 1985 & 1986 & 1987 & 1988 & 1989 & 1990 & 1991 & 1992 & 1993 & 1994 \\
\hline Propane $(17.20)$ & 57.3 & 59.6 & 58.6 & 60.8 & 59.2 & 62.5 & 63.2 & 62.5 & 63.1 & 62.5 & NA \\
\hline$n$-Butane (17.72) $\ldots \ldots \ldots$ & 11.2 & 9.0 & 11.7 & 11.3 & 11.8 & 13.5 & 8.6 & 7.5 & 7.8 & 6.0 & NA \\
\hline $\begin{array}{l}\text { Overall Emissions Coefficient } \\
\text { (Million Metric Tons Carbon }\end{array}$ & 1007 & 1000 & 1700 & 170 & 170 & 1707 & $17 n$ & 100 & 1700 & 1000 & Hu \\
\hline
\end{tabular}

NA $=$ not available.

Sources: Characteristics of Compounds: V.B. Guthrie (ed.), Petroleum Products Handbook (New York, NY: McGraw Hill, 1960), p. 3-3. Shares of U.S. Consumption: Energy Information Administration, Petroleum Supply Annual, DOE/EIA-0340 (Washington, DC, various years).

Table A4. Composition, Energy Content, and Emissions Coefficient for Four Samples of Still Gas

\begin{tabular}{|c|c|c|c|c|c|c|}
\hline \multirow[b]{2}{*}{ Sample } & \multicolumn{4}{|c|}{ Composition (Percent) } & \multirow{2}{*}{$\begin{array}{c}\text { Energy Content } \\
\text { (Btu per Cubic Foot) }\end{array}$} & \multirow{2}{*}{$\begin{array}{l}\text { Emissions Coefficient } \\
\text { (Million Metric Tons Carbon } \\
\text { per Quadrillion Btu) }\end{array}$} \\
\hline & Hydrogen & Methane & Ethane & Propane & & \\
\hline Two ........ & 34.7 & 20.5 & 20.5 & 6.7 & 1,143 & 14.33 \\
\hline Three. & 72.0 & 12.8 & 10.3 & 3.8 & 672 & 10.23 \\
\hline Four . . . . . . . & 17.0 & 31.0 & 16.2 & 2.4 & 1,100 & 15.99 \\
\hline
\end{tabular}

Sources: Sample one from J.F. Bell and H.R. Linden, in American Gas Association, Gas Engineers Handbook (New York, NY: Industrial Press, 1974), p. 3/71. Samples two, three, and four from C.R. Guerra, K. Kelton, and D.C. Nielsen, "Natural Gas Supplementation with Refinery Gases and Hydrogen," in Institute of Gas Technology, New Fuels and Advances in Combustion Technologies (Chicago, IL, June 1979). 


\section{Appendix B Uncertainty in Emissions Estimates}

\section{Overview}

In general, emissions estimates in this report were generated by multiplying some activity, such as coal consumption, by an emissions coefficient. The reliability of both the activity data and the emissions coefficients used in this report varies widely. This Appendix discusses the uncertainties associated with the estimates presented in the report.

In general, estimates of carbon dioxide emissions are more reliable than estimates for other gases. While this report does not explicitly calculate uncertainty ranges, it is likely that the estimate of carbon dioxide emissions is accurate to within 5 percent, implying an emissions range from 1.3 billion to 1.5 billion metric tons. To the extent that there is statistical bias in the point estimate, the actual (unobservable) figure is likely to be somewhat higher than the point estimate, because this report is unlikely to have captured all emissions sources.

Estimates of methane emissions are much more uncertain. The level of precision is probably on the order of 30 to 50 percent. Estimates of methane emissions are also likely to understate actual emissions, as a result of the exclusion of sources that are unknown or difficult to quantify.

Nitrous oxide emissions estimates are highly uncertain. Estimates of emissions from nitrogenous fertilizers are accurate to an order of magnitude, making them either the largest source of nitrous oxide emissions or, alternatively, an insignificant source. Coefficients for nitrous oxide emissions from fossil fuel combustion are not available for all sources, and where available, may be unreliable. Additionally, several known sources of nitrous oxide are not measured and therefore are excluded from estimated totals.

\section{Carbon Dioxide}

Most carbon dioxide emissions estimated in this report are the result of the combustion of fossil fuels. The uncertainties in estimates of emissions from fossil fuel combustion can be divided into four types:
- Uncertainties in the volumes of fuel consumed. In general, volumetric fuel data are believed to be fairly reliable, plus or minus about 3 to 5 percent; estimates of total consumption by fuel are more reliable than estimates by sector, or by particular product.

- Uncertainties in the characteristics of fuel consumed. Fuel data are collected on a volume or weight basis, but the density and energy content of fuels must often be estimated. The energy content of natural gas is reliable to 0.5 percent, but the reliability of energy content estimates for coal and petroleum products is lower.

- Uncertainties in the emissions coefficients. Emissions coefficients can be computed with a high degree of precision for a particular fuel sample, based on a laboratory analysis. However, the emissions coefficient for the sample fuel may not match the actual characteristics of fuels consumed. The pipeline-quality natural gas coefficient is probably accurate to within 1 percent, but the reliability of the coal and petroleum product coefficients is lower.

- Uncertainties of coverage, due to excluded or unknown sources of emissions.

\section{Fuel Consumption}

In general, EIA energy statistics are most accurate where the energy industry is highly concentrated and/ or heavily regulated, and least accurate where activities are decentralized, with large numbers of producers or consumers. In the consumption chain for each fossil fuel, there is a point of maximum concentration, and hence maximum accuracy, for data collection.

Coal. Coal production and consumption data are based on weight-short tons of coal. Coal consumption by regulated electric utilities, including both tonnage and energy content, is universally reported to the EIA and the Federal Energy Regulatory Commission (FERC). Utility coal consumption accounts for about 77 percent of U.S. coal consumption. There are likely to be only minor errors (around 1 percent) in reported utility coal consumption. Industrial, residential, and commercial coal consumption estimates are subject to potentially 
larger errors, especially in the counting of residential and commercial sector consumption.

The statistical discrepancy for coal production (the difference between reported consumption and reported production less exports, plus imports, plus stock changes) was on the order of 10 million short tons, or about 1.1 percent of consumption, in 1992.

Natural Gas. Most natural gas is sold or transported by regulated local distribution companies. The statistical discrepancy for natural gas is 1 to 3 percent of consumption, with reported consumption always smaller than reported production. This may imply (as discussed in Chapter 2) some systematic source of underreporting of consumption.

Inaccuracies in natural gas volumetric data come from inherent limitations in the accuracy of natural gas metering, as well as the usual problems of misreporting and timing differences. For example, natural gas consumption by electric utilities, as reported by the utilities, differed by about 0.5 percent from natural gas consumption as reported by natural gas sellers in $1993^{187}$

Petroleum. U.S. petroleum consumption was estimated on the basis of "petroleum products supplied," which means the volume of petroleum products shipped from primary storage facilities. Since there are only about 200 oil refineries in the United States, coverage of crude oil inputs and refinery outputs is generally complete.

The EIA requires a detailed breakdown and accounting of petroleum products produced by refineries, including refinery fuel. There are several statistical anomalies in ELA petroleum data:

- Every year, more crude oil shows up at refineries than can be accounted for by oil production, imports, and stock changes. This "unaccounted for crude oil" typically amounts to 150,000 to 300,000 barrels per day, or between 1 and 2 percent of refinery runs or 1 to 1.5 percent of oil consumption. ${ }^{188}$

- Every year, 80,000 to 150,000 barrels per day more "unfinished oils" show up at refineries than can be accounted for by sales and imports of unfinished oils. ${ }^{189}$ This is about 1.1 percent of refinery runs and 0.9 percent of oil consumption.
By definition, the source of "unaccounted for" crude oil is unknown. It is likely due to imprecisions in recorded crude oil production, import, and stock change data. In EIA's State Energy Data Report, which presents consumption estimates, unaccounted for crude oil is included in consumption.

The unfinished oil discrepancy is probably due to the asymmetric treatment of interrefiner sales of unfinished oils. To the buyer, who knows the intended use of the product, it is motor gasoline or distillate fuel. To the seller, it is an unfinished oil. In the State Energy Data Report, the unfinished oil discrepancy is accounted for through an adjustment to "other oils." However, the implication is that total oil consumption figures are more reliable than the exact distribution of consumption across specific petroleum products.

Overall, it is likely that petroleum consumption estimates are accurate to within 5 percent or so.

Nonfuel Use. Data for nonfuel use of petroleum products are more uncertain than those for total use of petroleum products. There are two main methods of estimating nonfuel use:

- Specialized petroleum products, such as petrochemical feedstocks, waxes and polishes, asphalt, and lubricants, are assumed to be dedicated to nonfuel use.

- Nonfuel use of conventional fuels is estimated on the basis of survey results from EIA's Manufacturing Energy Consumption Survey (MECS), with additional detail from trade association data and from known specific nonfuel uses (such as fertilizer feedstocks for natural gas). ${ }^{190}$ However, MECS is a sample survey conducted only at 3-year intervals, with the sample optimized to detect the use of fuels for heat and power. Using MECS to measure nonfuel use requires interpolating between sample years and correcting for certain sampling problems associated with reported nonfuel use.

The main uncertainty in estimating carbon sequestered from nonfuel use is not the amount of product used, but the fate of its carbon. The sequestration percentages used in this report are estimates, originally based on the typical fate of a particular class of products. The actual distribution of nonfuel uses of products is not always known with precision and could vary consider-

\footnotetext{
${ }^{187}$ Energy Information Administration, Natural Gas Annual 1993, DOE/EIA-0131(93) (Washington, DC, October 1994 ), p. 237.

${ }^{188}$ Energy Information Administration, Petroleum Supply Annual 1994, DOE/EIA-0340(94)/1 (Washington, DC, May 1995 ), p. 6.

${ }^{189}$ Energy Information Administration, Petroleum Supply Annual 1994, DOE/ELA-0340(94)/1 (Washington, DC, May 1995), p. 34.

${ }^{190}$ Energy Information Administration, Manufacturing Consumption of Energy 1991, DOE/EIA-0512(91) (Washington, DC, December 1994).
} 
ably from the "typical" usage. However, since sequestration through nonfuel use corresponds to only about 5 percent of total emissions, even large variations in the amount sequestered would have a small effect on estimated total emissions.

\section{Conversion Factors}

EIA oil and gas data are collected in volumetric units: barrels of oil and billion cubic feet of gas. Carbon emissions factors for fossil fuels usually take the form of tons of carbon per unit of energy content. Emissions factors are computed by dividing the carbon content (by weight) of a particular fuel by its energy content. Thus, in order to match an emissions factor to a fuel accurately, it is necessary to know its energy content with precision; and in the case of fuel quantity based on volumetric data, it is also necessary to know the density of the fuel.

Each step that transforms the data from native units into more useful units inevitably reduces the precision of the resulting data, because the conversion factors are themselves estimates, which may not precisely match the actual composition of the fuel.

Coal. Coal data are collected by State, coal rank, and weight (short tons). Electric utilities are asked to report both the rank and the energy content of the coal they burn. Since, in principle, utilities need to know the energy content of the fuels they purchase with precision, the energy content data should be fairly accurate. On the other hand, there is no direct information about the rank or energy content of coal distributed outside the utility sector, which accounts for about 23 percent of U.S. coal consumption. The EIA's energy data assume that the average energy content of coal by State (except anthracite) in the utility and nonutility sectors is the same.

The quality of coal can vary considerably within States and within a particular rank, and the quality of coal burned outside the utility sector is subject to a considerable degree of uncertainty. Lignite, for example, is defined as containing 6,300 to 8,300 Btu per pound, a range of about 15 percent. Subbituminous coal, by definition, has a range of 8,300 to 11,500 Btu per pound. ${ }^{191}$ Thus, there may be errors of up to 15 percent in the industrial and residential/commercial coal conversion factors. It is likely, however, that the actual (but unobservable) imprecision is much smaller than 15 percent, because there is no reason to expect systematic differences in coal quality between utility and nonutility usage. In any case, residential/commercial and industrial coal consumption accounts for only about 5 percent of total U.S. energy-related carbon emissions. Hence, even large errors would have only a small impact on the ultimate estimates.

Natural Gas. The composition of natural gas also varies considerably. In a recent survey of several thousand gas samples taken from local distribution companies around the United States, the Btu content ranged from 970 to 1,208 Btu per thousand cubic feet. ${ }^{192}$ However, 80 percent of the samples fell within a much narrower range of 1,006 to $1,048 \mathrm{Btu}$ per thousand cubic feet. Further, the average and median values of the samples fell within 0.3 percent of the national-level figure as reported in EIA's Natural Gas Annual. This comparison suggests that EIA data on the energy content of natural gas are accurate to within 0.5 percent. This is not surprising, because local distribution companies monitor the energy content of natural gas to ensure adherence to contractual specifications, and they report the average energy content to the EIA.

Petroleum. The energy content of petroleum products varies more by volume than by weight. The density and the energy content of petroleum products are rarely measured by producers or consumers, and hence they are frequently not known with precision. Electric utilities measure the energy content of the residual oil they burn and report it to the EIA. Liquid petroleum gases (propane, butane, and ethane) are pure compounds, and their energy content can be computed directly.

Liquid transportation fuels (jet kerosene, gasoline, and diesel fuel) are complex mixtures of many compounds, whose physical properties can vary considerably. Their energy content is not measured by consumers nor directly defined by product specifications. The EIA estimates the energy content of these fuels on the basis of standard or "typical" values for each product. The standard energy contents for motor gasoline and kerosene-based jet fuel are drawn from a 1968 report produced by the Texas Eastern Transmission Corporation. ${ }^{193}$ The energy content of distillate fuel oil is drawn from a Bureau of Mines Standard adopted in January $1950 .{ }^{194}$ Jet fuel and diesel samples obtained for this report showed an average energy content that

\footnotetext{
${ }^{191}$ Energy Information Administration, Coal Industry Annual 1993, DOE/EIA-0584(93) (Washington, DC, December 1994 ), Pp. 262 and 266.

${ }^{192}$ W.E. Liss et al., Variability of Natural Gas Composition in Select Major Metropolitan Areas of the United States (Chicago, IL: Gas Research Institute, March 1992), p. 14.

${ }^{193}$ Energy Information Administration, State Energy Data Report 1993, DOE/EIA-0214(93) (Washington, DC, July 1995).

${ }^{194}$ Energy Information Administration, Annual Energy Review 1993, DOE/EIA-0384(93) (Washington, DC, July 1994), Pp. 348-353.
} 
differs from EIA estimates by about 2 percent. Samples of motor gasoline analyzed by the National Institute of Petroleum and Energy Research displayed an average energy content that differs from EIA estimates by less than 0.5 percent.

\section{Carbon Emissions Coefficients}

Carbon emissions coefficients are calculated by dividing the carbon content of a particular fuel (for example, 0.85 metric tons of carbon per metric ton of fuel) by the energy content of that fuel (say, 43 million Btu per metric ton), producing an emissions coefficient (in this example, 19.8 million metric tons of carbon per quadrillion Btu). Both the energy content and the carbon content of the fuel are subject to a degree of uncertainty. The carbon content of fuels has only an indirect and general bearing on their economic value and consequently is not necessarily collected by fuel producers or consumers. While coefficients for coal and natural gas rely on analyses of a large set of fuel samples, coefficients for several petroleum products are based on "typical" or "representative" values, which may or may not perfectly reflect the underlying composition of the fuel. Variation in carbon content is limited to plus or minus 5 percent by the standard ratios of carbon to hydrogen in the hydrocarbon compounds that compose petroleum. ${ }^{195}$

Coal. There are large variations in the carbon and energy content of coals in different parts of the United States. Lignite may have as little as 12.6 million Btu per ton and contain 36 percent carbon, while anthracite may have as much as 98 percent carbon and an energy content as high as 27 million Btu per ton. ${ }^{196}$

The carbon and heating values of coal are, in general, controlled by two factors:

- The ratio of flammable materials (carbon, hydrogen, and sulfur) in coal to nonflammable impurities (ash, etc.)

- The ratio of carbon to hydrogen and sulfur within the flammable portion of the coal.

Most of the gross variation in both energy and carbon content (for example, between lignite and anthracite) is due to variations in nonflammable impurities. Consequently, if the Btu content of coal is estimated accurately, most of the variation in the carbon content is removed.
There is, however, residual uncertainty about the ratio of carbon to hydrogen and sulfur in particular coals. The carbon content of any particular coal sample can be determined by chemical analysis, but characterizing the average carbon content of national coal production creates some uncertainty. For this report, the EIA relied on chemical analyses of several thousand coal samples, sorted by State of origin and coal rank, to compute national weighted average emissions coefficients (in million metric tons of carbon per million Btu) for each coal rank.

Natural Gas. Natural gas also varies in composition, but the range of variation is much smaller than for coal. The emissions coefficient used in this report was based on an analysis of some 6,743 recent samples of U.S. natural gas. While there is some residual uncertainty about the exact carbon content of average U.S. natural gas, it is on the order of 1 percent or less.

Petroleum Products. Crude oil is refined into a wide range of petroleum products, each presenting a different set of uncertainties. In general, the carbon content of petroleum products increases with increasing density. Uncertainties in emissions coefficients arise primarily from picking the wrong density for a fuel, or from mismatching the carbon and energy content of a particular fuel. The emissions factors for liquefied petroleum gas (LPG) and motor gasoline are probably accurate to within 1 to 2 percent. Coefficients for jet fuel and diesel fuel are probably accurate to within 2 to 4 percent, with much of the uncertainty centered in the standard heat contents used. The estimate for residual fuel is more uncertain but probably accurate within 3 to 5 percent, as there are remaining uncertainties about the exact density and carbon content of the fuel.

The uncertainty for some minor petroleum products remains large, in some cases because it has proven difficult to identify exactly how reporters define particular product categories. Products with large remaining uncertainties include petrochemical feedstocks (density and portion of aromatics), lubricants, and waxes and polishes. The uncertainty of the emissions coefficients for these products is probably on the order of 10 percent. Because these products share a large nonfuel use component, their impact on the total carbon emissions figure is muted. Still gas is a highly variable byproduct of the refining process, which is then described as a petroleum product. Thus, the estimated emissions coefficient for still gas may vary by as much as 40 percent.

\footnotetext{
${ }^{195}$ Energy Information Administration, Emissions of Greenhouse Gases in the United States 1987-1992, DOE/EIA-0573 (Washington, DC, November 1994), pp. 78-80.

${ }^{196}$ Energy Information Administration, Monthly Energy Review, DOE/EIA-0035(93/07) (Washington, DC, July 1993), pp. 143 and 149.
} 


\section{"Adjustments to Energy"}

U.S. Territories. Energy data for U.S. territories present certain problems. Published petroleum data for Puerto Rico and the Virgin Islands are considerably less detailed than those for the mainland United States. In particular, there is no estimate of nonfuel use for these territories, and much of the petroleum consumption that could potentially be considered nonfuel use is lumped together into "other petroleum." Hence, the reliability of the emissions estimates is lower than for petroleum emissions estimates generally.

Unmetered Gas Consumption. Since the estimate for unmetered gas consumption is actually a balancing item, the uncertainty of the estimate is very large, on the order of 100 percent. Fortunately, this is only a small source of carbon emissions.

Flare Gas. Estimates of emissions from flare gas are subject to uncertainty from two sources: estimates of the volume of gas flared, and the application of an appropriate emissions coefficient. Estimates of gas flared are based on State-reported volumes of gas "vented or flared" and a State-by-State estimate of the share flared. States may define "flared" gas differently. This suggests that estimates may be upwardly biased by the inclusion of low carbon emitting gases in the statistics, but the degree of bias is unknown.

The emissions coefficient applied to flare gas represents the average coefficient for natural gas samples with heat contents between 1,100 and 1,127 Btu per standard cubic foot. The EIA estimates the heat content of "wet" gas at 1,110 Btu per standard cubic feet. ${ }^{197}$ Anecdotal evidence suggests that most flared gas is flared at gas processing facilities, where the wet gas energy content would be representative. However, if flared gas is mostly "rich" associated gas with a heat content between 1,300 and 1,400 Btu per standard cubic feet, the current coefficient seriously biases estimates downward. Alternatively, it is possible that flare gas from treatment plants is "off spec" gas with a large content of hydrogen sulfide or inert gas and, hence, an emissions coefficient lower than the one actually used.

\section{Other Sources of Carbon Emissions}

The principal source of uncertainty in cement manufacture is the lime content of cement, which is estimated to within about 3 percent. There may also be a degree of imprecision in the estimate of cement production, due to possible production in Puerto Rico (excluded in this report) and limitations on the inherent accuracy of the Interior Department data used to calculate the estimate.

A second source of uncertainty, common to all the industrial estimates, is the use of stoichiometric computations to estimate emissions. This method calculates an emissions factor based on a chemical reaction known to have taken place. It assumes, in effect, that the product produced (cement, lime, soda ash) is 100 percent pure, and that no raw materials are wasted in its production. In practice, impurities in the output would tend to reduce emissions below the stoichiometric estimate, while "wastage" of raw materials would tend to raise emissions above the estimate.

\section{Excluded Sources}

Appendix D lists several sources of emissions that are excluded because of uncertainty. Sources excluded because of insufficient data include emissions from natural gas plants, emissions from shale oil production, and carbon dioxide in geothermal steam. Taking what is known about all excluded sources, additional emissions would probably be less than 10 million metric tons, or less than 1 percent of estimated emissions. Nonetheless, their exclusion does slightly bias the estimate downward. There are almost certainly other sources of carbon emissions unknown to the authors of this report. There is no way to estimate the impact of such unknown additional sources.

\section{Methane}

\section{Overview}

Estimates of methane emissions are, in general, substantially more uncertain than those for carbon dioxide. Methane emissions are rarely systematically measured. Where systematic measurements have been made, data are restricted to a small portion of the emission sites and a few years. In order to extrapolate these data to the full population of emitters, and to develop timeseries emissions estimates, scaling mechanisms must be applied, which may introduce additional error.

Where no systematic measurements have been made, estimation methods rely on a limited set of data applied to a large and diverse group of emitters. However, as additional data comes available each year, uncertainty in emissions estimates declines or, at a minimum, is more clearly delineated. In this year's report, additional information on emissions from coal mines, oil and gas operations, and landfills has been incorporated into the estimates, significantly reducing uncertainty levels.

\footnotetext{
${ }^{197}$ Energy Information Administration, Annual Energy Review 1993, DOE/EIA-0384(93) (Washington, DC, July 1994), p. 344.
} 


\section{Coal Mining}

Methane emissions from coal mining have five sources: ventilation systems in underground mines, degasification systems in underground mines, emissions from surface mines, post-mining activities, and emissions from abandoned or closed mines. Only the first four are included in emissions estimates, because data on emissions from abandoned mines are lacking. This exclusion may bias emissions estimates downward by 5 to 10 percent. The uncertainty associated with estimates of emissions from each of the sources included varies considerably and according to the year of the estimate. Based on comparison with other estimates recently published, the overall uncertainty of estimates for emissions from coal mines is probably about 35 percent. ${ }^{198}$

Emissions from ventilation systems in the Nation's gassiest mines are measured on a quarterly basis by the Mine Safety and Health Administration (MSHA). The Bureau of Mines (BOM) has developed a database from MSHA reports for all mines emitting more than 100,000 cubic feet of gas per day. Data on emissions from this source are available for 1985, 1988, 1990, and 1993. Although the measurements themselves should be reasonably accurate, each measurement represents a point in time. Variations in methane emissions across time (e.g., resulting from changes in operating practices) suggest an uncertainty in the range of 10 to 40 percent.

Estimates of emissions from the ventilation systems of nongassy mines are scaled to emissions estimates for 1988 developed by the U.S. Environmental Protection Agency (EPA). ${ }^{199}$ The EPA estimates emissions from nongassy mines at 2 percent of total emissions from the ventilation systems of underground coal mines. Thus, an error as high as 100 percent for this source would add less than 1 percent to the total estimate.

Emissions from degasification systems may be the single largest source of uncertainty in estimates of emissions from coal mines. The estimation method scales emissions to estimates of emissions for 1988 developed by the EPA. Measurements of emissions were limited to a few mines, with the remainder of the estimate based on known emissions from ventilation systems and estimated recovery efficiencies of degasification systems. The recovery efficiencies have an uncertainty in the neighborhood of 20 percent.

Reliable measurements of emissions from surface mines are available for only five sites. Thus, estimates for this report were based on an emissions range supplied by the Intergovernmental Panel on Climate Change (IPCC) ${ }^{200}$ The range of emissions suggested by the IPCC implies an uncertainty range of plus or minus 75 percent. However, estimates of emissions extrapolated from the five measured sites suggest an uncertainty level of less than 10 percent. ${ }^{201}$ Assuming the larger uncertainty level would add only about 10 percent to the overall uncertainty of estimates of emissions from coal mines, because the volume of emissions from surface mines is relatively insignificant.

Emissions from post-mining activities are also estimated on the basis of an emissions range supplied by the IPCC. This emissions range implies an uncertainty in the area of plus or minus 60 percent. However, the magnitude of emissions from this source is similar to that of emissions from surface mines, thus also contributing about 10 percent to the overall uncertainty of coal mine emissions estimates.

\section{Oil and Gas Operations}

The uncertainty associated with emissions estimates from oil and gas operations can be divided into two areas: uncertainty associated with estimates for production, transmission, and distribution; and uncertainty in estimates of emissions from gas venting.

This report's estimate of emissions from production, transmission, and distribution is based on emissions factors developed from a small sample of model facilities, as recommended by the IPCC. Facility selection was based on accessibility for data collection and operator interviews, size, process type, location, and age. In order to develop time-series emissions estimates, emissions factors for a single year (1990) were scaled to some known activity data, such as pipeline miles. Because newly added pipeline miles are typically plastic

\footnotetext{
${ }^{198}$ S.D. Piccot, S.S. Masemore, E. Ringler, and D.A. Kirchgessner, “Developing Improved Methane Emission Estimates for Coal Mining Operations," Presented at the 1995 Greenhouse Gas Emissions and Mitigation Research Symposium (U.S. Environmental Protection Agency, June 27-29, 1995).

${ }^{199}$ U.S. Environmental Protection Agency, Anthropogenic Methane Emissions in the United States: Estimates for 1990 (Washington, DC, April 1993).

${ }^{200}$ Intergovernmental Panel on Climate Change, Greenhouse Gas Inventory Reference Manual, IPCC Guidelines for National Greenhouse Gas Inventories, Vol. 3 (Paris, France, 1995), pp. 1.98-1.99.

${ }^{201}$ S.D. Piccot, S.S. Masemore, E. Ringler, and D.A. Kirchgessner, "Developing Improved Methane Emission Estimates for Coal Mining Operations," Presented at the 1995 Greenhouse Gas Emissions and Mitigation Research Symposium (U.S. Environmental Protection Agency, June 27-29, 1995).
} 
pipe with low emission rates, this scaling mechanism may bias the estimates upward. Recently, a more extensive, systematic analysis of the oil and gas production and distribution system was completed by Kirchgessner et $\mathrm{al}^{202} \mathrm{~A}$ comparison of their estimates and those that appear in this report indicates a potential underestimate of emissions in excess of 100 percent.

Estimates of emissions from venting are also uncertain. The EIA maintains statistics on gas vented or flared as reported on a State-by-State basis, but no distinction is made between venting and flaring in those statistics. Gas flared releases carbon dioxide rather than methane. This report estimates the national share vented on the basis of the estimated share vented for each State.

An additional uncertainty associated with estimates of methane vented is methane vented at "stripper wells." Associated natural gas production at oil wells producing less than 10 barrels per day may be at pressures and volumes too low to be of commercial value. The gas may be vented or merely evaporate from storage tanks. Such emissions are not captured in any data series. The magnitude of the emissions is impossible to estimate, but "stripper wells" comprise 14 percent of U.S. oil production.

\section{Combustion-Related Emissions}

Most methane emissions from stationary combustion are the result of wood burning in residential woodstoves. Because estimates of wood consumption as well as the maintenance and efficiency of residential woodstoves are highly uncertain, estimates of emissions from this source may vary by more than an order of magnitude.

Methane emissions from mobile combustion may be larger than the estimate offered in this report, but it is unlikely that they are significantly smaller. Emissions factors for mobile transportation assume a wellmaintained fleet. A fleet of inadequately maintained vehicles may have as much as 10 times the level of emissions of a fleet of well-maintained or new vehicles. Although much of the U.S. fleet is well-maintained, a portion is old and/or poorly maintained.

\section{Landfills}

Estimates of methane emissions from landfills were broken into two sources: emissions from waste contained in 105 mostly large landfills with gas recovery systems; and emissions from waste contained in all other landfills. Uncertainties associated with estimates of emissions for these two sources differ substantially.

Emissions for many of the 105 mostly large landfills were estimated for 1992, based on volumes of gas recovered multiplied by gas recovery efficiency ${ }^{203}$ Gas recovery efficiency was estimated, with an associated uncertainty of plus or minus 25 percent. For years other than 1992, emissions from this source were estimated using a model of landfill waste emissions that is benchmarked to the 1992 data. The model parameters include a low yield and high yield scenario that imply an uncertainty of 35 percent.

Emissions from all other landfills were also estimated using an emissions model. This model's input parameters could vary by 30 percent from the mean. A crucial input into the model is amount of waste in place. The amount of waste in place was calculated from estimates of waste landfilled annually between 1960 and 1994 and using a regression equation to backcast waste flows from 1940 to 1960 . The range of published estimates for years in which multiple sources were available suggests an uncertainty in the neighborhood of plus or minus 33 percent, while the error associated with the regression equation probably adds another 2 to 10 percent additional uncertainty. ${ }^{204}$

The ratio of waste in place in the 105 landfills relative to that in all other landfills was assumed to remain constant over time. This may be misleading, since the total number of landfills has been declining, with greater shares of waste believed to be directed toward larger landfills. Because those landfills with measured emissions for 1992 are likely to have higher-than-average emissions per ton of waste, estimates may be biased upward in earlier years.

\footnotetext{
${ }^{202}$ D. Kirchgessner, R.M. Cowgill, M. Harrison, and L.M. Campbell, "Methods for Estimating Methane Emissions from the Domestic Natural Gas Industry," Presented at the 1995 Greenhouse Gas Emissions and Mitigation Research Symposium (U.S. Environmental Protection Agency, National Risk Management Research Laboratory, Air Pollution Prevention Division, June 1995).

${ }^{203}$ S.A. Thorneloe, M.R.J. Doorn, L.A. Stefanski, M.A. Barlaz, R.L. Peer, and D.L. Epperson, "Estimate of Methane Emissions From U.S. Landfills," prepared for U.S. Environmental Protection Agency, Office of Research and Development (April 1994).

${ }^{204}$ Franklin Associates, Ltd., Characterization of Municipal Solid Waste in the United States: 1994 Update (prepared for U.S. Environmental Protection Agency, Office of Solid Waste and Emergency Response); and "1994 Nationwide Survey: The State of Garbage in America," Biocycle (various years).
} 


\section{Enteric Fermentation in Domesticated Animals}

Estimates of methane emissions from enteric fermentation in domesticated animals are less uncertain than those for other sources of methane emissions. Emissions estimates are a function of an emissions factor for each animal group, based on their diet and energy usage multiplied by their population. Animal population data have recently been revised by the U.S. Department of Agriculture, and the magnitude of revisions shows that population estimates are likely to be accurate within 5 percent. The energy requirements and diets of cattleby far the largest source of emissions from enteric fermentation-have been carefully studied. There is some uncertainty associated with estimates of the energy requirements of other animals, but even if this uncertainty was as high as 50 percent, the impact on the overall estimate would be no more than 3 percent.

There is some uncertainty associated with the average size of cattle, which could affect the animals' energy requirements. Cattle sizes have been changing rapidly over the past decade in response to market forces. This report uses slaughter weights as a proxy for average animal size, a method that may be imperfect. The slaughter sizes vary over time by approximately 33 percent.

\section{Solid Waste of Domesticated Animals}

The maximum amount of methane that a given amount of an animal's waste can produce under optimal anaerobic conditions can be measured fairly accurately in the laboratory. However, the share of that production realized under various waste management regimens is much more uncertain. The emissions vary with ambient air temperatures and, depending on the waste management system, may change by anywhere from 1 to 60 percent as the temperature changes. For this report, all animal waste was assumed to be handled at air temperatures between 59 and $77^{\circ} \mathrm{F}$. Overestimating the average temperature at which waste is handled would bias emissions estimates upward.

Emissions are tied to the amount of waste an animal produces. The amount of waste produced is a function of size and diet. Thus, changes in animal sizes, which are difficult to monitor, create additional uncertainty.
As discussed above, slaughter weights have been used as an imperfect tool for capturing changes in animal size. This proxy measure varies by 30 percent over time. Uncertainty in estimates of animal populations is on the order of 5 percent or less.

\section{Wetland Rice Cultivation}

There are large uncertainties associated with the estimate of methane emissions from wetland rice cultivation. Emissions estimates are based on several studies of rice paddies in the United States, which provide daily emissions rate ranges. Studies have shown large seasonal and time-of-day variations in methane flux. Many variables affect methane production in rice fields, including soil temperature, redox potential, and acidity; substrate and nutrient availability; addition of chemical and/or organic fertilizers; rate of methane oxidation; and rice plant variety. The wide range of emissions provided by different researchers suggests an uncertainty of several hundred percent. ${ }^{205}$

\section{Crop Residue Burning}

Estimates of emissions from the burning of crop residues are calculated using the default method recommended by the IPCC. ${ }^{206}$ This method assumes a carbon content of about 45 percent of dry matter and that 10 percent of crop residues are burned. The carbon content probably is uncertain to plus or minus 10 percent, and the share of crop residues burned in the United States is likely to be much smaller than the 10 percent default parameter used. Thus, estimates are likely to overstate actual emissions.

\section{Industrial Processes}

Estimates of methane emissions from industrial processes are highly uncertain because of the wide variety of production processes and inputs. Organic chemical production requires the cracking and reforming of hydrocarbon bonds. How the bonds crack and reform depends on several variables, including the composition of the feedstock, the temperature of the reaction, the catalyst used, and the reaction vessel. As a result, the quantities of products and byproducts, including methane, vary. Methane may be released through leaks in seals and valves. Therefore, methane emissions are

\footnotetext{
${ }^{205}$ R.J. Cicerone, J.D. Shetter, and C.C. Delwiche, "Seasonal Variation of Methane Flux from a California Rice Paddy," Journal of Geophysical Research, Vol. 88 (1983), pp. 7203-7209; C.W. Landau and P.K. Bolich, "Methane Emissions from Louisiana First and Ratoon Crop," Soil Science, Vol. 156 (1993), pp. 42-48; R.L. Sass, F.M. Fisher, S. Lewis, M. Jund, and F. Turner, "Methane Emissions from Rice Fields: Effect of Soil Properties," Global Biogeochemical Cycles, Vol. 8 (1994), p. 135; R.L. Sass, F.M. Fisher, and Y.B. Wang, "Methane Emissions From Rice Fields: The Effect of Floodwater Management," Global Biogeochemical Cycles, Vol. 6 (1992), pp. $249-262$.

${ }^{206}$ Intergovernmental Panel on Climate Change, Greenhouse Gas Inventory Reference Manual, IPCC Guidelines for National Greenhouse Gas Inventories, Vol. 3 (Paris, France, 1995), Pp. 4.69-4.72.
} 
dependent on the operation and maintenance practices of the producer.

\section{Excluded Sources}

Appendix D lists several sources excluded because of excessive uncertainty or insufficient data. Known sources excluded from methane emissions estimates are wastewater treatment plants, abandoned coal mines, industrial landfills, and open dumps. There are other sources of methane that have yet to be identified and thus are absent from emissions estimates. Excluded sources would invariably add to total emissions, but the magnitude of the additions is impossible to estimate.

\section{Nitrous Oxide}

\section{Fertilizer}

A number of variables are necessary for accurate calculation of nitrous oxide emissions from the application of fertilizer. They may include crop type, soil type, nutrient content of the fertilizer, agricultural management practices, and even climate. In fact, researchers maintain different opinions about the effects, if any, of these variables. While it may be possible to quantify some of the variables, it is highly unlikely that within the next few years sufficient studies will be conducted to determine a precise emissions factor. Therefore, the uncertainty range for the estimate presented in this report is an order of magnitude. Additionally, the estimate does not take into account organic fertilizer from human or farm animal excreta. Although the data are limited, emissions from this type of fertilizer are generally greater than those from mineral fertilizer. ${ }^{207}$

\section{Crop Residue Burning}

The accuracy of emissions estimates for crop residue burning is limited, because the practice of burning crop residues in the United States has not been quantified. As described in Chapter 4, a default figure of 10 percent was used in the calculation. This figure is believed to be a maximum representation of the practice, and could possibly be as much as an order. of magnitude high.

\section{Stationary Source Combustion}

As the result of improved studies, emissions factors recommended by the IPCC are now limited to one value for each fuel type, regardless of application. Although the emissions factor for coal is 1.4 kilograms of nitrous oxide per terajoule of energy input, emissions may range from 0 to 10 kilograms. For oil, the recommended emissions factor is 0.6 kilogram, with a possible range of 0 to 2.8 kilograms. The range is smallest for natural gas (0 to 1.1 kilograms), with 0.1 kilogram as the suggested factor. ${ }^{208}$

The emissions factors were derived from studies of "conventional" combustion facilities (i.e., those equipped with burners and grate combustion, with flame temperatures well beyond $1,000^{\circ} \mathrm{C}$ ). Other types of facilities are used in the United States, adding to the uncertainty of estimates presented in this report.

\section{Adipic Acid Production}

For adipic acid production, emissions estimates are based on three data inputs: production activity, an emissions factor, and emissions abatement activity. The primary reasons for uncertainty are that the amount of production at plants with emissions abatement is unknown, and the effectiveness of those abatement techniques in eliminating nitrous oxide is unknown. Additionally, the emissions factor for adipic acid production was determined by stoichiometry. This may be an imprecise figure if the conversion of nitric acid to adipic acid is less than 100 percent efficient.

\section{Nitric Acid Production}

The emissions factor for nitric acid production is also uncertain. The DuPont data indicate a range of emissions from 2 to 9 grams of nitrous oxide per kilogram of acid production. Since the midpoint of this range was used in the calculation, estimates may err by as much as 65 percent. As explained in Chapter 4, applying this emissions factor range to total production also adds uncertainty, because the emissions reported at the DuPont plant may not be representative of emissions at all nitric acid production plants.

\footnotetext{
${ }^{207}$ A.R. Mosier, "Nitrous Oxide Emissions from Agricultural Soils," in A.R. van Amstel (ed.), International IPCC Workshop Proceedings: Methane and Nitrous Oxide, Methods in National Emissions Inventories and Options for Control (Bilthoven, Netherlands: RIVM, 1993), p. 278.

${ }^{208}$ Intergovernmental Panel on Climate Change, Greenhouse Gas Inventory Reference Manual, IPCC Guidelines for National Greenhouse Gas Inventories, Vol. 3 (Paris, France, 1995), p. 1.50.
} 


\section{Criteria Pollutants}

The emissions estimates presented in Chapter 6 are taken from data in National Air Pollutant Emission Trends, 1900-1993, a report published by the EPA Office of Air Quality Planning and Standards. Although true values of criteria pollutant emissions are not known, the EPA states that, "beginning with the 1900 to 1992 report, EPA set the primary goal of preparing emission trends that would also represent the best available estimates of emissions. ${ }^{209}$ The EPA also explains that one of the difficulties they experience in providing emissions estimates is balancing consistency of estimation methods with completeness and accuracy of data. Therefore, as new methods and data become available, emissions estimates may be revised. As an example, the estimates for 1992 emissions were increased by 10 percent for carbon monoxide in the latest Trends report, due in part to an improved method for estimating emissions from highway vehicles. Estimates for nitrogen oxides and nonmethane volatile organic compounds were revised by less than 2 percent. ${ }^{210}$

\section{Land Use Issues}

Obtaining accurate estimates for greenhouse gas emissions and sequestration related to land use is a difficult endeavor. Consumption of resources that sell in markets is often easily measured, as are corresponding emissions rates. Not so for nonmarket resources. These estimates are usually calculated by scientists from small sample measurements extrapolated to much larger areas, with corresponding error. For example, a great deal of data is collected annually on the quantity of wood extracted from U.S. forests, but the data are invariably expressed in terms of the small portion (less than 50 percent) of each tree that can be converted to marketable wood products. The rest is ignored. Researchers cope with this problem by creating ratios of marketable to unmarketable tree volume and applying them to commercial data, but such ratios can only serve as rough approximations.

Carbon dioxide is by far the most important greenhouse gas. Chapter 7 of this report reflects the disproportionate importance of forestland in the carbon budget. Most of the estimates for forest carbon sequestration and emissions came from the U.S. Department of Agriculture (USDA) Forest Service scientist Richard Birdsey. His estimation methods were inclusive of all forest carbon, including all above- and below-ground portions of all live and dead trees; all soil carbon; all carbon contained in dead organic matter on the forest floor; and all carbon in understory vegetation. Mr. Birdsey obtained his data primarily from statewide USDA forest inventories, a nationwide biomass study prepared by the USDA Forest Service, and a special report containing estimates of the proportion of tree volume that is below ground. These sources are subject to sampling errors, estimation errors, and errors in converting data from one reporting unit to another. There is also error in determining the carbon content of wood. Finally, many estimates from forest ecosystem studies were used to predict carbon quantities in other ecosystems or large geographic areas, with corresponding potential for error.

The Birdsey estimate for forest carbon sequestration is a net 106 million metric tons from all U.S. forests in 1987. This is based on an estimated 461 million metric tons of sequestration overall, reduced by 355 million metric tons for timber harvest, land clearing, and fuelwood use. Of the available estimates, this is the lowest and hence most conservative. The EPA estimated net carbon flux at 114 million metric tons in 1990, ${ }^{211}$ and Birdsey himself tentatively raised the figure, based on the latest survey of forest areas in the United States conducted by the USDA Forest Service, to 130 million metric tons in 1992. ${ }^{212}$ The consensus is on a net sequestration rate in the range of 110 to 130 million metric tons for the early 1990s.

\footnotetext{
${ }^{209}$ U.S. Environmental Protection Agency, Office of Air Quality Planning and Standards, National Air Pollutant Emission Trends, 1900-1993, EPA-454/R-94-027 (Research Triangle Park, NC, October 1994), p. 1-3.

${ }^{210}$ The emissions estimate for nitrogen oxides was lowered by approximately 0.7 percent, while the estimate for NMVOCs was increased by approximately 1.3 percent.

${ }^{211}$ U.S. Environmental Protection Agency, The Forest Sector Carbon Budget of the United States: Carbon Pools and Flux Under Alternative Policy Options, EPA/600/3-93/093 (Washington, DC, May 1993), p. xiii.

${ }^{212}$ Cited in U.S. Department of Energy, The Climate Change Action Plan: Technical Supplement, DOE/PO-0011 (Washington, DC, March 1994), p. 30.
} 


\section{Appendix C Detailed Emissions Estimates and Activity Data}

Table C1. U.S. Carbon Dioxide Emissions from Energy Use in the Residential Sector, 1983-1994 (Million Metric Tons of Carbon)

\begin{tabular}{|c|c|c|c|c|c|c|c|c|c|c|c|c|}
\hline \multicolumn{13}{|l|}{ Petroleum } \\
\hline$\ldots \ldots \ldots$ & 6.0 & 4.9 & 5.5 & 5.5 & 6.1 & 6.0 & 6.8 & 6.2 & 6.6 & 6.5 & 6.7 & 7.4 \\
\hline Kerosene...$\ldots \ldots \ldots$ & 1.7 & 1.7 & 3.1 & 2.4 & 2.3 & 2.8 & 2.3 & 1.2 & 1.4 & 1.3 & 1.5 & 1.5 \\
\hline$\ldots \ldots \ldots \ldots$ & 25.9 & 25.6 & 28.3 & 27.8 & 28.8 & 29.8 & 29.7 & 24.0 & 24.4 & 24.8 & 26.2 & 27.6 \\
\hline Coal $\ldots \ldots \ldots \ldots$ & 1.9 & 2.1 & 1.8 & 1.8 & 1.7 & 1.7 & 1.5 & 1.6 & 1.4 & 1.5 & 1.5 & 1.5 \\
\hline
\end{tabular}

\footnotetext{
$P=$ preliminary data.
}

Notes: Data in this table are revised from the data contained in the previous EIA report, Emissions of Greenhouse Gases in the United States 1987-1992, DOE/EIA0573 (Washington, DC, November 1994). Totals may not equal sum of components due to independent rounding.

Source: Energy Information Administration estimates, based on energy data from State Energy Data Report 1993, DOE/ElA-0214(93) (Washington, DC, July 1995), and Monthly Energy Review, DOE/EIA-0535(95/07) (Washington, DC, July 1995), and emissions coefficients shown in Table 6 of this report.

Table C2. U.S. Carbon Dioxide Emissions from Energy Use in the Commercial Sector, 1983-1994 (Million Metric Tons of Carbon)

\begin{tabular}{|c|c|c|c|c|c|c|c|c|c|c|c|c|}
\hline Fuel & 1983 & 1984 & 1985 & 1986 & 1987 & 1988 & 1989 & 1990 & 1991 & 1992 & 1993 & P1994 \\
\hline \multicolumn{13}{|l|}{ Petroleum } \\
\hline Motor Gasoline & 2.0 & 2.1 & 1.8 & 2.0 & 2.1 & 2.1 & 2.0 & 2.1 & 1.6 & 1.5 & 0.6 & 0.6 \\
\hline LPG & 1.1 & 0.9 & 1.0 & 1.0 & 1.1 & 1.1 & 1.2 & 1.1 & 1.2 & 1.1 & 1.2 & 1.3 \\
\hline Distillate Fuel $\ldots \ldots \ldots$. & 12.9 & 13.5 & 12.3 & 11.8 & 11.7 & 11.3 & 10.6 & 9.6 & 9.5 & 9.2 & 9.2 & 9.5 \\
\hline Residual Fuel $\ldots \ldots \ldots$. & 4.4 & 5.6 & 4.8 & 6.2 & 5.6 & 5.6 & 4.9 & 5.0 & 4.5 & 4.1 & 3.7 & 3.8 \\
\hline Kerosene ...... & 2.2 & 1.8 & 0.6 & 1.0 & 0.9 & 0.5 & 0.5 & 0.2 & 0.2 & 0.2 & 0.3 & 0.3 \\
\hline Total ..... & 22.5 & 23.8 & 20.6 & 21.9 & 21.4 & 20.6 & 19.2 & 18.0 & 17.1 & 16.1 & 14.9 & 15.4 \\
\hline Coal $\ldots \ldots \ldots \ldots \ldots \ldots$ & 3.0 & 3.2 & 2.7 & 2.7 & 2.6 & 2.6 & 2.3 & 2.4 & 2.2 & 2.2 & 2.2 & 2.2 \\
\hline Natural Gas .... & 36.1 & 37.3 & 36.0 & 34.3 & 36.0 & 39.5 & 40.3 & 38.8 & 40.4 & 41.5 & 43.1 & 43.6 \\
\hline Electricity ...... & 118.5 & 124.4 & 130.2 & 131.5 & 137.2 & 144.8 & 148.3 & 147.5 & 146.7 & 145.6 & 151.8 & 155.7 \\
\hline Total $\ldots \ldots \ldots \ldots \ldots \ldots$ & 180.0 & 188.8 & 189.6 & 190.4 & 197.2 & 207.6 & 210.0 & 206.7 & 206.4 & 205.5 & 212.1 & 216.9 \\
\hline
\end{tabular}

\footnotetext{
$P=$ preliminary data.
}

Notes: Data in this table are revised from the data contained in the previous EIA report, Emissions of Greenhouse Gases in the United States 1987-1992, DOE/EIA0573 (Washington, DC, November 1994). Totals may not equal sum of components due to independent rounding.

Source: Energy Information Administration estimates, based on energy data from State Energy Data Report 1993, DOE/EIA-0214(93) (Washington, DC, July 1995), and Monthly Energy Review, DOE/EIA-0535(95/07) (Washington, DC, July 1995), and emissions coefficients shown in Table 6 of this report. 
Table C3. U.S. Carbon Dioxide Emissions from Energy Use in the Industrial Sector, 1983-1994 (Million Metric Tons of Carbon)

\begin{tabular}{|c|c|c|c|c|c|c|c|c|c|c|c|c|}
\hline Fuel & 1983 & 1984 & 1985 & 1986 & 1987 & 1988 & 1989 & 1990 & 1991 & 1992 & 1993 & P1994 \\
\hline \multicolumn{13}{|l|}{ Petroleum } \\
\hline Motor Gasoline . . . . . . . & 2.2 & 3.1 & 4.2 & 4.0 & 3.9 & 3.7 & 3.8 & 3.5 & 3.7 & 3.7 & 3.5 & 3.5 \\
\hline LPG $\ldots \ldots \ldots \ldots \ldots$ & 13.4 & 16.5 & 16.9 & 16.0 & 13.8 & 13.6 & 12.6 & 9.8 & 10.3 & 11.8 & 8.6 & 9.8 \\
\hline Distillate Fuel . . . . . . . . & 22.6 & 23.5 & 23.4 & 23.7 & 24.2 & 24.1 & 22.7 & 23.3 & 22.5 & 22.6 & 21.7 & 22.3 \\
\hline Residual Fuel . . . . . . . & 16.8 & 18.9 & 15.9 & 15.7 & 12.4 & 11.6 & 8.8 & 8.9 & 7.1 & 8.3 & 9.6 & 8.9 \\
\hline Lubricants .. & 1.7 & 1.8 & 1.7 & 1.6 & 1.8 & 1.8 & 1.8 & 1.9 & 1.7 & 1.7 & 1.7 & 1.8 \\
\hline Kerosene . . . . . . . . . & 1.3 & 1.1 & 0.9 & 0.6 & 0.6 & 0.6 & 0.6 & 0.2 & 0.2 & 0.2 & 0.3 & 0.3 \\
\hline Other $\ldots \ldots \ldots \ldots \ldots$ & 34.9 & 39.0 & 36.7 & 36.7 & 39.8 & 44.9 & 43.8 & 51.5 & 42.9 & 49.8 & 47.1 & 50.4 \\
\hline Total $\ldots \ldots \ldots \ldots$ & 92.8 & 103.9 & 99.7 & 98.3 & 96.5 & 100.3 & 94.0 & 99.2 & 88.4 & 98.1 & 92.5 & 96.9 \\
\hline Coal . . . . . . . . . . & 60.1 & 69.5 & 67.4 & 64.7 & 66.0 & 71.2 & 69.5 & 68.5 & 64.8 & 63.0 & 62.3 & 62.8 \\
\hline Natural Gas . . . . . . . . & 95.2 & 104.2 & 99.0 & 93.3 & 102.0 & 107.0 & 113.1 & 118.5 & 121.2 & 126.1 & 131.6 & 133.5 \\
\hline Electricity . . & 148.1 & 156.8 & 158.0 & 152.7 & 158.1 & 165.5 & 169.1 & 166.2 & 162.3 & 166.5 & 167.5 & 168.2 \\
\hline Total $\ldots \ldots \ldots \ldots$ & 396.2 & 434.4 & 424.1 & 409.0 & 422.7 & 444.1 & 445.6 & 452.4 & 436.6 & 453.6 & 454.0 & 461.4 \\
\hline
\end{tabular}

$P=$ preliminary data.

Notes: Data in this table are revised from the data contained in the previous ElA report, Emissions of Greenhouse Gases in the United States 1987-1992, DOE/EIA0573 (Washington, DC, November 1994). Totals may not equal sum of components due to independent rounding.

Source: Energy Information Administration estimates, based on energy data from State Energy Data Report 1993, DOE/EIA-0214(93) (Washington, DC, July 1995), and Monthly Energy Review, DOE/EIA-0535(95/07) (Washington, DC, July 1995), and emissions coefficients shown in Table 6 of this report.

Table C4. U.S. Carbon Dioxide Emissions from Energy Use in the Transportation Sector, 1983-1994 (Million Metric Tons of Carbon)

\begin{tabular}{|c|c|c|c|c|c|c|c|c|c|c|c|c|}
\hline \multicolumn{13}{|l|}{ Petroleum } \\
\hline Motor Gasoline & 239.9 & 241.6 & 245.1 & 252.8 & 259.0 & 264.9 & 264.2 & 260.9 & 259.5 & 263.4 & 269.3 & 273.5 \\
\hline Jet Fuel & 41.2 & 46.5 & 48.0 & 51.6 & 54.6 & 57.3 & 58.8 & 60.1 & 58.1 & 57.6 & 58.1 & 60.4 \\
\hline Distillate Fuel & 57.4 & 62.1 & 63.3 & 65.3 & 66.9 & 72.9 & 75.8 & 75.7 & 72.6 & 75.3 & 77.3 & 80.3 \\
\hline Residual Fuel $\ldots . \ldots \ldots$ & 17.5 & 17.2 & 16.7 & 18.5 & 19.2 & 19.6 & 20.8 & 21.9 & 22.0 & 23.0 & 19.4 & 19.2 \\
\hline Natural Gas & 7.3 & 7.8 & 7.5 & 7.2 & 7.7 & 9.1 & 9.4 & 9.8 & 8.9 & 8.8 & 9.3 & 9.4 \\
\hline Electricity & 0.6 & 0.7 & 0.7 & 0.7 & 0.7 & 0.7 & 0.7 & 0.7 & 0.7 & 0.7 & 0.7 & 0.7 \\
\hline Total $\ldots \ldots$. & 366.9 & 379.0 & 384.4 & 399.1 & 411.1 & 427.5 & 432.7 & 432.1 & 424.5 & 431.4 & 436.7 & 446.3 \\
\hline
\end{tabular}

$P=$ preliminary data.

Notes: Data in this table are revised from the data contained in the previous ElA report, Emissions of Greenhouse Gases in the United States 1987-1992, DOEJEIA0573 (Washington, DC, November 1994). Totals may not equal sum of components due to independent rounding.

Source: Energy Information Administration estimates, based on energy data from State Energy Data Report 1993, DOE/EIA-0214(93) (Washington, DC, July 1995). and Monthly Energy Review, DOEJEIA-0535(95/07) (Washington, DC, July 1995), and emissions coefficients shown in Table 6 of this report.

Table C5. U.S. Carbon Dioxide Emissions from Electric Utilities, 1983-1994

(Million Metric Tons of Carbon)

\begin{tabular}{|c|c|c|c|c|c|c|c|c|c|c|c|c|}
\hline Fuel & 1983 & 1984 & 1985 & 1986 & 1987 & 1988 & 1989 & 1990 & 1991 & 1992 & 1993 & P1994 \\
\hline Petroleum & 32.7 & 27.3 & 23.1 & 30.8 & 26.7 & 33.2 & 35.7 & 26.6 & 25.1 & 20.3 & 22.5 & 20.6 \\
\hline Heavy Fuel Oil & 30.6 & 25.3 & 21.2 & 28.9 & 24.6 & 30.7 & 32.4 & 24.2 & 22.9 & 18.2 & 20.0 & 18.0 \\
\hline Light Fuel Oil & 1.9 & 1.7 & 1.7 & 1.6 & 1.8 & 2.2 & 2.9 & 1.7 & 1.6 & 1.3 & 1.5 & 1.9 \\
\hline Petroleum Coke & 0.2 & 0.2 & 0.2 & 0.3 & 0.3 & 0.3 & 0.4 & 0.7 & 0.6 & 0.8 & 1.0 & 0.7 \\
\hline$\ldots \ldots$ & 334.6 & 354.3 & 370.3 & 365.9 & 383.7 & 403.7 & 406.5 & 409.0 & 407.3 & 411.9 & 428.6 & 430.4 \\
\hline Natural Gas ...... & 43.1 & 46.3 & 45.5 & 38.7 & 42.2 & 39.0 & 41.2 & 41.2 & 41.1 & 40.7 & 39.5 & 44.0 \\
\hline Total $\ldots \ldots \ldots \ldots$ & 410.4 & 427.9 & 438.9 & 435.4 & 452.6 & 475.9 & 483.5 & 476.9 & 473.5 & 472.9 & 490.6 & 494.9 \\
\hline
\end{tabular}

$P=$ preliminary data.

Notes: Electric utilities include Independent Power Producers but exclude cogeneration facilities. Data in this table are revised from the data contained in the previous EIA report, Emissions of Greenhouse Gases in the United States 1987-1992, DOE/EIA-0573 (Washington, DC, November 1994). Totals may not equal sum of components due to independent rounding.

Source: Energy Information Administration estimates, based on energy data from State Energy Data Report 1993, DOE/EIA-0214(93) (Washington, DC, July 1995), and Monthly Energy Review, DOE/EIA-0535(95/07) (Washington, DC, July 1995), and emissions coefficients shown in Table 6 of this report. 
Table C6. Production Data for Industrial Sources of Carbon Dioxide, 1983-1994 (Thousand Metric Tons)

\begin{tabular}{|c|c|c|c|c|c|c|c|c|c|c|c|c|}
\hline Cement Clinker & 57,703 & 62,467 & 60,140 & 62,252 & 62,328 & 62,727 & 62,847 & 63,313 & 61,595 & 62,171 & 65,745 & 68,510 \\
\hline Masonry Cement & 2,658 & 2,980 & 2,955 & 3,237 & 3,302 & 3,261 & 2,988 & 2,911 & 2,591 & 2,805 & 2,962 & 3,613 \\
\hline Limestone in Iron Smelting & 5,239 & 6,048 & 6,857 & 5,468 & 4,080 & 4,177 & 4,275 & 3,955 & 3,634 & 3,098 & 2,561 & 2,538 \\
\hline Limestone in Steelmaking . . & 662 & 834 & 689 & 734 & 796 & 866 & 1,058 & 682 & 738 & 612 & 1,087 & 1,117 \\
\hline Limestone in Glass $\ldots \ldots \ldots$ & 1,193 & 780 & 366 & 526 & 685 & 463 & 241 & 255 & 269 & 354 & 439 & 482 \\
\hline Soda Ash in Glass . & 3,130 & 3,085 & 3,084 & 3,152 & 3,343 & 3,390 & 3,294 & 3,177 & 2,997 & 3,082 & 3,095 & 3,150 \\
\hline Soda Ash in FGD .... & 154 & 154 & 157 & 168 & 206 & 211 & 222 & 179 & 155 & 156 & 146 & 173 \\
\hline Sodium Silicate . . . . . . . . & 644 & 621 & 628 & 717 & 863 & 736 & 792 & 740 & 789 & 755 & 889 & 952 \\
\hline Sodium Tripolyphosphate .. & 607 & 628 & 555 & 560 & 532 & 498 & 526 & 451 & 419 & 399 & 426 & 423 \\
\hline Aluminum Manufacture $\ldots$ & 3,352 & 4,099 & 3,500 & 3,037 & 3,343 & 3,944 & 4,030 & 4,048 & 4,121 & 4,042 & 3,695 & 3,300 \\
\hline
\end{tabular}

$P=$ preliminary data.

Sources: U.S. Department of the Interior, Bureau of Mines, Mineral Commodity Summaries (Washington, DC, various years). U.S. Department of the Interior, Bureau of Mlnes, Cement Annual Report (Washington, DC, various years). American Iron and Steel Institute, Annual Statistical Report (Washington, DC, various years). U.S. Department of the Interior, Bureau of Mines, Soda Ash Annual Report (Washington, DC, various years) (soda ash production calculated from quantity of trona ore production). U.S. Department of the Interior, Bureau of Mines, Crushed Stone Annual Report (Washington, DC, various years). Chemical Manufacturers Association, U.S. Chemical Industry Statistical Handbook 1993 (Washington, DC, September 1993). Energy Information Administration unpublished survey data, Steam Electric Plant Operation and Design Report, Form ElA-767 (Washington, DC, various years). Freedonia Group, Inc., Carbon Dioxide, Business Research Report B286 (Cleveland, $\mathrm{OH}$, November 1991), and Carbon Dioxide, Industry Study 564 (Cleveland, $\mathrm{OH}$, February 1994).

Table C7. U.S. Coal Production, 1983-1994 (Million Short Tons)

\begin{tabular}{|c|c|c|c|c|c|c|c|c|c|c|c|c|}
\hline Mine Type & 1983 & 1984 & 1985 & 1986 & 1987 & 1988 & 1989 & 1990 & 1991 & 1992 & 1993 & P1994 \\
\hline Underground . & 300.4 & 352.1 & 350.8 & 360.4 & 372.9 & 382.2 & 393.8 & 424.5 & 407.2 & 407.2 & 386.4 & NA \\
\hline Surface $\ldots \ldots \ldots \ldots$ & 481.7 & 543.9 & 532.8 & 529.9 & 545.9 & 568.1 & 586.9 & 604.5 & 588.8 & 590.3 & 560.2 & NA \\
\hline Total . . . . . . . . . . & 782.1 & 895.9 & 883.6 & 890.3 & 918.8 & 950.3 & 980.7 & $1,029.1$ & 996.0 & 997.5 & 946.6 & $1,030.6$ \\
\hline
\end{tabular}

NA $=$ not available. $P=$ preliminary data.

Source: Energy Information Administration, Coal Industry Annual 1993, DOE/EIA-0584(93) (Washington, DC, December 1994); and Coal Production, DOEJEIA-0118 (Washington, DC, various years). 
Table C8. Activity Data for Methane Emissions from Oil and Gas Production, Processing, and Distribution, 1983-1994

\begin{tabular}{|c|c|c|c|c|c|c|c|c|c|c|c|c|c|}
\hline Item & Units $^{a}$ & 1983 & 1984 & 1985 & 1986 & 1987 & 1988 & 1989 & 1990 & 1991 & 1992 & 1993 & 1994 \\
\hline Natural Gas Wellheads . . & Thousand Wells & 222 & 234 & 242 & 242 & 249 & 257 & 263 & 270 & 277 & 276 & 284 & 288 \\
\hline Producing Oil Wells . . . . . . . . . & Thousand Wells & 603 & 621 & 647 & 629 & 620 & 627 & 607 & 602 & 610 & 594 & 584 & 582 \\
\hline Gathering Pipelines & Thousand Wells & 92 & 94 & 94 & 94 & 94 & 92 & 91 & 90 & 86 & 86 & 77 & 77 \\
\hline Total Gas Throughput . . & Tcf & 13 & 14 & 13 & 13 & 13 & 13 & 13 & 15 & 16 & 16 & 16 & 17 \\
\hline Total Gas Withdrawals . . . . . . . & Tcf & 19 & 20 & 20 & 19 & 20 & 21 & 21 & 22 & 22 & 22 & 23 & 24 \\
\hline $\begin{array}{l}\text { Transmission System Pipelines . . } \\
\text { Distribution Pipeline }\end{array}$ & Thousand Miles & 274 & 272 & 271 & 271 & 274 & 275 & 276 & 280 & 282 & 285 & 272 & 278 \\
\hline Main Pipeline & Thousand Miles & 730 & 737 & 753 & 769 & 784 & 800 & 818 & 837 & 858 & 883 & 914 & 965 \\
\hline Plastic .... & Thousand Miles & 103 & 114 & 126 & 138 & 152 & 166 & 183 & 202 & 222 & 244 & 269 & 295 \\
\hline Nonplastic . . . . . & Thousand Miles & 626 & 623 & 628 & 631 & 632 & 634 & 635 & 635 & 636 & 639 & 646 & 670 \\
\hline Service Pipeline $\ldots \ldots \ldots \ldots \ldots$ & Thousand Miles & 415 & 436 & 389 & 400 & 411 & 449 & 461 & 474 & 494 & 494 & 515 & 515 \\
\hline Plastic ... & Thousand Miles & 0 & 0 & 140 & 151 & 163 & 201 & 212 & 226 & 246 & 246 & 267 & 267 \\
\hline Nonplastic & Thousand Miles & 248 & 248 & 248 & 248 & 248 & 248 & 248 & 248 & 248 & 248 & 248 & 248 \\
\hline $\begin{array}{l}\text { Total Distribution Pipeline . . . . } \\
\text { Marine Transport }\end{array}$ & Thousand Miles & 415 & 436 & 389 & 400 & 411 & 449 & 461 & 474 & 494 & 494 & 515 & 515 \\
\hline Net Crude Imports & Kbd & 3,329 & 3,426 & 3,201 & 4,178 & 4,674 & 5,107 & 5,843 & 5,894 & 5,782 & 6,083 & 6,787 & 7,063 \\
\hline Net Crude Exports $\ldots \ldots \ldots \ldots$ & Kbd & 164 & 181 & 204 & 154 & 151 & 155 & 142 & 109 & 116 & 89 & 98 & 99 \\
\hline Alaskan Crude Production . . . . . . & Kbd & 1,714 & 1,722 & 1,825 & 1,867 & 1,962 & 2,017 & 1,874 & 1,773 & 1,798 & 1,714 & 1,582 & 1,559 \\
\hline Total Marine Transport . . . . . . & Kbd & 5,207 & 5,329 & 5,230 & 6,199 & 6,787 & 7,279 & 7,859 & 7,776 & 7,696 & 7,886 & 8,467 & 8,721 \\
\hline Refinery Crude Input . . . . . . . . & Mbd & 12 & 12 & 12 & 13 & 13 & 13 & 13 & 13 & 13 & 13 & 14 & 14 \\
\hline
\end{tabular}

${ }^{\mathrm{a}}$ Units: Tcf = trillion cubic feet; $\mathrm{Kbd}=$ thousand barrels per day; $\mathrm{Mbd}=$ million barrels per day.

NA = not available.

Sources: Natural Gas Wellheads, Total Gas Throughput, and Total Gas Withdrawals-Energy Information Administration, Natura/ Gas Annual, DOE/EIA-0131 (various years). Producing Oil Wells-World Oil, February issue (various years). Gathering Pipelines, Transmission Pipelines, and Distribution Pipelines-American Gas Association, Gas Facts (various years). Net Crude Imports, Net Crude Exports, Refinery Crude Input, and Alaskan Crude Production-Energy Information Administration, Petroleum Supply Annual, DOEJEIA-0340 (various years).

Table C9. Methane Emissions Factors for Oil and Gas Production, Processing, and Distribution

\begin{tabular}{|c|c|c|c|}
\hline Emissions Source & Coefficient & Unit & Reference \\
\hline \multicolumn{4}{|l|}{ Oil and Gas Production } \\
\hline Natural Gas Wellheads & 0.870 & Metric tons per well & ElA Estimate ${ }^{a}$ \\
\hline Oil Wells $\ldots \ldots \ldots \ldots \ldots \ldots \ldots$ & 0.072 & Metric tons per well & ElA Estimate ${ }^{a}$ \\
\hline Gathering Pipelines $\ldots \ldots \ldots \ldots \ldots \ldots$ & 3.590 & Metric tons per mile & EIA Estimate ${ }^{\mathbf{a}}$ \\
\hline Gas Processing Plants . . . . . . . . . . & 6.160 & Metric tons per billion cubic feet of throughput & EIA Estimate ${ }^{a}$ \\
\hline Heaters, Separators, Dehydrators . . . . . . . & 21.870 & Metric tons per billion cubic feet of gross withdrawals & ElA Estimate ${ }^{\mathbf{a}}$ \\
\hline Transmission Pipeline . . . . . . . . . . . . & 3.713 & Metric tons per mile & EIA Estimate ${ }^{a}$ \\
\hline Plastic Distribution Pipeline $\ldots \ldots \ldots \ldots \ldots$. . & 0.020 & Metric tons per mile & EPA, $1993^{\mathrm{b}}$ \\
\hline Nonplastic Distribution Pipeline ........... & 0.180 & Metric tons per mile & EPA, $1993^{b}$ \\
\hline Gate Stations $\ldots \ldots \ldots \ldots \ldots \ldots$ & 0.092 & Metric tons per mile of distribution pipeline & EIA Estimate ${ }^{a}$ \\
\hline System Upsets $\ldots \ldots \ldots \ldots \ldots \ldots \ldots$. . . . . . & 0.031 & Metric tons per mile of distribution pipeline & EPA, $1993^{b}$ \\
\hline \multicolumn{4}{|l|}{ Oil Refineries } \\
\hline Fugitive Emissions ... & $1.635 \times 10^{-5}$ & Short tons per barrel of refinery capacity & Radian, $1992^{c}$ \\
\hline Tank Farms $\ldots \ldots \ldots \ldots$ & $4.37 \times 10^{-7}$ & Short tons per barrel of throughput & Radian, $1992^{c}$ \\
\hline Flaring $\ldots \ldots \ldots \ldots \ldots \ldots \ldots$ & $4.00 \times 10^{-7}$ & Short tons per barrel of refinery capacity & Radian, $1992^{c}$ \\
\hline Crude Transportation (Marine) $\ldots \ldots \ldots \ldots \ldots$ & $2.55 \times 10^{-6}$ & Short tons per barrel loaded & Radian, $1992^{c}$ \\
\hline
\end{tabular}

${ }^{2}$ EIA estimate based on scaling of factors published in U.S. Environmental Protection Agency, Anthropogenic Methane Emissions in the United States-Estimates for 1990, Report to Congress (Washington, DC, April 1993).

bU.S. Environmental Protection Agency, Office of Air and Radiation, Anthropogenic Methane Emissions in the United States-Estimates for 1990, Report to Congress (Washington, DC, Apri 1993).

${ }^{\mathrm{c}}$ Radian Comoration, Global Emissions of Methane from Petroleum Sources, Final Report Prepared for the American Petroleum Institute (Research Triangle Park, NC, February 1992). 
Table C10. U.S. Solid Waste Landfilled, 1983-1994

(Million Metric Tons)

\begin{tabular}{|c|c|c|c|c|c|c|c|c|c|c|c|c|}
\hline Item & 1983 & 1984 & 1985 & 1986 & 1987 & 1988 & 1989 & 1990 & 1991 & 1992 & 1993 & P1994 \\
\hline Waste Landfilled & 187.0 & 192.9 & 192.1 & 197.8 & 205.0 & 208.5 & 209.5 & 210.6 & 190.3 & 170.0 & 167.5 & NA \\
\hline Total Wasle in Place & $5,323.4$ & $5,516.2$ & $5,708.3$ & $5,906.2$ & $6,111.2$ & $6,319.7$ & $6,529.1$ & $6,739.7$ & $6,930.0$ & $7,100.0$ & $7,267.6$ & NA \\
\hline
\end{tabular}

NA $=$ not available.

Sources: Municipal solid waste landfilled from Franklin Associates, Ltd., Characterization of Municipal Solid Waste in the United States, Worksheets, 1992 Update (prepared for the U.S. Environmental Protection Agency, Municipal Solid and Industrial Solid Waste Division, July 1992), Personal communication with Marjorie Franklin, Franklin Associates, Ltd., May 1994, and Biocycle, Nationwide Survey: The State of Garbage in America 1988-1994. Total MSW in place from estimates documented in Chapter 3.

Table C11. Factors Used To Estimate Methane and Nitrous Oxide Emissions from Burning of Crop Residues

\begin{tabular}{|c|c|c|c|c|}
\hline Crop Type & $\begin{array}{c}\text { Ratio of Residue to } \\
\text { Crop Volume }\end{array}$ & $\begin{array}{c}\text { Dry Matter Content } \\
\text { (Percent) }\end{array}$ & $\begin{array}{c}\text { Carbon Content } \\
\text { (Percent) }\end{array}$ & $\begin{array}{c}\text { Nitrogen Content } \\
\text { (Percent) }\end{array}$ \\
\hline Barley .......... & 1.2 & 85.0 & 45.7 & 0.43 \\
\hline Beans $\ldots \ldots \ldots \ldots$ & 2.1 & 85.4 & $c_{45.0}$ & $a_{2.30}$ \\
\hline Corn $\ldots \ldots \ldots \ldots$ & 1.0 & 78.0 & 47.1 & 0.81 \\
\hline Oats ........... & 1.3 & $b_{90.1}$ & $a_{42.0}$ & ${ }^{a} 0.84$ \\
\hline Peas $\ldots \ldots \ldots \ldots$ & 1.5 & ${ }^{b} 90.2$ & $c_{45.0}$ & $c_{2.30}$ \\
\hline Peanuts . . . . . . . & 1.0 & 90.1 & $c_{42.3}$ & $c_{1.10}$ \\
\hline Potatoes . . . . . . . . & 0.4 & ${ }^{c} 86.7$ & 42.3 & 1.10 \\
\hline Rice ... . . . . . . . . & 1.4 & 85.0 & 41.4 & 0.67 \\
\hline Rye $\ldots \ldots \ldots \ldots$ & 1.6 & $c_{90.0}$ & $c_{48.5}$ & ${ }^{c} 0.70$ \\
\hline Sorghum $\ldots \ldots \ldots$ & 1.4 & 88.0 & $a_{34.0}$ & do.85 \\
\hline Soybeans . . . . . . & 2.1 & 86.7 & ${ }^{a} 44.0$ & $d_{2.30}$ \\
\hline Sugar Beets . . . . . . & 0.2 & $c_{90.0}$ & 40.7 & 2.28 \\
\hline Sugar Cane . . . . . . & 1.2 & 37.2 & 47.0 & 0.19 \\
\hline Wheat $\ldots \ldots \ldots \ldots$ & 1.3 & 85.0 & 48.5 & 0.28 \\
\hline
\end{tabular}

Sources: A. Strehler and W. Stutzle, "Biomass Residues," in D. Hall and R. Overend (eds.), Biomass: Regenerable Energy (Chichester, UK: John Wiley and Sons, 1987), except where indicated by: (a) C. Li, S. Frolking, and R. Harriss, "Modeling Carbon Biogeochemistry in Agricultural Soils," Global Biogeochemical Cycles, Vol. 8 (September 1994); (b) E. Darley, Emission Factors From Burning Agricultural Wastes Collected in California, Final Report, CALARB Project 4-011 (Riverside, CA: University of California, 1977); (c) U.S. Environmental Protection Agency, Office of Policy, Planning and Evaluation, Inventory of U.S. Greenhouse Gas Emissions and Sinks: 1990-1993, EPA 230-R-94-014 (Washington, DC, September 1994); (d) G. Barnard, "Use of Agricultural Residues as Fuel," in J. Pasztor and L. Kristoferson (eds.), Bioenergy and the Environment (Boulder, CO: Westview Press, 1990).

Table C12. Average Pre-Slaughter Live Weights for U.S. Cattle and Calves, 1984-1994 (Pounds)

\begin{tabular}{|c|c|c|c|c|c|c|c|c|c|c|c|}
\hline Animal Class & 1984 & 1985 & 1986 & 1987 & 1988 & 1989 & 1990 & 1991 & 1992 & 1993 & 1994 \\
\hline Cattle $\ldots \ldots \ldots \ldots \ldots$ & 1,067 & 1,098 & 1,101 & 1,105 & 1,120 & 1,134 & 1,136 & 1,163 & 1,169 & 1,161 & 1,189 \\
\hline Calves .............. & 230 & 234 & 239 & 239 & 252 & 260 & 281 & 346 & 376 & 388 & 384 \\
\hline
\end{tabular}

Source: U.S. Department of Agricullure, Internet Site @gopher.usda.mannlib.comell.edu. 


$$
\text { - - ב }
$$




\section{Appendix D \\ Emission Sources Excluded}

Certain sources of greenhouse gas emissions are not included in the estimates presented in the main body of this report. These omissions have been deemed necessary due to lack of necessary data, highly speculative estimation methods, or classification as a "natural" source.

\section{Biofuel Combustion}

The carbon found in biofuels is the result of atmospheric uptake. During combustion of biofuels, there is an immediate release of this carbon in the form of carbon dioxide. As part of the natural carbon cycle, however, these carbon emissions are reabsorbed over time. Since they produce no net change in the overall carbon budget, such emissions are not included in this report. If the initial flux had been counted, annual carbon dioxide emissions estimates would have been approximately 45 million metric tons higher than reported in Chapter 2 (Table D1).

Emissions are estimated by multiplying EIA energy consumption data for biofuels by the applicable emissions factors. The EIA data used for municipal solid waste include methane recovery from landfills, but since the methane is not used as a biofuel, it has been subtracted for these calculations. Carbon dioxide emissions factors for combustion of wood fuels and municipal solid waste are taken from the EIA report, Electric
Power Annual $19933^{213}$ The emissions coefficient for alcohol fuels, 19.67 million metric tons of carbon per quadrillion Btu, was derived specifically for use in this report.

\section{Overseas U.S. Military Oil Consumption}

Domestic military energy consumption is incorporated into U.S. energy statistics. However, energy consumption for overseas operations is a more complex issue. The data can either be reported in the national energy statistics of the host country or included in U.S. export statistics if domestic oil is transported to ships and other facilities. In some circumstances, the oil consumption may go unreported.

Estimating, even roughly, the quantity of oil consumed for overseas military operations is an uncertain procedure. The Defense Fuel Supply Center reports that petroleum sales for 1994 totaled 122.4 million barrels. Of this, approximately 74 percent was acquired domestically, and is assumed to be included in U.S. statistics. A reasonable estimate of military oil consumption not reported elsewhere would, therefore, be 26 percent of total military consumption of jet fuel, middle distillates, and residual oil. ${ }^{214}$ Using this method, emissions for 1994 are estimated at 3.51 million metric tons of carbon (Table D2).

Table D1. Estimated U.S. Carbon Dioxide Emissions from Biofuels, 1987-1994 (Million Metric Tons of Carbon)

\begin{tabular}{|c|c|c|c|c|c|c|c|c|}
\hline Fuel & 1987 & 1988 & 1989 & 1990 & 1991 & 1992 & 1993 & P1994 \\
\hline Alcohol Fuel & 1.36 & 1.38 & 1.40 & 1.61 & 1.34 & 1.63 & 1.73 & 1.89 \\
\hline Total $\ldots \ldots \ldots \ldots \ldots$ & 45.63 & 47.39 & 47.39 & 44.04 & 44.28 & 46.79 & 46.04 & 47.09 \\
\hline
\end{tabular}

$\mathrm{P}=$ preliminary data.

Note: Data in this table are revised from the data contained in the previous EIA report, Emissions of Greenhouse Gases in the United States 1987-1992, DOE/EIA-0573 (Washington, DC, November 1994).

Sources: Underlying energy data from Energy Information Administration, Annual Energy Review 1994, DOE/ElA-0384(94) (Washington, DC, July 1995), Table 10.2. Emissions coefficients for municipal solid waste combustion and wood and wood waste from Energy Information Administration, Electric Power Annual 1993, DOE/EIA-0348(93) (Washington, DC, 1994), Table C3.

${ }^{213}$ Energy Information Administration, Electric Power Annual 1993, DOE/EIA-0348(93) (Washington, DC, December 1994).

${ }^{214} \mathrm{G}$ asoline is presumably acquired for motor vehicles and, typically, is accounted for in both domestic and foreign energy statistics. 
Table D2. Estimated Carbon Emissions from U.S. Military Operations Abroad, 1987-1994

(Million Metric Tons of Carbon)

\begin{tabular}{c|c|c|c|c|c|c|c|c}
\hline Item & 1987 & 1988 & 1989 & 1990 & 1991 & 1992 & 1993 & 1994 \\
\hline Energy Consumption (Quadrillion Btu) $\ldots$ & 0.29 & 0.31 & 0.26 & 0.25 & 0.30 & 0.12 & 0.20 & 0.18 \\
Carbon Emissions . . . . . . . . . . . & 5.72 & 5.99 & 4.98 & 4.85 & 5.86 & 2.26 & 3.81 & 3.51 \\
\hline
\end{tabular}

Sources: Energy consumption from Defense Fuel Supply Center, Fact Book (various years). Data converted from fiscal years in source publication into calendar years by weighted average. Carbon emissions from EIA estimates presented in this chapter.

\section{Forest Fires}

Forest fires are known to create greenhouse gas fluxes within the atmosphere over extensive time periods. Specifically, forest fires produce carbon dioxide, methane, and nitrous oxide. Due to carbon uptake that occurs with subsequent regrowth (assumed to balance out the initial carbon flux) and the inability to distinguish emissions from natural versus humaninduced fires, estimates from this source are not included in this report.

\section{Carbon Dioxide Coproduction With Natural Gas}

The carbon dioxide content of natural gas varies by reservoir. Marketed natural gas, however, must consist largely of methane. When natural gas direct from the reservoir does not meet marketable standards, it is treated in a gas processing plant. During treatment, impurities and heavy hydrocarbons are removed from the gas. Excess carbon dioxide is one of the separated compounds, and it is either used industrially (estimates provided in Chapter 2) or vented to the atmosphere.

The EIA reports that 413 billion cubic feet of nonhydrocarbon gases were removed from total natural gas production in 1993. This figure does not take into account the 11 (out of 33) gas-producing States that do not report annual amounts of nonhydrocarbon gases removed. ${ }^{215}$ In its reporting, Texas quantifies commercial carbon dioxide recovery from gas plants. From those data, the EIA is able to make rough estimates of carbon dioxide recovery in other States (Table D3).

In Texas, the amount of nonhydrocarbon gas removed is approximately 2 percent of gross natural gas production. This same ratio is applied to gross production for the nonreporting States. Similarly, the ratio of commercial carbon dioxide production to nonhydrocarbon gas removal in Texas (roughly 90 percent) is applied to other States to determine the total amount of carbon dioxide removed from gas plants in the United States. In order to avoid double-counting with industrial carbon dioxide production, the commercial recovery in Texas is deducted from this total. Any commercial recovery in other States is double-counted; however, due to the lack of data, this is currently unavoidable.

In 1993, carbon dioxide coproduction at natural gas plants was estimated at 5 million metric tons of carbon. Because of its speculative nature, this estimate is not included in the main body of the report. First, there is no basis to support the assumption that the ratios applicable to Texas are generalizable across the country. Second, there is no basis for determining the precise amount of carbon dioxide recovered for commercial use in States other than Texas.

\section{Fermentation}

During the fermentation process, complex organic compounds are split through a variety of chemical reactions. The most common is the anaerobic conversion of sugar into carbon dioxide and alcohol. Fermentation does not create a net flux of emissions, however, because the carbon dioxide produced is reused in the process.

\section{Enhanced Oil Recovery}

As a replacement for natural gas, carbon dioxide is being injected into reservoirs for the purpose of retrieving additional oil. Over time, the carbon dioxide seeps into the producing well, creating a mixture of oil, natural gas, and carbon dioxide. If the energy content

\footnotetext{
${ }^{215}$ Energy Information Administration, Natural Gas Annual 1993, DOE/EIA-0131(93) (Washington, DC, October 1994), p. 4. The 11 nonreporting States account for approximately 40 percent of domestic gas production.
} 
Table D3. Estimated U.S. Carbon Dioxide Emissions from Natural Gas Plants, 1987-1994

(Billion Cubic Feet, Unless Otherwise Noted)

\begin{tabular}{|c|c|c|c|c|c|c|c|c|}
\hline Item & 1987 & 1988 & 1989 & 1990 & 1991 & 1992 & 1993 & 1994 \\
\hline Total Gross Withdrawals & $20,055.8$ & $20,880.2$ & $20,998.8$ & $21,490.5$ & $21,740.2$ & $22,132.2$ & $22,912.0$ & NA \\
\hline States Reporting NHCGR ${ }^{a}$ & $4,904.2$ & $5,028.3$ & $5,155.8$ & $5,417.2$ & $5,941.8$ & $6,670.4$ & $7,019.8$ & NA \\
\hline Texas ......... & $6,687.7$ & $6,918.6$ & $6,881.0$ & $6,907.1$ & $6,898.9$ & $6,708.0$ & $6,816.9$ & NA \\
\hline All Other States & $8,463.9$ & $8,933.3$ & $8,962.0$ & $9,166.2$ & $8,899.6$ & $8,753.9$ & $9,075.3$ & NA \\
\hline Estimated NHCGR . . . . . & 545.3 & 638.5 & 541.7 & 472.7 & 453.8 & 455.4 & 595.5 & NA \\
\hline States Reporting NHCGR & 250.2 & 315.7 & 203.3 & 133.7 & 102.4 & 100.4 & 229.7 & NA \\
\hline Texas & 125.8 & 144.1 & 159.1 & 155.6 & 173.4 & 180.0 & 184.3 & NA \\
\hline All Other States ${ }^{b}$ & 169.3 & 178.7 & 179.2 & 183.3 & 178.0 & 175.1 & 181.5 & NA \\
\hline Estimated $\mathrm{CO}_{2}$ Removed ${ }^{c}$ & 490.8 & 574.7 & 487.5 & 425.4 & 408.4 & 409.9 & 535.9 & NA \\
\hline Estimated $\mathrm{CO}_{2}$ Recovered $\ldots$. & 69.1 & 109.2 & 135.5 & 148.9 & 133.5 & 176.7 & 186.3 & NA \\
\hline States Reporting NHCGR & 0.0 & 0.0 & 0.0 & 0.0 & 0.0 & 0.0 & 0.0 & NA \\
\hline Texas $\ldots . . . . . .$. & 69.1 & 109.2 & 135.5 & 148.9 & 133.5 & 176.7 & 186.3 & NA \\
\hline All Other States ...... & 0.0 & 0.0 & 0.0 & 0.0 & 0.0 & 0.0 & 0.0 & NA \\
\hline \multicolumn{9}{|l|}{ Estimated $\mathrm{CO}_{2}$ Emissions } \\
\hline Billion Cubic Feet . & 421.7 & 465.5 & 352.0 & 276.6 & 274.9 & 233.2 & 349.6 & NA \\
\hline Million Metric Tons $\mathrm{CO}_{2}$ & 22.2 & 24.5 & 18.5 & 14.6 & 14.5 & 12.3 & 18.4 & NA \\
\hline Million Metric Tons Carbon & 6.1 & 6.7 & 5.1 & 4.0 & 3.9 & 3.4 & 5.0 & NA \\
\hline
\end{tabular}

a Nonhydrocarbon gases removed.

${ }^{b}$ Assumes that 2 percent of All Other States' gas withdrawals are nonhydrocarbon gases.

cAssumes that 90 percent of the total nonhydrocarbon gas removed is carbon dioxide.

Note: Totals may not equal sum of components due to independent rounding.

Sources: Railroad Commission of Texas, Annual Summaries of Texas Natural Gas (various years), and Energy Information Administration, Natural Gas Annual, DOE/EIA-0131 (various years).

is sufficiently high, the gaseous portion of this mix will probably be sent to a gas plant. However, if the energy content is low, the gas is likely to be vented or flared. At this time, there is no basis for the EIA to estimate the quantity of added carbon dioxide that is vented or flared. However, the annual amount of carbon dioxide used for enhanced oil recovery is probably on the order of 12 million metric tons. ${ }^{216}$ Emissions are, therefore, some fraction of that figure.

\section{Lead Smelting}

Smelting of lead includes a stage in which limestone undergoes calcination. As described in Chapter 2, carbon dioxide is released as a byproduct of the calcination reaction. Emissions estimates cannot be calculated for this report because there are no known statistics regarding the amount of limestone used in lead smelting. The EIA is currently researching alternative data sources in an effort to include estimates of these emissions in future reports.

\section{Waste Treatment and Incineration}

Wastewater treatment produces methane emissions when the organic content is decomposed anaerobically. According to the IPCC, developed countries such as the United States typically use aerobic treatments, reducing the potential for methane emissions. The EPA estimates that municipal wastewater treatment in the United States may create an annual flux of 150,000 metric tons of methane. ${ }^{217}$ At this time, no data are available to estimate emissions from industrial wastewater treatment facilities. Additionally, recent studies in Japan, Belgium, and Norway indicate that incineration of waste produces nitrous oxide. Methods for estimating

\footnotetext{
${ }^{216}$ The U.S. Department of Commerce reports total sales of industrial carbon dioxide at approximately 17 million metric tons annually, while Freedonia Group, Inc., reports that approximately 5 million metric tons are used for purposes other than enhanced oil recovery.

${ }^{217}$ U.S. Environmental Protection Agency, Office of Policy, Planning and Evaluation, Inventory of U.S. Greenhouse Gas Emissions and Sinks: 1990-1993, EPA 230-R-94-014 (Washington, DC, September 1994), p. 72.
} 
emissions from this source remain highly uncertain, and the IPCC maintains that actual emissions are minor. When necessary data become available and methods are clarified, the EIA intends to present estimates of emissions from waste treatment and incineration in this report.

\section{Abandoned Coal Mines}

As noted in Chapter 3, recent research indicates that a sample of 30 abandoned coal mines collectively emitted some 25,000 metric tons of methane in 1994, arid the researchers believe, extrapolating from the sample, that national-level emissions from this source may be as high as 300,000 metric tons. ${ }^{218}$ As more research is published, particularly on extrapolating the sample into national-level emissions, this source will probably be included in future reports.

\section{Shale Oil Plants}

Synthetic crude oil can be produced by thermally decomposing shale oil in a large-scale retort. To provide the required heat, residual hydrocarbons in the waste shale are burned, creating carbon emissions. The only commissioned U.S. shale oil plant was operated by the Unocal Corporation from 1985 to 1990 . During that time, 4.6 million barrels of synthetic crude were produced. In its last and most productive year, this plant may have emitted 50,000 metric tons of carbon. ${ }^{219}$

\section{Geothermal Steam}

Geothermally pressurized steam can be sent through a turbine to generate electricity. Frequently, the steam contains some quantity of dissolved carbon dioxide. After the steam has passed through the turbine, it condenses into water, and any carbon dioxide is released to the atmosphere. Currently, there are no data to link carbon dioxide content with specific sites and production. However, it is known that at the principal geothermal site in the United States (the Geysers, near Guerneyville, CA), the steam has a relatively high concentration of dissolved carbon dioxide. If all geothermal power in the United States were generated at the Geysers, carbon emissions would have been approximately 53,000 metric tons in $1993 .{ }^{220}$ If better documentation becomes available in the future, estimates from this minor source of emissions will be incorporated into the report.

\footnotetext{
${ }^{218}$ S.D. Piccot, S.S. Masemore, E. Ringler, and D.A. Kirchgessner, "Developing Improved Methane Emission Estimates for Coal Mining Operations," Presented at the 1995 Greenhouse Gas Emissions and Mitigation Research Symposium (U.S. Environmental Protection Agency, June 27-29, 1995).

${ }^{219}$ This calculation is based on information about the shale oil processing from the U.S. Department of Energy, Energy Technology Characterizations Handbook: Environmental Pollution and Control Factors, Third Edition, DOE/EP-0093 (Washington, DC, March 1983), pp. 32-39, which suggests roughly 70 percent thermal efficiency.

${ }^{220}$ U.S. Department of Energy, Energy Technology Characterizations Handbook: Environmental Pollution and Control Factors, Third Edition, DOE/EP-0093 (Washington, DC, March 1983), pp. 188-189.
} 


\section{Appendix E \\ Common Conversion Fagtors}

\section{Permutations of SI Units}

$1 \mathrm{gC}=1$ gram carbon (C)

$1 \mathrm{GgC}=$ gigagram carbon $(\mathrm{C})=1,000$ metric tons carbon $(C)$

$1 \mathrm{TgC}=1$ teragram carbon $(C)=1$ million metric tons carbon (C)

$1 \mathrm{PgC}=1$ petagram carbon $(C)=1$ billion metric tons carbon $(C)$

$1 \mathrm{ppmv}=1$ part per million by volume in the atmosphere

$1 \mathrm{ppbv}=1$ part per billion by volume in the atmosphere

1 pptv = 1 part per trillion by volume in the atmosphere

\section{Density}

1 thousand cubic feet of methane $=42.28$ pounds

1 thousand cubic feet carbon dioxide $=115.97$ pounds

1 metric ton natural gas liquids $=11.6$ barrels

1 metric ton unfinished oils $=7.46$ barrels

1 metric ton alcohol $=7.94$ barrels

1 metric ton liquefied petroleum gas $=11.6$ barrels

1 metric ton aviation gasoline $=8.9$ barrels

1 metric ton naphtha jet fuel $=8.27$ barrels

1 metric ton kerosene jet fuel $=7.93$ barrels

1 metric ton motor gasoline $=8.53$ barrels

1 metric ton kerosene $=7.73$ barrels

1 metric ton naphtha $=8.22$ barrels

1 metric ton distillate $=7.46$ barrels

1 metric ton residual oil $=6.66$ barrels

1 metric ton lubricants $=7.06$ barrels

1 metric ton bitumen $=6.06$ barrels

1 metric ton waxes $=7.87$ barrels

1 metric ton petroleum coke $=5.51$ barrels

1 metric ton petrochemical feedstocks $=7.46$ barrels

1 metric ton special naphtha $=8.53$ barrels

1 metric ton miscellaneous products $=8.00$ barrels

\section{Alťernative Measures of Greenhouse Gases}

1 pound methane, measured in carbon units $\left(\mathrm{CH}_{4}-\mathrm{C}\right)$ $=1.333$ pounds methane, measured at full molecular weight $\left(\mathrm{CH}_{4}\right)$

1 pound carbon dioxide, measured in carbon units $\left(\mathrm{CO}_{2}-\mathrm{C}\right)=3.6667$ pounds carbon dioxide, measured at full molecular weight $\left(\mathrm{CO}_{2}\right)$

1 pound carbon monoxide, measured in carbon units $(\mathrm{CO}-\mathrm{C})=2.333$ pounds carbon monoxide, measured at full molecular weight $(\mathrm{CO})$

1 pound nitrous oxide, measured in nitrogen units $\left(\mathrm{N}_{2} \mathrm{O}-\mathrm{N}\right)=1.571$ pounds nitrous oxide, measured at full molecular weight $\left(\mathrm{N}_{2} \mathrm{O}\right)$

\section{Weight}

1 kilogram $=2.205$ pounds

1 short ton $=0.9072$ metric tons

1 metric ton $=1.1023$ short tons $=2,204.6$ pounds

1 cubic meter $=35.3147$ cubic feet

1 cubic centimeter $=3.531 \times 10^{-5}$ cubic feet

\section{Area}

1 acre $=0.40468724$ hectare $($ ha $)=4,047 \mathrm{~m}^{2}$

1 hectare $(\mathrm{ha})=10,000 \mathrm{~m}^{2}=2.47$ acres

1 kilometer $=0.6214$ miles

\section{Energy}

1 joule $=947.9 \times 10^{-21}$ quadrillion Btu 1 exajoule $=10^{18}$ joules $=0.9479$ quadrillion Btu

1 quadrillion $\mathrm{Btu}=1.0551$ exajoule 
C.

$\ldots$

. 


\section{References}

Abrahamson, D. "Aluminum and Global Warming." Nature 356. (April 1992.) 454.

Albritton, D.L., et al. "Trace Gas Radiative Forcing Indices." Climate Change 1994 Ed. J.T. Houghton et al. (Cambridge, UK: Cambridge Unversity Press, 1995.) 222.

Alternative Fluorocarbons Environmental Acceptability Study. Historic Production, Sales, and Atmospheric Release of HCFC-142b. (Washington, DC, February 1994.)

Alternative Fluorocarbons Environmental Acceptability Study. Production, Sales and Atmospheric Release of CFC113, CFC-114, CFC-115, CFC-11, and CFC-12 Through 1991. (Mimeo, Washington, DC, September 1992.)

Alternative Fluorocarbons Environmental Acceptability Study. Production, Sales and Atmospheric Release of Fluorocarbons Through 1992. (Washington, DC, August 1993.)

Alternative Fluorocarbons Environmental Acceptability Study. Production, Sales and Atmospheric Release of Fluorocarbons Through 1993. (Washington, DC, March 1995.)

American Automobile Manufacturers Association. Motor Vehicle Facts and Figures. (Detroit, MI, 1993.)

American Automobile Manufacturers Association. AAMA Vehicle Facts and Figures. (Detroit, MI, 1994.)

American Gas Association. Gas Engineers Handbook: Fuel Gas Engineering Practices. (New York, NY: Industrial Press, 1974.)

American Gas Association. Gas Facts. Annual Statistical Report. (Washington, DC, various years.)

American Iron and Steel Institute. Iron and Steel Annual Statistical Report. (Washington, DC, various years.)

American Petroleum Institute. Basic Petroleum Data Book. (Washington, $D C$, various years.)

American Society of Agricultural Engineers. Manure Production and Characteristics Standards. (St. Joseph, MI, 1988.)

American Society for Testing and Materials. ASTM and Other Specifications for Petroleum Products and Lubricants. (Philadelphia, PA, 1985.)
Andrae, M.O., et al. "Biomass Burning Emissions and Associated Haze Layers over Amazonia." Journal of Geophysical Research 93. (1988.) 1509-1527.

Augenstein, D. "The Greenhouse Effect and U.S. Landfill Methane." Global Environmental Change. (December 1992.) 311-328.

Baldwin, R.L., Thornley, J.H.M., and Beever, D.E. "Metabolism of the Lactating Cow: Digestive Elements of a Mechanistic Model." Journal of Dairy Research 54. (1987.) 107-131.

Barnard, G. "Use of Agricultural Residues as Fuel." Bioenergy and the Environment Ed. J. Pasztor and L. Kristoferson. (Boulder, CO: Westview Press, 1990.)

Barnes, D.W., and Edmonds, J.A. An Evaluation of the Relationship Between the Production and Use of Energy and Atmospheric Methane Emissions. DOE/NBB-0088P. (Washington, DC, U.S. Department of Energy, 1990.)

Bartlett, K., and Harriss, R.C. "Review and Assessment of Methane Emissions from Wetlands." Chemosphere 26. (1993.) 272-276.

Bell, J.F., and Linden, H.R. In American Gas Association, Gas Engineers Handbook (New York, NY: Industrial Press, 1974.)

Berdowski, J.J.M., Beck, L., Piccot, S., Olivier, G.J., and Veldt, C. "Working Group Report: Methane Emissions from Fuel Combustion and Industrial Processes." Proceeding of an International IPCC Workshop on Methane and Nitrous Oxide: Methods in National Emissions Inventories and Options for Control. Ed. A.R. van Amstel. RIVM Report no. 481507003. (Bilthoven, The Netherlands, 1993.) 136.

Bingemer, H.G., and Crutzen, P.J. "The Production of Methane From Solid Wastes." Journal of Geophysical Research 92, D2. (February 20, 1987.) 2181-2187.

Biocycle, "Nationwide Survey: The State of Garbage in America." (Various years.)

Birdsey, R.A. Carbon Storage and Accumulation in United States Forest Ecosystems. U.S. Forest Service General Technical Report WO-59. (Washington, DC, 1992.)

Blaxter, K.L., and Clapperton, J.L. "Prediction of the Amount of Methane Produced by Ruminants." British Journal of Nutrition 19. (1965.) 511-522. 
Bodanzky, D. "Prologue to the Climate Convention." Negotiating Climate Change: The Inside Story of the Rio Convention Ed. I. Minter and J.A. Leonard. (Cambridge, UK: Cambridge University Press, 1994.) 49-66.

Boden, T.A., Stepanski, R.J., and Stoss, F.W. Trends '91: A Compendium of Data on Global Change. ORNL/CDIAC46. (Oak Ridge, TN: Oak Ridge National Laboratory, December 1991.) 379-429.

Bogner, J.E. "Anaerobic Burial of Refuse in Landfills: Increased Atmospheric Methane and Implications for Increased Carbon Storage." Ecological Bulletins 42. (1992.) 98-108.

Bouwman, A.F. "Exchange of Greenhouse Gases Between Terrestrial Ecosystems and Atmosphere." Soils and the Greenhouse Effect. Ed. A.F. Bouwman. (New York, NY: John Wiley and Sons, 1990.) 61-127.

Boyer, C.M. "International Update: Coalbed Methane in China." Presented at the Spring 1995 Session of the North American Coalbed Methane Forum (April 12-13, 1995.)

Bremner, J.M., and Blackmer, A.M. "Nitrous Oxide: Emissions from Soil during Nitrification of Fertilizer Nitrogen." Science 199. (1978.) 295-296.

Burdick, D.L., and Leffler, W.L. Petrochemicals in Nontechnical Language. (Pennwell Publishing Company, 1990.)

Carbon Dioxide Information Analysis Center, Oak Ridge National Laboratory, Trends '91: A Compendium of Data on Global Change, ORNL/CDIAC-46. (Oak Ridge, TN, December 1991.) 339-363.

Chemical and Engineering News. Annual report on "Top 50 Industrial Chemicals." (April issue, various years.)

Chemical Manufacturers Association, Inc. U.S. Chemical Industry Statistical Handbook. (Washington, DC, various years.)

Chen, Y.R. "Kinetic Analysis of Anaerobic Digestion of Pig Manure and its Implications." Agricultural Wastes 8. (1983.) 65-81.

Cicerone, R., and Oremland, R. "Biogeochemical Aspects of Atmospheric Methane." Global Biochemical Cycles 2. (1988.) 299-327.

Cicerone, R.J., and Shetter, J.D. "Seasonal Variation of Methane Flux from a California Rice Paddy." Journal of Geophysical Research 88, C15. (December 1983.) 11,02211,024 .

Cicerone, R.J., and Shetter, J.D. "Sources of Atmospheric Methane: Measurements in Rice Paddies and Discussion." Journal of Geophysical Research 86, C8. (August 1981.) $7,203-7,209$.
Cicerone, R.J., Shetter, J.D., and Delwiche, C.C. "Seasonal Variation of Methane Flux from a California Rice Paddy." Journal of Geophysical Research 88. (1983.) 72037209.

Clean Air Act Amendments of 1990. (P.L. 101-549, Nov. 15, 1990), Title VI, "Stratospheric Ozone Protection," 10489AT2849-2872.

Clinton, W.J., and Gore, A. The President's Climate Change Action Plan. (Washington, DC, October 1994.) Available through the U.S. Department of Energy Office of Public Information.

Council for Agricultural Science and Technology. Preparing U.S. Agriculture for Global Climate Change, Task Force Report No. 119. (Ames, IA, 1992.) 96.

Crutzen, P.J., Aselmann, I., and Seiler, W. "Methane Production by Domestic Animals, Wild Ruminants, Other Herbivorous Fauna, and Humans." Tellus 38B, 34. (1986.) 271-284.

Cubbage, F.C. "Federal Land Conversion Programs." Forests and Global Change, Vol. 1. (Washington, DC, 1992.) 184.

Dahl, T. Wetlands Losses in the United States: 1780's to 1980's. (Washington, DC, U.S. Department of the Interior, Fish and Wildlife Service, 1990.)

Dale, C., et al. "First Oxygenated Gasoline Season Shakes Out Differently Than Expected." Oil and Gas Journal. (October 25, 1993.)

Darley, E. Emission Factors From Burning Agricultural Wastes Collected in California. Final Report, CAL/ARB Project 4-011. (Riverside, CA: University of California, 1977.)

Daugherty, A. Major Uses of Land in the United States: 1987. Agricultural Economic Report No. 643. (Washington, DC, U.S. Department of Agriculture, Economic Research Service, 1991.)

Daugherty, A. Major Uses of Land in the United States: 1992. Unpublished review draft. (1995.)

Davis, S.C., and Strang, S.G. Transportation Energy Data Book: Edition 13, ORNL-6743. (Oak Ridge, TN: Oak Ridge National Laboratory, Center for Transportation Analysis, March 1993.)

Davis, S.C., and Strang, S.G. Transportation Energy Data Book: Edition 14. ORNL-6743. (Oak Ridge, TN: Oak Ridge National Laboratory, Center for Transportation Analysis, March 1994.)

Defense Logistics Agency, Defense Fuel Supply Center, Office of the Comptroller. Fact Book Annual Report. (Alexandria, VA, various years.) 
DeLuchi, M. Emissions of Greenhouse Gases from the Use of Transportation Fuels and Electricity. Vol. 2. ANL/ ESD/TM-22. (Chicago, IL: Argonne National Laboratory, November 1993.)

De Soete, G.G. "Nitrous Oxide from Combustion and Industry: Chemistry, Emissions and Control." International IPCC Workshop Proceedings: Methane and Nitrous Oxide, Methods in National Emissions Inventories and Options for Control. Ed. A.R. van Amstel. (Bilthoven, Netherlands: RIVM, 1993.) 287-337.

Diamond, W.P., LaScola, J.C., and Hyman, D.M. "Results of the Direct Method Determination of the Gas Content of U.S. Coalbeds." U.S. Bureau of Mines Circular 9067. (1986.) $96 \mathrm{pp}$.

Dickson, C. Aviation Turbine Fuels, 1992. NIPER-179 PPS93/2. (Bartlesville, OK: National Institute for Petroleum and Energy Research, March 1993.)

Dlugokencky, E.J., Lang, P.M., Massarie, K.A., and Steel, L.P. "Atmospheric $\mathrm{CH}_{4}$ Records from Sites in the NOAA/CMDL Air Sampling Network." Trends '93: A Compendium of Data on Global Change. Ed. T.A. Boden, D.P. Kaiser, R.J. Stepanski, and F.W. Stoss. ORNL/ CDIAC-65. (Oak Ridge, TN: Carbon Dioxide Information Analysis Center, Oak Ridge National Laboratory, 1994.) 50-126.

Douglas, H. Handbook of Mineral Economics. (San Francisco, CA: Hugh Douglas and Company, 1983.) 46.

Duxbury, J.M., and McConnaughey. P.K. "Effect of Fertilizer Source on Denitrification and Nitrous Oxide Emission in A Maize Field." Soil Sci. Soc. Am. J. 50. (1986.) 644-648.

E.H. Pecham and Associates, Inc. Analysis and Comparison of Four California Greenhouse Gas Emission Inventories. Report prepared for the U.S. Environmental Protection Agency, Office of Policy, Planning, and Evaluation. (Rancho Cordova, CA, April 1993.)

Eberle, A.C. "An Engineering Estimate of the Incremental Change in Methane Emissions with Increasing Throughput in a Natural Gas System." Presented at the 1994 International Workshop on Environmental and Economic Impacts of Natural Gas Losses, March 22 and 23, 1994, Prague, The Czech Republic.

Eichner, M. "Nitrous Oxide Emissions from Fertilized Soils: Summary of Available Data." Journal of Environmental Quality 19. (1990.) 272-280.

Energy Information Administration. Annual Energy Review. DOE/EIA-0384. (Washington, DC, various years.)
Energy Information Administration. Btu Tax on Finished Petroleum Products. Unpublished Report. (Washington, DC, April 1993.)

Energy Information Administration. Coal Industry Annual 1993. DOE/EIA-0584(93). (Washington, DC, December 1994.)

Energy Information Administration. Coal Production. DOE/EIA-0118. (Washington, DC, various years.)

Energy Information Administration. Cost and Quality of Fuels for Electric Utility Plants 1991. DOE/EIA-0191(91). (Washington, DC, August 1992.)

Energy Information Administration. Electric Power Annual. DOE/EIA-0348. (Washington, DC, various years.)

Energy Information Administration. Emissions of Greenhouse Gases in the United States 1985-1990. DOE/EIA0573. (Washington, DC, September 1993.)

Energy Information Administration. Emissions of Greenhouse Gases in the United States 1987-1992. DOE/EIA0573. (Washington, DC, November 1994.)

Energy Information Administration. Estimates of U.S. Biomass Energy Consumption 1992. DOE/EIA-0548(92). (Washington, DC, May 1994.)

Energy Information Administration. Fuel Oil and Kerosene Sales. DOE/EIA-0535. (Washington, DC, various years.)

Energy Information Administration. Household Vehicles Energy Consumption. DOE/EIA-0464. (Washington, DC, various years.)

Energy Information Administration. International Energy Annual. DOE/EIA-0121. (Washington, DC, various years.)

Energy Information Administration. International Energy Outlook 1995. DOE/EIA-0484(95). (Washington, DC, June 1995.)

Energy Information Administration. Manufacturing Energy Consumption Survey. DOE/EIA-0512. (Washington, DC, various years.)

Energy Information Administration. Monthly Energy Review. DOE/EIA-0035. (Washington, DC, various issues.)

Energy Information Administration. Natural Gas Annual. DOE/EIA-0131. (Washington, DC, various years.)

Energy Information Administration. Natural Gas Monthly. DOE/EIA-0130. (Washington, DC, various issues.) 
Energy Information Administration. Petroleum Supply Annual. DOE/EIA-0340. (Washington, DC, various years.)

Energy Information Administration. Petroleum Supply Monthly. DOE/ELA-0109. (Washington, DC, various issues.)

Energy Information Administration. Quarterly Coal Report. DOE/EIA-0121. (Washington, DC, various issues.)

Energy Information Administration. Short-Term Energy Outlook. DOE/EIA-0202. (Washington, DC, various issues.)

Energy Information Administration. State Energy Data Report: Consumption Estimates. DOE/EIA-0214. (Washington, DC, various years.)

Franklin Associates, Ltd. Characterization of Municipal Solid Waste in the United States: 1992 Update. (Prepared for U.S. Environmental Protection Agency, July 1992.)

Franklin Associates, Ltd. Characterization of Municipal Solid Waste in the United States: 1994 Update. (Prepared for U.S. Environmental Protection Agency, July 1994.)

Freedonia Group Inc. Carbon Dioxide. Business Research Report B286. (Cleveland, OH, November 1991.)

Freedonia Group Inc. Carbon Dioxide. Industry Study 564. (Cleveland, OH, February 1994.)

Ghosh, S. "Methane Production from Farm Waste." Biogas Technology, Transfer, and Diffusion. Ed. M.M. EI Hawagi. (New York: Elsevier, 1984.) 665-668.

Goodger, E.M. Hydrocarbon Fuels: Production, Properties and Performance of Liquids and Gases. (New York, NY: John Wiley \& Sons, 1975.) 43.

Government Advisory Associates. Methane Recovery from Landfill Yearbook 1991-1992. (New York, NY, 1991.)

Griffin, R. " $\mathrm{CO}_{2}$ Release from Cement Production 19501985." Estimates of $\mathrm{CO}_{2}$ Emissions from Fossil Fuel Burning and Cement Manufacturing, Based on the United Nations Estimates and U.S. Bureau of Mines Cement Manufacturing Data. Ed. Gregg Marland et al. (Oak Ridge, TN, Oak Ridge National Laboratory, 1987.)

"Growth Maintains a Strong Pace." Chemical \& Engineering News 68. (June 19, 1989.) 39.

Grubb, M.J. “On Coefficients for Determining Greenhouse Gas Emissions From Fossil Fuel Production and Consumption." Royal Institute of International Affairs, Energy and Environmental Programme. (London, April 1989.)
Guerra, C.R., Kelton, K., and Nielsen, D.C. "Natural Gas Supplementation with Refinery Gases and Hydrogen." In Institute of Gas Technology, New Fuels and Advances in Combustion Technologies. (Chicago, $\mathrm{IL}$, June 1979.)

Gunnerson, C.G., and Stuckey, D.C. Integrated Resource Recovery: Anaerobic Digestion: Principles and Practices for Biogas System, World Bank Technical Paper.

Guthrie, V.B. Ed. Petroleum Products Handbook. (New York, NY: McGraw-Hill, 1960.)

Hadaller, O.J., and Momenthy, A.M. The Characteristics of Future Fuels, Part 1, "Conventional Jet Fuels." (Seattle, WA: Boeing Corp., September 1990.)

Hashimoto, A.G., Varel, V.H., and Chen, Y.R. “Ultimate Methane Yield from Beef Cattle Manure; Effect of Temperature, Ration Constituents, Antibiotics and Manure Age." Agricultural Wastes 3. (1981.) 241-256.

Hill, D.T. "Design of Digestion Systems for Maximum Methane Production." Transactions of the ASAE 25, 1. (1982.) 226-230.

Hill, D.T. "Methane Productivity of the Major Animal Types." Transactions of the ASAE 27, 2. (1984.) 530-540.

Holzappfel-Pschorn, A., and Seiler, W. "Methane Emission During a Cultivation Period from an Italian Rice Paddy." Journal of Geophysical Research 91, D11. (October 1986.) 11,803-11,814.

Hong, B.D., and Slatick, E.R. "Carbon Dioxide Emission Factors for Coal." Quarterly Coal Report, January-March 1994. 7.

Houghton, R.A., et al. "The Flux of Carbon from Terrestrial Ecosystems to the Atmosphere in 1980 Due to Changes in Land Use: Geographic Distribution of the Global Flux." Tellus 39. (1987.) 124.

Hunt, J.M. Petroleum Geochemistry and Geology. (San Francisco, CA: W.H. Freeman, 1979).

Intergovernmental Panel on Climate Change. Climate Change 1992: The Supplementary Report to the IPCC Scientific Assessment. (Cambridge, UK: Cambridge University Press, 1992.)

Intergovernmental Panel on Climate Change. Climate Change 1994: Radiative Forcing of Climate Change. (Cambridge, UK: Cambridge University Press, 1995.)

Intergovernmental Panel on Climate Change. Climate Change: The IPCC Scientific Assessment. (Cambridge, UK: Cambridge University Press, 1990.)

Intergovernmental Panel on Climate Change. IPCC Guidelines for National Greenhouse Gas Inventories. Vols. 1-4. (Paris, France, 1994-95.) 
Intergovernmental Panel on Climate Change. Methane and Nitrous Oxide Methods in National Emissions Inventories and Options for Control. Proceedings, Research for Man and Environment. (Netherlands, February 1993.)

International Trade Commission. Synthetic Organic Chemicals: United States Production and Trade. USITC Publication 2720. (Washington, DC, various years.)

Isakson, I.S.K., et al. "Radiative Forcing of Climate." In Intergovernmental Panel on Climate Change, Climate Change 1992: The Supplementary Report to the IPCC Assessment. (Cambridge, UK: Cambridge University Press, 1992.) 56.

Keeling, C.D., and Whorf, T.P. "Atmospheric $\mathrm{CO}_{2}$ Records from Sites in the SIO Air Sampling Network." (1993.) 18-28.

Kelafant, J.R., and Byer, C.M. "A Geologic Assessment of Natural Gas Coal Seams in the Central Appalachian Basin." Gas Research Institute Topical Report. GRI-88/ 0302. (1988.) $66 \mathrm{pp}$.

Kelafant, J.R., Wicks, D.E., and Kuuskraa, V.A. "A Geologic Assessment of Natural Gas Coal Seams in the Northern Appalachian Basin." Gas Research Institute Topical Report. GRI 88/0039. (1988.) 86 pp.

Kelso, B.S., Wicks, D.E., and Kuuskraa, V.A. "A Geologic Assessment of Natural Gas Coal Seams in the Fruitland Formation, San Juan Basin." Gas Research Institute Topical Report. GRI 88/034. (1988.) 56 pp.

Kirchgessner, D., Cowgill, R.M., Harrison, M., and Campbell, L.M. "Methods for Estimating Methane Emissions from the Domestic Natural Gas Industry." Presented at the 1995 Greenhouse Gas Emissions and Mitigation Research Symposium. (U.S. Environmental Protection Agency, National Risk Management Research Laboratory, Air Pollution Prevention Division, June 1995.)

Kirchgessner, D.A., Piccot, S.D., and Chadha, A. "Estimation of Methane Emissions from A Surface Coal Mine Using Open-Path FTIR Spectroscopy and Modeling Techniques." Chemosphere. (Special Methane Edition, 1993.)

Ko, M.K.W., Sze, N.D., Wang, W.C., Shia, G., Goldman, A., Murcray, F.J., Murcray, D.G., and Rinsland, C.P. "Atmospheric Sulfur Hexafluoride: Sources, Sinks, and Greenhouse Warming." Journal of Geophysical Research 98. 10,500 .

Kostick, D. "Soda Ash, Sodium Bicarbonate, and Sodium Sulfate." Mineral Facts and Problems. 1985 ed. (Washington, DC, 1985.) 843.

Kostick, D. "Sodium Compounds," Minerals Yearbook, 1987. (Washington, DC, 1987.) 795-801.
Kramlich, J.C., and Linak, W.P. "Nitrous Oxide Behavior in the Atmosphere, and in Combustion and Industrial Systems." Progress in Energy and Combustion Science 20. (1994.) 196.

Landau, C.W., and Bolich, P.K. "Methane Emissions from Louisiana First and Ratoon Crop." Soil Science 156. (1993.) 42-48.

Leutwyler, K. "No Global Warming?" Scientific American. (February 1994.) 24.

Li, C., Frolking, S., and Harriss, R. "Modeling Carbon Biogeochemistry in Agricultural Soils." Global Biogeochemical Cycles 8. (September 1994.)

Liss, W.E., et al. Variability of Natural Gas Composition in Select Major Metropolitan Areas of the United States. GRI92/0123. (Chicago, Gas Research Institute, October 1992.)

Mann, L.K. "Changes in Soil Carbon Storage After Cultivation." Soil Science 142, 5. (November 1986.) 279.

Mannsville Chemical Corporation. "Adipic Acid." Chemical Products Synopsis. (Asbury Park, NJ: June 1990.)

ManTech Environmental Technology, Inc. Impact of Conservation Tillage on Soil and Atmospheric Carbon in the Contiguous United States, PB92-113448, prepared for the Corvallis Environmental Research Laboratory, U.S. Environmental Protection Agency. (September 1991.)

Marland, G., and Rotty, R. "Carbon Dioxide Emissions from Fossil Fuels: A Procedure for Estimation and Results for 1950-1982." Tellus 36B. (1984.) 232-261.

Marland, G., et al. Estimates of $\mathrm{CO}_{2}$ Emissions from Fossil Fuel Burning and Cement Manufacturing, Based on the United Nations Energy Statistics and the U.S. Bureau of Mines Cement Manufacturing Data. (Oak Ridge, TN, Oak Ridge National Laboratory, 1989.)

Marland, G., and Pippin, A. "United States Emissions of Carbon Dioxide to the Earth's Atmosphere by Economic Activity." Energy Systems and Policy 14, 4. (1990.) 319-336.

Martel, C.R., and Angelo, L.C. "Hydrogen Content as a Measure of the Combustion Performance of Hydrocarbon Fuels." Current Research in Petroleum Fuels I. (New York, NY: MSS Information Corporation, 1977.)

Martin, S.W. "Petroleum Coke." Petroleum Processing Handbook. Ed. Virgil Guthrie. (New York, NY: McGrawHill, 1960.) 14-15.

Matthews, E., and Fung, I. "Methane Emissions from Natural Wetlands: Global Distribution, Area, and Environmental Characteristics." Global Biogeochemical Cycles 1. (March 1987.) 
Matthews, E., Fung, I., and Lerner, J. "Methane Emission from Rice Cultivation: Geographic and Seasonal Distribution of Cultivated Areas and Emissions." Global Biogeochemical Cycles 5, 1. (March 1991.) 10.

McFall, K.S., Wicks, D.E., and Kuuskraa, V.A. "A Geologic Assessment of Natural Gas Coal Seams in the Warrior Basin, Alabama." Gas Research Institute Topical Report. GRI-88/0272. (1986.) 80 pp.

McFall, K.S., et al. "A Geologic Assessment of Natural Gas Coal Seams in the Piceance Basin, Colorado." Gas Research Institute Topical Report. GRI-87/0060. (1986.) 76 pp.

Meyers, R.A., ed. Encyclopedia of Physical Science and Technology. Vol. 6 (Orlando, FL: Academic Press.) 275.

Morris, G.R. "Anaerobic Fermentation of Animal Wastes: A Kinetic and Empirical Design Fermentation." Master's thesis, Cornell University, 1976.

Mosier, A.R. "Nitrous Oxide Emissions from Agricultural Soils." International IPCC Workshop Proceedings: Methane and Nitrous Oxide, Methods in National Emissions Inventories and Options for Control Ed. A.R. van Amstel. (Bilthoven, Netherlands: RIVM, 1993.) 277.

Mosier, A.R., Parton, W.J., and Hutchinson, G.L. "Modelling Nitrous Oxide Evolution from Cropped and Native Soils." Ecol. Bulletin 35. (1983.) 229-241.

Mosier, A., and Schimel, D. "Influence of Agricultural Nitrogen on Atmospheric Methane and Nitrous Oxide." Chemistry \& Industry 2. (December 1991.) 875.

Mosier, A., et al. "Methane and Nitrous Oxide Fluxes in Native, Fertilized, and Cultivated Grasslands." Nature 350. (March 28, 1991.) 330-332.

Mroz, T.H., Ryan, J.G., and Bryer, C.W. Methane Recovery from Coalbeds: A Potential Energy Source. Report prepared for U.S. Department of Energy. DOE/METC/ 83-76. (October 1983.) $458 \mathrm{pp}$.

Nagy, B., and Columbo, U., Eds. Fundamental Aspects of Petroleum Chemistry. (New York, NY: Elsevier Publishing, 1967.) 1-5.

National Institute of Petroleum and Energy Research. Motor Gasoline, Summer, and Motor Gasoline, Winter. (1984-1994.)

National Research Council. Rethinking the Ozone Problem in Urban and Regional Air Pollution. (Washington, DC: National Academy Press, 1991.) 1-29.

Neue, H.H., and Scharpenseel, H.W. Gaseous Products of Decomposition of Organic Matter and Rice. (Los Banos, Philippines, 1984.)
Oak Ridge National Laboratory. Transportation Energy Data Book. (Oak Ridge, TN, various years.)

Oak Ridge National Laboratory. Carbon Dioxide Information Analysis Center. Trends 91-A Compendium of Data on Global Change. ORNL/CDIAC-46 No. 3746. (Oak Ridge, TN, December 1991.)

Organization for Economic Cooperation and Development. Estimation of Greenhouse Gas Emissions and Sinks. (Final Report.) (Paris, France, August 1991.)

Ozone Depletion Online Today, "DuPont Set to Expand Markets for Ozone-Safe HFC-152a Product." (Alexandria, VA, June 9, 1995.)

Pacey, J., Thorneloe, S.A., and Dorne, M. "Methane Recovery From Landfills and an Overview of EPA's Research Program for Landfill Gas Utilization." Presented at the 1995 Greenhouse Gas Emissions and Mitigation Research Symposium, U.S. Environmental Protection Agency. (Washington, DC, June 27-29, 1995.)

Parson, E.A., and Greene, O. "The Complex Chemistry of the International Ozone Agreements." Environment 37, No. 2. (March 1995.) 21.

Piccot, S.D., Masemore, S.S., Ringler, E., and Kirchgessner, D.A. "Developing Improved Methane Emission Estimates for Coal Mining Operations." Presented at the 1995 Greenhouse Gas Emissions and Mitigation Research Symposium. (U.S. Environmental Protection Agency, June 27-29, 1995.)

Prather, M., et al. "Other Trace Gases and Atmospheric Chemistry." Intergovernmental Panel on Climate Change. Climate Change 1994: Radiative Forcing of Climate Change. (Cambridge, UK: Cambridge University Press, 1995.)

Radian Corporation. Global Emissions of Carbon Dioxide from Petroleum Sources. Report prepared for the American Petroleum Institute. (Research Triangle Park, NC, July 1991.)

Radian Corporation. Global Emissions of Methane from Petroleum Sources. Report prepared for the American Petroleum Institute. (Research Triangle Park, NC, February 1992.)

Radian Corporation. Methane Emissions from Petroleum Production. (Research Triangle Park, NC, 1992.)

Radian Corporation. Nitrous Oxide Emissions from Adipic Acid Manufacturing. Final Report prepared for U.S. Environmental Protection Agency, Office of Research and Development. (Research Triangle Park, NC, January 1992.)

Railroad Commission of Texas. Annual Summaries of Texas Natural Gas. (Various years.) 
Reimer, R.A., Parrett, R.A., and Slaten, C.S. Abatement of $\mathrm{N}_{2} \mathrm{O}$ Emissions Produced in Adipic Acid, Proceedings of the 5 th International Workshop on Nitrous Oxide Emissions. (Tsukuba, Japan, July 1992.)

Reisch, M. "Top 50 Chemicals Production Resumed Growth Last Year." Chemical and Engineering News 69, 14. (April 8, 1991.) 13-16.

Reisch, M. "Top 50 Chemicals Production Stagnated Last Year." Chemical and Engineering News 70, 15. (April 13, 1992.) 16-19.

Rhodes, A.K. "U.S. Refiners Scramble To Meet Reformulated Gasoline Mandate." Oil and Gas Joumal. (January 27, 1992.)

Ringen, S., Lanum, J., and Miknis, F.P. "Calculating Heating Values from Elemental Compositions of Fossil Fuels." Fuel 58. (January 1979.) 69.

Rose, J.W., and Cooper, J.R. Technical Data on Fuel. The British National Committee, World Energy Conference, London, England. (1977.)

Safley, L.M., Casada, M.E., Woodbury, J., and Roos, K.F. Global Methane Emissions From Livestock and Poultry Manure. EPA/400/1-91/048. (Washington, DC, U.S. Environmental Protection Agency, Office of Air and Radiation, February 1992.)

Salthouse, R. Making Clean Gasoline. (Logistics Management Institute, September 1992.)

Sampson, R.N., and Winnett, S.M. "Trees, Forests, and Carbon." Forests and Global Change, Vol. 1. (Washington, DC, 1992.) 44.

Sass, R.L., Fisher, F.M., and Harcombe, P.A. "Methane Production and Emission in a Texas Rice Field." Global Biogeochemical Cycles 4, 1. (March 1990.) 47-68.

Sass, R., Fisher, F., Lewis, S., Jund, M., and Turner, F. "Methane Emissions from Rice Fields: Effect of Soil Properties." Global Biogeochemical Cycles 8. (1994.) 135.

Sass, R.L., Fisher, F.M., and Wang, Y.B. "Methane Emissions from Rice Fields: The Effect of Floodwater Management." Global Biogeochemical Cycles 6. (1992.) 249262.

Schlesinger, W.H. "Changes in Soil Carbon Storage and Associated Properties with Disturbance and Recovery." The Changing Carbon Cycle: A Global Analysis. Ed. J. Trabalka and D. Riechle. (New York: Springer-Verlag, 1986.)

Schmidt, Paul F. Fuel Oil Manual. (New York: Industrial Press, Inc., 1969.)
Schutz, H., Seiler, W., and Conrad, R. "Processes Involved in Formation and Emissions of Methane in Rice Paddies." Biogeochemistry 7. (1989.) 33-53.

Science Applications International Corporation. Analysis of the Relationship Between the Heat and Carbon Content of U.S. Fuels: Final Task Report. Report prepared for Energy Information Administration, Office of Coal, Nuclear, Electric, and Alternate Fuels. (Washington, DC, 1992.)

Searls, J.P. "Sodium Compounds," Minerals Yearbook, 1984. (Washington, DC: 1984.) 839-845.

Seiler, W., and Crutzen, P. "Estimates of Gross and Net Fluxes of Carbon Between the Biosphere and the Atmosphere from Biomass Burning." Climatic Change 2. (1980.)

Shine, K.P., Fouquart, Y., Ramaswamy, V., Solomon, S., and Srinivasan, J. "Radiative Forcing." Climate Change 1994: Radiative Forcing of Climate Change. (Cambridge, UK: Cambridge University Press, 1995.) 177.

Spicer, C.W., Holdren, M.W., Smith, D.L., Hughes, D.P., and Smith, M.D. "Chemical Composition of Exhaust From Aircraft Turbine Engines." Journal of Engineering for Gas Turbines and Power 114. (January 1992.) 111-117.

Steudler, P.A., et al. "Influence of Nitrogen Fertilization on Methane Uptake in Temperate Forest Soils." Nature 341. (September 28, 1989.) 314-315.

Stevens, W.R., III. Abatement of Nitrous Oxide Emissions Produced in the Adipic Acid Industry. White House Conference on Global Climate Change, Nitrous Oxide Workshop. (Mimeo, The DuPont Company, Wilmington, $\mathrm{DE}$, June 11, 1993.)

Strehler, A., and Stutzle, W. "Biomass Residues." Biomass: Regenerable Energy Ed. D.O. Hall and R.P. Overend. (Chichester, UK: John Wiley and Sons, 1987.) 85.

Summers, R., and Bousfield S. "A Detailed Study of Piggery Waste Anaerobic Digestion." Agricultural Wastes 2. (1980.) 61-78.

"Survey of State Agencies." World Oil. (February, various years.)

Svenson, B.H., and Rosswell, T. "In Situ Methane Production from Acid Peat in Plant Communities with Different Moisture Regimes in a Subarctic Mire." Oikos 43. (1984.) 341-350.

Takeshita, M., and Soud, H. IEA Coal Research. FGD Performance and Experience on Coal-fired Plants. (London, England, July 1993.) 
Tennessee Valley Authority, National Fertilizer and Environmental Research Center. Commercial Fertilizers (Including Fertilizer Use by Class). (Muscle Shoals, AL, 1986-1993.)

Thiemens, M., and Trogler, W. "Nylon Production: An Unknown Source of Atmospheric Nitrous Oxide." Science 251. (February 22, 1991.) 932-934.

Thorneloe, S.A. "Landfill Gas Recovery/UtilizationOptions and Economics." Presented at the Sixteenth Annual Conference by the Institute of Gas Technology on Energy From Biomass and Wastes, Orlando, FL, March 5, 1992.

Thorneloe, S.A., Doorn, M.R.J., Stefanski, L.A., Barlaz, M.A., Peer, R.L., and Epperson, D.L. "Estimate of Methane Emissions from U.S. Landfills." Prepared for U.S. Environmental Protection Agency, Office of Research and Development. In departmental review. (April 1994.)

"Top 50 Chemicals Production Rose Modestly Last Year." Chemical and Engineering News. (April 11, 1994.) $12-13$.

Trevits, M.A., Finfinger, G.L., and LaScola, J.C. "Evaluation of U.S. Coal Mine Emissions." Society for Mining, Metallurgy and Exploration, Proceedings of the Fifth U.S. Mine Ventilation Symposium. (Littlejohn, 1991.)

Turner, D.P., Lee, J.L., Koerper, G.J., and Barker, J.R., Eds. The Forest Sector Carbon Budget of the United States: Carbon Pools and Flux under Alternative Policy Options. EPA/600/3-93/093. (Washington, DC: U.S. Environmental Protection Agency, Office of Research and Development, May 1993.)

United Nations. "Report of the Intergovernmental Negotiating Committee for a Framework on Convention on Climate Change on the Work of the Second Part of Its Fifth Session, Held at New York From 30 April to 9 May 1992." UN Document A/AC.237/18, Part II. (May 15, 1992.)

U.S. Department of Agriculture, Crop Reporting Board, Statistical Reporting Service. Commercial Fertilizers. $\mathrm{SpCr}$ 7. (Washington, DC, various years.)

U.S. Department of Agriculture, National Agricultural Statistics Service, Livestock, Dairy, and Poultry Branch. Cattle: Final Estimates, Sheep and Goats: Final Estimates, and Hogs and Pigs: Final Estimates. (Washington, DC, various years.)

U.S. Department of Agriculture, National Agricultural Statistics Service. Crop Production. (Washington, DC, various years.)
U.S. Department of Agriculture, Soil Conservation Service. 1991 Update of National Resources Inventory Wetlands Data for Non-Federal Rural Lands. (Washington, DC, not dated.)

U.S. Department of Agriculture, Soil Conservation Service. Summary Report: 1992 National Resources Inventory. (Washington, DC, July 1994.)

U.S. Department of Commerce, Bureau of the Census. Census of Agriculture. 1982, 1987, and 1992.

U.S. Department of Commerce, Bureau of the Census. Current Industrial Reports: Annual Report on Fertilizer Materials. MA28B. (Washington, DC, 1992.)

U.S. Department of Commerce, Bureau of the Census. "Industrial Gases." Current Industrial Reports. (Washington, DC.)

U.S. Department of Commerce, Bureau of the Census. Census of Agriculture, United States Summary and State Data. Vol. 1, "Geographic Area Series," Part 51. (Washington, DC, 1982, 1987, and 1992.)

U.S. Department of Commerce, National Bureau of Standards. Thermal Properties of Petroleum Products, Miscellaneous Publication No. 97. (Washington, DC, 1929.)

U.S. Department of Energy. An Evaluation of the Relationship Between the Production and Use of Energy and Atmospheric Methane Emissions. DOE/NBB-0088P. (Washington, DC, April 1990.)

U.S. Department of Energy. Atmospheric Carbon Dioxide and the Global Carbon Cycle. DOE/ER-0239. Ed. J.R. Trabalka. (Washington, DC, 1985.)

U.S. Department of Energy. Compliance Assessment of the Portsmouth Gaseous Diffusion Plant. DOE/EH-0144. (Washington, DC, April 1990.)

U.S. Department of Energy. Energy Technology Characterizations Handbook: Environmental Pollution and Control Factors. Third Edition, DOE/EP-0093. (Washington, DC, March 1983.)

U.S. Department of Energy. Limiting Net Greenhouse Gas Emissions in the United States. Volume II. DOE/PE-0101. Ed. R.A. Bradley, E.C. Watts, and E.R. Williams. (Washington, DC, September 1991.)

U.S. Department of Energy. The Climate Change Action Plan: Technical Supplement. DOE/PO-0011. (Washington, DC, March 1994.)

U.S. Department of Energy. Tiger Team Assessment of the Paducah Gaseous Diffusion Plant. DOE/EH-0145 (draft). (Washington, DC, July 1990.) 
U.S. Department of Interior, Bureau of Mines. Cement Annual Report. (Washington, DC, various years.)

U.S. Department of Interior, Bureau of Mines. Crushed Stone Annual Report. (Washington, DC, various years.)

U.S. Department of Interior, Bureau of Mines. Minerals Commodity Summaries. (Washington, DC, various years.)

U.S. Department of Interior, Bureau of Mines. Minerals Yearbook. (Washington, DC, various years.)

U.S. Department of Interior, Bureau of Mines. Soda Ash Annual Report. (Washington, DC, various years.)

U.S. Department of State. National Action Plan for Global Climate Change. Publication 10026. (Washington, DC, December 1992.)

U.S. Department of Transportation, Federal Highway Administration. Highway Statistics. (Washington, DC, various years.)

U.S. Environmental Protection Agency. 1992 Toxics Release Inventory: Public Data Release. EPA-745-R-94-001. (Washington, DC, April 1994.)

U.S. Environmental Protection Agency. 1993 Toxics Release Inventory: Public Data Release. (Washington, DC, March 1995.)

U.S. Environmental Protection Agency. Compilation of Air Pollutant Emission Factors. AP-42 Supplement D. (Research Triangle Park, NC, September 1991.)

U.S. Environmental Protection Agency. Federal Register. Vol. 53, No. 156. (August 12, 1988.) 30599.

U.S. Environmental Protection Agency. Inventory of U.S. Greenhouse Gas Emissions and Sinks: 1990-1993. EPA 230-R-94-014. (Washington, DC, September 1994.)

U.S. Environmental Protection Agency. National Air Pollutant Emission Trends 1900-1993. EPA-454/R-94-027.

(Research Triangle Park, NC, October 1994.)

U.S. Environmental Protection Agency. The Forest Sector Carbon Budget of the United States: Carbon Pools and Flux Under Alternative Policy Options, EPA/600/3-93/093. (Washington, DC, May 1993.)

U.S. Environmental Protection Agency, Environmental Research Laboratory. The Impact of Conservation Tillage Use on Soil and Atmospheric Carbon in the Contiguous United States. EPA/600/3-91/056. (Corvallis, OR, November 1991.)

U.S. Environmental Protection Agency, Municipal Solid and Industrial Solid Waste Division, Office of Solid
Waste. Characterization of Municipal Solid Waste in The United States. EPA/530-R-92-019. (Washington, DC, July 1992.)

U.S. Environmental Protection Agency, Office of Air and Radiation. Anthropogenic Methane Emissions in the United States: Estimates for 1990. Report to Congress. Ed. Kathleen Hogan. (Washington, DC, April 1993.)

U.S. Environmental Protection Agency, Office of Air and Radiation. Methane Emissions From Coal MiningIssues and Opportunities for Reduction. EPA/400/990/008. (Washington, DC, September 1990.)

U.S. Environmental Protection Agency, Office of Air and Radiation. Sustainable Rice Productivity and Methane Reduction Research Plan. Ed. Barbara Braatz and Kathleen Hogan. (Washington, DC, September 1991.)

U.S. Environmental Protection Agency, Office of Air Quality Planning and Standards. National Air Quality and Emissions Trends Report, 1992. (Research Triangle Park, NC, October 1993.)

U.S. Environmental Protection Agency, Office of Air Quality Planning and Standards. National Air Pollutant Emissions Estimates 1940-1990. EPA-450/4-91-026. (Research Triangle Park, NC, November 1991.)

U.S. Environmental Protection Agency, Office of Air Quality Planning and Standards. National Air Pollutant Emission Estimates 1980-1991. EPA-454/R-92-013. (Research Triangle Park, NC, October 1992.)

U.S. Environmental Protection Agency, Office of Policy, Planning, and Evaluation. Policy Options for Stabilizing Global Climate. Draft Report to Congress. (Washington, DC, February 1989.)

U.S. Environmental Protection Agency, Office of Research and Development. The Forest Sector Carbon Budget of the United States: Carbon Pools and Flux Under Alternative Policy Options. EPA/600/3-93/093. (Washington, DC, May 1993.)

Vernon, J.L. IEA Coal Research. Market Impacts of Sulphur Control: The Consequences for Coal, IEACR/18. (London, England, October 1989.)

Wassmann, R., Papen, H., and Rennenberg, H. "Methane Emissions from Rice Paddies and Possible Mitigation Strategies." Chemosphere 26. (1993.) 201-217.

World Oil. Annual survey of State agencies. (February issue, various years.)

Wuebbles, D.J., and Edmonds, J. Primer on Greenhouse Gases. (Chelsea, MI: Lewis Publishers, 1991.) 


\section{Glossary}

Aerobic decomposition: The breakdown of a molecule into simpler molecules or atoms by microorganisms under favorable conditions of oxygenation.

Airshed: An area or region defined by settlement patterns or geology that results in discrete atmospheric conditions.

Albedo: The fraction of incident light or electromagnetic radiation that is reflected by a surface or body. See planetary albedo.

Anaerobic decomposition: The breakdown of molecules into simpler molecules or atoms by microorganisms that can survive in the partial or complete absence of oxygen.

Anode: A positive electrode, as in a battery, radio tube, etc.

Anthracite: A hard, black, lustrous coal containing a high percentage of fixed carbon and a low percentage of volatile matter. Often referred to as hard coal.

Anthropogenic: Human made. Usually used in the context of emissions that are produced as the result of human activities.

Asphalt: A dark-brown to black cement-like material obtained by petroleum processing, containing bitumens as the predominant constituents. Includes crude asphalt as well as the following finished products: cements, the asphalt content of emulsions (exclusive of water), and petroleum distillates blended with asphalt to make cutback asphalts.

Aviation gasoline: All special grades of gasoline for use in aviation reciprocating engines. Excludes blending components, which are blended or compounded into finished aviation gasoline.

Balancing item: A measurement of the difference between the reported amount of natural gas produced and the amount consumed.

Biofuels: Wood, waste, and alcohol fuels.

Biogas: The gas produced from the anaerobic decomposition of organic material in a landfill.

Biogenic: Produced by the actions of living organisms.
Biomass: The total dry organic matter or stored energy content of living organisms that is present at a specific time in a defined unit of the Earth's surface.

Biosphere: The portion of the Earth and its atmosphere that can support life. The part of the global carbon cycle that includes living organisms and biogenic organic matter.

Bituminous coal: A dense, black, soft coal, often with well-defined bands of bright and dull material. The most common coal, with moisture content usually less than 20 percent. Used for generating electricity, making coke, and space heating.

Bromofluorocarbons (halons): Inert, nontoxic chemicals that have at least one bromine atom in their chemical makeup. They evaporate without leaving a residue and are used in fire extinguishing systems, especially for large computer installations.

Bunker fuel: Fuel supplied to ships and aircraft in international transportation, irrespective of the flag of the carrier, consisting primarily of residual fuel oil for ships and distillate and jet fuel oils for aircraft.

Calcination: A process in which a material is heated to a high temperature without fusing, so that hydrates, carbonates, or other compounds are decomposed and the volatile material is expelled.

Calcium sulfate: A white crystalline salt, insoluble in water. Used in Keene's cement, in pigments, as a paper filler, and as a drying agent.

Calcium sulfite: A white powder, soluble in dilute sulfuric acid. Used in the sulfite process for the manufacture of wood pulp.

Carbon black: An amorphous form of carbon, produced commercially by thermal or oxidative decomposition of hydrocarbons and used principally in rubber goods, pigments, and printer's ink.

Carbon budget: The balance of the exchanges (incomes and losses) of carbon between carbon reservoirs (e.g., atmosphere and biosphere) in the carbon cycle.

Carbon cycle: All carbon reservoirs and exchanges of carbon from reservoir to reservoir by various chemical, 
physical, geological, and biological processes. Usually thought of as a series of the four main reservoirs of carbon interconnected by pathways of exchange. The four reservoirs, regions of the Earth in which carbon behaves in a systematic manner, are the atmosphere, terrestrial biosphere (usually includes freshwater systems), oceans, and sediments (includes fossil fuels). Each of these global reservoirs may be subdivided into smaller pools, ranging in size from individual communities or ecosystems to the total of all living organisms (biota).

Carbon sink: A pool (reservoir) that absorbs or takes up released carbon from another part of the carbon cycle.

Chlorofluorocarbons (CFCs): A family of inert, nontoxic, easily liquefied chemicals used in refrigeration, air conditioning, packaging, and insulation, or as solvents or aerosol propellants.

Clinker: Powdered cement, produced by heating a properly proportioned mixture of finely ground raw materials (calcium carbonate, silica, alumina, and iron oxide) in a kiln to a temperature of about $2,700^{\circ} \mathrm{F}$.

Cloud condensation nuclei: Aerosol particles that provide a platform for the condensation of water vapor, resulting in clouds with higher droplet concentrations and increased albedo.

Coal coke: A hard, porous product made by baking bituminous coal in ovens at temperatures as high as $2,000^{\circ} \mathrm{F}$. Used both as a fuel and as a reducing agent in blast furnaces. The term "coal coke" is used instead of "coke" to distinguish it from petroleum coke.

Coalbed methane: Methane produced from coalbeds in the same way that natural gas is produced from other strata. See methane.

Criteria pollutant: A pollutant determined to be hazardous to human health and regulated under EPA's National Ambient Air Quality Standards. The 1970 amendments to the Clean Air Act require EPA to describe the health and welfare impacts of a pollutant as the "criteria" for inclusion in the regulatory regime.

Cultivar: A horticulturally or agriculturally derived variety of a plant.

Deforestation: The removal of forest stands by cutting and burning to provide land for agricultural purposes, residential or industrial building sites, roads, etc., or by harvesting the trees for building materials or fuel.

Degradable organic carbon: The portion of organic carbon, present in such solid waste as paper, food waste, and yard waste, that is susceptible to biochemical decomposition.
Desulfurization: The removal of sulfur, as from molten metals, petroleum oil, or flue gases.

Distillate fuel: A general classification for the petroleum fractions produced in conventional distillation operations. Included are products known as No. 1, No. 2, and No. 4 fuel oils and No. 1, No. 2, and No. 4 diesel fuels. Used primarily for space heating, on- and offhighway diesel engine fuel (including railroad engine fuel and fuel for agricultural machinery), and electric power generation.

Efflux: An outward flow.

Enteric fermentation: A digestive process by which carbohydrates are broken down by microorganisms into simple molecules for absorption into the bloodstream of an animal.

Ethylene dichloride: A colorless, oily liquid used as a solvent and fumigant for organic synthesis, and for ore flotation.

Ethylene: An olefinic hydrocarbon recovered from refinery or petrochemical processes.

Facultative bacteria: Bacteria that grow equally well under aerobic and anaerobic conditions.

Flared natural gas: Natural gas burned in flares on the well site or at gas processing plants.

Flatus: Gas generated in the intestines or the stomach of an animal.

Flue gas desulfurization: Equipment used to remove sulfur oxides from the combustion gases of a boiler plant before discharge to the atmosphere. Also referred to as scrubbers. Chemicals such as lime are used as scrubbing media.

Fluidized-bed combustion: A method of burning particulate fuel, such as coal, in which the amount of air required for combustion far exceeds that found in conventional burners. The fuel particles are continually fed into a bed of mineral ash in the proportions of 1 part fuel to 200 parts ash, while a flow of air passes up through the bed, causing it to act like a turbulent fluid.

Fossil fuel: Any naturally occurring organic fuel formed in the Earth's crust, such as petroleum, coal, or natural gas.

Fugitive emissions: Unintended leaks of gas from the processing, transmission, and/or transportation of fossil fuels.

Gasification: A method for exploiting poor-quality coal and thin coal seams by burning the coal in place to produce combustible gas that can be collected and burned to generate power or processed into chemicals and fuels. 
Geothermal: Pertaining to heat within the Earth.

Global Warming Potential (GWP): The instantaneous radiative forcing that results from the addition of 1 kilogram of a gas to the atmosphere, relative to that of 1 kilogram of carbon dioxide.

Greenhouse effect: A popular term used to describe the roles of water vapor, carbon dioxide, and other gases in keeping the Earth's surface warmer than it would otherwise be. These radiatively active gases are relatively transparent to incoming shortwave radiation, but are relatively opaque to outgoing longwave radiation. The latter radiation, which would otherwise escape to space, is trapped by greenhouse gases within the lower levels of the atmosphere. The subsequent reradiation of some of the energy back to the Earth maintains higher surface temperatures than would occur if the gases were absent. There is concern that increasing concentrations of greenhouse gases, including carbon dioxide, methane, and chlorofluorocarbons, may enhance the greenhouse effect and cause global warming.

Greenhouse gases: Those gases, such as water vapor, carbon dioxide, tropospheric ozone, nitrous oxide, and methane, that are transparent to solar radiation but opaque to longwave radiation. Their action is similar to that of glass in a greenhouse.

Gypsum: The most common sulfate mineral. Used in wallboard.

Halons: See bromofluorocarbons.

Hydrocarbon: An organic chemical compound of hydrogen and carbon in either gaseous, liquid, or solid phase. The molecular structure of hydrocarbon compounds varies from the simple (e.g., methane, a constituent of natural gas) to the very heavy and very complex.

Hydrochlorofluorocarbons (HCFCs): Chemicals composed of one or more carbon atoms and varying numbers of hydrogen, chlorine, and fluorine atoms.

Hydrofluorocarbons (HFCs): Chemicals composed of one or two carbon atoms and varying numbers of hydrogen and fluorine atoms.

Hydroxyl radical $(\mathrm{OH})$ : An important chemical scavenger of many trace gases in the atmosphere that are greenhouse gases. Atmospheric concentrations of $\mathrm{OH}$ affect the atmospheric lifetimes of greenhouse gases, their abundance, and, ultimately, the effect they have on climate.

Jet fuel: Kerosene- and naphtha-type fuels for jet engines. Kerosene-type jet fuel is a kerosene-quality product used primarily for commercial turbojet and turboprop aircraft engines. Naphtha-type jet fuel is a fuel in the heavy naphtha range used primarily for military turbojet and turboprop aircraft engines.

Kerosene: $\mathrm{A}$ petroleum distillate that has a maximum distillation temperature of $401^{\circ} \mathrm{F}$ at the 10-percent recovery point, a final boiling point of $572^{\circ} \mathrm{F}$, and a minimum flash point of $100^{\circ} \mathrm{F}$. Used in space heaters, cookstoves, and water heaters, and suitable for use as an illuminant when burned in wick lamps.

Ketone-alcohol (cyclohexanol): An oily, colorless, hygroscopic liquid with a camphor-like odor. Used in soapmaking, dry cleaning, plasticizers, insecticides, and germicides.

Leachate: A liquid produced as water percolates through wastes, collecting contaminants.

Lignite: A brownish-black coal of low rank with high inherent moisture and volatile matter content, used almost exclusively for electric power generation. Also referred to as brown coal.

Liquefied petroleum gases (LPG): Ethane, ethylene, propane, propylene, normal butane, butylene, and isobutane produced at refineries or natural gas processing plants, including plants that fractionate new natural gas plant liquids.

Lubricant: A substance used to reduce friction between bearing surfaces or as a process material, either incorporated into other materials used as aids in manufacturing processes or as carriers of other materials. Petroleum lubricants may be produced either from distillates or residues. Other substances may be added to impart or improve useful properties. Does not include byproducts of lubricating oil from solvent extraction or tars derived from deasphalting. Lubricants include all grades of lubricating oils from spindle oil to cylinder oil and those used in greases. Lubricant categories are paraffinic and naphthenic.

Methane: A hydrocarbon gas $\left(\mathrm{CH}_{4}\right)$ that is the principal constituent of natural gas.

Methanogens: Bacteria that synthesize methane, requiring completely anaerobic conditions for growth.

Methanol: A light alcohol that can be used for gasoline blending. See oxygenate.

Methanotrophs: Bacteria that use methane as food and oxidize it into carbon dioxide.

Methyl chloroform (trichloroethane): An industrial chemical $\left(\mathrm{CH}_{3} \mathrm{CCl}_{3}\right)$ used as a solvent, aerosol propellant, and pesticide and for metal degreasing.

Methylene chloride: A colorless liquid, nonexplosive and practically nonflammable. Used as a refrigerant in 
centrifugal compressors, a solvent for organic materials, and a component in nonflammable paint removers.

Mole: The quantity of a compound or element that has a weight in grams numerically equal to its molecular weight. Also referred to as gram molecule or gram molecular weight.

Montreal Protocol: The Montreal Protocol on Substances that Deplete the Ozone Layer (1987). An international agreement, signed by most of the industrialized nations, to substantially reduce the use of chlorofluorocarbons (CFCs). Signed in January 1989, the original document called for a 50-percent reduction in CFC use by 1992 relative to 1986 levels. The subsequent London Agreement called for a complete elimination of CFC use by 2000 . The yet-to-be-ratified Copenhagen Agreement calls for a complete phaseout by January 1, 1996.

Motor gasoline: A complex mixture of relatively volatile hydrocarbons, with or without small quantities of additives, obtained by blending appropriate refinery streams to form a fuel suitable for use in spark-ignition engines. Motor gasoline includes both leaded and unleaded grades of finished gasoline, blending components, and gasohol.

Multiple cropping: A system of growing several crops on the same field in one year.

Naphtha: A generic term applied to a petroleum fraction with an approximate boiling range between 122 and $400^{\circ} \mathrm{F}$.

Natural gas: A mixture of hydrocarbons and small quantities of various nonhydrocarbons in the gaseous phase or in solution with crude oil in natural underground reservoirs.

Natural gas liquids (NGLs): Those hydrocarbons in natural gas that are separated as liquids from the gas. Includes natural gas plant liquids and lease condensate.

Nitrogen oxides $\left(\mathrm{NO}_{\mathrm{x}}\right)$ : Compounds of nitrogen and oxygen produced by the burning of fossil fuels.

Nonmethane volatile organic compounds (NMVOCs): Organic compounds, other than methane, that participate in atmospheric photochemical reactions.

Oxygenate: A substance which, when added to gasoline, increases the amount of oxygen in that gasoline blend. Includes fuel ethanol, methanol, and methyl tertiary butyl ether (MTBE).

Ozone: A molecule made up of three atoms of oxygen. Occurs naturally in the stratosphere and provides a protective layer shielding the Earth from harmful ultraviolet radiation. In the troposphere, it is a chemical oxidant, a greenhouse gas, and a major component of photochemical smog.

Ozone precursors: Chemical compounds, such as carbon monoxide, methane, nonmethane hydrocarbons, and nitrogen oxides, which in the presence of solar radiation react with other chemical compounds to form ozone.

Perfluorocarbons (PFCs): Chemicals composed of one or two carbon atoms and four to six fluorine atoms, containing no chlorine. PFCs have no commercial uses and are emitted as a byproduct of aluminum smelting.

Perfluoromethane: A compound $\left(\mathrm{CF}_{4}\right)$ emitted as a byproduct of aluminum smelting.

Petrochemical feedstock: Feedstock derived from petroleum, used principally for the manufacture of chemicals, synthetic rubber, and a variety of plastics. The categories reported are naphthas (endpoint less than $401^{\circ} \mathrm{F}$ ) and other oils (endpoint equal to or greater than $401^{\circ} \mathrm{F}$ ).

Petroleum: Hydrocarbon mixtures, including crude oil, lease condensate, natural gas, products of natural gas processing plants, refined products, semifinished products, and blending materials.

Petroleum coke: A residue that is the final product of the condensation process in cracking.

Photosynthesis: The manufacture by plants of carbohydrates and oxygen from carbon dioxide and water in the presence of chlorophyll, with sunlight as the energy source. Oxygen and water vapor are released in the process.

Pig iron: Crude, high-carbon iron produced by reduction of iron ore in a blast furnace.

Planetary albedo: The fraction of incident solar radiation that is reflected by the Earth-atmosphere system and returned to space, mostly by backscatter from clouds in the atmosphere.

Polyvinyl chloride (PVC): A polymer of vinyl chloride. Tasteless odorless, insoluble in most organic solvents. A member of the family vinyl resin, used in soft flexible films for food packaging and in molded rigid products such as pipes, fibers, upholstery, and bristles.

Radiative forcing: The extent to which injecting a unit of a greenhouse gas into the atmosphere raises global average temperature.

Radiatively active gases: Gases that absorb incoming solar radiation or outgoing infrared radiation, affecting the vertical temperature profile of the atmosphere. 
Redox potential: A measurement of the state of oxidation of a system.

Reflectivity: The ratio of the energy carried by a wave after reflection from a surface to its energy before reflection.

Renewable energy: Energy obtained from sources that are essentially inexhaustible (unlike, for example, the fossil fuels, of which there is a finite supply). Renewable sources of energy include wood, waste, geothermal, wind, photovoltaic, and solar thermal energy.

Residual fuel oil: The heavier oils that remain after the distillate fuel oils and lighter hydrocarbons are distilled away in refinery operations and that conform to ASTM Specifications D396 and D975. Included are No. 5, a residual fuel oil of medium viscosity; Navy Special, for use in steam-powered vessels in government service and in shore power plants; and No. 6, which includes Bunker $C$ fuel oil and is used for commercial and industrial heating, electricity generation, and to power ships. Imports of residual fuel oil include imported crude oil burned as fuel.

Sinter: A chemical sedimentary rock deposited by precipitation from mineral waters, especially siliceous sinter and calcareous sinter.

Sodium silicate: A grey-white powder soluble in alkali and water, insoluble in alcohol and acid. Used to fireproof textiles, in petroleum refining and corrugated paperboard manufacture, and as an egg preservative. Also referred to as liquid gas, silicate of soda, sodium metasilicate, soluble glass, and water glass.

Sodium tripolyphosphate: A white powder used for water softening and as a food additive and texturizer.

Still gas: Any form or mixture of gases produced in refineries by distillation, cracking, reforming, and other processes. Principal constituents are methane, ethane, ethylene, normal butane, butylene, propane, propylene, etc. Used as a refinery fuel and as a petrochemical feedstock.

Stratosphere: The region of the upper atmosphere extending from the tropopause ( 8 to 15 kilometers altitude) to about 50 kilometers. Its thermal structure, which is determined by its radiation balance, is generally very stable with low humidity.

Stripper well: A well that produces 60 million cubic feet of gas per day or less for a period of three consecutive months while producing at its maximum flow rate.
Styrene: A colorless, toxic liquid with a strong aromatic aroma. Insoluble in water, soluble in alcohol and ether; polymerizes rapidly; can become explosive. Used to make polymers and copolymers, polystyrene plastics, and rubber.

Subbituminous coal: A dull, black coal of rank intermediate between lignite and bituminous coal.

Sulfur dioxide: A toxic, irritating, colorless gas soluble in water, alcohol, and ether. Used as a chemical intermediate, in paper pulping and ore refining, and as a solvent.

Sulfur hexafluoride: A colorless gas soluble in alcohol and ether, slightly soluble in water. Used as a dielectric in electronics.

Sulfur oxides $\left(\mathrm{SO}_{\mathrm{x}}\right)$ : Compounds containing sulfur and oxygen, such as sulfur dioxide $\left(\mathrm{SO}_{2}\right)$ and sulfur trioxide $\left(\mathrm{SO}_{3}\right)$.

Troposphere: The inner layer of the atmosphere below about 15 kilometers, within which there is normally a steady decrease of temperature with increasing altitude. Nearly all clouds form and weather conditions manifest themselves within this region. Its thermal structure is caused primarily by the heating of the Earth's surface by solar radiation, followed by heat transfer through turbulent mixing and convection.

Volatile organic compounds (VOCs): Organic compounds that participate in atmospheric photochemical reactions.

Waxes: Solid or semisolid materials derived from petroleum distillates or residues. Light-colored, more or less translucent crystalline masses, slightly greasy to the touch, consisting of a mixture of solid hydrocarbons in which the paraffin series predominates. Included are all marketable waxes, whether crude scale or fully refined. Used primarily as industrial coating for surface protection.

Wetlands: Areas regularly saturated by surface or groundwater and subsequently characterized by a prevalence of vegetation adapted for life in saturatedsoil conditions.

Wood energy: Wood and wood products used as fuel, including roundwood (cordwood), limbwood, wood chips, bark, sawdust, forest residues, and charcoal. 